\title{
Olhar dos recursos e \\ do meio ambiente do estado de Sergipe
}

ORGANIZADORES

Inajá Francisco de Sousa Adnivia Santos Costa Monteiro Neuma Rubia Figueiredo Santana
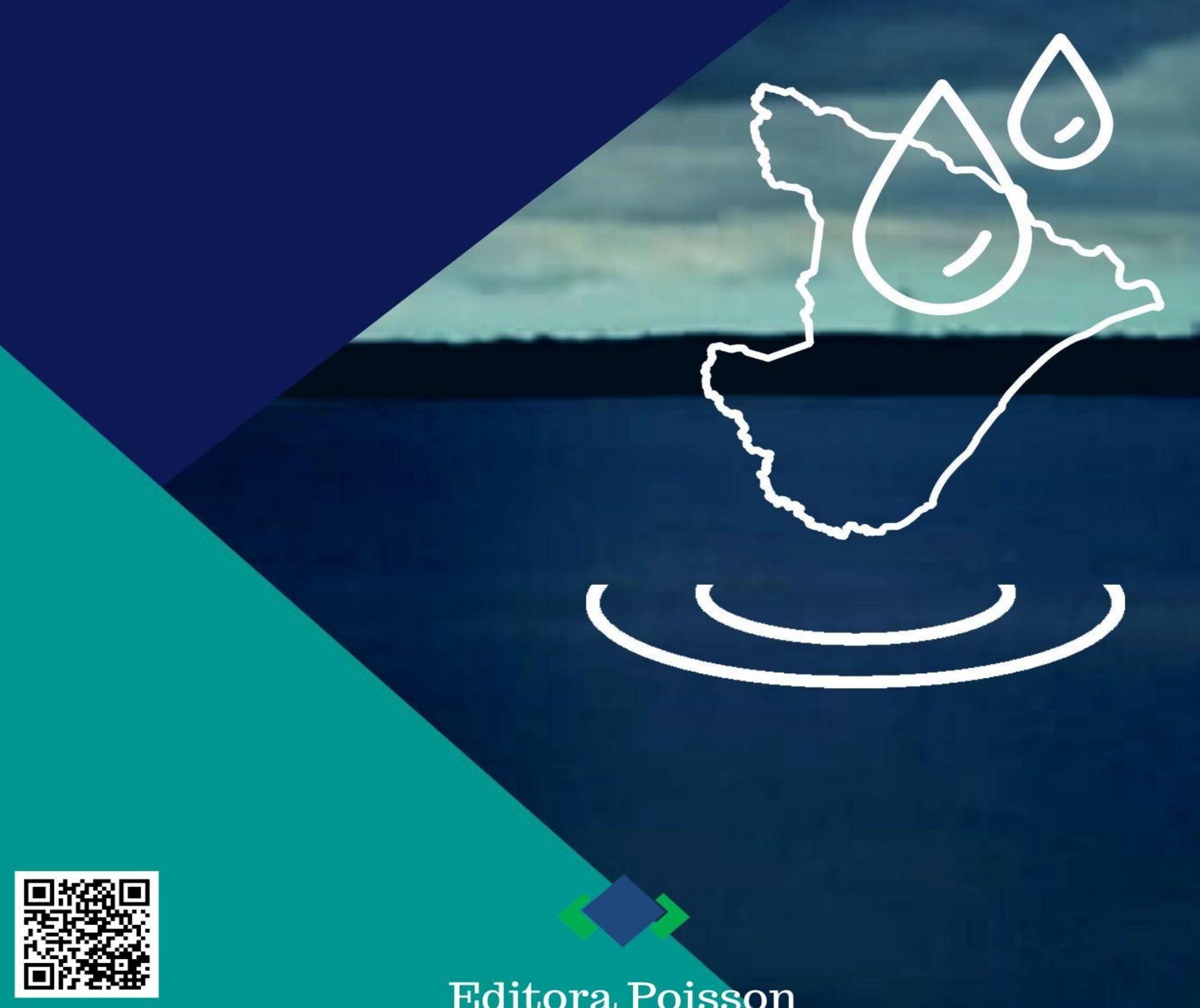


\title{
Organizadores:
}

Inajá Francisco de Sousa

Adnivia Santos Costa Monteiro

Neuma Rubia Figueiredo Santana

\section{Olhar dos recursos e do meio ambiente do estado de Sergipe}

\author{
1a Edição
}

Belo Horizonte

Poisson 


\section{Editor Chefe: Dr. Darly Fernando Andrade}

\section{Conselho Editorial}

Dr. Antônio Artur de Souza - Universidade Federal de Minas Gerais

Ms. Davilson Eduardo Andrade

Dra. Elizângela de Jesus Oliveira - Universidade Federal do Amazonas

Msc. Fabiane dos Santos

Dr. José Eduardo Ferreira Lopes - Universidade Federal de Uberlândia

Dr. Otaviano Francisco Neves - Pontifícia Universidade Católica de Minas Gerais

Dr. Luiz Cláudio de Lima - Universidade FUMEC

Dr. Nelson Ferreira Filho - Faculdades Kennedy

Ms. Valdiney Alves de Oliveira - Universidade Federal de Uberlândia

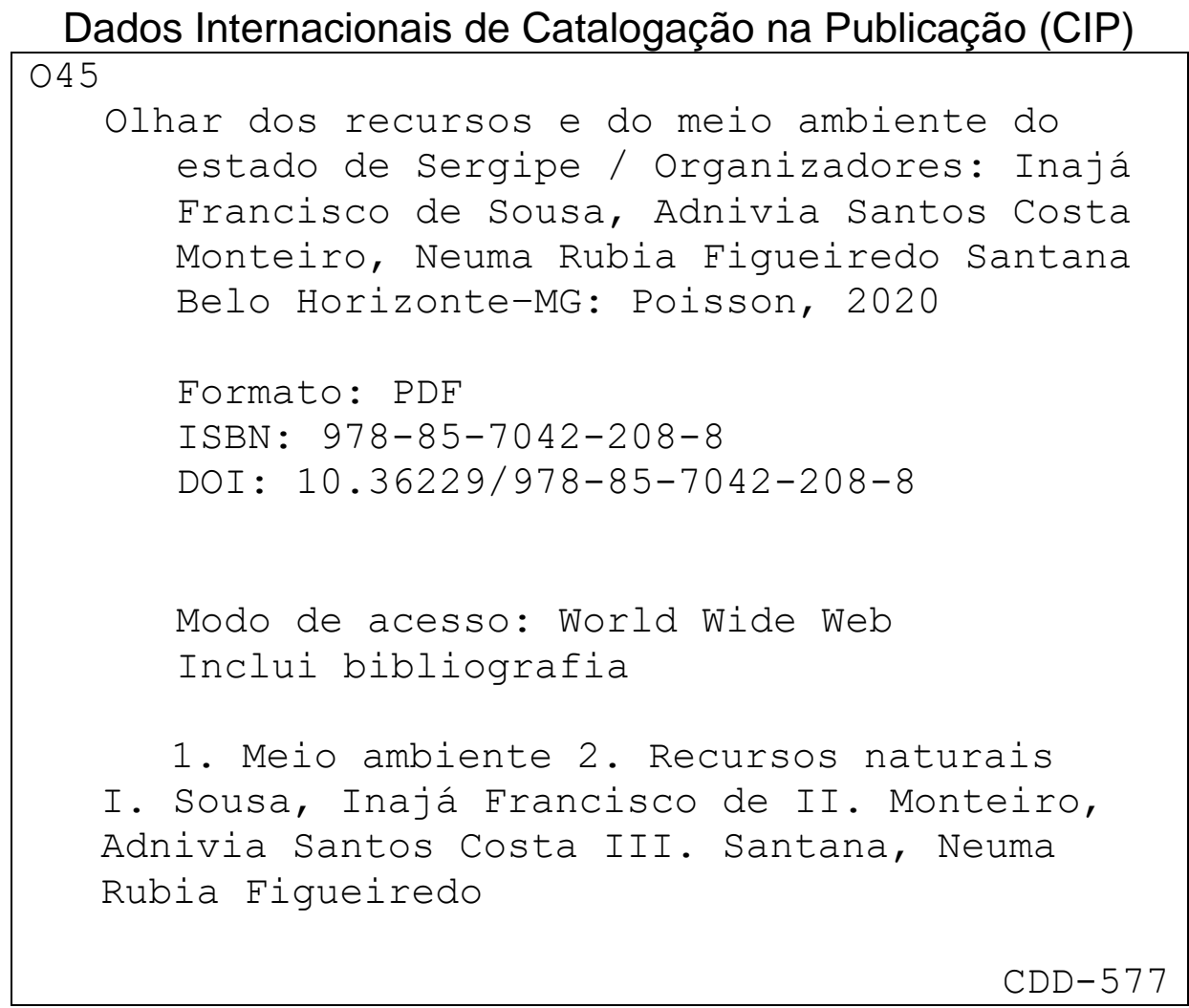

O conteúdo dos artigos e seus dados em sua forma, correção e confiabilidade são de responsabilidade exclusiva dos seus respectivos autores

www.poisson.com.br

contato@poisson.com.br 


\section{SUMÁRIO}

Capítulo 1: Estimativa dos componentes azul e verde da pegada hídrica da batata-doce no agreste sergipano 06

Rodolfo Rafael Andrade de Matos, Inajá Francisco de Sousa

DOI: 10.36229/978-85-7042-208-8.CAP.01

Capítulo 2: Análise microbiológica de cenoura e beterraba irrigadas com águas residuárias domésticas tratadas 20

Iasmine Louise de Almeida Dantas, Gregorio Guirado Faccioli, Alane Regina Rodrigues dos Santos, Luiz Ricardo Santana de Araújo

DOI: $10.36229 / 978-85-7042-208-8 . C A P .02$

Capítulo 3: Variações na qualidade da água e no estado trófico do Reservatório Macela no período de 2004 a 2014 34

Ivane Marcley Nascimento Sena, Adnívia Santos Costa Monteiro, José do Patrocínio Hora Alves DOI: $10.36229 / 978-85-7042-208-8 . C A P .03$

Capítulo 4: Análise jurídica e técnica dos procedimentos de outorga do uso da água na bacia hidrográfica do rio Japaratuba/SE. 48

Luiz Ricardo Santana de Araújo, Gregorio Guirado Faccioli, Alane Regina Rodrigues dos Santos, Iasmine Louise de Almeida Dantas

DOI: $10.36229 / 978-85-7042-208-8 . C A P .04$

Capítulo 5: Uso múltiplo da água no baixo São Francisco: A navegação e seus (des)dobramentos 60

Adriano Morais Araujo, Antenor de Oliveira Aguiar Netto

DOI: 10.36229/978-85-7042-208-8.CAP.05

Capítulo 6: Avaliação da qualidade da água do rio paripe, indiaroba-se, com emprego de indicadores quantitativos 73

Carlos Alexandre Borges Garcia, Cristina dos Santos Esteves, Marinoé Gonzaga da Silva, José Augusto Oliveira Junior, Silvânio Silvério Lopes da Costa

DOI: $10.36229 / 978-85-7042-208-8 . C A P .06$

Capítulo 7: Lógica fuzzy aplicada a predição da qualidade da água do reservatório da Macela-SE. 93

Igor Santos Silva, Maria Caroline Silva Mendonça, Helenice Leite Garcia, Silvânio Silvério Lopes da Costa, Carlos Alexandre Borges Garcia

DOI: 10.36229/978-85-7042-208-8.CAP.07 


\section{SUMÁRIO}

Capítulo 8: Caracterização da matéria orgânica dissolvida presente nas águas superficiais dos rios São Francisco e Jacaré utilizando fluorescência molecular 101

Roseane dos Santos Nascimento, Jeferson Alves de Alcântara, João Marcos de Jesus Sales, Igor Santos Silva, Silvânio Silvério Lopes da Costa, Adnívia Santos Costa Monteiro

DOI: $10.36229 / 978-85-7042-208-8 . C A P .08$

Capítulo 9: Modelagem hidrossedimentológica da bacia hidrográfica do rio Betume, Baixo São Francisco sergipano.

Antenor de Oliveira Aguiar Netto, Ricardo David Castillo Salazar, Clayton Moura de Carvalho, Marcela de Luna Freire Duarte

DOI: $10.36229 / 978-85-7042-208-8 . C A P .09$ 


\section{Capítulo 1}

Estimativa dos componentes azul e verde da pegada hídrica da batata-doce no agreste sergipano

\section{Rodolfo Rafael Andrade de Matos}

Inajá Francisco de Sousa

Resumo: Entre os diversos métodos de aproveitamento da água adotados pela humanidade, os recursos hídricos são mais utilizados na agricultura através do procedimento da irrigação, permitindo os cultivos agrícolas em espaços mais abrangente, sendo assim, capaz de atender a demanda por alimentos tanto para consumo humano quanto consumo animal. Este trabalho apresenta o conceito de Pegada Hídrica (Water Footprint) que é a quantidade de água direta e indireta usada na produção de um produto. A pegada hídrica é dividida em três componentes: verde, azul e cinza. 0 objetivo deste estudo foi determinar os valores da pegada hídrica dos componentes azul e verde para a produção da batata-doce através do método tradicional utilizando o software CROPWAT 8.1 durante os anos de 2010, 2011 e 2012. 0 trabalho foi desenvolvido no Perímetro de Irrigação Poção da Ribeira (PIPR) pertencente à Companhia de Desenvolvimento de Recursos Hídricos e Irrigação (COHIDRO), localizado nos municípios de Itabaiana e Campo do Brito em Sergipe. Os resultados obtidos evidenciaram que a Pegada Hídrica verde em 2010, 2011 e 2012, foi de $494,75\left(\mathrm{~m}^{3} /\right.$ ton), $672,13\left(\mathrm{~m}^{3} /\right.$ ton) e 402,81 ( $\mathrm{m}^{3} /$ ton) respectivamente. Já a Pegada Hídrica azul em 2010, 2011 e 2012 foi de 351,1 ( $\mathrm{m}^{3} /$ ton $), 448,4\left(\mathrm{~m}^{3} /\right.$ ton $)$ e $570,06\left(\mathrm{~m}^{3} /\right.$ ton $)$. Os resultados obtidos mostraram que há relação entre os índices médios de produtividade da cultura com um maior consumo de água refletindo em maior Pegada Hídrica, que há influência da precipitação na Pegada Hídrica da batata-doce e que não há relação direta entre os índices de produtividade com as variáveis meteorológicas utilizadas nos cálculos da Pegada Hídrica.

Palavras-chave: Necessidade Hídrica, Recursos Hídricos, Evapotranspiração, Pegada Hídrica. 


\section{INTRODUÇÃO}

Entre os diversos modos de uso da água adotados pela humanidade, a agricultura é a que mais utiliza deste recurso, os grandes projetos de irrigação transportam águas superficiais e subterrâneas para áreas mais distantes, permitindo cultivos agrícolas em espaços mais abrangentes, buscando atender a demanda de alimentos global para consumo humano e animal.

Porém, as reservas de água doce estão dispostas em quantidade limitada e grandes parcelas são comprometidas pela poluição, além da má distribuição geográfica que muitas vezes não corresponde a locais com grandes mananciais e concentrações demográficas. A dessalinização da água salgada é uma saída para a escassez, porém seu custo e os métodos de conversão inviabilizam seu uso em quantidade apropriada para culturas agrícolas.

Esse cenário impõe para agropecuária uma revisão nos modos de manejo da água voltados para a produção, buscando uma sustentabilidade no uso, acompanhando a oferta e demanda, reduzindo o desperdício e maximizando seu aproveitamento, evitando por fim o risco de comprometimento destas atividades com a escassez hídrica.

Nesse contexto, Arjen Y. Hoekstra definiu em 2002 o conceito de Pegada Hídrica, sendo "um indicador do uso da água que não considera apenas o seu uso direto por um consumidor ou produtor, mas também, seu uso indireto" (HOEKSTRA ET AL., 2011). A Pegada Hídrica (PH) é caracterizada como uma ferramenta no âmbito da gestão dos recursos hídricos que permite que tanto as iniciativas públicas como as iniciativas privadas, assim como a sociedade, saibam a quantidade de água necessária para desenvolver produtos ao longo de sistemas produtivos.

Desta maneira, é possível o envolvimento todas as partes a partir da quantificação da apropriação da água doce, contribuindo positivamente na criação de medidas de redução e mecanismos de compensação para os conflitos por água e na degradação de bacias hidrográficas em todo globo terrestre.

A Pegada Hídrica se divide em três categorias: a azul, sendo a água retirada de mananciais superficiais e subterrâneos que podem ser utilizadas para irrigação; a verde, no qual representa a água sob a forma líquida que entra nos mananciais através das chuvas; e a cinza, que é a quantidade de água necessária para diluir agentes poluidores nos corpos hídricos (GERBENS LEENES ET AL. 2009).

A redução da Pegada Hídrica é indispensável para garantir a sustentabilidade do recurso hídrico e pode ser alcançada através da promoção do aumento da eficiência de sua utilização no setor agropecuário, entre as sugestão para um melhor uso está o aproveitamento da água da chuva e melhorias nos sistemas de irrigação para o cultivo de grãos e para a limpeza das instalações, assim como, a sensibilização dos consumidores a respeito da quantidade de água utilizada na produção de determinados produtos.

O surgimento do conceito da Pegada Hídrica abriu um vasto potencial de possiblidades de investigação acerca da avaliação sobre a quantidade de água consumida na produção detectando o nível de sustentabilidade hídrica, ou seja, consumindo o necessário para não comprometer a subsistência do ecossistema, por ser um conceito recente, muitos estudos sobre sua aplicação estão em desenvolvimento.

Apesar desse problema, que atrapalha a comparação entre as pesquisas existentes, as equações desenvolvidas a partir do conceito de Pegada Hídrica facilitam as pesquisas acerca do consumo de água num determinado processo. Um trabalho a destacar-se é o de Albuquerque (2013), onde aplicou-se a PH na produção na cultura da cana-de-açúcar na região dos tabuleiros costeiros do Estado da Paraíba. Outro exemplo é o trabalho de Müller (2013), onde calculou-se a PH em todas as etapas de produção do biodiesel da soja.

No caso da agricultura, os cálculos podem ser elaborados para definir os valores de consumo baseados em culturas agrícolas, espaços para pecuária e pesca ou em áreas geográficas como bacias hidrográficas, perímetros irrigados ou territórios cuja delimitação foi política.

De acordo com Chapagain e Tickner (2012), a contabilização da pegada hídrica é uma excelente ferramenta de comunicação e bastante útil no processo de sensibilização em relação às questões mais generalizadas sobre os recursos hídricos.

Portanto, este estudo objetivou estimar e comparar os valores dos componentes azul e verde assim como relacionar os valores obtidos com os índices de produtividade médios da batata doce durante os anos de 2010, 2011 e 2012 em dois perímetros irrigados no Estado de Sergipe. 


\section{METODOLOGIA}

\subsection{CARACTERIZAÇÃO DA ÁREA DE ESTUDO}

O estudo foi realizado no Perímetro Irrigado Poção da Ribeira (PIPR), localizado no município de Itabaiana no Território Agreste Central do Estado de Sergipe. 0 perímetro (Figura 1) encontra-se a treze quilômetros da sede municipal de Itabaiana, cujas coordenadas geográficas são $10^{\circ} 42^{\prime \prime} \mathrm{S}$ e $37^{\circ} 24^{\prime} \mathrm{W}$, a cinquenta quilômetros de Aracaju, capital sergipana. O espaço é administrado pela Companhia de Desenvolvimento de Recursos Hídricos e Irrigação de Sergipe (COHIDRO, 2012).

Segundo informações da COHIDRO (2012), o Perímetro Irrigado Poção da Ribeira possui área de 1.970 hectares, sendo 1.100 deles irrigáveis, divididos em 466 lotes irrigados cujas áreas individuais não superam cinco hectares de área. 0 método predominante de irrigação é a aspersão convencional.

A estrutura física do PIPR conforme a COHIDRO (2012) consiste em uma barragem de terra no rio Traíras com 26 metros de altura, 500 metros de comprimento de crista, formando um reservatório de acumulação normal de 16,5 milhões de metros cúbicos de água e por um sistema de irrigação por aspersão que atinge 1.100 hectares de área irrigável.

Ainda de acordo com a COHIDRO (2012), área do perímetro está localizada dentro da bacia do rio Traíras, afluente pela margem esquerda do rio Vaza Barris, e seus tributários. A área de drenagem existente até a seção do rio Traíras onde há a barragem é de 195 quilômetros quadrados.

As principais culturas exploradas no PIPR segundo a COHIDRO (2012) são: batata-doce, coentro, cebolinha, pimentão, tomate, couve, amendoim, berinjela, alface e feijão.

Figura 1 - Localização do município de Itabaiana - SE.

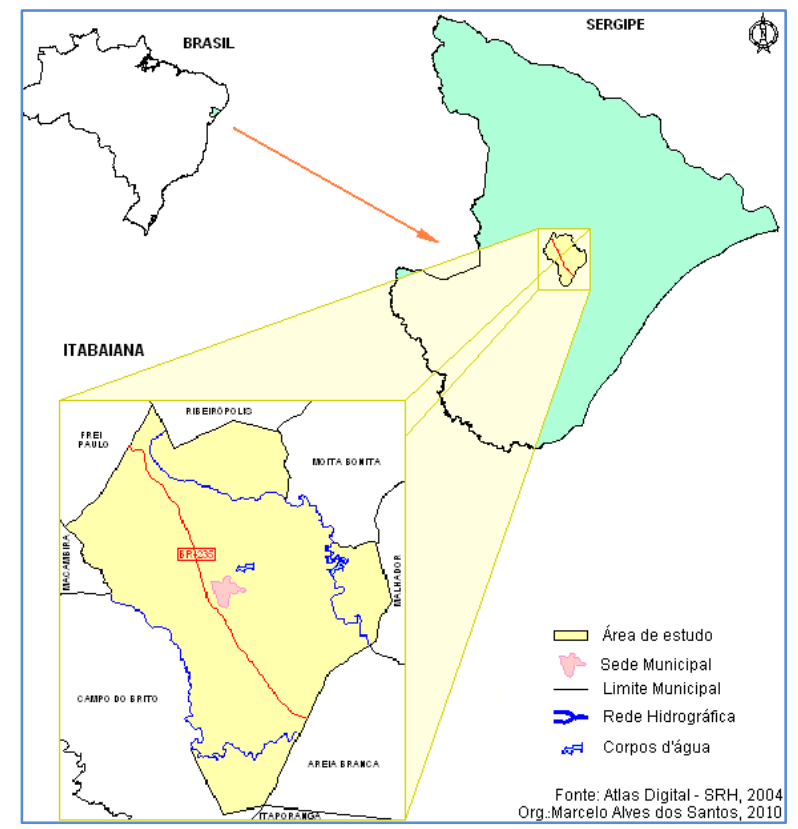

Fonte: Organizado por Marcelo Alves Santos (2010). 
Figura 2 - Localização dos perímetros irrigados Poção da Ribeira e Jacarecica I em Itabaiana-SE.

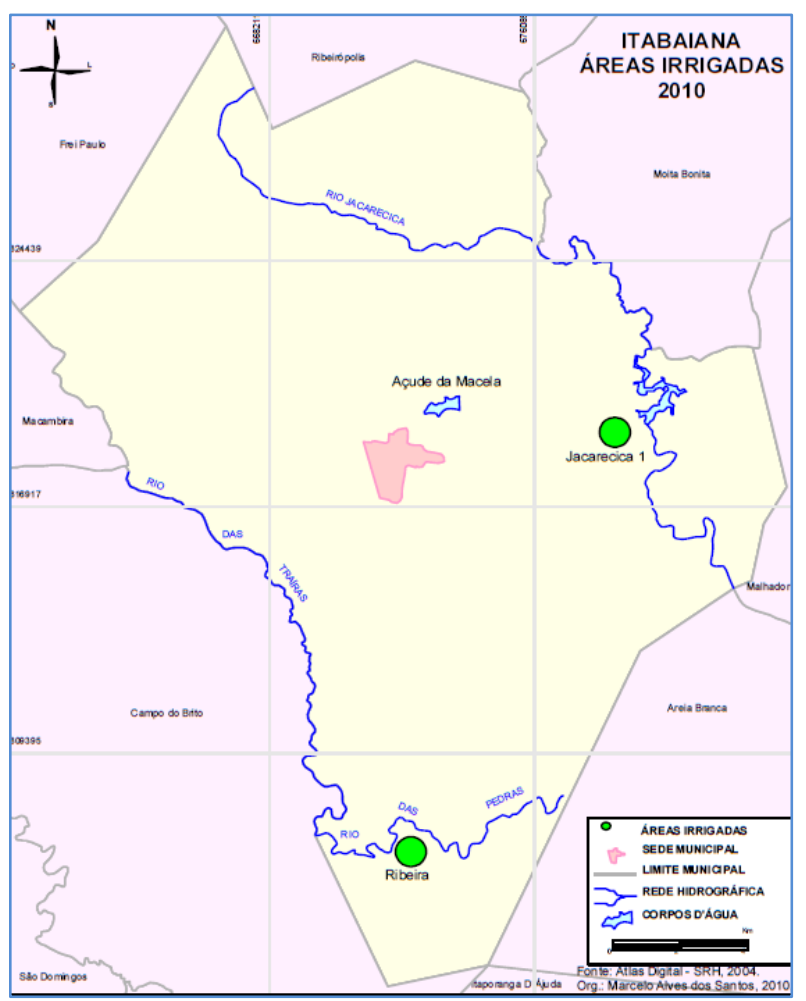

Fonte: Organizado por Marcelo Alves dos Santos, 2010.

\subsection{DADOS CLIMÁTICOS.}

Os valores de pluviosidade (em milímetros), umidade relativa do ar (em porcentagem), velocidade do vento (em metros por segundo), insolação diária (por horas) e temperaturas máximas e mínimas (ambas em graus Celsius), foram fornecidos pela COHIDRO e são valores médios mensais relacionados ao período entre 2004 e 2013 obtidos na estação meteorológica do PIPR (Figura 2), que está localizada na latitude $10^{\circ} 56^{\prime} \mathrm{S}$, longitude $37^{\circ} 39^{\prime} \mathrm{W}$, a 160 metros acima do nível do mar.

Figura 3. Estação meteorológica no PIPR em Itabaiana-SE.

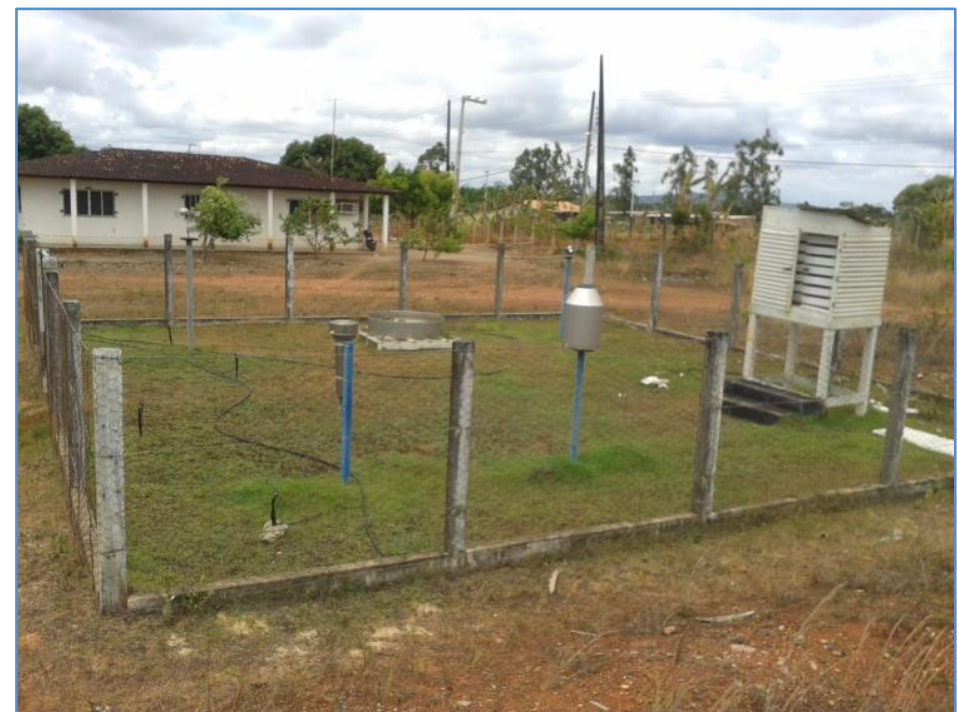

Fonte: Augusto César Barros Rocha/COHIDRO (2015). 
A avaliação dos dados meteorológicos do PIPR foi feita a partir dos dados meteorológicos do Perímetro Irrigado Jacarecica I (PIJAC I), localizado no município de Itabaiana e administrada pela COHIDRO. A estação meteorológica do PIJAC I está localizada na latitude $10^{\circ} 44^{\prime} \mathrm{S}$, longitude $37^{\circ} 20^{\prime} \mathrm{W}$ e a 161 metros acima do nível do mar.

Para calcular os componentes azul e verde da Pegada Hídrica de 2010, 2011 e 2012, foram utilizados os dados específicos dos respectivos anos disponibilizados pela estação meteorológica do PIPR.

A partir dos dados meteorológicos obtidos da COHIDRO e juntamente com o software CROPWAT 8.0 da FAO, foi determinado os valores da evapotranspiração de referência (ETo) (Equação 1), precipitação efetiva (Peff) e evapotranspiração da cultura (ETc) (Equação 2).

\subsection{EVAPOTRANSPIRAÇÃO DE REFERÊNCIA.}

O cálculo da evapotranspiração de referência (ETc) pelo método Penman-Monteith é definido pela seguinte função:

$$
\text { ETo }=\frac{0,408 \Delta(R n-G)+\left(\frac{900 U_{2}}{T+237}\right)\left(e_{a}-e_{s}\right)}{\Delta+y\left(1+0,34 U_{2}\right)}
$$

Em que Rn é o saldo de radiação (MJ m-2 d-1), G refere-se ao fluxo de calor no solo (MJ m-2 d-1), T a temperatura média diária do ar $\left({ }^{\circ} \mathrm{C}\right), \mathrm{U} 2 \mathrm{~m}$ representa a velocidade do vento a $2 \mathrm{~m}$ acima da superfície (ms-1), es - ea é o déficit de pressão de saturação do ar ( $\mathrm{kPa})$, y é a constante psicométrica igual a 0,063 $\mathrm{kPa}{ }^{\circ} \mathrm{C}-1$ e s a simboliza a curva de pressão de saturação de vapor no $\operatorname{ar}\left(\mathrm{KPa}{ }^{\circ} \mathrm{C}\right)$.

\subsection{EVAPOTRANSPIRAÇÃO DA CULTURA (ETC).}

O cálculo da evapotranspiração da cultura (ETc) foi realizado pela multiplicação entre evapotranspiração de referência (ETo) e o coeficiente de cultura (Kc), conforme a seguinte função:

$$
\mathrm{ETc}=\text { Kc } \mathrm{x} \text { ETo }[\mathrm{mm} \text { dia-1] }
$$

\subsection{DADOS SOBRE A CULTURA DA BATATA-DOCE.}

Os dados utilizados sobre a cultura da batata-doce referentes ao período de crescimento e coeficiente de cultivo (Kc) estão de acordo com Allen et al. (1998). Os dados sobre produtividade da cultura da batatadoce no perímetro irrigado Poção da Ribeira provêm da COHIDRO e referem-se às médias anuais de 2010, 2011 e 2012. Segundo a COHIDRO, o período de cultivo da batata-doce é de 120 dias, o que permite a existência de três safras anuais. 
Figura 4. Colheita de batata-doce no PIPR em Itabaiana-SE.

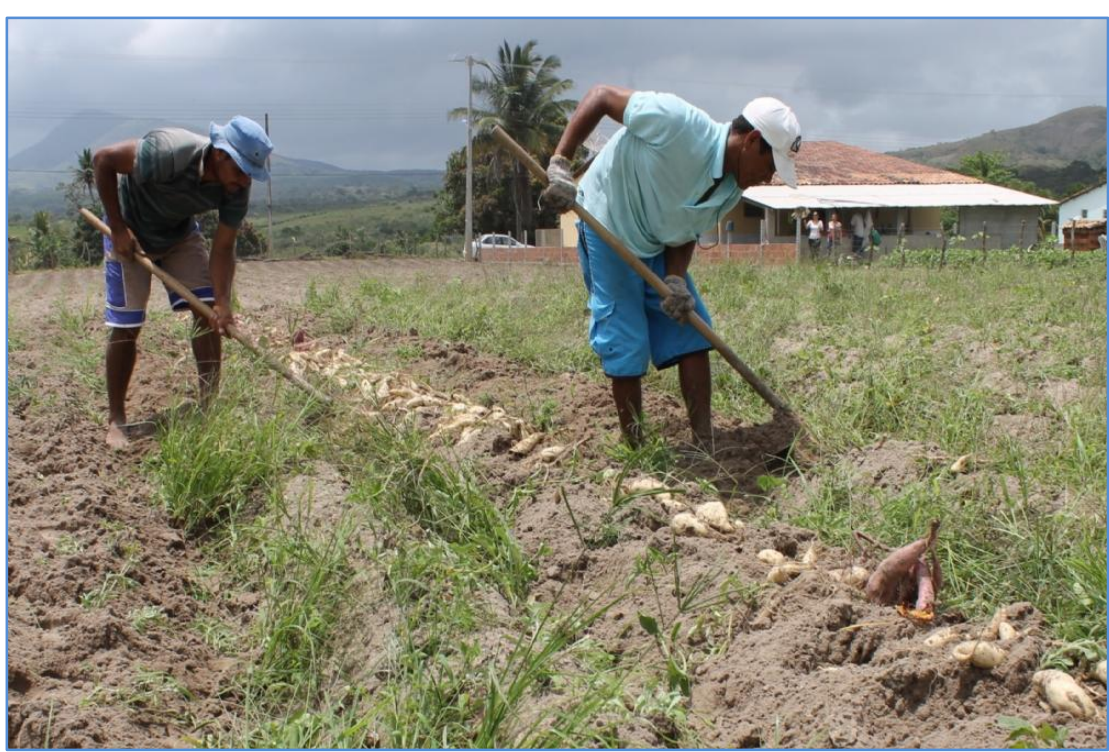

Fonte: Felipe Coringa/Ascom COHIDRO (2012).

\subsection{EVAPOTRANSPIRAÇÃO AZUL E VERDE.}

Os cálculos de evapotranspiração azul e verde basearam-se nas funções apresentadas por Hoekstra et al. (2011) e feitos através do CROPWAT 8.0. A utilizada e citada por Hoekstra et al. (2011) é a opção DHC (demanda hídrica da cultura), onde não são consideradas as limitações hídricas para o crescimento das culturas.

A função da evapotranspiração azul (Equação 3) foi calculada através do valor de evapotranspiração total da cultura (ETc), subtraindo pelo da precipitação efetiva (Peff). Se ETc for maior que Peff, haverá valor positivo de ETazul, porém se Peff for superior a ETc, aplica-se o fator zero, que faz o valor de ETazul ser igual a zero:

$$
\text { ETazul }=\min (0, \text { ETc }- \text { Peff }) \quad[\mathrm{mm} / \text { período }]
$$

A função da evapotranspiração verde (Equação 4) é calculada pelo mínimo entre a evapotranspiração total da cultura (ETc) e a precipitação efetiva (Peff), ou seja, o valor menor entre ambos:

$$
\text { ETverde }=\min (\text { ETc, Peff }) \quad[\mathrm{mm} / \text { período }]
$$

\subsection{DEMANDA HÍDRICA DOS COMPONENTES AZUL E VERDE.}

As demandas hídricas da cultura azul e verde foram calculadas pelas seguintes equações apresentadas por Hoekstra et al. (2011):

$$
\text { DHCazul }=10 X \sum_{d=1}^{p d c} E T a z u l
$$




$$
\text { DHCverde }=10 X \sum_{d=1}^{p d c} \text { ETverde }
$$

ETazul e ETverde são respectivamente as evapotranspirações azul e verde, pdc refere-se ao período de desenvolvimento da cultura em dia, $\mathrm{d}=1$ representa o somatório feito ao longo do período entre o dia do plantio e o dia da colheita e o fator 10 visa a conversão da profundidade da água de milímetros para metros cúbicos por hectare.

\subsection{COMPONENTES DA PEGADA HÍDRICA}

Para determinar os valores dos componentes azul e verde da Pegada Hídrica da cultura da batata-doce, foram utilizadas as seguintes equações aplicadas por Hoekstra et al. (2011):

$$
\begin{gathered}
\text { PHazul }=\frac{\text { DHCazul }}{\text { Prtv }} \\
\text { PHverde }=\frac{\text { DHCverde }}{\text { Prtv }}
\end{gathered}
$$

DHCazul e DHCverde representam respectivamente as necessidades hídricas azul (Equação 5) e verde (Equação 6) e Prtv é a produtividade da cultura em toneladas.

\section{RESULTADOS E DISCUSSÃO}

As médias meteorológicas mensais no período entre 2004 e 2013 referentes ao perímetro irrigado Poção da Ribeira necessárias para a obtenção dos valores determinados da evapotranspiração azul e verde através do software CROPWAT 8.0, estão apresentados na Tabela 1:

Tabela 1: Médias meteorológicas mensais entre 2004 e 2013 do PIPR em Itabaiana-SE.

\begin{tabular}{ccccccc} 
Mês & $\begin{array}{l}\text { Temp. } \\
\text { Mín } \\
\left({ }^{\circ} \mathrm{C}\right)\end{array}$ & $\begin{array}{l}\text { Temp. } \\
\text { Max } \\
\left({ }^{\circ} \mathrm{C}\right)\end{array}$ & $\begin{array}{l}\text { Umid } \\
(\%)\end{array}$ & $\begin{array}{l}\text { Vel. } \\
\text { Vento } \\
(\mathrm{m} / \mathrm{s})\end{array}$ & $\begin{array}{l}\text { Insolação } \\
\text { (horas })\end{array}$ & $\begin{array}{c}\text { Prec. } \\
(\mathrm{mm})\end{array}$ \\
\hline Janeiro & 22,3 & 33 & 49 & 2,4 & 7,3 & 47,7 \\
\hline Fevereiro & 22,8 & 32,2 & 47 & 2,3 & 7,6 & 77,5 \\
\hline Março & 23,5 & 33 & 51 & 2,1 & 8,6 & 93,2 \\
\hline Abril & 23,3 & 31,7 & 53 & 1,7 & 6,7 & 145,4 \\
\hline Maio & 22,3 & 28,9 & 58 & 1,5 & 5,6 & 213,1 \\
\hline Junho & 21,5 & 27,6 & 54 & 1,6 & 4,9 & 187,6 \\
\hline Julho & 20,8 & 27,2 & 54 & 1,7 & 4,6 & 177,4 \\
\hline Agosto & 20,4 & 28,1 & 52 & 1,8 & 5,9 & 137,2 \\
\hline Setembro & 21 & 28,1 & 43 & 2,1 & 6,9 & 94,8 \\
\hline Outubro & 21,8 & 29,1 & 43 & 2,4 & 6,8 & 54,6 \\
\hline Novembro & 22,3 & 30,5 & 47 & 2,7 & 8,9 & 23,5 \\
\hline Dezembro & 22,4 & 31,2 & 46 & 2,6 & 8,5 & 21,1 \\
\hline
\end{tabular}

Fonte: COHIDRO (2014). 
Com as médias meteorológicas disponíveis, permitiu-se os cálculos, através do CROPWAT 8.0 dos valores anuais de evapotranspiração de referência (ETo), evapotranspiração da cultura (ETc) da batata-doce e de precipitação efetiva (Peff) do perímetro irrigado Poção da Ribeira correspondendo à soma dos períodos de três ciclos anuais da cultura, onde cada ciclo dura até 120 dias segundo Melo et al. (2009).

Antes de avançar nos cálculos para encontrar os valores dos componentes azul e verde da Pegada Hídrica da batata-doce, primeiramente se avaliou as médias meteorológicas do PIPR obtidas, através da apresentação do mesmo tipo de informações de um local próximo ao perímetro, mais precisamente o Perímetro Irrigado Jacarecica I (PIJAC I), localizado no município de Itabaiana, e administrado pela COHIDRO e cujas médias meteorológicas também são correspondentes ao período entre 2004 e 2013 :

Tabela 2: Médias meteorológicas mensais entre 2004 e 2013 do PIJAC I em Itabaiana-SE.

\begin{tabular}{ccccccc} 
Mês & $\begin{array}{l}\text { Temp. } \\
\text { Mín } \\
\left({ }^{\circ} \mathrm{C}\right)\end{array}$ & $\begin{array}{l}\text { Temp. } \\
\text { Max } \\
\left({ }^{\circ} \mathrm{C}\right)\end{array}$ & $\begin{array}{l}\text { Umid } \\
(\%)\end{array}$ & $\begin{array}{l}\text { Vel. } \\
\text { Vento } \\
(\mathrm{m} / \mathrm{s})\end{array}$ & $\begin{array}{l}\text { Insolação } \\
\text { (horas })\end{array}$ & $\begin{array}{c}\text { Prec. } \\
(\mathrm{mm})\end{array}$ \\
\hline Janeiro & 21,5 & 31,7 & 53 & 1,5 & 8,5 & 55,7 \\
\hline Fevereiro & 21,4 & 31,2 & 57 & 1,4 & 7,4 & 54 \\
\hline Março & 22,1 & 32 & 59 & 1,3 & 7,8 & 59 \\
\hline Abril & 21,2 & 29,7 & 62 & 1,1 & 6,7 & 147,5 \\
\hline Maio & 21,8 & 28,2 & 62 & 0,9 & 5,5 & 211,9 \\
\hline Junho & 21,9 & 28,5 & 67 & 0,9 & 5 & 172,2 \\
\hline Julho & 21,1 & 28,1 & 69 & 0,9 & 4,3 & 172,2 \\
\hline Agosto & 21 & 28,5 & 58 & 1,1 & 5,8 & 128,2 \\
\hline Setembro & 21,5 & 29,2 & 60 & 1,2 & 6,8 & 85 \\
\hline Outubro & 21,8 & 30,1 & 53 & 1,3 & 6,8 & 74,3 \\
\hline Novembro & 22,7 & 31,7 & 50 & 1,6 & 8,4 & 20,6 \\
\hline Dezembro & 22,9 & 33,3 & 53 & 1,6 & 8,6 & 25,6 \\
\hline
\end{tabular}

Fonte: COHIDRO (2014).

O passo seguinte na avaliação das médias meteorológicas do PIPR foi comparar as suas médias anuais com as do PIJAC I, ambas apresentadas na Tabela 3:

Tabela 3: Médias meteorológicas anuais entre 2004 e 2013 do PIPR e do PIJAC I em Itabaiana-SE

\begin{tabular}{ccccccc} 
Mês & $\begin{array}{c}\text { Temp. } \\
\text { Mín } \\
\left({ }^{\circ} \mathrm{C}\right)\end{array}$ & $\begin{array}{c}\text { Temp. } \\
\text { Max } \\
\left({ }^{\circ} \mathrm{C}\right)\end{array}$ & $\begin{array}{c}\text { Umid } \\
(\%)\end{array}$ & $\begin{array}{c}\text { Vel. } \\
\text { Vento } \\
(\mathrm{m} / \mathrm{s})\end{array}$ & $\begin{array}{c}\text { Insolação } \\
\text { (horas) }\end{array}$ & $\begin{array}{c}\text { Prec. } \\
(\mathrm{mm})\end{array}$ \\
\hline PIPR & 22 & 30 & 50 & 2,1 & 6,9 & 106,1 \\
\hline PIJAC I & 21,7 & 30,2 & 59 & 1,2 & 6,8 & 101,6 \\
\hline
\end{tabular}

Fonte: COHIDRO (2014).

Com base nas médias apresentadas, verificou-se que a média anual do PIPR em relação ao PIJAC I é aproximadamente 1,4\% maior na temperatura mínima, 0,7\% menor na temperatura máxima, 18\% menor na umidade relativa do ar, 42,9\% maior na velocidade do vento, 1,5\% maior na insolação e 4,2\% maior na precipitação.

Após a comparação entre as médias meteorológicas, pode-se avançar no trabalho dos dados do PIPR para a obtenção dos valores de Pegada Hídrica da cultura da batata-doce. 
A partir dos valores obtidos de evapotranspiração da cultura (ETc) e de precipitação efetiva (Peff) de 2010, 2011 e 2012, foram calculados os respectivos valores da evapotranspiração azul (Etazul) e evapotranspiração verde (Etverde) através das Equações 3 e 4 respectivamente, cujos resultados estão apresentados na Figura 5:

Figura 5: Valores de evapotranspiração azul e verde da cultura da batata-doce em 2010, 2011 e 2012 no PIPR em Itabaiana - SE.

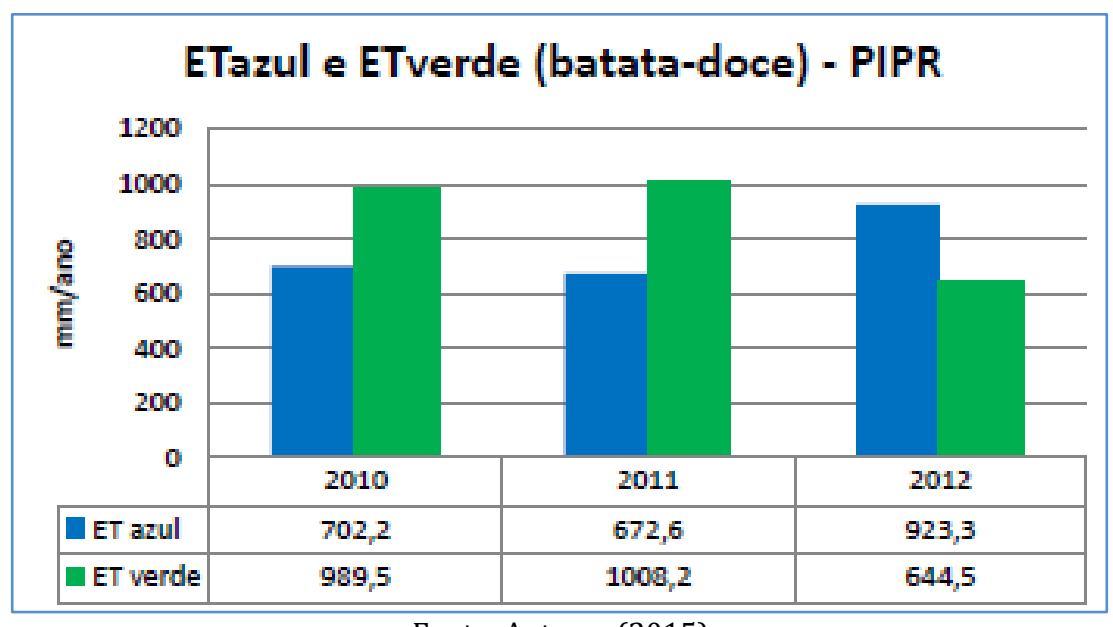

Fonte: Autores (2015).

A partir dos valores obtidos de ETazul e ETverde, observou-se que os valores de 2010 e 2011 mostram que ETverde é superior que ETazul e que há proximidade nos valores de ambos os componentes em ambos os anos, enquanto notou-se uma inversão em 2012, onde ETazul possui valor superior ao da ETverde.

Obtidos os valores de ETazul e ETverde, foram calculados os componentes azuis (DHCazul) e verde (DHCverde) da demanda hídrica da cultura da batata-doce através das Equações 5 e 6 respectivamente, cujos resultados estão apresentados na Figura 6:

Figura 6: Valores de demanda hídrica da cultura azul e verde da cultura da batata-doce em 2010, 2011 e 2012 no PIPR em Itabaiana-SE

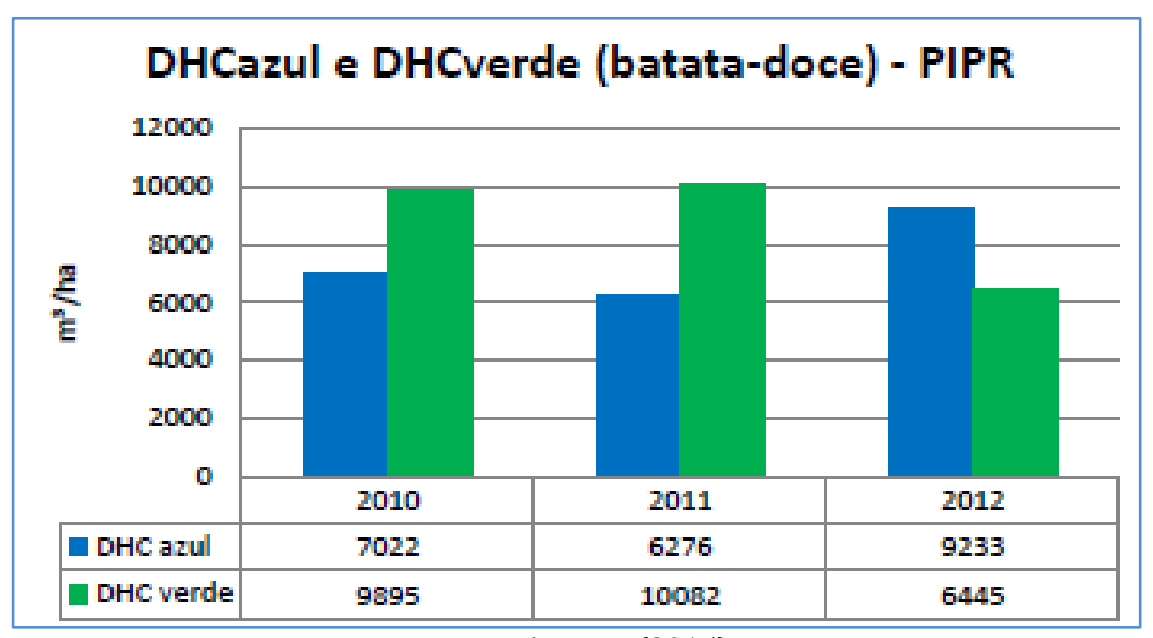

Fonte: Autores (2015).

Observou-se que os resultados de DHCazul e DHCverde de 2010 e 2011 mostram que DHCverde supera DHCazul em ambos os anos e que houve nos valores de 2012 alteração onde DHCverde é inferior a DHCazul. Tendência diferente da apresentada pelo trabalho de Albuquerque (2013) relacionado à Pegada Hídrica da cultura da cana-de-açúcar no estado da Paraíba, onde se observou que em níveis diferentes de 
irrigação, a DHCverde manteve valores próximos quando se aplicou maior quantidade de água azul no cultivo, mas que houve aumento da DHCazul por essa razão.

Para determinar a Pegada Hídrica azul e verde da cultura da batata-doce nos anos de 2010, 2011 e 2012 foram necessários valores de produtividade médios anuais cujos valores estão apresentados na Tabela 4:

Tabela 4: Médias anuais de 2010, 2011 e 2012 de produtividade da cultura da batata-doce no PIPR em Itabaiana-SE.

\begin{tabular}{cccc} 
Ano & 2010 & 2011 & 2012 \\
\hline Produtividade (ton/ha) & 20 & 15 & 16 \\
\hline
\end{tabular}

Fonte: COHIDRO (2014).

Com os DHCazul, DHCverde e as médias anuais de produtividade disponíveis, foram obtidos os valores de 2010, 2011 e 2012 da Pegada Hídrica azul (PHazul) e da Pegada Hídrica verde (PHverde) através das Equações 7 e 8 respectivamente. Os valores estão apresentados na Figura 7:

Figura 7: Valores de Pegada Hídrica azul e verde da cultura da batata-doce em 2010, 2011 e 2012 no PIPR em Itabaiana-SE

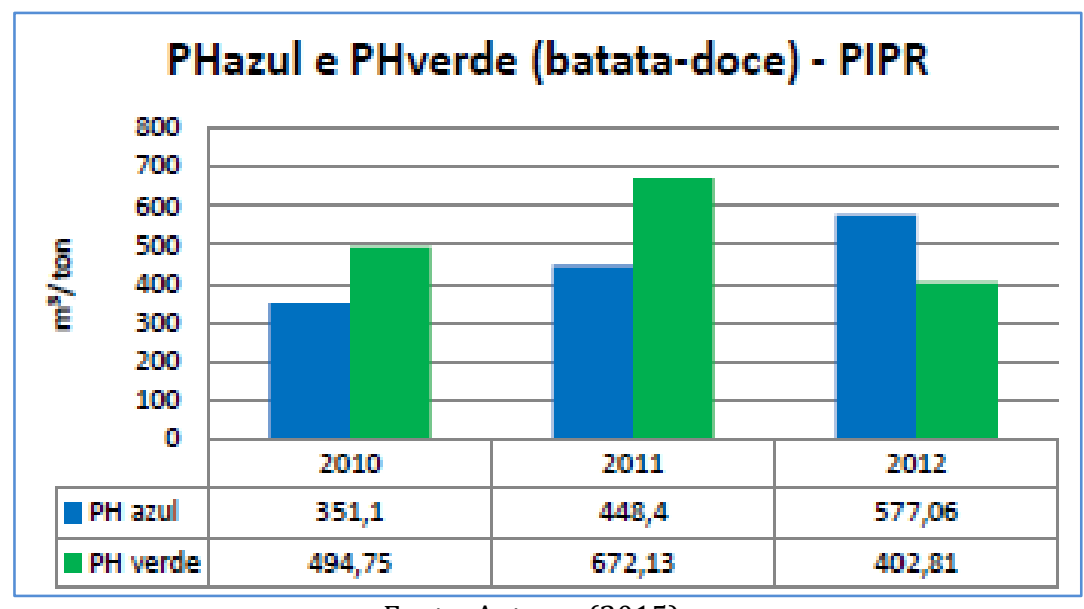

Fonte: Autores (2015).

Em 2010 e 2011, os valores de PHverde são maiores que os de PHazul em ambos os anos, enquanto 2012 apresenta a inversão de relevância entre os componentes azul e verde da $\mathrm{PH}$ observadas na evapotranspiração e na demanda hídrica da cultura, onde o componente azul possui valor mais alto que o verde.

Fenômeno distinto em comparação ao trabalho de Albuquerque (2013) relacionado à PH da cana-deaçúcar no estado da Paraíba, notou-se que praticamente não houve reduções na PHverde quando se aplicou maior quantidade de água azul na cultura, mas que houve aumento da PHazul por essa razão.

Já em relação ao trabalho de Müller (2012), que calculou a PH da produção do biodiesel de soja em todas as suas etapas, observou-se que na fase agrícola do processo, de produção da matéria-prima, houve a utilização do componente verde para o cultivo da soja e de sementes, enquanto o componente azul teve aplicação limitada à produção de insumos, indicando que o cultivo baseou-se o sistema de sequeiro, diferentemente do que ocorre com a cultura da batata-doce no PIPR.

Em relação à soma dos valores de PH dos componentes verde e azul de 2010, 2011 e 2012, fez-se uma comparação com os índices de produtividade média anual do cultivo da batata-doce, demonstrados na Tabela 5: 
Tabela 5: Comparação entre valores combinados de PH e médias de produtividade da batata-doce de 2010, 2011 e 2012 no PIPR em Itabaiana-SE

\begin{tabular}{ccccc}
\hline Ano & PHazul(m3/ton) & PHazul(m3/ton) & PHazul(m3/ton) & $\begin{array}{c}\text { Prod. } \\
\text { (ton/ha) }\end{array}$ \\
\hline 2010 & 351,1 & 494,75 & 845,85 & 20 \\
\hline 2011 & 448,4 & 672,13 & 1120,53 & 15 \\
\hline 2012 & 577,06 & 402,81 & 979,87 & 16 \\
\hline
\end{tabular}

Fonte: Autores (2015).

A produtividade média da batata-doce de 2010 é 25\% superior ao de 2011 e $20 \%$ superior ao de 2012 . A soma dos componentes azul e verde da PH de 2010 é aproximadamente 24,5\% menor que o de 2011 e $13,7 \%$ menor que o de 2012. Isso significa que se pode relacionar um menor índice médio anual de produtividade da batata-doce com maior consumo de água observado através da PH independentemente da relevância que os componentes azul e verde possam ter no valor combinado.

Sobre a existência de diferenças de valores apresentadas nas Figuras 5, 6 e 7, elas podem ser explicadas a partir de diferenças entre as médias meteorológicas mensais de 2010 (Tabela 6), 2011 (Tabela 7) e 2012 (Tabela 8) no PIPR:

Tabela 6: Médias meteorológicas mensais de 2010 do PIPR em Itabaiana-SE

\begin{tabular}{ccccccc} 
Mês & $\begin{array}{c}\text { Temp. } \\
\text { Mín } \\
\left({ }^{\circ} \mathrm{C}\right)\end{array}$ & $\begin{array}{c}\text { Temp. } \\
\text { Max } \\
\left({ }^{\circ} \mathrm{C}\right)\end{array}$ & $\begin{array}{c}\text { Umid } \\
(\%)\end{array}$ & $\begin{array}{c}\text { Vel. } \\
\text { Vento } \\
(\mathrm{m} / \mathrm{s})\end{array}$ & $\begin{array}{c}\text { Insolação } \\
\text { (horas })\end{array}$ & $\begin{array}{c}\text { Prec. } \\
(\mathrm{mm})\end{array}$ \\
\hline Janeiro & 22,2 & 31,9 & 45 & 2,2 & 8,4 & 35 \\
\hline Fevereiro & 22 & 30,9 & 50 & 2,3 & 7,6 & 78,8 \\
\hline Março & 22,5 & 31,7 & 48 & 2,2 & 7,5 & 92,1 \\
\hline Abril & 20,9 & 28,5 & 46 & 1,6 & 3,9 & 247 \\
\hline Maio & 18,9 & 28,5 & 55 & 1,3 & 6,4 & 147,6 \\
\hline Junho & 19,1 & 24,9 & 46 & 1,7 & 3,2 & 355,2 \\
\hline Julho & 18 & 24,4 & 43 & 1,9 & 5,4 & 184,1 \\
\hline Agosto & 18,5 & 34 & 39 & 1,8 & 5,8 & 119,6 \\
\hline Setembro & 21,4 & 28,5 & 36 & 2,3 & 4,6 & 175,2 \\
\hline Outubro & 20,3 & 30,3 & 34 & 2,5 & 3,5 & 37,6 \\
\hline Novembro & 21,2 & 32 & 70 & 2,9 & 10 & 0 \\
\hline Dezembro & 23,1 & 33 & 47 & 2,6 & 8,2 & 8,2 \\
\hline
\end{tabular}


Editora Poisson - Volume xx

Tabela 7: Médias meteorológicas mensais de 2011 do PIPR em Itabaiana-SE

\begin{tabular}{ccccccc} 
Mês & $\begin{array}{c}\text { Temp. } \\
\text { Mín } \\
\left({ }^{\circ} \mathrm{C}\right)\end{array}$ & $\begin{array}{c}\text { Temp. } \\
\text { Max } \\
\left({ }^{\circ} \mathrm{C}\right)\end{array}$ & $\begin{array}{c}\text { Umid } \\
(\%)\end{array}$ & $\begin{array}{c}\text { Vel. } \\
\text { Vento } \\
(\mathrm{m} / \mathrm{s})\end{array}$ & $\begin{array}{c}\text { Insolação } \\
\text { (horas })\end{array}$ & $\begin{array}{c}\text { Prec. } \\
(\mathrm{mm})\end{array}$ \\
\hline Janeiro & 21 & 30,2 & 51 & 2,3 & 5,6 & 67,4 \\
\hline Fevereiro & 20,2 & 27,8 & 41 & 6,3 & 7,1 & 56 \\
\hline Março & 21,9 & 33,2 & 47 & 2 & 8,7 & 116 \\
\hline Abril & 21,8 & 29,4 & 51 & 1,5 & 6,8 & 245,6 \\
\hline Maio & 20,8 & 26 & 58 & 1,5 & 4,1 & 220,4 \\
\hline Junho & 17,66 & 24,2 & 52 & 1,1 & 6 & 138,7 \\
\hline Julho & 18,7 & 26,1 & 52 & 1,6 & 4,6 & 142,8 \\
\hline Agosto & 18,1 & 25,8 & 46 & 1,6 & 7,3 & 94,1 \\
\hline Setembro & 18,3 & 26,4 & 46 & 1,9 & 5,9 & 74,9 \\
\hline Outubro & 20,4 & 29,4 & 47 & 2,5 & 7,5 & 72 \\
\hline Novembro & 23 & 31,4 & 53 & 2,3 & 6,6 & 107 \\
\hline Dezembro & 23,2 & 32,5 & 51 & 2,5 & 6,7 & 1,2 \\
\hline & & Fonte: COHIDRO $(2014)$ & &
\end{tabular}

Tabela 8: Médias meteorológicas mensais de 2012 do PIPR em Itabaiana-SE

\begin{tabular}{ccccccc} 
Mês & $\begin{array}{c}\text { Temp. } \\
\text { Mín } \\
\left({ }^{\circ} \mathrm{C}\right)\end{array}$ & $\begin{array}{c}\text { Temp. } \\
\text { Max } \\
\left({ }^{\circ} \mathrm{C}\right)\end{array}$ & $\begin{array}{c}\text { Umid } \\
(\%)\end{array}$ & $\begin{array}{c}\text { Vel. } \\
\text { Vento } \\
(\mathrm{m} / \mathrm{s})\end{array}$ & $\begin{array}{c}\text { Insolação } \\
\text { (horas })\end{array}$ & $\begin{array}{c}\text { Prec. } \\
(\mathrm{mm})\end{array}$ \\
\hline Janeiro & 23,5 & 32,5 & 55 & 2,5 & 6,7 & 24,8 \\
\hline Fevereiro & 23,6 & 32,7 & 56 & 2 & 6,9 & 93,9 \\
\hline Março & 23 & 32,6 & 56 & 2,4 & 8,9 & 20 \\
\hline Abril & 23 & 33 & 58 & 2,1 & 8,3 & 12,6 \\
\hline Maio & 23,1 & 31,3 & 63 & 2 & 6,6 & 127,5 \\
\hline Junho & 21,6 & 29,2 & 67 & 1,8 & 6,3 & 92,5 \\
\hline Julho & 19,1 & 26 & 80 & 1,9 & 5,2 & 131,2 \\
\hline Agosto & 20,2 & 27,6 & 92 & 2,1 & 6,5 & 157,8 \\
\hline Setembro & 20,2 & 28,2 & 76 & 2,4 & 6,8 & 102,3 \\
\hline Outubro & 19,9 & 27,1 & 76 & 2,3 & 7,1 & 23,9 \\
\hline Novembro & 20,8 & 30,9 & 56 & 2,8 & 8,6 & 0 \\
\hline Dezembro & 21,2 & 31,1 & 65 & 2,8 & 9,3 & 10 \\
\hline
\end{tabular}

Fonte: COHIDRO (2014).

A partir destes dados, foi feita uma comparação entre as médias anuais aproximadas de 2010, 2011 e 2012 de cada um dos dados meteorológicos com as respectivas médias anuais de produtividade da cultura da batata-doce no PIPR. A comparação está apresentada na Tabela 9: 
Tabela 9: Comparação entre médias meteorológicas anuais e médias de produtividade da batata-doce de 2010, 2011 e 2012 no PIPR em Itabaiana-SE

\begin{tabular}{cccccccc} 
Ano & $\begin{array}{c}\text { Temp. } \\
\text { Mín } \\
\left({ }^{\circ} \mathrm{C}\right)\end{array}$ & $\begin{array}{c}\text { Temp. } \\
\text { Max } \\
\left({ }^{\circ} \mathrm{C}\right)\end{array}$ & $\begin{array}{c}\text { Umid } \\
(\%)\end{array}$ & $\begin{array}{c}\text { Vel. } \\
\text { Vento } \\
(\mathrm{m} / \mathrm{s})\end{array}$ & $\begin{array}{c}\text { Insolação } \\
\text { (horas) }\end{array}$ & $\begin{array}{c}\text { Prec. } \\
(\mathrm{mm})\end{array}$ & $\begin{array}{c}\text { Prod. } \\
\text { (ton/ha) }\end{array}$ \\
\hline 2010 & 20,7 & 29,7 & 47 & 2,1 & 6,2 & 123,4 & 20 \\
\hline Fevereiro & 20,4 & 28,5 & 50 & 2,3 & 6,4 & 111,3 & 15 \\
\hline Março & 21,6 & 30,2 & 67 & 2,3 & 7,3 & 66,7 & 16 \\
\hline
\end{tabular}

Fonte: COHIDRO (2014).

Com base nestes dados, observou-se que a média de precipitação em 2012 tem valor aproximadamente 45,1\% inferior à de 2010 e 40,1\% inferior à de 2011, causando a necessidade de cobrir a deficiência de água verde na cultura da batata-doce com água azul em 2012, refletindo no maior peso da PHazul sobre a PHverde nesse ano, algo inverso ao que foi notado em 2010 e 2011, onde a maior quantidade de precipitação fez a demanda por água proveniente de irrigação ser menor.

Diante disso, as diferenças apresentadas nas Figuras 5, 6 e 7 permitem considerar que a oferta de água através da precipitação contribuiu na relação entre os componentes azul e verde da PH. Quanto maior a precipitação, maior será o aproveitamento da água proveniente dela por parte da cultura da batata-doce e menor será a necessidade de se completar a quantidade de água para o desenvolvimento do cultivo e viceversa.

Também foi notado que as variações apresentadas entre as médias de produtividade da batata-doce não podem ser explicadas pelas variáveis meteorológicas utilizadas nos cálculos da Pegada Hídrica, pois a variação das médias de 2010, 2011 e 2012 em cada uma delas não segue a mesma proporção de variação dos índices médios de produtividade da batata-doce correspondentes a período avaliado.

A partir das relações observadas entre a variação na produtividade da batata-doce com o consumo de água, sendo que menor produtividade representa maior consumo de água, ou seja, maior PH, e da influência exercida pela precipitação, por influir diretamente na oferta de água azul e verde utilizada na cultura, pode-se estabelecer parâmetros para otimizar a produtividade da batata-doce.

Como há mais de um ciclo anual de cultivo da batata-doce na Poção da Ribeira, possibilitando grande rotatividade, então é possível, por exemplo, optar por aumentar ou diminuir a área de plantio para o ciclo seguinte caso o anterior tenha rendimento maior ou menor na produtividade, ou mesmo alterando os períodos de plantio para reduzir o consumo de água azul, porém no caso específico do PIPR, faltam informações precisas específicas de cada ciclo, considerando que os produtores de cada lote do perímetro irrigado seguem seus próprios planos de produção agrícola seguindo suas respectivas necessidades econômicas.

Mesmo com essas limitações, os valores estimados dos componentes azul e verde da Pegada Hídrica podem ser adicionados aos estudos sobre a cultura da batata-doce em combinação com outros trabalhos relacionados, como o de Melo et al. (2009), que trata dos custos de produtividade da batata-doce, auxiliando em cálculos sobre os custos financeiros da produção na parte sobre o consumo de água e oferecendo um novo índice para facilitar a definição com maior exatidão as necessidades hídricas para desenvolver as safras da batata-doce no PIPR de modo a conciliar suas demandas hídricas com a de outras culturas existentes no perímetro.

\section{CONCLUSÕES}

A partir dos dados estimados e apresentados sobre a Pegada Hídrica da produção de batata-doce no perímetro irrigado Poção da Ribeira, concluindo que se pode relacionar um índice anual de produtividade da batata-doce com um maior consumo de água no qual reflete consequentemente em uma Pegada Hídrica maior, independentemente da relação entre os componentes azul e verde nos valores combinados.

A Pegada Hídrica da batata-doce sofreu influência da precipitação, o que resultou em maior relevância ao componente verde quando a média pluviométrica anual foi maior (2010 e 2011) e maior relevância ao componente azul quando a média de precipitação foi menor, no caso, 2012 em relação a 2010 e 2011 . Não 
foi notada relação direta entre as variações dos índices de produtividade da cultura da batata-doce com as variáveis meteorológicas utilizadas nos cálculos da $\mathrm{PH}$.

\section{REFERÊNCIAS}

[1] AlbuQUerque, M. F. Medições e Modelagem da Pegada Hídrica da Cana-de-Açúcar Cultivada no Brasil. 2013. 40 f. Dissertação (Mestrado em Meteorologia). Universidade Federal de Campina Grande, Campina Grande, PB, 2013.

[2] ALLEN, R. G.; PEREIRA, L. S., RAES, D.; SMITH, M. Crop Evapotranspiration: Guidelines for Computing Crop Water Requirements.FAO Irrigation and Drainage Paper 56. Rome, 1998.

[3] COMPANHIA DE RECURSOS HÍDRICOS DO ESTADO DE SERGIPE. Relatório de Atividades Exercício 2012. Aracaju: Cohidro, 2012.63p.

[4] GERBEnS-LEENES, W.; HOEKSTRA, A. Y.; VAN DER MEER, T. The Water Footprint of Bioenergy. Proceeding of National Academy of Sciences, v. 106, n. 25, p. 10219-10223, 2009.

[5] Hoekstra, A. Y.; Chapagain, A. K.; ALDAYA, M.; MEKOnNEN, M. M. Manual de Avaliação da Pegada Hídrica: Estabelecendo o Padrão Global. Water Footprint Network, 2011. 191p.

[6] MELO, A. S.; COSTA, B. C.; BRITO, M. E. B.; NETTO, A. O. A.; VIÉGAS, P. R. A. Custo e Rentabilidade na Produção de Batata-Doce nos Perímetros Irrigados de Itabaiana, Sergipe. Pesquisa Agropecuária Tropical, v. 39, n. 2, p. 119123, 2009.

[7] MÜLlER, G. T. Emprego da Pegada Hídrica e da Análise de Ciclo de Vida para a Avaliação do Uso da Água na Cadeia Produtiva do Biodiesel de Soja. 2012. 188 f. Dissertação (Mestrado em Recursos Hídricos e Saneamento Ambiental). Universidade Federal do Rio Grande do Sul, Porto Alegre, RS, 2012. 


\title{
Capítulo 2
}

\section{Análise microbiológica de cenoura e beterraba irrigadas com águas residuárias domésticas tratadas}

\author{
Iasmine Louise de Almeida Dantas \\ Gregorio Guirado Faccioli \\ Alane Regina Rodrigues dos Santos \\ Luiz Ricardo Santana de Araújo
}

Resumo: A utilização de águas residuárias domésticas tratadas para irrigação pode se tornar uma alternativa para regiões que enfrentam escassez de água, como na região Nordeste do Brasil, especificamente no Estado de Sergipe. O presente trabalho teve como objetivo analisar a influência do uso de águas residuárias domésticas tratadas na qualidade microbiológica de cenouras (Daucus carota) e beterrabas (Beta vulgaris) irrigadas com essa água. O experimento foi realizado em casa de vegetação do Departamento de Engenharia Agronômica (DEA), localizada na Universidade Federal de Sergipe/Campus de São Cristóvão no período de abril a julho de 2014. As águas residuárias foram coletadas na Estação de Tratamento de Esgotos (ETE) Rosa Elze, localizada no Município de São Cristóvão/SE. As irrigações foram feitas utilizando-se quatro diluições diferentes. A evapotranspiração foi obtida pelo método do Food and Agriculture Organization of United Nations (FAO) 56 através de estação meteorológica montada dentro da casa de vegetação. 0 delineamento experimental utilizado foi o de blocos casualizados (DBC), composto por oito tratamentos, sendo duas espécies e quatro percentuais de água residuária e/ou água potável da Companhia de Abastecimento de Sergipe (DESO); 100\% água da DESO; 75\% água da DESO + 25\% água residuária; 75\% água residuária + 25\% água da DESO e 100\% água residuária, em cinco repetições e quatro plantas por parcela útil. Os resultados obtidos nas análises de qualidade microbiológicas demonstram que a beterraba e a cenoura irrigadas com água residuária encontram-se de acordo com os padrões estabelecidos pela legislação vigente (Salmonella sp. ausência em 25 g e coliformes termotolerantes $\leq 3$ NMP. g-1 ) e a enumeração de mesófilos e bolores e leveduras não ultrapassaram 4,5×106, contudo se faz necessário estudos mais aprofundados à temática.

Palavras-chave: água residuária, evapotranspiração, reuso, salmonella e coliformes. 


\section{INTRODUÇÃO}

A agricultura irrigada representa o maior consumidor de água dentre os diversos usuários finais deste recurso natural, chegando a totalizar $80 \%$ do consumo em muitos países. Observa-se a necessidade do desenvolvimento de técnicas de controle da água utilizada na irrigação e como a tecnologia pode estar inserida nas questões que possam oferecer melhoria à produção. 0 manejo adequado da água na agricultura não pode ser considerado uma etapa independente dentro do processo de produção agrícola, visto que este é um sistema integrado. Deve-se considerar o compromisso com a produtividade da cultura explorada, e o uso eficiente da água, que contribui para conservação do meio ambiente.

Uma alternativa encontrada para um consumo de água racionado é o reuso de água ou, ainda em outra forma de expressão, o uso de águas residuárias. Não é um conceito novo e tem sido praticado no mundo todo há diversos anos. Essa reutilização da água pode ocorrer de maneira direta ou indireta, de forma planejada ou não. 0 reuso direto é o uso planejado e deliberado de esgotos tratados, para certas finalidades, como irrigação, uso industrial, recarga de aquífero e água potável. No reuso indireto, a água utilizada uma ou mais vezes, para uso doméstico ou industrial, é lançada nas águas superficiais ou subterrâneas e utilizada novamente à jusante, no sentido da sua foz, já diluída.

0 reuso agrícola se apresenta como uma forma economicamente rentável e benéfica para o meio ambiente, desde que, se observem as medidas necessárias para a preservação da qualidade ambiental, visto que, a qualidade da água para consumo humano e para produção de alimentos é um dos fatores determinantes na saúde coletiva.

A beterraba e a cenoura foram escolhidas para a realização dessa pesquisa por serem hortaliças exigentes em água e ambas serem consumidas crua. Dessa maneira, os resultados microbiológicos foram analisados levando em consideração que as hortaliças não passaram por nenhum processo de sanitização.

Assim o presente trabalho teve o objetivo de analisar o efeito do uso de águas residuárias domésticas na qualidade microbiológica de cenouras e beterrabas irrigadas com essa água verificando se as mesmas enquadram-se nos padrões sanitários aceitáveis.

\section{REFERENCIAL TEÓRICO}

\subsection{IRRIGAÇÃO}

No mundo, uma área de cerca de 1,532 bilhões de hectares está em produção agrícola, dos quais cerca de 278 milhões de hectares são irrigados, correspondendo a $18 \%$ da área plantada, a qual é responsável por mais de $44 \%$ do volume total da produção e $54 \%$ do valor econômico total da produção. Por outro lado, no Brasil, estes números são da ordem de 5\%, 16\% e 35\%, respectivamente (FOLEGATTI et al., 2011 e CHRISTOFIDIS, 2006 ). Dados da Agência Nacional de Águas (2013) revelam que o valor estimado da área irrigada no Brasil em 2010, foi de 5,6 milhões de hectares, 20\% superior ao estimado para o ano de 2006.

Por meio da irrigação, pode-se intensificar a produção agrícola, regularizando, ao longo do ano, as disponibilidades e os estoques de alimentos, uma vez que essa prática permite uma produção na contra estação. A atividade de irrigação é a maior consumidora de água entre os diversos usos desse recurso natural. Dentro dela, os consumos específicos variam bastante, dependendo do método de irrigação empregado. A natureza do solo, o tipo de requerimentos das diferentes culturas e os índices de evaporação locais são elementos importantes para definir o consumo de água para irrigação (HESPANHOL, 2002).

A irrigação não pode e não deve competir com o uso da água destinada ao abastecimento doméstico, que sempre será prioridade. Pela Constituição Brasileira, a ordem de prioridade do uso da água é a seguinte: consumo humano, indústria e, por fim, irrigação. Assim, as águas utilizadas em irrigação são cada vez mais escassas e de pior qualidade. Essa realidade demanda uma busca de adaptação das técnicas de irrigação existentes e amplamente difundidas às condições atuais e futuras de escassez de água. Diante desse panorama, é clara a necessidade de se utilizar esse recurso natural com maior racionalidade, seja através de técnicas que permitam um aproveitamento mais eficiente da água em diversas atividades humanas, como a irrigação ou pela busca de fontes alternativas de água (DUARTE, 2006).

\subsection{REUSO}

A falta de recursos hídricos e o aumento dos conflitos pelo uso da água geraram a emergência da conservação e do tratamento e reuso, como componentes formais da gestão de recursos hídricos. Os 
benefícios inerentes à utilização de água recuperada para usos benéficos, ao contrário de disposição ou descarga, incluem preservação de fontes de qualidade elevada, proteção ambiental e benefícios econômicos e sociais (ASANO et al., 2007).

A utilização das águas residuárias tratadas na agricultura é importante não apenas por servir como fonte extra de água, mas também de nutrientes para as culturas (SANDRI et al., 2007). Nesse contexto, as plantas desempenham papel importante, que é o de utilizar os nutrientes disponibilizados pelas águas residuárias, extraindo macro e micronutrientes, além do carbono (matéria orgânica) necessário ao seu crescimento, evitando seu acúmulo e a consequente salinização do solo e a contaminação das águas superficiais e subterrâneas (RIBEIRO et al., 2009).

Segundo Hespanhol (2003), a água uma vez poluída, pode ser recuperada e reusada para fins benéficos diversos desde que seja utilizada para uso menos restritivos. A qualidade da água utilizada e o objeto do reuso são os fatores que definirão quais serão os níveis de tratamentos recomendados, os critérios de segurança a serem adotados, os custos de capital, de operacionalização e de manutenções. As alternativas de reuso se baseiam de acordo com as características, condições e fatores locais, tais como decisões políticas, esquemas institucionais e disponibilidade.

Qualquer que seja a forma de reuso empregada é fundamental observar que os princípios básicos que devem orientar essa prática são: preservação da saúde dos usuários, preservação do meio ambiente, atendimento consistente às exigências de qualidade, relacionadas ao uso pretendido e proteção dos materiais e equipamentos utilizados nos sistemas de reuso (HESPANHOL, 2002).

A regulamentação do reuso da água apresenta-se em pleno curso no Brasil, devido ao reconhecimento das práticas de reuso no país. É destacado que, a Resolução CNRH No54/2005 coloca a atividade de reuso da água como integrante das políticas de gestão de recursos hídricos vigentes no país, contudo não estabelece parâmetros específicos para seu emprego.

\subsection{ASPECTOS MICROBIOLÓGICOS}

Segundo Pelczar Jr. et al. (1997), os micro-organismos estão intimamente associados com a disponibilidade, a abundância e a qualidade do alimento para consumo humano. Os alimentos são facilmente contaminados com micro-organismos no ambiente, durante a manipulação e o processamento. Após ter sido contaminado, o alimento serve como meio para a multiplicação de micro-organismos. Se esses tiverem condições de se multiplicarem, podem mudar as características físicas e químicas do alimento e podem causar sua deterioração. Os micro-organismos no alimento podem também ser responsáveis por intoxicações e infecções.

Os principais agentes biológicos descobertos nas águas contaminadas são as bactérias patogênicas, os vírus e os parasitas. As bactérias patogênicas encontradas na água e/ou alimentos constituem uma das principais fontes de mortalidade em nosso meio. São as responsáveis pelos numerosos casos de enterites, diarreias infantis e doenças epidêmicas (como a febre tifóide), com resultados frequentemente letais. Os vírus mais comumente encontrados nas águas contaminadas por dejetos humanos, entre outros, são os da poliomielite e da hepatite infecciosa. Dentre os parasitas que podem ser ingeridos através da água destaca-se a Entamoeba histolytica, causadora da amebíase e suas complicações, inclusive para o lado hepático. É encontrada sobretudo em países quentes e em locais onde existem más condições sanitárias (D'AGUILA et al, 2000).

As bactérias são os principais micro-organismos constituintes da microbiota em hortaliças. Isso ocorre, pois o valor do $\mathrm{pH}$ encontrado nesse tipo de alimento $(5,0$ - 6,5) favorece a multiplicação destes microorganismos em relação à multiplicação dos bolores e leveduras (KING et al., 1991).

A existência de inúmeros tipos de microrganismos presentes nas águas residuárias, dificulta o isolamento e a identificação dos patogênicos. Por esse fato existem os microrganismos indicadores de contaminação fecal, por serem de fácil detecção e indicarem a presença de material fecal, sendo utilizado para tanto, um subgrupo dos coliformes totais, denominados coliformes termotolerantes, ou seja, fermentam na presença de lactose com produção de gás e ácido à temperatura de incubação igual a 44,5드 $\pm 0,2^{\circ} \mathrm{C}$ em $24 \pm 2 \mathrm{~h}$. (PAGANINI, 1997). 


\subsection{ANÁLISES MICROBIOLÓGICAS}

Segundo Franco e Landgraf (1996), a análise microbiológica é fundamental para se conhecer as condições de higiene do alimento e os riscos que o alimento pode oferecer à saúde do consumidor. Essa análise é indispensável também para se verificar se os padrões e especificações microbiológicos para alimentos, nacionais ou internacionais, estão sendo atendidos adequadamente.

Segundo Silva et al. (2010), a análise microbiológica de alimentos objetiva a detecção ou a enumeração de microrganismos vivos. Os ensaios utilizados podem ser qualitativos, que verificam a presença ou ausência do(s) microrganismo(s) alvo em uma dada quantidade de amostra, sem a quantificação, e os ensaios quantitativos, que determinam a quantidade do(s) microrganismo(s) alvo na amostra, geralmente por unidade de massa ou volume.

0 procedimento a ser empregado é determinado pelo tipo de alimento que está sendo analisado e pelo propósito específico da análise. A escolha pode também depender dos tipos de microrganismos a serem pesquisados em um alimento (PELCZAR Jr. et al., 1997).

\subsection{BETERRABA (BETA VULGARIS) E CENOURA (DAUCUS CAROTA L.)}

A Beterraba (Beta vulgaris) pertence á família Chenopodiaceae, na qual a parte comestível é a raiz tuberosa. Essa hortaliça tem coloração vermelho-arroxeada devido à presença dos pigmentos betalaínas (VITTI, 2003).

É uma das principais hortaliças cultivadas no Brasil, caracterizada por possuir diversos biótipos e utilização. Desde a beterraba açucareira, utilizada para a extração de açúcares; a forrageira na qual as raízes e as folhas são usadas na alimentação animal e a hortícola ou de mesa, considerada mais importante no Brasil, por usar suas raízes e folhas na alimentação humana. As sementes da beterraba são aglomerados de pequenos frutos corticosos, que são chamados de glomérulos. Cada aglomerado contém de três a quatro sementes, sendo que cada semente é originada de um fruto que apresenta óvulo, gerando mais de uma planta por glomérulos; existindo também no meio comercial glomérulos que possuem apenas uma semente (FILGUEIRA, 2012).

A cenoura (Daucus carota L.) é uma das principais olerícolas cultivas no Brasil. Devido a sua sensibilidade ao déficit hídrico, a aplicação de lâminas de irrigação suficientes para suprir a demanda hídrica da cultura, torna-se um dos fatores mais importantes para a obtenção de altas produtividades (ROSA, 2012).

É uma planta herbácea, pertencente da família Apiaceae, com caule pouco perceptível e uma raiz pivotante, tuberosa e sem ramificações. Suas raízes possuem um alto teor de betacaroteno, precursor da vitamina A. Em termo de importância econômica, é a quinta olerícola cultivada no Brasil (FILGUEIRA, 2012).

Segundo Fontes (2005), a produtividade e a qualidade das raízes de cenoura possuem uma grande influência em relação às condições de umidade do solo. Sendo que, para a obtenção de altos rendimentos, é necessário o controle da umidade do solo durante todo o ciclo da cultura para, deste modo, determinarse o momento da irrigação e a quantidade de água a ser aplicada.

\section{MATERIAL E MÉTODOS}

\subsection{CARACTERIZAÇÃO DA ÁREA DE ESTUDO}

0 experimento foi conduzido em casa de vegetação, localizada no Departamento de Engenharia Agronômica (DEA) da Universidade Federal de Sergipe (UFS), no município de São Cristóvão, Sergipe. Sob as coordenadas geográficas de $10^{\circ}{ }^{\circ} 5^{\prime} 46^{\prime \prime}$ latitude e $37^{\circ} 06^{\prime} 13^{\prime \prime} 0$ longitude, a uma altitude de $8 \mathrm{~m}$. (Figura 1) Foram utilizadas duas bancadas metálicas. 
Figura 1: casa de vegetação DEA/UFS

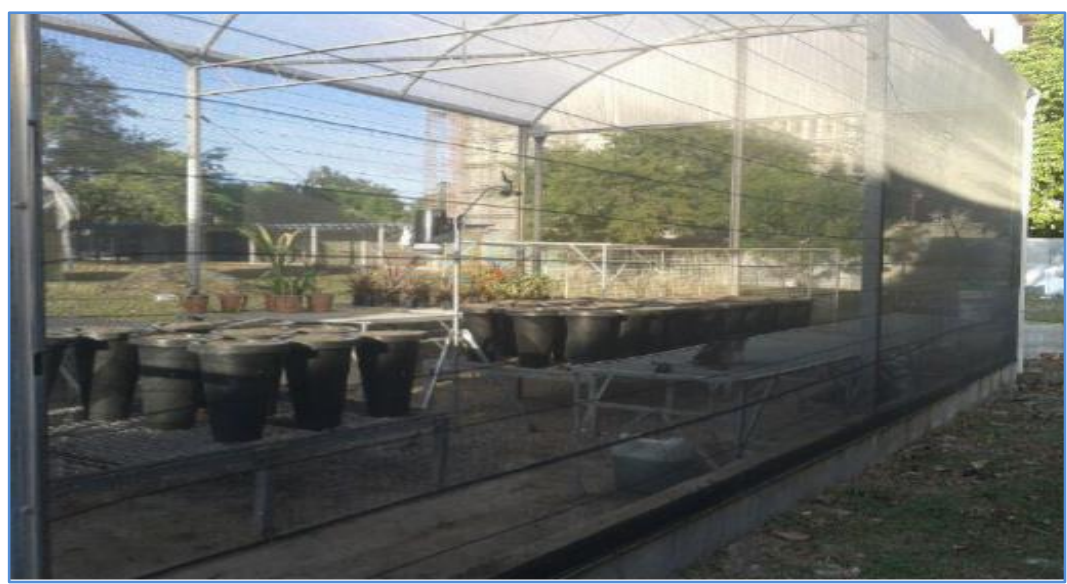

Fonte: Iasmine Dantas, 2014.

Foi realizado o preparo da casa de vegetação antes da semeadura, consistindo na remoção de gramíneas e ervas daninhas ao redor e abaixo das bancadas metálicas, com gadanhos para a obtenção de uma cultura limpa. A fim de se evitar alterações nas coletas dos dados agrometeorológicos, como por exemplo, da radiação solar, foi realizada a limpeza da parte superior da Casa de Vegetação.

O solo utilizado no experimento foi proveniente da fazenda experimental da Universidade Federal de Sergipe, o Campus Rural. 0 tipo de solo atendia as necessidades de ambas as culturas, arenoso-argiloso. A coleta foi realizada em novembro de 2013 e a profundidade utilizada na coleta foi de até 20 centímetros. Após a coleta o mesmo foi homogeneizado

Já na Casa de vegetação, o solo foi peneirado utilizando-se peneira de malha grossa. Em seguida, colocado nos vasos. (Figura 2). Foram utilizados vasos plásticos em formato de braço de cone (diâmetro superior de $29,0 \mathrm{~cm}$, diâmetro inferior de $16,5 \mathrm{~cm}$ e altura de $50 \mathrm{~cm}$ ), perfazendo um volume de $22,08 \mathrm{dm} 3$. Amostras de solo foram retiradas e enviadas para análise no Instituto Tecnológico de Pesquisa de Sergipe (ITPS). Após a análise, foi realizada calagem com o objetivo de se realizar as correções necessárias.

Figura 2: Preparo do solo

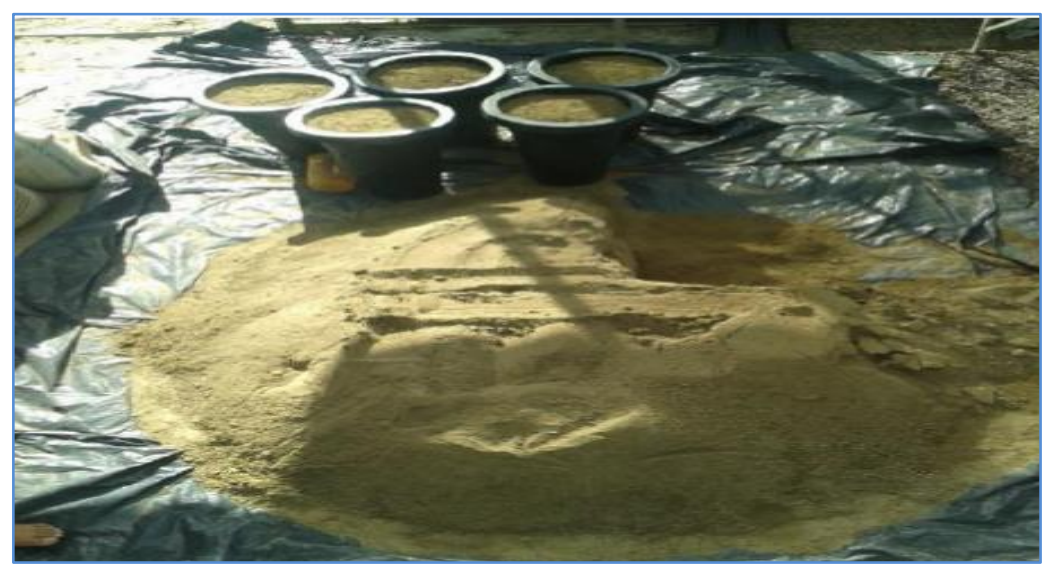

Fonte: Larissa Oliveira, 2013.

O delineamento experimental utilizado na etapa agronômica, foi em blocos casualizados (DBC), sendo utilizados 5 blocos. Os tratamentos foram constituídos por 2 espécies de hortaliças (cenoura e beterraba) e 4 percentuais de água tratada (DESO) e/ou água residuária (ETE) utilizado, totalizando 8 tratamentos conforme Figura 3. 
Figura 3 -Tratamento utilizados

\begin{tabular}{|lll|}
\hline Tratamento & Cultura & Percentual e água utilizada \\
\hline 1 & Cenoura & $100 \%$ Agua DESO \\
2 & Cenoura & $75 \%$ Agua DESO $+25 \%$ Água residuária \\
3 & Cenoura & $75 \%$ Agua residuária $+25 \%$ água DESO \\
4 & Cenoura & $100 \%$ Água Residuária \\
5 & Beterraba & $100 \%$ Agua DESO \\
6 & Beterraba & $75 \%$ Água DESO $+25 \%$ Água residuária \\
7 & Beterraba & $75 \%$ Água residuária $+25 \%$ água DESO \\
8 & Beterraba & $100 \%$ Agua Residuária \\
\hline
\end{tabular}

Fonte: Iasmine Dantas, 2014.

\subsection{LIMPEZA E MONTAGEM DA ESTAÇÃO METEOROLÓGICA E SISTEMA DE IRRIGAÇÃo}

A estação meteorológica automática foi instalada dentro da casa de vegetação no dia 22 de janeiro de 2014 (Figura 5) antes da instalação do experimento. Após a instalação realizou-se a limpeza dos sensores utilizando flanela e água. A demanda evapotranspirométrica de referência no interior da casa de vegetação foi estimada diariamente, utilizando-se o método padrão FAO 56 Penman-Monteith.

As variáveis necessárias para o método FAO 56 (temperatura, umidade relativa, radiação solar e velocidade do vento) foram obtidas diariamente através da estação meteorológica automática. Para a estimativa da evapotranspiração da cultura, utilizou-se o produto da evapotranspiração de referência (ET0) e do coeficiente de cultura (Kc). 0 coeficiente de cultura foi obtido no boletim FAO 56.

A água DESO e a água residuária foram distribuídas sobre os tratamentos por meio de proveta de $100 \mathrm{ml}$ diretamente no vaso, semelhante a uma irrigação por superfície.

\subsection{ESTAÇÃO DE TRATAMENTO DE ESGOTO (ETE) E COLETA DA ÁGUA RESIDUÁRIA}

A água residuária utilizada no experimento foi proveniente da Estação de Tratamento de Esgotos localizase no Bairro Rosa Elze em São Cristóvão, Sergipe. A ETE Rosa Elze foi construída na década de 80 e mantida e operada pela DESO e é responsável pelo tratamento dos esgotos provenientes dos bairros Rosa Elze e Eduardo Gomes, atuando com vazão aproximada de 7,6 L.s-1, composta por cinco lagoas de estabilização disposta em série, sendo duas facultativas e três de maturação perfazendo uma área total de 29.650 m2. Suas características físicas são descritas a seguir na Figura 4:

Figura 4 - Características físicas da ETE.

\begin{tabular}{|lccc|}
\hline \multicolumn{1}{|c}{ Lagoa } & Profundidade $(\mathrm{m})$ & Area $\left(\mathrm{m}^{2}\right)$ & Volume $\left(\mathrm{m}^{5}\right)$ \\
\hline Facultativa Primária & 2.00 & 8.735 & 17.470 \\
Facultativa Secundária & 1.98 & 6.962 & 13.785 \\
Maturação 1 & 1.96 & 4.712 & 9.236 \\
Maturação 2 & 1.94 & 4.618 & 8.959 \\
Maturação 3 & 1.92 & 4.623 & 8.876 \\
\hline
\end{tabular}

A ETE utilizada no estudo é alimentada pelo esgoto sanitário em dois pontos: um na lagoa facultativa primária, que representa a maior contribuição do sistema, segundo informações da DESO, recebendo o esgoto proveniente da estação elevatória; outro na lagoa facultativa secundária, que recebe o esgoto por 
gravidade. Em ambos os pontos, o esgoto chega à unidade de pré-tratamento, composto por grade e caixa de areia, sendo então encaminhado às lagoas.

Após tratamento, a água residuária foi coletada semanalmente da ETE da última lagoa e transportada até a Casa de vegetação através de recipientes plásticos de 20 litros. A água potável da DESO foi coletada e armazenada em reservatório de 500 litros, situado anexo à casa de vegetação. 0 quantitativo de coletas semanais se comportava de acordo com a necessidade hídrica, determinada em função da cada uma das quatro fases fenológicas da cultura, de acordo com a FAO (1998).

\subsection{SEMEADURA E CONDUÇÃO DO EXPERIMENTO}

A semeadura da cenoura e beterraba foi feita no dia 07 de abril de 2014 utilizando as variedades Alvorada Calibrada Média para cenoura e Híbrida Merlot para beterraba da marca Isla Sementes. Como procedimento fora colocada em fileira uma boa quantidade de sementes por vaso. Após semeadura, foi realizada a irrigação de saturação, até a germinação de todas as sementes, composta por $400 \mathrm{ml}$ de água potável da DESO duas vezes por dia, buscando a possibilidade de germinações uniformes e um bom desenvolvimento radicular das plântulas.

A partir do dia 30 de abril quando a germinação em todos os vasos ocorreu de forma satisfatória e todos os desbastes necessários foram feitos para que cada vaso ficasse com apenas quatro plantas, começou a irrigação diferenciada por tratamentos, com água da DESO e efluente. No momento da semeadura foi feita a adubação de plantio, de acordo com análise do solo, na qual todos os tratamentos receberam ureia (N), MAP (P205) e cloreto de potássio (K20) nos valores de 0,311 g/vaso de ureia, 5,1 g/vaso de MAP e 1,39 g/vaso de cloreto de potássio.

Após aproximadamente 30 dias da semeadura, foi realizada a adubação de cobertura no tratamento 1 (irrigado com 100\% água DESO). Foi aplicada parceladamente, com 30 e 50 dias após plantio, utilizandose ureia e cloreto de potássio, nos valores de 0,7 g/vaso de ureia e 0,4 g/vaso de cloreto de potássio para cenoura e 0,311 g/vaso de ureia, 4,4 g/vaso MAP e 1,5 g/vaso de cloreto de potássio para beterraba. (Figura 5 e 6)

Figura 5 - Desbaste da beterraba após 35 dias de semeadura

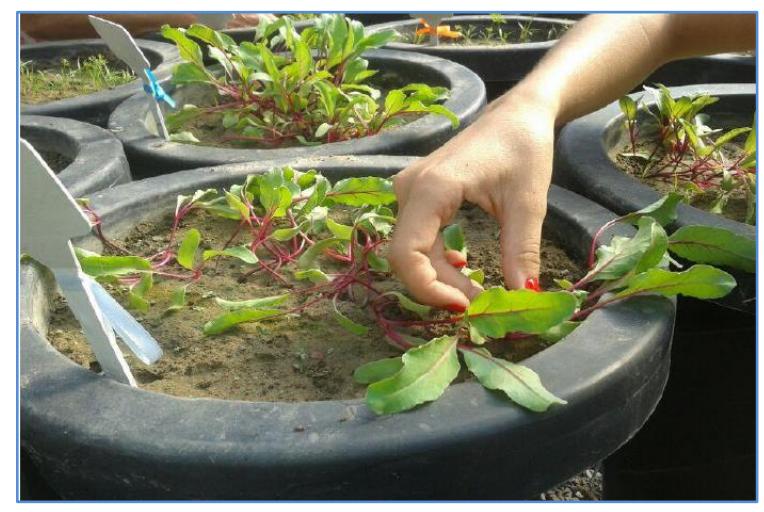

Figura 6 - Desbaste da cenoura após 35 dias de semeadura

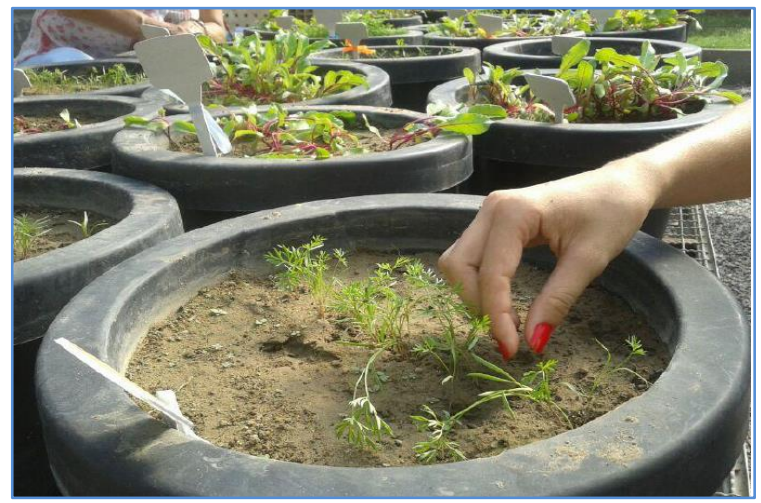

Fonte: Larissa Oliveira, 2014.

\subsection{PRAGAS, DOENÇAS E COLHEITA}

Observou-se na cultura da beterraba o aparecimento da doença cercosporiose e como forma de erradicação pulverizou-se o fungicida Score 250EC do grupo triazol após 51 e 58 dias da semeadura. Ambas apresentaram ao longo do experimento, infestação de lagartas. As mesmas foram retiradas manualmente e nenhum dano foi causado às culturas.

Após 104 dias a beterraba foi colhida (Figura 5). As plantas foram lavadas em água corrente, secas, armazenadas em sacos com zíper e congeladas no laboratório de Biotecnologia localizado no 
Departamento de Tecnologia de Alimentos da UFS para serem analisadas microbiologicamente. A cenoura (Figura 6) foi colhida 106 dias após a semeadura e foi realizado o mesmo procedimento de armazenamento da beterraba.

Figura 5 - Colheita da beterraba após 104 dias da semeadura.

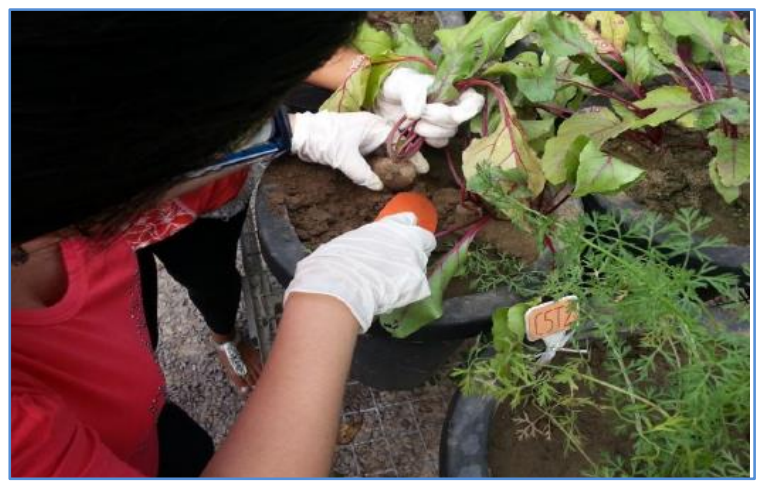

Figura 6 - Colheita da cenoura após 106 dias da semeadura.

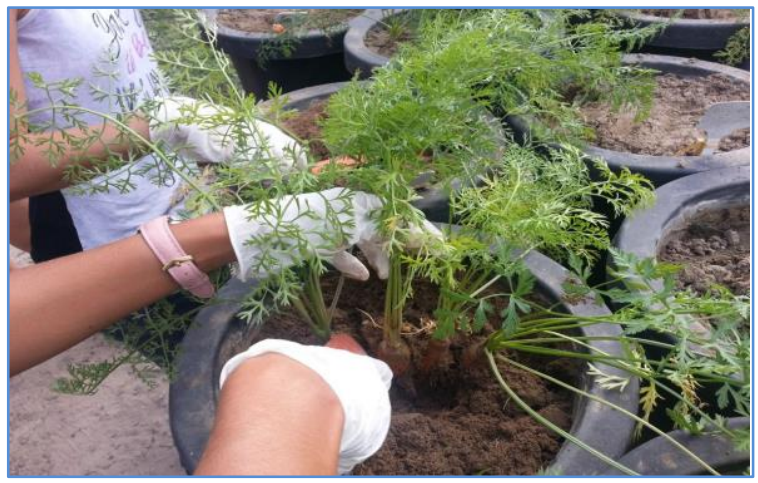

Fonte: Iasmine Dantas, 2014.

\subsection{ANÁLISE DA ÁGUA RESIDUÁRIA TRATADA E DA ÁGUA DESO}

As amostras de água DESO e água residuária foram coletadas no período de 11/03/2014 a 11/07/2014, em recipientes padronizados, adotando os procedimentos do Instituto Tecnológico e de Pesquisa de Sergipe (ITPS) para realização das análises.

Foram realizadas dois tipos de análises físico-químicas para cada tipo de água: parcial e total. Sendo cinco análises parciais e três totais. Nas análises parciais da água apenas pH foi analisado. As parciais da água residuária foram compostas por $\mathrm{pH}$ e fósforo total (P). Nas análises completas de água DESO e residuária os parâmetros verificados foram Demanda Bioquímica de Oxigênio (DBO), pH e fósforo total. Nas microbiológicas da água DESO e da residuária foram feitas análises de coliformes totais e Escherichia coli.

As análises realizadas seguiram o método descrito no Standard Methods for the Examination of Water and Wastewater (APHA, 2012).

As análises microbiológicas foram realizadas no Laboratório de Biotecnologia no Departamento de Tecnologia de Alimentos da Universidade Federal de Sergipe.

Foram pesadas $25 \mathrm{~g}$ de cada amostra, totalizando 8 amostras referentes aos 8 tratamentos utilizados. As amostras foram transferidas assepticamente para frascos contendo $225 \mathrm{~mL}$ de água peptonada e em seguida foram preparadas diluições decimais até 10-6 em água peptonada 0,1\%. Foram feitas triplicatas de cada amostra.

Para a análise de coliformes termotolerantes, alíquotas de $1 \mathrm{~mL}$ de cada diluição $(10-1,10-2,10-3)$ foram inoculadas em séries de três tubos contendo $9 \mathrm{~mL}$ de Caldo Lactosado (Oxoid) posteriormente, os tubos foram incubados a $35^{\circ} \mathrm{C}$ por 48 horas em B.O.D. (ELETROlab®, Modelo EL101/3). Após esse período os tubos positivos (turvação e formação de gás), seguiram para os testes confirmativos. Com auxílio de uma alça de níquel cromo, uma alíquota foi retirada de cada tubo positivo de Caldo Lactosado e transferido para o Caldo E. Coli (EC - Oxoid), esses tubos foram incubados a $45^{\circ} \mathrm{C}$ por 48 horas em banho-maria. Os tubos que apresentavam turbidez e produção de gás foram considerados positivos (KORNACKI e JOHNSON, 2001).

\section{RESULTADOS E DISCUSSÃo}

Para beterraba de mesa, Allen et al. (1998) apresentam valores de kc de 0,50; 1,05 e 0,95, nas fases inicial, média e final, respectivamente. Os valores de kc para a cenoura utilizados no experimento foram 0,7 para a fase inicial, entre 0,7 a 1,05 para a fase do desenvolvimento da cultura, 1,05 na fase de meia estação e 1,05 a 0,95 na fase final. Na estimativa de kc para uma dada localidade, a evapotranspiração de referência 
(ET0) constitui um importante parâmetro, sendo o método de Penamn- -Monteith o método padrão da FAO (ALLEN et al., 1998).

A soma total da evapotranspiração de referência ao longo do ciclo foi de 162,5 mm. Dentro das condições do experimento, para a beterraba o valor máximo de ETPc foi de 2,63 mm ocorrido no dia 11 de junho, na fase de desenvolvimento vegetativo e o mínimo de $0,7 \mathrm{~mm}$ no dia 01 de maio. 0 consumo de água pela cultura da beterraba, representado pela ETPc foi de 160,85 mm em todo o seu ciclo. Conforme Tivelli et al. (2011), a água constitui cerca de $90,9 \%$ da parte aérea e $87,3 \%$ da raiz da cultura da beterraba, sendo a falta de água responsável pela queda drástica na produção desta hortaliça.

Para a cenoura, o maior valor de ETPc foi 2,73 mm ocorrido no dia 13 de junho de 2014, na fase de desenvolvimento vegetativo e o menor valor de $0,9 \mathrm{~mm}$, no dia 16 de julho na fase de maturação da cenoura. 0 consumo de água pela cultura, dada pela ETPc, foi de 163,43 mm em todo o seu ciclo. Segundo Marouelli et al (2007), a cultura é altamente sensível ao déficit hídrico e exigindo valores entre 350 a 550 $\mathrm{mm}$ por ciclo em cultivo aberto.

Segundo Faccioli (1998), o baixo valor da evapotranspiração potencial de culturas cultivadas em casa de vegetação justifica-se pelo fato da evapotranspiração de referência, em geral, ser menor que a verificada na parte externa, o que é atribuído, basicamente, à parcial opacidade da cobertura plástica, à radiação solar e à redução da ação dos ventos, que são os principais fatores da demanda evaporativa da atmosfera, embora a temperatura do ar e a umidade relativa, em alguns momentos, possam ser, respectivamente, maior e menor no interior da casa de vegetação do que a céu aberto, o que contribuiria para maior evapotranspiração. A diferença entre a evapotranspiração interna e externa varia de acordo com as condições meteorológicas; em geral, a evapotranspiração no interior fica em torno de 60 a $80 \%$ da verificada no exterior.

\subsection{ANÁLISE DA ÁGUA RESIDUÁRIA TRATADA E DA ÁGUA DESO}

A Figura 7 apresenta os resultados das análises físico-químicas da água DESO.

Figura 7 - Análises físico-químicas da água DESO.

\begin{tabular}{|cccc|}
\hline Data da coleta & DBO (mg. L. $\left.-\mathrm{O}_{2}\right)$ & $\mathrm{pH}$ & $\begin{array}{c}\text { Fósforo Total } \\
\left.\text { (mg. L }{ }^{-1} \mathrm{P}\right)\end{array}$ \\
\hline $11 / 03 / 14$ & 8,0 & 7,39 & $<0,034$ \\
$30 / 04 / 14$ & 0 & 7,69 & $<0,034$ \\
$21 / 05 / 14$ & -- & 7,37 & - \\
$30 / 05 / 14$ & -- & 7,48 & - \\
$06 / 06 / 14$ & -- & 7,55 & - \\
$13 / 06 / 14$ & 0,5 & 7,43 & - \\
$27 / 06 / 14$ & -- & 7,47 & - \\
$11 / 07 / 14$ & -- & 7,38 & - \\
\hline
\end{tabular}

Fonte: ITPS (2014) --: não foi realizada análise.

A Figura 8 apresenta os resultados das análises físico-químicas da água residuária.

Figura 8: Análises físico-químicas da água residuária.

\begin{tabular}{|lccc|}
\hline Data da coleta & $\mathrm{DBO}\left(\mathrm{mg} \cdot \mathrm{L}^{-1} \mathrm{O}_{2}\right)$ & $\mathrm{pH}$ & $\begin{array}{c}\text { Fósforo Total } \\
\left(\mathrm{mg}^{-1} \mathrm{P}\right)\end{array}$ \\
\hline $11 / 03 / 14$ & 102 & 8,66 & 3,24 \\
$30 / 04 / 14$ & 44 & 7,36 & 2,48 \\
$21 / 05 / 14$ & -- & 7,76 & 2,58 \\
$30 / 05 / 14$ & -- & 8,25 & 2,27 \\
$06 / 06 / 14$ & -- & 8,37 & 2,32 \\
$13 / 06 / 14$ & 1 & 7,69 & 4,6 \\
$27 / 06 / 14$ & -- & 7,69 & 2,19 \\
$11 / 07 / 14$ & -- & 7,68 & 1,94 \\
\hline
\end{tabular}

Fonte: ITPS (2014) --: não foi realizada análise. 
Segundo Lima et al. (2006), citado por Souza et al. (2015), um dos constituintes poluentes que caracteriza a qualidade da água utilizada na irrigação é a demanda bioquímica de oxigênio (DBO). A DBO mensura a quantidade de oxigênio necessária para oxidar a matéria orgânica biodegradável sob condições aeróbicas, ou seja, avalia a quantidade de oxigênio dissolvido (OD) em mg.L-1 de 02, que será consumido pelos organismos aeróbios ao degradarem a matéria orgânica. Portanto, a DBO é uma variável da qualidade da água que quantifica a poluição orgânica pela depleção do oxigênio, o que poderá conferir condição anaeróbica ao ecossistema aquático.

Observa-se nas Tabelas 3 e 4 que apenas os valores de DBO para a água DESO dos dias 30 de abril e 13 de junho e para água residuária do dia 13 de junho estão dentro dos padrões aceitáveis pela Resolução CONAMA no $357 / 2005$ que confere DBO 5 dias a $20{ }^{\circ} \mathrm{C}$ até $3 \mathrm{mg} . \mathrm{L}-102$ para classe 1 (um), água utilizada para abastecimento público, podendo assim ser utilizada para irrigação de hortaliças consumidas cruas.

O elevado valor na DBO do dia 11 de março da água DESO, no qual foi o primeiro procedimento de coleta de água a ser realizado, pode ter sido causado pela execução de algum procedimento não adequado no momento da coleta, contudo, foi devidamente analisado e tomadas as ações corretivas necessárias para que todas as coletas posteriores não resultassem a recorrência, tendo em vista que a água DESO é classificada como classe 1 (um) para abastecimento público.

De acordo com a Resolução CONAMA no 357/2005 para efeito do pH nas águas destinadas à irrigação, é recomendado valores entre 6 a 9. Portanto, pelos dados apresentados nas Tabelas 3 e 4, a água DESO e a água residuária estão dentro dos padrões aceitáveis para irrigação. As águas residuárias que apresentam uma elevada concentração do íon $\mathrm{H}+$, ou seja, $\mathrm{pH}$ baixo, são difíceis de serem tratadas biologicamente. Convém ressaltar que a importância do $\mathrm{pH}$ não consiste apenas nas reações biológicas e químicas existentes no tratamento de esgotos, mas quando as águas são utilizadas para irrigação, o fato do pH ser muito ácido ou muito básico pode acarretar em sérios problemas de nutrição e toxicidade para a cultura, bem como o surgimento de incrustações e até corrosões nos sistemas de irrigação (DUARTE, 2006).

A Figura 9 apresenta os resultados das análises microbiológicas da água DESO.

Figura 9: Análise microbiológica água DESO.

\begin{tabular}{|lcc|}
\hline Data da coleta & $\begin{array}{c}\text { Coliformes totais (NMP/100 } \\
\mathrm{mL})\end{array}$ & $\begin{array}{c}\text { Escherichia coli } \\
\text { (NMP/100 mL) }\end{array}$ \\
\hline $11 / 03 / 14$ & Ausência & Ausência \\
$30 / 04 / 14$ & Ausência & Ausência \\
$21 / 05 / 14$ & Ausência & Ausência \\
$30 / 05 / 14$ & Ausência & Ausência \\
$06 / 06 / 14$ & Ausência & Ausência \\
$13 / 06 / 14$ & Ausência & Ausência \\
$27 / 06 / 14$ & Presença & Ausência \\
$11 / 07 / 14$ & Ausência & Ausência \\
\hline
\end{tabular}

Fonte: ITPS (2015) Presença: não foi possível a quantificação.

A Figura 10 apresenta os resultados das análises microbiológicas da água residuária 
Figura 10: Análise microbiológica água residuária.

\begin{tabular}{|lcc|}
\hline Data da coleta & $\begin{array}{c}\text { Coliformes totais (NMP em 100 } \\
\mathrm{mL})\end{array}$ & $\begin{array}{c}\text { Escherichia coli (NMP em } \\
100 \mathrm{~mL})\end{array}$ \\
\hline $11 / 03 / 14$ & & Presença \\
$30 / 04 / 14$ & Presença & Presença \\
$21 / 05 / 14$ & Presença & Presença \\
$30 / 05 / 14$ & Presença & $1,3 \times 10^{4}$ \\
$06 / 06 / 14$ & $1,7 \times 10^{4}$ & Presença \\
$13 / 06 / 14$ & $1,7 \times 10^{4}$ & Presença \\
$27 / 06 / 14$ & $1,7 \times 10^{5}$ & Presença \\
$11 / 07 / 14$ & $5,4 \times 10^{5}$ & Presença \\
\hline
\end{tabular}

Fonte: ITPS (2015) Presença: não foi possível a quantificação.

Para o uso de água na irrigação a Resolução CONAMA no 357/2005 determina que a quantidade de coliformes termotolerantes não deva ser excedida um limite de 200 colifor-mes termotolerantes em 100 $\mathrm{mL}$ de $80 \%$ ou mais, de pelo menos seis amostras, coletadas durante o período de um ano, com frequência bimestral, a norma concede utilizar o E. coli em substituição ao parâmetro coliformes termotolerantes (BRASIL, 2005).

A Organização Mundial da Saúde - OMS (WHO, 2006) destaca a importância da qualidade biológica dos efluentes utilizados na irrigação, para que se diminua a probabilidade de propagação de patógenos, ocasionando diversas enfermidades, e recomenda que o efluente tratado contenha menos que $103 \mathrm{NMP}$ (Número Mais Provável) por $100 \mathrm{~mL}$ de coliformes termotolerantes e menos que 1 ovo de nematoide por litro para que esse efluente possa ser utilizado na irrigação irrestrita.

No dia 27/06 o resultado acusou a presença de coliformes totais na água DESO, porém não ocorreu a contagem dos coliformes totais, pois como a água DESO é considerada pelo ITPS como água potável o procedimento padrão apenas indica presença e ou ausência. Desconsiderando o dia 27/06, os resultados indicam o uso da água DESO na irrigação e impossibilitando do uso da água residuária por ultrapassar os valores aceitáveis. Quanto a Escherichia coli observou-se ausência nas amostras da água DESO e presença nas amostras de água residuária tratada.

\subsection{QUALIDADE MICROBIOLÓGICA DA CENOURA E DA BETERRABA}

Os resultados microbiológicos obtidos foram comparados com a legislação voltada à alimentação humana (Agência Nacional de Vigilância Sanitária - ANVISA). Pode-se observar que, todos os tratamentos utilizados encontraram-se dentro dos padrões ANVISA.

A Resolução RDC no 12 de 02/01/2001 (ANVISA, 2001) para hortaliças frescas, "in natura", inteiras, selecionadas ou não, com exceção de cogumelos preconiza a ausência de Salmonella em 25 gramas e a população máxima de 103 NMP g-1 de coliformes termotolerantes.

Conforme explicitado anteriormente e apresentado na Figura 11, não foi observada a presença de coliformes termotolerantes em nenhuma das hortaliças analisadas (população < 3,0 NMP.g-1. Assim como a população de coliformes termotolerantes, não foi encontrado Salmonella sp. em nenhuma amostra analisada na presente pesquisa. 
Figura 11: Coliformes termotolerantes e Salmonella sp.

\begin{tabular}{|lcc|}
\hline Tratamento & $\begin{array}{c}\text { Coliformes } \\
\text { Salmonella sp. }\end{array}$ & termotolerantes (NMP ${ }^{\text {g-l }}$ \\
\hline Beterraba $100 \%$ água DESO & $<3$ & Ausência \\
Beterraba $75 \%$ água DESO $+25 \%$ água residuária & $<3$ & Ausência \\
Beterraba $25 \%$ água DESO+75\% água residuária & $<3$ & Ausência \\
Beterraba $100 \%$ água residuária & $<3$ & Ausência \\
Cenoura $100 \%$ água DESO & $<3$ & Ausência \\
Cenoura $75 \%$ água DESO $+25 \%$ água residuária & $<3$ & Ausência \\
Cenoura $25 \%$ água DESO $+75 \%$ água residuária & $<3$ & Ausência \\
Cenoura $100 \%$ água residuária & $<3$ & Ausência
\end{tabular}

Fonte: Iasmine Dantas (2014)

Na cidade de Marrakesh, em Marrocos, a freqüente utilização de águas residuárias brutas na agricultura, sem tratamento prévio, tem levado à contaminação de lavouras de alface e salsa irrigadas por este sistema, detectando-se a presença de Salmonella sp (MELLOUL et al., 2001).

Porém, pesquisas desenvolvidas por Rego et al. (2005), com a irrigação da melancia com efluente tratado, mostraram, em todos os frutos testados, a ausência de salmonelas e baixos valores de coliformes fecais, independente dos sistemas de irrigação utilizado, atendendo, assim, os limites fixados pela Agência Nacional de Vigilância Sanitária (ANVISA, 2001). Logo, não foi verificado comprometimento da qualidade microbiológica dos produtos analisados, classificando-os aptos ao consumo humano.

As Figuras 12 e 13 apresentam os resultados das análises de mesófilos e bolores e leveduras da beterraba e cenoura, onde as letras iguais na mesma coluna não diferem significativamente pelo teste de Tuckey à $5 \%$ de probabilidade. Como todos os resultados obtidos estão abaixo de 109, que é normalmente encontrado nos trabalhos científicos, não foi realizada uma análise estatística mais detalhada.

Figura 12: Enumeração da população de mesófilos e bolores e leveduras da beterraba.

\begin{tabular}{|llc|}
\hline \hline Tratamento & \multicolumn{1}{c|}{ Mesófilos (UFC. $\mathbf{g}^{-1}$ ) } & Bolores e Leveduras (UFC. $\mathbf{g}^{-1}$ ) \\
\hline Beterraba 100\% água DESO & $1,3 \times 10^{6} \mathrm{a} 1$ & $4,5 \times 10^{6} \mathrm{a} 1$ \\
Beterraba 75\% água DESO $+25 \%$ água residuária & $3,5 \times 10^{5} \mathrm{a} 1$ & $1,5 \times 10^{6} \mathrm{a} 1$ \\
Beterraba 25\% água DESO+75\% água residuária & $1,7 \times 10^{6} \mathrm{a} 1$ & $6,5 \times 10^{5} \mathrm{a} 1$ \\
Beterraba 100\% água residuária & $1,8 \times 10^{6} \mathrm{a} 1$ & $3,5 \times 10^{6} \mathrm{a} 1$ \\
\hline
\end{tabular}

Fonte: Iasmine Dantas (2014). Letras iguais na mesma coluna não diferem significativamente pelo teste de Tukey a $5 \%$.

Figura 13: Enumeração da população de mesófilos e bolores e leveduras da cenoura.

\begin{tabular}{|llc|}
\hline \hline Tratamento & Mesófilos (UFC. g g $^{-1}$ ) & Bolores e Leveduras (UFC. \\
\hline Cenoura 100\% água DESO & $4,2 \times 10^{4} \mathrm{a} 1$ & $2,2 \times 10^{3} \mathrm{a} 1$ \\
Cenoura 75\% água DESO $+25 \%$ água residuária & $1,3 \times 10^{4} \mathrm{a} 1$ & $2,5 \times 10^{4} \mathrm{a} 1$ \\
Cenoura 25\% água DESO $+75 \%$ água residuária & $2,7 \times 10^{4} \mathrm{a} 1$ & $8,2 \times 10^{4} \mathrm{a} 1$ \\
Cenoura 100\% água residuária & $3,5 \times 10^{4} \mathrm{a} 1$ & $1,4 \times 10^{4} \mathrm{a} 1$ \\
\hline
\end{tabular}

Fonte: Iasmine Dantas (2014). Letras iguais na mesma coluna não diferem significativamente pelo teste de Tukey a $5 \%$. 
Portanto embora a água residuária estivesse fora dos padrões estabelecidos pela Legislação CONAMA número 357 de 2005 e pela OMS de 2006, observa-se que microbiologicamente, os vegetais encontram-se adequados para o consumo. Vale ressaltar que recomenda-se a higienização com cloro de qualquer hortaliça antes do consumo, possibilitando uma redução ainda maior da carga microbiana, embora não tenha sido detectado nenhum dos microrganismos analisados.

\section{CONCLUSÃO}

De acordo com os resultados do presente trabalho foi possível concluir que:

- A beterraba e a cenoura sob as condições estudadas podem ser utilizadas para a alimentação, visto que os resultados se encontraram dentro dos padrões sanitários aceitáveis para a alimentação humana;

- $\quad$ Assim pode ser utilizado para irrigação o tratamento composto de $100 \%$ água residuária visto que, não foram encontrados coliformes termotolerantes e Salmonella sp. e a população de mesófilos e bolores e leveduras não variou significativamente entre os tratamentos estudados;

- $\quad$ A água residuária utilizada nessa pesquisa encontra-se fora dos padrões preconizados pelo CONAMA e OMS para água de irrigação.

\section{REFERÊNCIAS}

[1] ALLEN, R. G.; PEREIRA, L. S.; RAES, D.; SMITH. M. Crop evapotranspiration Guidelines for computing crop water requirements. In: FAO Irrigation and Drainage Paper 56. Rome: FAO, 1998.

[2] APHA. American Public Health Association. Standard Methods for the Examination of Water and Wastewater. 22a EDIÇÃO. Washington, 2012.

[3] ASANO, T. et al. Water reuse, issues, technologies, and applications. New York: Metcalf \& Eddy/AECOM, eds., McGraw Hill, 2007.

[4] D’AGUILA, P.S. et al. Avaliação da qualidade de água para abastecimento público no município de Nova Iguaçu. Cad. Saúde Pública [online]. 2000, vol.16, n.3, pp. 791-798. ISSN 0102-311X. http://dx.doi.org/10.1590/S0102$311 X 2000000300027$.

[5] DUARTE, A. Reuso de água residuária tratada na irrigação da cultura do pimentão. Universidade de São Paulo, Piracicaba, 2006.

[6] EMBRAPA - Empresa Brasileira de Pesquisa Agropecuária. 2011, 10 de janeiro. Hortaliças em números. Disponível em http://www.cnph.embrapa.br/

[7] FACCIOLI, G. G. Determinação da evapotranspiração de referência e da cultura da alface em condições de casa de vegetação, em Viçosa, MG. Universidade Federal de Viçosa, 1998.

[8] FAO. Agricultural production, primary crops. Disponível em: <http://www.fao.org> Acesso em: 55 julho. 2014.

[9] FILGUEIRA, F.A.R. Novo manual de olericultura: agrotecnologia moderna na produção e comercialização de hortaliças. Viçosa: UFV. 2012. 421 p.

[10] FOLEGATTI, M.V.; SÁNCHEZ-ROMÁN, R.M.; COELHO, R.D.; FRIZZONE, J.A. Gestão dos recursos hídricos e agricultura irrigada no Brasil. São Paulo: Universidade de São Paulo, 2011, p.14-23. Disponível em: <http://www.abc.org.br/IMG/pdf/doc-807.pdf> Acesso em: 02 dez. 2013.

[11] FONTES, P.C.R. Olericultura: teoria e prática. Viçosa: UFV. 2005. 486 p.

[12] FRANCO, B.D.G.M.; LANDGRAF, M. Microbiologia de alimentos. São Paulo: Atheneu, 1996. 182 p.

[13] HESPANHOL, I. Potencial de reuso de água no Brasil: agricultura, indústria, municípios, recarga de aquíferos. Revista Brasileira de Recursos Hídricos - RBRH, Porto Alegre,ed. comemorativa, v. 7, n. 4, p. 75-97, dez. 2002.

[14] HESPANHOL, I. Potencial de reuso de água no Brasil: agricultura, indústria, município e recarga de aquíferos. In: MANCUSO, P. C. S. \& SANTOS, H. F. (editores). Reuso de água. Barueri-SP: Manole, p.37-95, 2003.

[15] KING, A.D.; MAGNUSON, J.A.; TOROK, T.; COODMAN, N. Microbial flora and storage quality of partially processed lettuce. Journal of Food Science, v.56, p.459-461, 1991.

[16] KORNACKI, J.L.; JOHNSON, J.L. Enterobacteriaceae, Coliforms, and Escherichia coli as quality and safety indicators. In: DOWNES, F.P.; ITO, K. Compendium of methods for the microbiological examination of foods. 4.ed. Washington: American Public Health Association, 2001. Cap.8, p.69-82. 
[17] MELLOUL, A.; HASSANI, L.; RAFOUK, L. Salmonella contamination of vegetables irrigated with untreated wastewater. World Journal of Microbiology and Biotechnology, v.17, n.2, p. 207-209, 2001.

[18] PAGANINI, W. S. Disposição de esgotos no solo (escoamento à superfície). São Paulo: Fundo Editorial da AESABESP, 1997.

[19] PELCZAR JR, M.J; CHAN, E.C.S.; KRIEG, N.R. Microbiologia: conceitos e aplicações. 2.ed. São Paulo: McGraw-Hill, 1997. V.2. cap.30, p.372-397: Microbiologia de alimentos.

[20] REGO, J. L. et al. Uso de esgoto doméstico tratado na irrigação da cultura da melancia. Revista Brasileira de Engenharia Agrícola e Ambiental, Campina Grande, v. 9, Suplemento, p. 155-159, 2005.

[21] RIBEIRO, M. S.; LIMA, L. A.; FARIA, F. H. DE. S.; REZENDE, F. C.; FARIA, L. do A. Efeitos de águas residuárias de café no crescimento vegetativo de cafeeiros em seu primeiro ano. Revista Engenharia Agrícola, v. 29, p. 569-577, 2009.

[22] ROSA, D. R. Q.; Resposta da cultura da cenoura á irrigação conduzida com diferentes métodos de manejo. Universidade Federal de Viçosa, julho de 2012.

[23] SANDRI, D.; MATSURA, E. E.; TESTEZLAF, R. Desenvolvimento da alface elisa em diferentes sistemas de irrigação com água residuária. Revista Brasileira de Engenharia Agrícola e Ambiental, v. 11, p. 17-29, 2007.

[24] SOUSA, J. T. et al. Reúso de água residuária na produção de pimentão (Capsicum annuum L.). Revista Brasileira de Engenharia Agrícola e Ambiental, v.10, n.1, p.89-96, 2006.

[25] SOUZA, A. M. D. S. et al. Qualidade da água DESO e água residuária proveniente do sistema de lagoas de estabilização. Revista Brasileira de Agricultura Irrigada v.9, no.1, p. 24 - 31, 2015

[26] TIVELLI, S. W.; FACTOR, T. L.; TERAMOTO, J. R. S.; FABRI, E. G.; MORAES, A. R. A.; TRANI, P. E.; MAY, A. Beterraba do plantio à comercialização. Campinas: Instituto Agronômico de Campinas, 2011. 51p. Boletim técnico IAC, 210

[27] VITTI, M.C.D.; KLUGE, R.A.; YAMAMOTTO, L.K.; JACOMINO, A.P. Comportamento de beterrabas minimamente processadas em diferentes espessuras de corte. Horticultura Brasileira, Brasília, v. 21, n. 4, p. 623-626, outubrodezembro 2003. 


\section{Capítulo 3}

Variações na qualidade da água e no estado trófico do Reservatório Macela no período de 2004 a 2014.

\section{Ivane Marcley Nascimento Sena \\ Adnívia Santos Costa Monteiro \\ José do Patrocínio Hora Alves}

Resumo: O Reservatório Macela, construído no período 1953-1957 através do barramento do Riacho Macela, está situado na cidade de Itabaiana, estado de Sergipe. Tem capacidade de 2,7×106 m3, profundidade média de 3,9 m e ocupa uma área de 14 $\mathrm{km} 2$. Neste trabalho, foram comparados os dados obtidos nos períodos seco e chuvoso dos anos de 2004, 2005, 2013 e 2014, com o objetivo de identificar possíveis variações significativas na qualidade da água durante os dez anos estudados. A qualidade da água do reservatório foi avaliada pela medida do $\mathrm{pH}$, condutividade, temperatura, transparência, cor, oxigênio dissolvido, clorofila a, sólidos totais dissolvidos, fósforo total, nitrato, nitrito, $\mathrm{N}$-amoniacal, fosfato e coliformes termotolerantes e pelo Índice do Estado Trófico (IET). Os parâmetros da qualidade da água que apresentaram variações significativas de 2004 a 2014 foram: pH $(7,3$ - 9,0), condutividade $(977,7-2940 \mu \mathrm{S} \mathrm{cm}$ 1), sólidos totais dissolvidos (547,5 - $1056 \mathrm{mg} \mathrm{L-1})$, oxigênio dissolvido $(3,38-11,23$ mg.L-1), nitrato $(0,01-2,38 \mathrm{mg} . \mathrm{L}-1)$, fosfato $(0,02-1,35 \mathrm{mg}$ L-1) e clorofila a $(22,8$ 163,2 $\mu \mathrm{g} \mathrm{L-1)}$. 0 IET indicou um ambiente hipertrófico em todo período estudado e a razão NID:P-P043- sugeriu que o nitrogênio é o nutriente limitante da produção algal. Os resultados da Análise de Componentes Principais e Análise Hierárquica indicaram que a qualidade da água das amostras coletadas em 2004 e 2005 são estatisticamente diferente das amostras coletadas em 2013 e 2014 e que, no período temporal de dez anos (2004 a 2014), ocorreu uma variação pequena, mas significativa na qualidade da água do reservatório, com redução nos valores do pH, condutividade, nitrato, fosfato e clorofila a. No entanto, o reservatório ainda se mantém hipereutrofizado e com salinidade elevada.

Palavras-chave: Estabilidade; Eutrofização; Lago Raso. 


\section{INTRODUÇÃO}

Reservatórios são lagos artificiais originados a partir do represamento de rios. Em geral, sua construção visa à regularização da vazão dos rios para obtenção de água em quantidade necessária para atender aos usos múltiplos. Contudo, o barramento transforma um ambiente lótico em lêntico, provocando desequilíbrios na estrutura hidrobiológica e físico-química do meio, gerando ambientes bastante instáveis, desencadeando alterações tanto no meio aquático quanto no terrestre, sendo primordial uma gestão eficiente destes, a fim de assegurar sua qualidade para atendimento dos usos múltiplos.

O número de pequenos reservatórios, ou açudes, como também são conhecidos, tem crescido muito nas últimas décadas e com isso, o estudo dessas pequenas estruturas tem se tornado cada vez mais importante (CARPENTER et al. 2011). Scheffer (2004) classifica como lago raso, corpos d'água com uma profundidade média de menos de $3 \mathrm{~m}$, e uma área de superfície variando de menos de um a mais de 10000 hectares. Lagos e reservatórios são sistemas ecologicamente muito diversos e variam grandemente em área e profundidade, inclusive, a profundidade é um dos parâmetros morfométricos de maior relevância limnológica (Cigana et al. 2014).

A intensa interação água-sedimento e o potencial impacto da vegetação aquática tornam os lagos rasos muito diferentes dos lagos profundos em vários aspectos (Scheffer (2004); Scheffer e Van Nes, (2007), por exemplo, no que diz respeito a influência da estratificação nesses sistemas. Lagos profundos são estratificados durante o período seco, o que resulta em uma troca pobre de nutrientes e oxigênio entre a zona fótica e o fundo do lago, entretanto, em lagos rasos a variação da temperatura não vai ser acentuada, por consequência, nem a densidade da água, não desencadeando assim, em camadas distintas ao longo do corpo d'água. Ou seja, diferente de lagos profundos, em lagos rasos a coluna d'água é frequentemente bem misturada, sendo referenciados como polimíticos (SCHEFFER, 2001).

Em particular, os reservatórios situados em áreas urbanas são especialmente submetidos a pressões devido aos serviços ecossistêmicos e sociais prestados por eles, estando mais susceptíveis a eventos de eutrofização. Um exemplo é o Macela, um reservatório raso situado na cidade de Itabaiana, Estado de Sergipe, que teve a qualidade das suas águas seriamente afetada pela ação antrópica, principalmente através do lançamento de efluentes sem tratamento, bem como, pela atividade agrícola no entorno do corpo d'água. As péssimas condições desse reservatório, tão importante para a atividade econômica da região, impulsionaram reiteradas ações do Ministério Público e dos Órgãos Ambientais visando a recuperação do reservatório que hoje encontra-se hipereutrofizado (SENA, 2017).

Deste modo, este trabalho procurou analisar através de informações de longo prazo (10 anos) a ocorrência de variações significativas na qualidade da água do Reservatório Macela a fim de oferecer um diagnóstico mais preciso a respeito dos eventos que levaram o reservatório a situação que se encontra hoje, oferecendo um suporte que auxilie as autoridades competentes na tomada de decisão no que tange a gestão do citado reservatório.

\section{MATERIAL E MÉTODOS}

\section{1 ÁREA DE ESTUDO}

O reservatório Macela (Figura 1) está situado na cidade de Itabaiana, Estado de Sergipe, no Nordeste do Brasil (latitude $10^{\circ} 40^{\prime} 8^{\prime \prime} \mathrm{S}$, longitude $37^{\circ} 24^{\prime} 35^{\prime \prime}$ ). Foi construído pelo DNOCS (Departamento Nacional de Obras Contra Seca), no período 1953-1957 através do barramento do Riacho Macela. A capacidade do reservatório é de 2,7x106 $\mathrm{m}^{3}$, ocupando uma área de $14 \mathrm{~km} 2$, sendo projetado para fornecer água para irrigação de 156 hectares (CARVALHO e COSTA, 2010; SANTOS, 2013).

A cidade de Itabaiana possui uma população estimada segundo IBGE (2019) de 95.427habitantes, com densidade demográfica de 258,30 hab.km- ${ }^{2}$, distribuídos em uma área de $336,7 \mathrm{~km}^{2}$, numa altitude $188 \mathrm{~m}$ e com uma precipitação média anual de 1300 mm (Santos, 2013; IBGE, 2010). A partir dos anos 80, com o crescimento sem planejamento da cidade de Itabaiana, o reservatório começou a receber efluentes domésticos e industriais sem tratamento, sendo que o grau de poluição começou a se agravar na década de 90, culminando com um evento de mortandade de peixes em março de 2009. 0 agravamento da situação ambiental do reservatório levou o Ministério Público Federal a autuar, como réus num processo de Ação Civil Pública, o Departamento Nacional de Obras Contra as Secas - DNOCS, o Município de Itabaiana, o Estado de Sergipe, a Companhia de Saneamento de Sergipe - DESO e a Administração Estadual do Meio Ambiente - ADEMA, responsabilizando-os sobre a situação do reservatório e exigindo providências para sua recuperação (MPF, 2013). 
Figura 1 - Reservatório Macela

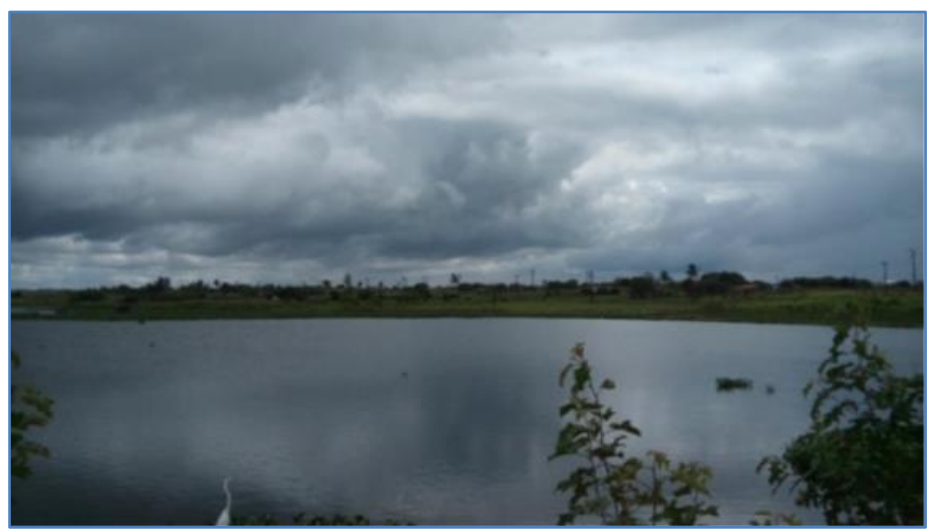

Fonte: Acervo Próprio (2015)

\subsection{AMOSTRAGEM E ANÁLISES}

Amostras de água foram coletadas no ponto 673.844 (E) 8.820 .262 (N) em períodos chuvosos e secos, dos anos de 2004, 2005, 2013 e 2014. As análises foram realizadas de acordo com as recomendações do Standard Methods (APHA, 2012). Por possuir uma coluna d'água homogênea e pequena profundidade, foi tomada apenas amostras da água de superfície. 0 quadro 1 apresenta as variáveis analisadas e métodos utilizados na determinação de cada parâmetro. Para garantia da qualidade analítica foi usado à calibração com padrões, a análise de reagentes em branco e determinações em replicatas.

Quadro 1 - Variáveis analisadas e métodos analíticos utilizados.

\begin{tabular}{|llc|}
\hline \multicolumn{1}{|c|}{ Parâmetros } & Técnica analítica & $\begin{array}{c}\text { Método de } \\
\text { referência }\end{array}$ \\
\hline $\mathrm{pH}$ & Método potenciométrico & SM 4500 H+ B \\
\hline Condutividade elétrica & Método condutimétrico & SM 2510 B \\
\hline Oxigênio dissolvido & Método de laboratório & SM 4500 0 \\
\hline Sólidos totais dissolvidos & Determinado pela medida da condutividade & SM 2510 A \\
\hline Transparência & Medida em campo & - \\
\hline Temperatura da água & Medida em campo & - \\
\hline Fósforo total & Método espectrofotométrico e ICP OES & SM 9223 B \\
\hline Coliformes termotolerantes & NMP Colilert 24 & US EPA 300.7 \\
\hline $\mathrm{N}$ - nitrato & Método espectrofotométrico e Cromatografia iônica & US EPA 300.7 \\
\hline $\mathrm{N}$ - nitrito & Método espectrofotométrico e Cromatografia iônica & US EPA 300.7 \\
\hline $\mathrm{N}$ - amoniacal & Método espectrofotométrico e Cromatografia iônica & US EPA 300.7 \\
\hline P- fosfato & Método espectrofotométrico e Cromatografia iônica & \\
\hline
\end{tabular}

\section{3 ÍNDICE DE ESTADO TRÓFICO - IET}

Para obtenção do IET, calculou-se uma média de valores de três índices obtidos separadamente mediante uma transformação linear da profundidade do Disco de Secchi [IET(DS)] e das concentrações de Fósforo Total [IET(Pt)] e Clorofila a [IET(Cla)] (Toledo, 1990). Neste estudo, para obtenção do IET foram utilizados as equações propostas por Carlson (1977), Toledo (1990) e (Lamparelli, 2004), demonstradas a seguir. 
- Carlson (1977)

$$
\begin{aligned}
& \operatorname{IETC}(D S)=10\left(6-\frac{\ln D S}{\ln 2}\right) \\
& \operatorname{IETC}(P t)=10\left(6-\frac{\ln \left(\frac{48}{P t}\right)}{\ln 2}\right) \\
& \operatorname{IETC}(C l a)=10\left(6-\frac{2,04-0,68 \ln C l a}{\ln 2}\right)
\end{aligned}
$$

- $\quad$ Toledo (1990)

$$
\begin{aligned}
& \operatorname{IETT}(D S)=10\left(6-\frac{0,64+\ln D S}{\ln 2}\right) \\
& \operatorname{IETT}(P t)=10\left(6-\frac{\ln \left(\frac{80,32}{P t}\right)}{\ln 2}\right) \\
& \operatorname{IETT}(C l a)=10\left(6-\frac{2,04-0,695 \ln C l a}{\ln 2}\right)
\end{aligned}
$$

- $\quad$ Lamparelli, 2004

$$
\begin{aligned}
& \operatorname{IETL}(D S)=10\left(6-\left(\frac{\ln D S}{\ln 2}\right)\right) \\
& \operatorname{IETL}(C l a)=10\left(6-\left(\frac{0,92-0,34(\ln C l a)}{\ln 2}\right)\right) \\
& \operatorname{IETL}(P t)=10\left(6-\left(1,77-\frac{0,42(\ln P t)}{\ln 2}\right)\right)
\end{aligned}
$$

Onde DS é a profundidade do Disco de Secchi em metro; Pt a concentração do fósforo total em mg m-3; e Cla a concentração da clorofila a em mg m-3.

\subsection{ANÁLISE ESTATÍSTICA MULTIVARIADA}

Com o objetivo de avaliar a ocorrências de possíveis variações temporais na qualidade da água, no intervalo temporal do estudo, foi aplicada ao conjunto dos dados a Análise de Componentes Principais (ACP) e Análise Hierárquica (AH).

A ACP é uma técnica estatística aplicada para reduzir a dimensionalidade do conjunto de dados, que pode ser composto por um grande número de parâmetros da qualidade da água e pelas estações de amostragem, mantendo tanto quanto possível a confiabilidade dos dados originais. A redução é obtida transformando o conjunto de dados em novas variáveis, chamadas de componentes principais, as quais são ortogonais (não correlacionadas) e organizadas em ordem decrescente de importância (SINGH, 2004; SHRESTHA e KAZAMA, 2007). Muitas vezes um único ou poucos parâmetros da qualidade da água podem ser a principal fonte de variabilidade e nesse caso, a primeira componente principal será representada grandemente por esses parâmetros, levando as outras componentes principais a terem uma variância pequena ou desprezível. Para corrigi esse desvio, em vez de aplicar a ACP à matriz de covariância, tem sido usado a matriz de correlação, o que equivale à padronização das variáveis (KHALIL, 2009; WANG, 2012).

A AH é uma técnica exploratória que tem como finalidade agrupar objetos com base nas suas similaridades, onde a variância dentro do grupo é minimizada e entre grupos maximizada (Everitt, 2011). A AH foi aplicada ao conjunto dos dados com o objetivo de agrupar as campanhas de amostragem com base na similaridade da composição físico-química da água de cada campanha amostral. Os dados foram normalizados utilizando a técnica de z-score. Nessa técnica os dados normalizados possuem média igual a 0 e variância igual a 1 .

As análises estatísticas foram realizadas utilizando o programa PAST - Paleontological STatistics, Versão 3.04 (http://folk.uio.no/ohammer/past). Um valor- $\alpha$ de 0,05 foi adotado como o nível crítico para todos os testes estatísticos dando um nível de confiança de $95 \%$. 


\section{RESULTADOS E DISCUSSÃO}

\subsection{QUALIDADE DA ÁGUA}

0 reservatório é pouco profundo (média de 3,9 m e máxima de 12,8 $\mathrm{m}$ ) e apresentou uma coluna d'água homogênea. A Tabela 2 apresenta os resultados dos parâmetros de qualidade da água das amostras coletadas nos períodos chuvosos e secos dos anos de 2004, 2005, 2013 e 2014.

Tabela 2 - Parâmetros da qualidade da água do reservatório Macela, no período seco (SE) e chuvoso (CH)

\begin{tabular}{|c|c|c|c|c|c|c|c|c|}
\hline \multirow[t]{2}{*}{ Parâmetros/ Ano - período } & \multicolumn{2}{|c|}{2004} & \multicolumn{2}{|c|}{2005} & \multicolumn{2}{|c|}{2013} & \multicolumn{2}{|c|}{2014} \\
\hline & СH.04 & SE.04 & СH.05 & SE.05 & CH.13 & SE.13 & CH.14 & SE.14 \\
\hline $\mathrm{pH}$ & 8,3 & 8,5 & 8,4 & 9,0 & 8,4 & 7,8 & 7,9 & 7,3 \\
\hline Condutividade $(\mu \mathrm{S} \mathrm{cm}-1)$ & 1440 & 1620 & 2280 & 2940 & 2000 & 977,7 & 1185 & 1097 \\
\hline Oxigênio dissolvido (mg L-1) & 5,20 & 9,63 & 4,51 & 4,79 & 11,23 & 3,38 & 5,65 & 5,66 \\
\hline Clorofila-a ( $\mu \mathrm{g} \mathrm{L-1})$ & 156 & 77,4 & 50,2 & 163,2 & 55,9 & 22,8 & 56,9 & 26,0 \\
\hline $\begin{array}{l}\text { Sólidos totais dissolvidos (mg L- } \\
\text { 1) }\end{array}$ & 884,0 & 888,0 & 1056 & 827,0 & 1380 & 547,5 & 817,9 & 614,0 \\
\hline Temperatura da água $\left({ }^{\circ} \mathrm{C}\right)$ & 27,0 & 30,0 & 32,1 & 28,0 & 26,0 & 25,0 & 27,0 & 28,0 \\
\hline Transparência (m) & 0,55 & 0,30 & 0,50 & 0,50 & 0,23 & 0,38 & 0,30 & 0,22 \\
\hline Fósforo total (mg L-1) & 0,71 & 0,65 & 0,90 & 1,35 & 1,64 & 1,20 & 2,48 & 1,48 \\
\hline N-N03- (mg L-1) & 1,30 & 2,38 & 1,11 & 0,95 & 0,59 & 1,31 & 0,01 & 2,02 \\
\hline N-NO2-(mg L-1) & 0,11 & 0,18 & 0,05 & 0,41 & 0,43 & 0,02 & 0,02 & 0,02 \\
\hline N- NH3(mg L-1) & 0,01 & 0,05 & 0,01 & 0,03 & 0,01 & 0,01 & 0,08 & 0,16 \\
\hline P-P043- (mg L-1) & 0,56 & 0,65 & 0,94 & 1,35 & 0,42 & 0,66 & 0,02 & 0,46 \\
\hline $\begin{array}{l}\text { Coliformes Termotolerantes } \\
\text { (NMP } / 100 \mathrm{~mL} \text { ) }\end{array}$ & 460 & 1600 & 420 & 520 & 4900 & 540 & 450 & 7000 \\
\hline
\end{tabular}

Como citado anteriormente, este é um reservatório raso, fato que contribui para que apresente uma coluna d'água homogênea, com pouca ou nenhuma variação da temperatura e, portanto, não deve apresentar eventos de estratificação térmica. A temperatura da água exerce influência sobre a atividade biológica e o crescimento de organismos aquáticos. Em geral, quanto maior a temperatura da água maior a atividade biológica, contudo, o aumento da temperatura diminui a solubilidade de gases a exemplo do oxigênio dissolvido. As temperaturas variaram de 25,0 a $32,1^{\circ} \mathrm{C}$ com uma média de $27,9 \pm 2,3^{\circ} \mathrm{C}$.

0 oxigênio dissolvido (OD) depende da atividade fotossintética e da decomposição microbial da matéria orgânica. 0 seu decréscimo em geral, indica um aumento nas condições eutróficas do corpo d'água (Sheela, 2011). O OD em torno de 4 a $5 \mathrm{mg} \mathrm{L-1}$ pode levar a morte de espécies de peixes mais exigentes, enquanto, ao atingir valores de $2 \mathrm{mg} \mathrm{L}-1$ ou abaixo disso, pode levar a mortandade dos peixes (SCHEFFER, 2001). Os valores de OD variaram de 3,38 a 11,23 mg L-1 com valor médio de 6,26 $\pm 2,71 \mathrm{mg} \mathrm{L-1}$. 0 menor e maior valor do OD foram registrados em 2005, nos períodos seco e chuvoso, respectivamente. A Resolução brasileira, mais especificadamente a Resolução CONAMA 357/2005 (BRASIL, 2005) estabelece para corpos hídricos de água doce, enquadrados na Classe 2, que os valores de OD não devem ser inferiores a 5 mg L-1, sendo assim, as amostras coletadas no ano de 2005 e no período seco de 2013, não atenderam ao valor limite de OD indicado pela legislação. Utilizou-se como referência para enquadramento do reservatório a classificação "Águas Doces Classe 2" pelo fato da Resolução CONAMA 357/2005 defininir em seu Art. 42 que enquanto não aprovado os respectivos enquadramentos, as águas doces serão consideradas classe 2 .

$\mathrm{O} \mathrm{pH}$ da água variou de 7,3 a 9,0 com valor médio de 8,2 $\pm 0,5$ e ficou dentro do intervalo (pH 6 a 9) estabelecido pela citada Resolução para águas doces de Classe 2 . A ocorrência de valores mais elevados de $\mathrm{pH}>$ 7, pode ser atribuída à perturbação do sistema ocasionado pela floração de algas ou macrófitas, que 
podem gerar o aumento da alcalinidade na água (Bucci e Oliveira, 2014). Segundo estes autores a floração de algas ou macrófitas no ambiente elevam o pH devido ao consumo de CO2 no processo de fotossíntese. Sendo assim, uma elevada proliferação de algas gera consumo de gás carbônico (acidez carbônica) durante a fotossíntese, o que acarreta na elevação do $\mathrm{pH}$ da água.

A condutividade elétrica estima a quantidade de sólidos totais dissolvidos ou a quantidade de íons totais dissolvidos na água e geralmente, aumenta à medida que aumenta a concentração dos sais dissolvidos, ou seja, à medida que aumenta a salinização do ambiente. Os valores da condutividade elétrica variaram de 977,7 a $2940 \mu \mathrm{S} \mathrm{cm}-1$ com um valor médio de $1693 \pm 675 \mu \mathrm{S} \mathrm{cm}-1$, enquanto as concentrações dos sólidos totais dissolvidos apresentaram uma variação de 547,5 a 1056 mg L-1 e uma média de 876,8 $\pm 258,8$ mg L1.

A condutividade elétrica tem sido utilizada para determinação do grau de salinidade através do diagrama de Richards (Delgado, 2010). Com isso, foi possível determinar que a água do reservatório Macela já se encontra em condições de alta a muito alta salinidade, o que restringe significativamente o seu uso para irrigação.

Gomes (2004), em seu estudo, concluiu que a água do reservatório Macela, não obedeceu aos padrões determinados pela legislação para Classe 2 no que se refere aos coliformes totais e termotolerantes, $\mathrm{pH}$, DBO, sólidos totais dissolvidos, cloretos, cor, amônia e fosfato. Bem como, considerou como sendo imprópria para irrigação devido à alta concentração de coliformes e elevada salinidade.

A transparência medida pelo Disco de Secchi é uma indicação da penetração de luz na coluna d'água e fornece uma medida indireta do material suspenso na água, podendo também ser uma indicação da quantidade de algas na água (SHEELA, 2011). A baixa transparência afeta, inclusive, os peixes, dificultando a sua alimentação (Straskraba e Tundisi, 2013) bem como, em águas turvas, é comum a ausência de vegetação, uma vez que a luz não consegue penetrar na coluna d'água e as plantas não tem a energia luminosa necessária para realizar a fotossíntese. Os valores do Disco de Secchi variaram entre 0,22 a 0,60 m com média de $0,38 \pm 0,10$ m e não atingiu o fundo da coluna d'água durante o período do estudo. Sheela et al. (2011), estudando lagos rasos hipereutróficos, também obteve uma baixa transparência medida através do Disco Secchi, não obtendo médias superiores a 0,35 m. Através dos dados de qualidade da água deste Reservatório, verifica-se que a alta turbidez é fortemente influenciada pela elevada densidade de organismos planctônicos, não sendo apenas resultante do material em suspensão.

A medida da concentração de coliformes termotolerantes é um indicador extensamente usado para avaliar o grau de poluição fecal em ambientes aquáticos. Os esgotos domésticos são as principais fontes de contaminação em sistemas aquáticos localizados em regiões urbanas e contém além dos excrementos humanos, um grande número de compostos orgânicos resultantes da atividade humana (ALVES, 2016). As concentrações de coliformes termotolerantes variaram no intervalo de 420 - 7000 NMP.100 mL-1. Valores acima de 1.000 NMP.100 mL, limite máximo estabelecido pela Resolução CONAMA 357/2005, para águas doces Classe 2, ocorreram nas amostras SE.05, CH.13 e SE.14, conforme Tabela 02.

O nitrogênio pode ser encontrado na água nas formas de nitrogênio orgânico, amoniacal (NH3 e N-NH4), nitrito (NO2) e nitrato (NO3). 0 nitrato é a forma mais comum de nitrogênio combinado encontrado em águas naturais não poluídas. O nitrogênio amoniacal usualmente tem concentração elevada em águas poluídas, como produto da decomposição da matéria orgânica. 0 nitrito é formado pela oxidação do nitrogênio amoniacal ou pela redução do nitrato. É uma forma instável e sua presença indica uma decomposição parcial da matéria orgânica da água (SHEELA, 2011).

Na água do reservatório Macela predominou a forma oxidada do nitrogênio (NO3) com concentrações

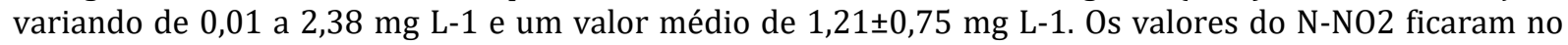

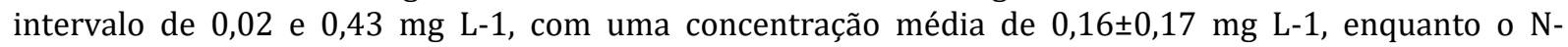

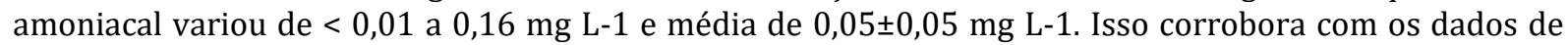
coliformes termotolerantes, indicando um ambiente impactado por despejos sanitários e em condições de decomposição parcial da matéria orgânica.

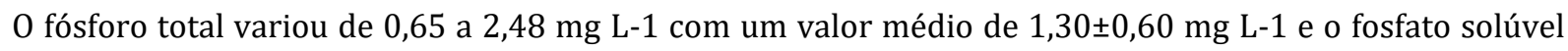
reativo (P04) variou de 0,02 a 1,35 mg.L-1, com uma concentração média de $0,63 \pm 0,39 \mathrm{mg}$ L-1. 0 fósforo total apresentou valores muito superiores ao limite estabelecido pela Resolução CONAMA 357/05 para águas doces Classe 2, que é de 0,030 mg L-1, em ambientes lênticos. Despejos sanitários contêm elevados teores de compostos de fósforo, e esses valores tem aumentado com o uso de detergentes a base de polifosfatos. Grande parte do fósforo inorgânico é resultante da degradação metabólica de proteínas e fosfatos liberados na urina (SHEELA , 2011). 
$\mathrm{O}$ aporte antropogênico de nutrientes, especialmente $\mathrm{N}$ e $\mathrm{P}$, denominada eutrofização cultural, permanece ainda como uns dos principais problemas nos ecossistemas de água doce (Schindler, 2006; Heisler, 2008; Glibert, 2014). A eutrofização tem efeitos nocisos sobre os ecossistemas aquáticos, incluindo aumento da biomassa de algas, depleção de oxigênio e o desenvolvimento de algas potencialmente tóxicas (Smith e Schindler, 2009). A clorofila a possibilita o entendimento do nível trófico do corpo d'água, uma vez que ela é uma forte indicadora da disponibilidade da biomassa fitoplanctônica e do efeito do enriquecimento de nutrientes (FRAGOSO et al. (2007); ZHANG et al. (2015); SMITH et al. 2006). A concentração de clorofila a

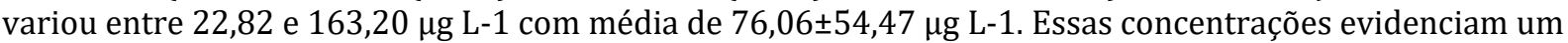
ambiente eutrofizado com elevada presença algal (SENA, 2017; LAMPARELLI, 2004).

As algas assimilam, preferencialmente, o fósforo na forma de fosfato livre Pandey e Parveen, (2011) e o nitrogênio nas formas amoniacal e nitrato (GLIBERT et al. 2014). Considerando que as concentrações de nitrogênio amoniacal foram muito baixas, a variação da disponibilidade de nutrientes e da produção algal, no periodo amostal, são mostradas na Figura 2 usando apenas as concentrações de NO3 e PO4, e valores da clorofila a. As linhas inclinadas indicam uma tendencia decrescente na disponibilidade de nutrientes e consequentemente na produção algal medida pela clorofila a. Apesar disso, de acordo com SENA (2017), o reservatório continua ainda hipereutrofizado.

Figura 2 - Distribuição do nitrato (N-NO3), fosfato (P-PO4) e clorofila a, nos períodos chuvoso (CH) e seco (SE), e linhas de tendência de 2004 a 2014
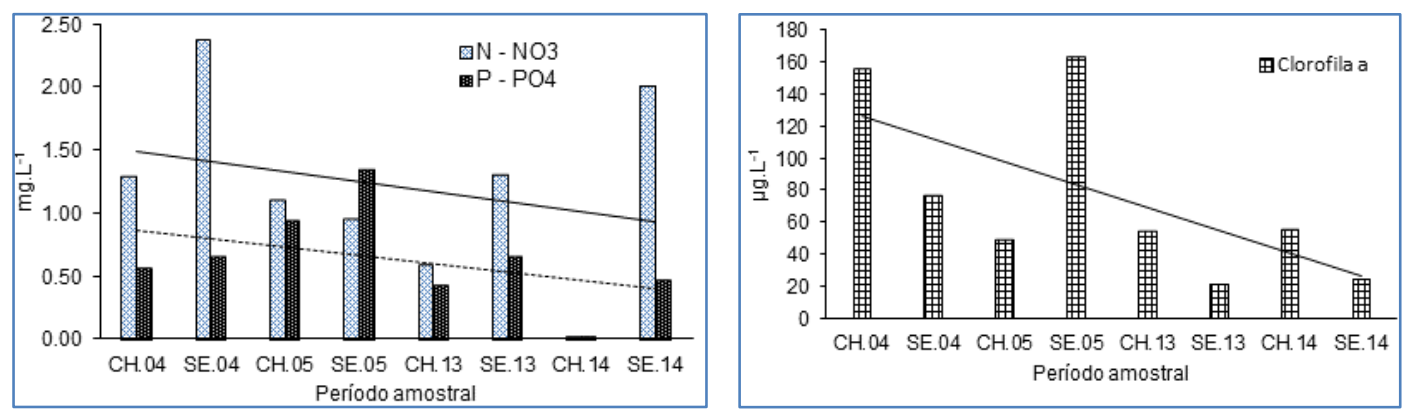

Fonte: Próprio Autor (2018)

Para evidenciar as limitações por nitrogênio ou fósforo foram utilizadas as razões NID:P-PO4, onde NID = $\mathrm{N}-\mathrm{NO} 3+\mathrm{N}-\mathrm{NO} 2+\mathrm{N}-\mathrm{NH} 3$. Uma relação NID/P-PO4 maior que 10, indica o fósforo como nutriente limitante, enquanto que uma relação inferior a 10, sugere o nitrogênio como nutriente limitante. Para o açude Macela as razões NID:P-P04-3 tiveram valores médios de 3,0 $\pm 1,7$ sugerindo o nitrogênio como nutriente limitante da produção algal. Howarth e Marino (2006) apresentaram uma ligação entre a alta salinidade e limitação do corpo d'água pelo nitrogênio. Esse fato é atribuído, em parte, a dificuldade de desenvolvimento das cianobactérias fixadoras de nitrogênio em ambientes com salinidade mais elevada. A salinidade no açude Macela, segundo o diagrama de Richards, como citado anteriormente, é considerada de alta a muito alta, apresentando valores médios de condutividade elétrica de 1692,5 $\mu \mathrm{S} \mathrm{cm-1.}$

\section{2 ÍNDICE DO ESTADO TRÓFICO}

O excessivo crescimento de algas promovido pela eutrofização altera a qualidade da água reduzindo a vida útil dos reservatórios. Von Sperling (2005), enumera que dentre os principais efeitos indesejáveis da eutrofização estão: problemas estéticos e recreacionais; condições anaeróbias no fundo do corpo d'água; mortandades de peixes; maior dificuldade e elevação nos custos de tratamento de água para abastecimento industrial e doméstico; redução na navegação e capacidade de transporte. Açudes urbanos, caso do açude Macela, tendem a estarem mais susceptíveis a eutrofização devido aos serviços ecossistêmicos e sociais prestados pelos mesmos.

O Índice do estado Trófico (IET) foi desenvolvido por Carlson (1977) e posteriormente, outros autores fizeram adaptações a esse método (a exemplo de Toledo, (1990) e Lamparelli, (2004)) visando uma melhor adequação ao clima tropical/subtropical, uma vez que o índice foi inicialmente desenvolvido para países de clima temperado. Sendo assim, é comumente usado na classificação trófica das águas de 
superfície, ocorrendo sua obtenção mediante o cálculo da média dos valores dos índices de Disco de Secchi [IET(DS)] e das concentrações de Fósforo Total [IET(Pt)] e Clorofila a [IET(Cla)], obtidos separadamente. As classificações são baseadas nos valores limites do IET para classes preestabelecidas a depender de cada equação, basicamente, entre quatro níveis: oligotrófico (pobre em nutrientes), mesotrófico (moderado em nutrientes), eutrófico (quantidade elevada de nutrientes) e hipertrófico (quantidade excessiva de nutrientes).

A Tabela 3 apresenta os valores dos IET(DS), IET(Pt), IET(Cla) para as metodologias propostas tanto por Carlson (1977), quanto por (TOLEDO, 1990) e (LAMPARELLI, 2004).

Tabela 3 - Valores de IET e NID:P-P04 para o Reservatório Macela

\begin{tabular}{|c|c|c|c|c|c|c|c|c|c|}
\hline \multicolumn{10}{|c|}{ Índice de Estado Trófico } \\
\hline \multirow{2}{*}{$\begin{array}{c}\text { Parâmetro/Ano- } \\
\text { período }\end{array}$} & \multicolumn{2}{|c|}{2004} & \multicolumn{2}{|c|}{2005} & \multicolumn{2}{|c|}{2013} & \multicolumn{2}{|c|}{2014} & \multirow{2}{*}{$\begin{array}{c}\text { IET } \\
\text { Hipereutrófico }\end{array}$} \\
\hline & $\mathrm{CH}$ & SE & $\mathrm{CH}$ & SE & $\mathrm{CH}$ & SE & $\mathrm{CH}$ & $\mathrm{SE}$ & \\
\hline IETC (Cla) & 80,11 & 73,23 & 68,99 & 80,55 & 70,05 & 61,25 & 70,22 & 62,53 & \\
\hline IETC (Pt) & 98,87 & 97,59 & 102,29 & 108,14 & 110,95 & 106,44 & 116,91 & 109,46 & \\
\hline IETC (DS) & 68,62 & 77,37 & 70,00 & 70,00 & 81,2 & 73,96 & 77,37 & 81,84 & \\
\hline Média IETc & 82,53 & 82,73 & 80,42 & 86,23 & 87,40 & 80,55 & 88,17 & 84,61 & IET $>70$ \\
\hline IETT (Cla) & 81,2 & 74,18 & 69,83 & 81,65 & 70,92 & 61,93 & 71,09 & 63,24 & \\
\hline IETT (Pt) & 91,44 & 90,17 & 94,86 & 100,71 & 103,52 & 99,01 & 109,48 & 102,04 & \\
\hline IETT (DS) & 59,39 & 68,14 & 60,77 & 60,77 & 71,97 & 64,73 & 68,14 & 72,61 & \\
\hline Média IETt & 77,34 & 77,49 & 75,15 & 81,04 & 82,14 & 75,22 & 82,90 & 79,30 & IET >74 \\
\hline IETL (Cla) & 71,5 & 68,06 & 65,94 & 71,72 & 66,47 & 62,07 & 66,55 & 62,71 & \\
\hline IETL (Pt) & 82,08 & 81,55 & 83,52 & 85,97 & 87,15 & 85,26 & 89,66 & 86,53 & \\
\hline IETL (DS) & 68,62 & 77,37 & 70 & 70 & 81,2 & 73,96 & 77,37 & 81,84 & \\
\hline Média IETl & 74,07 & 75,66 & 73,15 & 75,90 & 78,27 & 73,76 & 77,86 & 77,03 & IET>67 \\
\hline
\end{tabular}

Como se observa na Tabela 03, os valores médios dos índices do Estado Trófico foram maiores que os limites estabelecidos pelas três metodologias para um ambiente hipertrófico, ou seja, o reservatório Macela, em todo período estudado, apresentou-se como hipertrófico.

As diferenças entre os valores dos IET permitem inferir sobre os fatores que limitam o crescimento do fitoplâncton e a composição do sistema lacustre (SHEELA et al., 2011). No reservatório Macela o IET(Pt) foi superior ao IET(DS) e IET(Cla) (Tabela 03), isso caracteriza um ambiente que tem o nitrogênio como limitante da biomassa algal, corroborando com o que foi obtido pela relação NID/P-PO4.

Ainda segundo Sheela et al. (2011), quando o IET(Cla) é substancialmente menor que o IET (Pt) existe um indicativo que há menos algas presente que o esperado com base em $\mathrm{Pt}$, e qualquer outro elemento pode ser o limitante da produção algal. Se o IET(Cla)<IET(DS), evidencia que o séston é dominado por partículas muito pequenas (abióticas) e a luz é também um possível limitador da produção algal.

Os elevados valores encontrados no reservatório Macela para as variáveis utilizadas na determinação do estado trófico demonstram a sua preocupante situação, apresentando, inclusive, valores bem superiores aos obtidos em estudos realizados em outros reservatórios, a exemplo do: Açude Gavião/CE - Oliveira et al. (2013); Reservatório de Ilha Solteira - (GARCIA et al. 2007); reservatório Orós-CE - (SANTOS et al. 2014); Lago Água Preta/PA - (SANTOS et al. 2013). Barbosa et al. (2019) em estudo, também no Reservatório Macela, concluiu que este não atende aos padrões de qualidade estabelecidos para as Classes 1, 2 e 3 de água doce, bem como, tem sua qualidade piorada no período chuvoso.

Os custos relativos ao tratamento de águas eutrofizadas e poluídas é quatro vezes maior que o requisitado para águas de fontes primárias limpas, bem como, a recuperação do reservatório é bastante lenta, sendo o 
grau de acumulação de fósforo nos sedimentos fundamental para determinação do intervalo de tempo necessário para essa recuperação, uma vez que ele é continuamente liberado dos sedimentos (STRASKRABA e TUNDISI, 2013).

Para efeito de comparação, apresenta-se na Figura 03 os IET calculados pelas metodologias de Carlson (IETC), Toledo (IETT) e Lamparelli (IETL), usando apenas a clorofila a e o fósforo total, e os respectivos valores médios (M).

Como já pontuado anteriormente, os IET calculados pela clorofila a tiveram os menores valores e não se notou diferença significativa (One-way ANOVA) entre as três metodologias. Os IET calculados pelo Pt foram maiores e estatisticamente diferentes dos IET calculados pela Clorofila a e apresentaram diferença significativa (One-way ANOVA) entre os valores obtidos pelas três metodologias, com uma variação na seguinte ordem IETC $(\mathrm{Pt})>\operatorname{IETT}(\mathrm{Pt})>\operatorname{IETL}(\mathrm{Pt})$.

Figura 03. Variação dos IET calculados pela clorofila a (Cla) e pelo fósforo total (Pt) e valores médios (M).

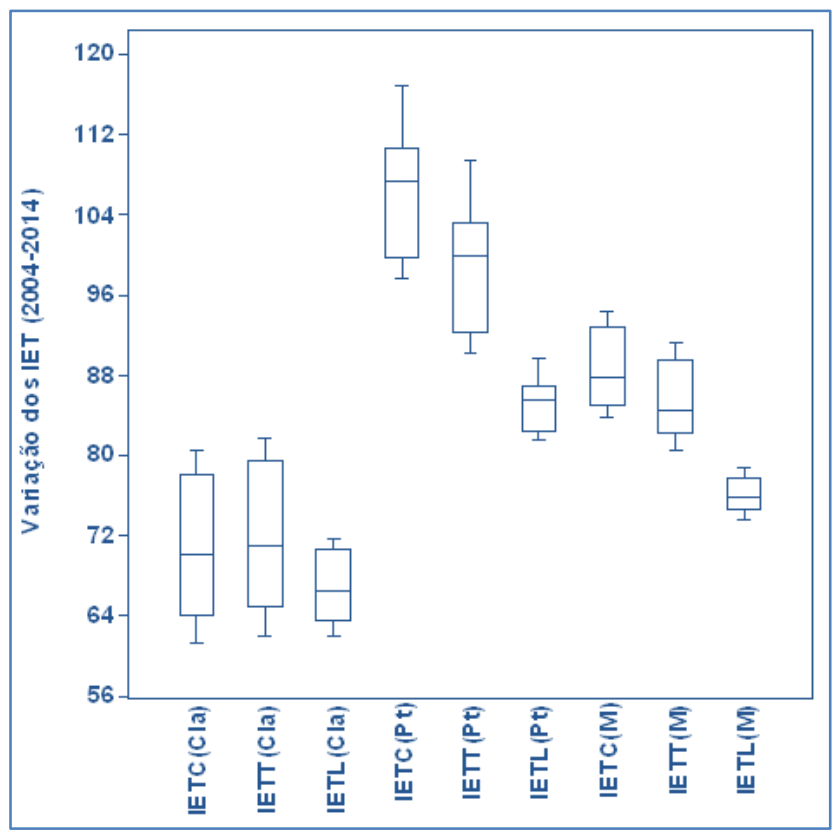

A metodologia de Lamparelli (2004) foi a que apresentou os menores valores médios [IETL(M)] e significativamente diferente dos resultados calculados pelas metodologias de Carlson [ITEC(M)] e Toledo [IETT(M)]. Os IETC(M) e IETT(M) não mostraram diferença significativa entre si (One-way ANOVA).

Ao inserir uma classificação trófica a mais, a metodologia proposta por Lamparelli apresenta uma amplitude maior na classificação trófica. Garcia (2007) inferiu em seu estudo no reservatório de Ilha Solteira, que o IETL apresentou maior sensibilidade às mudanças (obtendo classificações entre ultraoligotrófico e eutrófico), aumentando a amplitude das classificações tróficas, já o IETT apresenta uma amplitude numérica maior, podendo detectar concentrações menores (apresentou grau trófico entre oligotrófico e mesotrófico). Segundo o autor, como o reservatório tem a característica de possuir baixas concentrações de clorofila-a e fósforo total, o IETT é a metodologia que melhor se enquadra para uso nesse reservatório.

O Reservatório Macela não apresentou diferença de classificação quando analisado pelas diferentes metodologias. Esse fato pode ser atribuído as elevadas concentrações do fósforo total, da clorofila a e das baixas transparências (Disco Secchi) obtidas no reservatório. No caso do reservatório Macela, as concentrações de fósforo total e clorofila a são tão elevadas que seria preciso uma variação bem acentuada na concentração para ocorrer a mudança do estado trófico para outra classe. Nesse sentido, a metodologia que apresente uma amplitude numérica maior, seria mais adequada para o monitoramento do reservatório, por ser mais sensível as mudanças de variação na concentração. Sendo assim, as metodologias propostas por Carlson e Toledo, que não apresentaram diferença significativa entre si, são as que melhor se adequam a situação atual do reservatório. 
Na Tabela 04 é feita uma comparação entre as concentrações dos parâmetros clorofila-a, transparência e fósforo total, registradas no período de estudo, com os valores limiares indicados pelas três metodologias, para o enquadramento na classe hipertrófica. Os valores do fósforo total, em todo o período, ficaram acima dos limiares da classe hipertrófica. As transparências (Disco Secchi) encontram-se acima do valor limiar indicado pelas metodologias de Carlson e Toledo, desse com valores fora da faixa, e encontram-se abaixo do valor limiar proposto por Lamparelli.

Reservatórios rasos tendem a apresentar uma maior produtividade e níveis mais elevados de clorofila a Straskraba e Tundisi, (2013), todavia, no reservatório Macela, apenas nos períodos chuvoso de 2004 e seco de 2004 e 2005 que a concentração de clorofila-a se encontrou acima do limiar estabelecido para classe hipereutrófica, enquadrando-se assim, nesse período segundo essa classificação, na forma eutrófica e supereutrófica. Contudo, no cálculo do IET nas metodologias estudadas o reservatório foi enquadrado como hipereutrófico, não afetando significativamente essas variações no limiar.

Tabela 04. Comparação das concentrações de clorofila a, transparência e fósforo total com os valores limiar para a classe hipertrófica.

\begin{tabular}{|c|c|c|c|c|c|c|c|c|c|c|}
\hline \multirow{2}{*}{$\begin{array}{l}\text { Parâmetro/Ano- } \\
\text { período }\end{array}$} & \multicolumn{2}{|c|}{2004} & \multicolumn{2}{|c|}{2005} & \multicolumn{2}{|c|}{2013} & \multicolumn{2}{|c|}{2014} & \multicolumn{2}{|c|}{ Metodologia } \\
\hline & $\mathrm{CH}$ & SE & $\mathrm{CH}$ & SE & $\mathrm{CH}$ & SE & $\mathrm{CH}$ & SE & $\begin{array}{l}\text { Carlson e } \\
\text { Toledo }\end{array}$ & Lamparelli \\
\hline Clorofila a ( $\mu \mathrm{g} L-1)$ & 156,0 & 77,4 & 50,2 & 163,2 & 55,94 & 22,82 & 56,9 & 26,0 & Cla>76,1 & Cla $>69,05$ \\
\hline $\begin{array}{l}\text { Transparência do } \\
\text { DS (m) }\end{array}$ & 0,55 & 0,30 & 0,50 & 0,50 & 0,23 & 0,38 & 0,30 & 0,22 & $\mathrm{DS}<0,2$ & $\mathrm{DS}<0,6$ \\
\hline $\begin{array}{l}\text { Fósforo Total } \\
(\mu \mathrm{g} \mathrm{L}-1)\end{array}$ & 710 & 650 & 900 & 1350 & 1640 & 1200 & 2480 & 1480 & $\mathrm{Pt}>211,9$ & $\mathrm{Pt}>233,0$ \\
\hline
\end{tabular}

Lamparelli (2004) afirma que a CETESB não costuma empregar o IET baseado na transparência, uma vez, que essa é afetada pela elevada turbidez decorrente do material em suspensão comum em reservatórios e rios do Estado de São Paulo.Com isso, em alguns reservatórios, tem sido indicado a não utilização da variável transparência no cálculo do IET, uma vez, que essa variável pode não ser representativa para a determinação do estado trófico, pois, pode ser afetada pela elevada turbidez decorrente do material em suspensão e não apenas pela densidade de organismos planctônicos.

Considerando no cálculo médio do IET apenas o fósforo total (agente causador do processo) e a clorofila a (medida de resposta do corpo hídrico ao agente causador representando o nível de crescimento algal), a classificação trófica para o reservatório Macela não foi alterado, sendo obtidas inclusive valores médios maiores, Figura 03. Sendo assim, a elevada turbidez no Reservatório Macela é fortemente influenciada pela elevada densidade de organismos planctônicos, não sendo apenas resultante do material em suspensão.

\subsection{AVALIAÇÃO DAS VARIAÇõES DA QUALIDADE DA ÁGUA USANDO ESTATÍSTICA MULTIVARIADA}

A Análise Hierárquica (AH) e a Análise de Componentes Principais (ACP) foram aplicadas ao conjunto dos dados obtidos em todo período de estudo. A matriz dos dados foi constituída de 8 objetos e 13 variáveis. Os objetos são os sítios de amostragem nos períodos secos (SE) e chuvosos (CH) de 2004, 2005, 2013 e 2014, assim denominados: CH.04, SE.04, CH.05, SE.05, CH.13, SE.13, CH.14, SE.14. As variáveis são os parâmetros medidos: $\mathrm{pH}$, condutividade elétrica, oxigênio dissolvido, sólidos totais dissolvidos, temperatura, transparência, fósforo total, fosfato, nitrato, nitrito, nitrogênio amoniacal, clorofila a e coliformes termotolerantes.

A ACP mostrou que as três primeiras componentes explicaram 77,1\% da variância total dos dados (Tabela 5). A primeira componente principal (CP1) com uma variância total de 38,1\%, está associada principalmente (peso $>0,7$ ) ao $\mathrm{pH}$, condutividade, clorofila a e P04. A CP2 com uma variância total de 22,9 \% apresentou uma correlação forte com o oxigênio dissolvido e sólidos totais dissolvidos, e a PC3 com variância total de 16,1 \% mostrou correlação maior que 0,7 apenas com o N03. No plano formado pelas componentes PC1 e PC2 (Figura 4) pode-se visualizar que as amostras coletadas em 2004-2005 (CH.04, SE.04, CH.05, SE.05), se separaram das amostras coletadas em 2013-2014 (CH.13, SE.13, CH.14, 
SE.14). Isso evidencia que a qualidade da água das amostras coletadas em 2004-2005 são estatisticamente diferente da qualidade da água das amostras coletadas em 2013-2014. As amostras coletadas em 20042005 estão do lado positivo da PC1 e os principais parâmetros que contribuíram para essa separação (peso > 0,7, Tabela 3 ) foram os maiores valores do pH, condutividade, clorofila a e P04. A PC2 separou a amostra coletada no período chuvoso de 2013 (CH.13) das demais. No sentido positivo da PC2 aumentam as concentrações de oxigênio dissolvido e sólidos totais dissolvidos, sendo esses os principais parâmetros (peso > 0,7,4) que diferenciam a qualidade da água da amostra CH.13, em relação as outras amostras.

Tabela 05 - Pesos dos parâmetros da qualidade da água para a composição das componentes principais (em negrito pesos > 0,700, indicativos de forte correlação)

\begin{tabular}{|c|c|c|c|}
\hline Parâmetros & PC1 & PC2 & PC3 \\
\hline $\mathrm{pH}$ & 0.949 & 0.227 & -0.021 \\
\hline Condutividade & 0.870 & 0.223 & 0.069 \\
\hline Oxigênio dissolvido & 0.006 & 0.863 & 0.393 \\
\hline Clorofila-a & 0.751 & -0.091 & -0.141 \\
\hline Sólidos totais dissolvidos & 0.422 & 0.771 & 0.052 \\
\hline Temperatura da água & 0.346 & -0.222 & 0.516 \\
\hline Transparência & 0.649 & -0.663 & -0.163 \\
\hline Fósforo total & -0.475 & 0.407 & -0.625 \\
\hline N-NO3- & -0.080 & -0.362 & 0.880 \\
\hline N-NO2- & 0.617 & 0.675 & 0.067 \\
\hline $\mathrm{N}-\mathrm{NH} 3$ & -0.702 & -0.071 & 0.296 \\
\hline P-P043- & 0.784 & -0.311 & 0.252 \\
\hline Coliformes Termotolerantes & -0.530 & 0.421 & 0.548 \\
\hline Variância total (\%) & 38.0 & 22.9 & 16.1 \\
\hline Variância acumulada (\%) & 38.1 & 61,0 & 77.1 \\
\hline
\end{tabular}

Figura 4 - Localização das amostras no plano formada pelas componentes CP1 e CP2

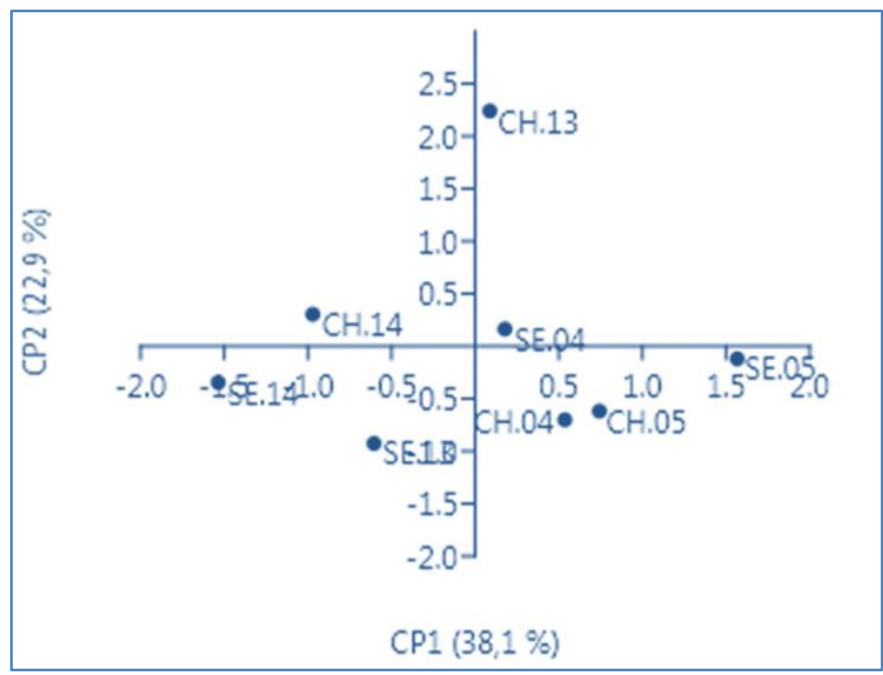

No dendograma resultante da AH ( Figura 5 ), observa-se a formação de três grupos distintos, o grupo A composto pelas amostras coletadas em 2004-2005, o grupo B formado pela amostra CH.13 e no grupo C 
estão incluídas as amostras SE.13, CH.14 e SE.14. Na AH os objetos são agrupados com base nas suas similaridades, ou seja, estão no mesmo grupo as amostras com qualidade da água similares. Portanto a $\mathrm{AH}$ corrobora com os resultados obtidos na ACP, donde se conclui que no período temporal de dez anos (2004 a 2014), ocorreu uma variação pequena, mas significativa na qualidade da água do reservatório Macela, com redução nos valores do pH, condutividade, NO3, PO4 e clorofila a. Apesar disso, o reservatório ainda se mantém hipereutrofizado (2017) e com salinidade da água elevada.

Figura 5 - Dendograma da análise de hierárquica mostrando a similaridade entre as amostras coletas no período 2004 a 2014 ( $\mathrm{CH}=$ chuvoso, $\mathrm{SE}=$ seco)

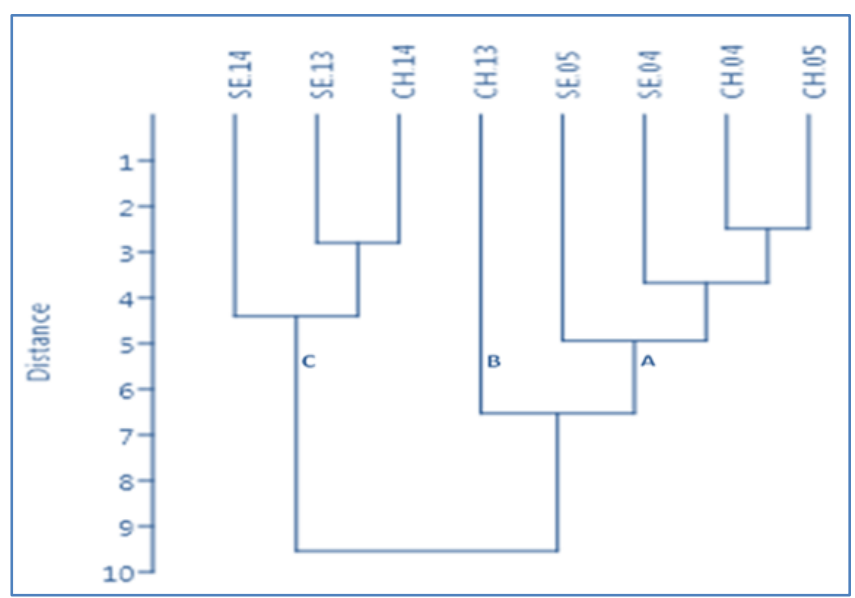

\section{CONCLUSÕES}

A análise estatística multivariada foi utilizada para avaliar a variação da qualidade da água do reservatório Macela, situado na cidade de Itabaina- Sergipe, entre o período de 2004 a 2014. Os parâmetros que apresentaram variações significativas no período temporal 2004 a 2014 foram: pH $(7,3$ - 9,0), condutividade $(977,7$ - $2940 \mu \mathrm{S} \mathrm{cm}-1)$, sólidos totais dissolvidos (547,5 - $1056 \mathrm{mg}$ L-1), oxigênio dissolvido $(3,38$ - 11,23 mg L-1), nitrato $(0,01-2,38 \mathrm{mg} \mathrm{L}-1)$, fosfato $(0,02-1,35 \mathrm{mg}$ L-1) e clorofila a $(22,8-163,2 \mu \mathrm{g} \mathrm{L}-1)$.

Os resultados da Análise de Componentes Principais e Análise Hierárquica indicaram que a qualidade da água das amostras coletadas em 2004 e 2005 são estatisticamente diferentes das amostras coletadas em 2013 e 2014. No período temporal de dez anos (2004 a 2014) ocorreu uma variação pequena, mas significativa na qualidade da água do reservatório, com redução nos valores do $\mathrm{pH}$, condutividade, nitrato, fosfato e clorofila a. Apesar disso, o reservatório ainda se mantém com salinidade elevada, bem como, hipereutrofizado nos cálculos de IET para as metodologias de Carlson, Toledo e Lamparelli, não se notando diferença significativa (One-way ANOVA) entre os valores obtidos pelas três metodologias.

$\mathrm{O}$ açude Macela caracteriza-se como um ambiente enriquecido por nutrientes (N e P) e com elevada produção algal, com o nitrogênio como nutriente limitante da produção algal.

A análise estatística multivariada aplicada ao conjunto dos dados obtidos no período 2004 - 2014, não mostrou uma diferença significativa na qualidade da água do açude para os últimos 10 anos.

\section{AGRADECIMENTOS}

A CAPES e a FAPITEC pela bolsa de mestrado concedida e ao projeto "Monitoramento de Mananciais Superficiais e Reservatórios do Estado de Sergipe" , Convênio ITPS - SEMARH. 


\section{REFERÊNCIAS}

[1] Alves, J. P. H.; Santos, T.T.S.; Oliveira, N.D (2016). Dinâmica do oxigênio dissolvido no estuário do rio do Sal Sergipe. Pesquisa em Políticas Públicas no Estado de Sergipe. Série documentos. São Cristovão - SE, pp. 281- 293.

[2] APHA - American Public Health Association. (2012) Standard Methods for the examination of water and waste water. American Water Works Association, Water Environment Federation. 22. ed. Washington, 2012.

[3] BARBoSA, A. de G; SANTOS, K. M. S.; MICHELAN, D. C. de G. S. (2019). “Avaliação da Sazonalidade da Qualidade da Água do Açude da Macela em Itabaiana/SE”. Scientia Cum Industria, pp. 24-31.

[4] BRASIL (2005). CONAMA - Conselho Nacional do Meio Ambiente. Resolução no 357 de 17 de março de 2005. Brasília - DF; DOU.

[5] BUCCI, M.H.S; OLIVEIRA, L.F.C. de. (2014). “Índices de qualidade da água e de estado trófico na represa Dr. João Penido (Juiz de Fora, MG)”. Revista Ambiente e Água. pp. 130-148.

[6] CARLSON, R.E. (1977). "A trophic state index for lakes”. Limnology and Oceanography, pp. 361-369.

[7] CARPENTER, S.R., STANLEY, E.H., ZANDEN, M.J. (2011). "State of the World's Freshwater Ecosystems: Physical, Chemical, and Biological Changes". Annual Review of Environment and Resources. pp. 75-99.

[8] CARVALHO, D.M. de, COSTA J.E. da. (2010). "A intervenção do estado em infraestrutura e o processo de circulação de hortifrutigranjeiros em Itabaiana/SE”. Scientia Plena. pp. 1-15.

[9] CIGAGNA, C.; BONOTTO, D. M.; STURARO, J. R. (2014). "Batimetria e estudo de parâmetros morfométricos do reservatório da floresta estadual Edmundo Navarro de Andrade. (FEENA) Rio Claro/SP”. Geociências. pp. 720732.

[10] DELGADO, C.; PACHECO, J.; CABRERA, A.; BATLlORI, E.; ORELlANA R; BAUTISTA, F. (2010). "Quality of groundwater for irrigation in tropical karst environment: The case of Yucatán, Mexico". Agricultural Water Management. Pp. 1423 - 1433.

[11] DEPARTAMENTO NACIONAL DE OBRAS CONTRA AS SECAS (DNOCS) - COORDENADORIA ESTADUAL DE SERGIPE (2014). Ficha Técnica Operacional dos Açudes CEST-SE. Aracaju - SE.

[12] EVERITT, B.S.; LANDAU, S.; LEESE, M.; STAHL, D. (2011). Cluster Analysis. Wil, 321 p.

[13] FRAGOSO, C.R.J; TUCCI, C.E.M; COLLISCHONN, W.; MARQUES, D.M.L da M. (2007). "Simulação de Eutrofização em Lagos Rasos: I - Modelo e Precisão Numérica”. RBRH - Revista Brasileira de Recursos Hídricos. pp. 23-35.

[14] GARCIA, C. Z.; GARCIA, D. C. O.; LEITE, M.A. (2007). "Comparação entre dois índices de estado trófico para o reservatório de ilha solteira” in Anais do VII Congresso de Ecologia do Brasil, Caxambu, Set. 2007.

[15] GLIBERT, P.M.; MARANGER, R; SOBOTA, D.J; BOUWMAN, L (2014). “The Haber Bosch-harmful algal bloom (HBHAB)". Environmental Research Letters. 13p.

[16] GOMES, V.R. Impactos ambientais e (in) sustentabilidade no perímetro irrigado da Macela, Itabaiana - Sergipe Brasil. [Dissertação]. São Cristovão (SE): Universidade Federal de Sergipe, 2004. 141 p.

[17] HEISLER, J; GLIBERT, P.M; BURKHOLDER, J.M; ANDERSON, D.M; COCHLAN, W; DENNISON, W.C; DORTCH, Q; GOBLER, C.J; HEIL, C.A; HUMPHRIES, E; LEWITUS, E.A; MAGNIEN, R; MARSHALL, H.G; SELLNER, K; STOCKWELL, D.A; STOECKER, D.K; SUDDLESON, M. (2008). "Eutrophication and harmful algal blooms: A scientific consensus". Harmful pp 3-13.

[18] HOWARTH, R. W.; MARINO, R. (2006). "Nitrogen as the limiting nutrient for eutrophication in coastal marine ecosystems: Evolvingviews over three decades". Limnology Oceanography, pp. 364-376.

[19] KHALIL, B; OUARDA, T.B.M.J. (2009). "Statistical approaches used to assess and redesign surface water-qualitymonitoring networks”. Journal of Environmental Monitoring. pp.1915-1929.

[20] LAMPARELLI, M.C. Grau de trofia em corpos d'água do estado de São Paulo: avaliação dos métodos

de monitoramento [Tese]. Paulo (SP): Universidade de São Paulo, 2004. 235 p.

[21] MINISTÉRIO PÚBLICO FEDERAL - Seção Judiciária de Sergipe, Edição Judicial 29/01/2013. Ação civil pública 0001245-92.2011.4.05.8501.

[22] OLIVEIRA, M. S.; LEITE, J. S.; LIMA, V. A.; CARVALHO, A. C.; OLIVEIRA, T. G. A.; PINHEIRO, J. P. S.; LEITE, L. V.; NUNES, L. T. (2013). "Índice de estado trófico da água do Açude Gavião - CE" in: I CONICBIO/ II CONABIO/ VI SIMCBIO, Recife, 2013.

[23] PANDEY, V.D; PARVEEN, S. (2011). “Alkaline phosphatase activity in cyanobacteria: physiological and ecological significance". Indian Journal of Fundamental and Applied Life Sciences. pp. 295-303.

[24] População Itabaiana. IBGE. 2019. Disponível em:<https://cidades.ibge.gov.br/brasil/se/itabaiana/panorama> . Acesso em: Setembro de 2019. 
[25] SANTOS, C.O. "Questões sócio ambientais nos perímetros irrigados do município de Itabaiana/SE". (2013). Revista ACTA Geográfica. pp.139-152.

[26] SANTOS, J. C. N. dos; ANDRADE, E. M. de; ARAÚJO NETO, J. R. de; MEIRELES, A.C.M.; PALÁCIO, H. A. de Q. (2014). "Land use and trophic state dynamics in a tropical semiarid reservoir". Revista Ciência Agronômica. pp. 35-44.

[27] SANTOS, M. de L. S.; BordAlO, A. O.; PEREIRA, J. A. R.; CHIRA, P. A.; ALVES, I. C. C.; SOdRÉ, S. S. V. (2013). Influência da expansão urbana na qualidade da água em reservatório da região Amazônica (Belém, Pará). Boletim técnico científico do CEPNOR: Tropical Journal of Fisheries and Aquatic Sciences, pp. 15-22.

[28] SCHEFFER, M. “Alternative Attractors of Shallow Lakes”. (2001). The Scientific World. pp. 254-263.

[29] SCHEFFER, M. Ecology of Shallow Lakes. Populations and Community Biology Series. (2004). Springer Science+Business Media, B.V. The Netherlands. 357p.

[30] SCHEFFER, M; van NES, E.H. (2007). "Shallow lakes theory revisited: various alternative regimes driven by climate, nutrients, depth and lake size". Hydrobiologia. pp. 455-466.

[31] SCHINDLER, D.W. "Recent advances in the understanding and management of eutrophication". (2006). Limnology and Oceanography. pp. 356-363.

[32] SENA, I.M.N. Qualidade da água do Reservatório Macela - Itabaiana - Sergipe: variações de curto e longo prazo [Dissertação]. São Cristóvão (SE): Universidade Federal de Sergipe, 2017. 79 p.

[33] SHEELA, A.M, LETHA, J, JOSEPH, S. (2011). "Environmental status of a tropical lake system". Environmental Monitoring and Assessment. pp. 427-449.

[34] SHRESTHA, S, KAZAMA, F. (2007). "Assessment of surface water quality using multivariate statistical techniques: a case study of the Fuji river basin, Japan". Environment Modelling \& Software. pp. 464-475.

[35] SINGH, K.P; MALIK, A; MOHAN, D; SINHA, S. (2004). "Multivariate statistical techniques for the evaluation of spatial and temporal variations in water quality of Gomti River (India): a case study". Water Research. pp. 39803992.

[36] SMITH, V.H; JOYE, S.B; HOWARTH, R.W. (2006). "Eutrophication of freshwater and marine ecosystems". Limnology and Oceanography. pp. 351-355.

[37] SMITH, V.H; SCHINDLER, D.W. (2009). “Eutrophication science: where do we go from here?”. Trends in Ecology and Evolution. pp. 201-207.

[38] STRASKRABA, M; TUNDISI, J. G. (2013). Gerenciamento da qualidade da água de represas. Oficina de textos, International Lake Environment Committe, Instituto Internacional de Ecologia. São Carlos- SP, 300 p.

[39] TOLEDO, Jr. A.P. (1990). Informe preliminar sobre os estudos para obtenção de um índice para avaliação simplificada do estado trófico de reservatórios de regiões quentes tropicais. Relatório técnico. CETESB, São Paulo - SP. 11p.

[40] VON SPERLING, M. (2005). Introdução a qualidade das águas e ao tratamento de esgotos. DESA-UFMG Belo Horizonte - MG, $470 \mathrm{p}$.

[41] WANG, X; CAI, Q; YE, L; QU, X. (2012). "Evaluation of spatial and temporal variation in stream water quality bymultivariate statistical techniques: A case study of the Xiangxi River basin, China". Quaternary International. pp. $137-144$.

[42] ZHANG, X; MEI, X; GULATI, R.D; LIU, Z. (2015). "Effects of N and P enrichment on competition between phytoplankton and benthic algae in shallow lakes: a mesocosm study". Environmental Science and Pollution Research. pp. 4418-4424. 


\section{Capítulo 4}

Análise jurídica e técnica dos procedimentos de outorga do uso da água na bacia hidrográfica do rio Japaratuba/SE.

\section{Luiz Ricardo Santana de Araújo \\ Gregorio Guirado Faccioli \\ Alane Regina Rodrigues dos Santos \\ Iasmine Louise de Almeida Dantas}

Resumo: A escassez da água é um dos principais problemas que o homem terá que enfrentar no século XXI. O grande desafio atual é atender à crescente demanda de água, e, ao mesmo tempo, preservar o recurso que tende à escassez. A outorga de direito de uso de recursos hídricos pode ser um dos meios para solucionar essas questões. A água é essencial para o desenvolvimento das atividades humanas. Seu uso é permitido pela emissão da outorga de direito de uso da água. A definição legal da outorga, pela Lei 9433/97, imprime o comando de desenvolvimento sustentável, pois tem por finalidade assegurar o controle dos usos da água em termos de qualidade e quantidade, referindose implicitamente às presentes e também futuras gerações. Neste contexto, o objetivo central deste trabalho é Analisar técnica e juridicamente a água como bem de uso comum constitucional e a discussão sobre o que é a outorga do direito de uso da água no estado de Sergipe, usando como objeto de estudo a Bacia do Rio Japaratuba.

Palavras-chave: Outorga de direito do uso da água, gestão de recursos hídricos, água, direito ambiental. 


\section{INTRODUÇÃO}

A água é o elemento indispensável ao ser humano, entretanto a aparente abundância no Brasil levou os recursos hídricos a uma situação crítica, facilmente observada nos grandes centros. A expansão agrícola e industrial e o consequente êxodo rural causaram um processo desordenado de urbanização, resultando em uma sobrecarga aos recursos hídricos, principalmente nas áreas com maior densidade populacional, provocando problemas de escassez hídrica em algumas regiões do Brasil, seja pela quantidade insuficiente de água ou pelo comprometimento da sua qualidade.

Episódios de escassez, contaminação e conflitos em seu uso passaram a ser cada vez mais frequentes. A água é, hoje, um fator de inquietação e tem suscitado disputas acaloradas em vários estratos sociais, religiosos e organismos estatais, inclusive na ONU, apesar de cobrir $2 / 3$ da superfície da Terra e com isso aparentar ser infinita para a vida humana, animal e vegetal.

A preocupação com a água é mais direta e mais profunda e decorre da conscientização de que, apesar de cobrir quase a totalidade da Terra, apenas 2,5\% de seu volume é de água doce, sendo que deste percentual $68,9 \%$ são geleiras e neves eternas, $29,9 \%$ são de águas subterrâneas, $0,9 \%$ estão na umidade do solo, nos pântanos e nas geadas e apenas 0,3\% estão em rios e lagos e que, portanto, com o aumento da população mundial, a poluição provocada pelas atividades humanas, o consumo excessivo e o alto grau de desperdício, ela se tornou um bem finito em curto prazo a preocupar toda vida existente na Terra.

O Brasil, que já contava com um aparato legal relacionado ao tema, sancionou a Lei Federal 9.433/97 (BRASIL, 1997) que instituiu a Política Nacional de Recursos Hídricos e adotou diversos instrumentos para equilibrar a oferta e a demanda pelo uso da água entre os diversos tipos de usuários.

No Estado de Sergipe é o Decreto Estadual no 18.456/99 que regulamenta a Outorga de Direito de Uso da Água. Entende-se como uso da água qualquer utilização, serviço ou obra em recurso hídrico, independentemente de haver ou não retirada de água, barramento ou lançamento de efluentes, que altere seu regime ou suas condições qualitativas ou quantitativas, ou ambas simultaneamente.

Todavia, a Constância e a variedade das interferências nos corpos de água e a dinâmica do emprego dos recursos hídricos nos processos produtivos geram a constante necessidade de revisão dos procedimentos, técnicos e jurídicos da legislação relacionada.

Partindo desse contexto, o presente estudo realiza uma análise jurídica e técnica do processo de outorga de direito de uso dos recursos hídricos no Brasil e no Estado de Sergipe, iniciando com considerações acerca da água como bem de domínio público indispensável à vida, porém ressaltando sua finitude e, por isso, a necessidade de protegê-la. Em seguida adentra na discussão sobre a outorga do uso da água, discutida em meio à evolução jurídica brasileira sobre o tema água, abordando os principais marcos legislativos. Apresenta suas modalidades, pontuando que o uso desse recurso constitui ato passível de controle pelo poder de polícia, com exceção dos casos em que o uso não necessita de outorga. Discute-se, ainda, juridicamente a suspensão da outorga como meio administrativo e os principais fatores relacionados, trazendo no seu escopo o que é a outorga do direito de uso da água e a origem da Lei 9433/97. Por fim, encerrando a discussão, apresenta as considerações finais acerca da temática.

\section{REFERENCIAL TEÓRICO}

\section{1 ÁGUA COMO BEM DO DOMÍNIO PÚBLICO E BEM DE USO COMUM}

A água é indiscutivelmente um bem essencial à vida, e a ela diretamente ligado, para Edis Milaré:

[...] ela participa com elevado potencial na composição dos organismos e dos seres vivos em geral, e suas funções biológicas e bioquímicas são essenciais, pelo que se diz simbolicamente que a água é elemento constitutivo da vida. Dentro do ecossistema planetário, seu papel junto aos biomas é múltiplo, seja como integrante da cadeia alimentar e de processos biológicos, seja como condicionantes dos diferentes habitats .(MILARÉ, 2000, p. 126)

Entretanto, para alguns estudiosos faz-se necessária a distinção entre os termos "água" e "recurso hídrico", no estudo de matérias relacionadas à água. Para o jurista Pompeu (2006, p.71): 
Água é o elemento natural, descomprometido com qualquer uso ou utilização. É o gênero. Recurso hídrico é a água como bem econômico, passível de utilização para tal fim. Por essa razão, temos um Código de Águas e não um Código de Recursos Hídricos. Adotando o termo no sentido genérico, o Código disciplina o elemento líquido, com aproveitamento econômico ou não, como são os casos de uso para as primeiras necessidades da vida, da obrigatoriedade dos prédios inferiores de receberem as águas que correm naturalmente dos superiores, das águas pluviais etc.

De fato, os diplomas legais pátrios não diferem as expressões "água" e "recurso hídrico", e tampouco atribuem expressamente a conotação econômica para recurso hídrico.

A Constituição Federal de 1988, determinou que as águas são bens do domínio da União, dos Estados e, por analogia do Distrito Federal. No mesmo diploma legal, no capítulo destinado especialmente ao Meio Ambiente, o caput do art. 225 dispõe que: "Todos têm direito ao meio ambiente ecologicamente equilibrado, bem de uso comum do povo e essencial à sadia qualidade de vida, impondo-se ao Poder Público e à coletividade o dever de defendê-lo e preservá-lo para as presentes e futuras gerações."

A água é um dos elementos que compõe o meio ambiente. De acordo com o inciso V, art.3ㄹ da Lei 6.938, de 31 de agosto de 1981, que dispõe sobre a Política Nacional de Meio Ambiente, a água constitui um dos recursos ambientais.

A Lei n 9.433/97, em seu art.l0, prescreve que "a água é um bem de domínio público", e este dispositivo está em perfeita consonância com a natureza jurídica da água, a qual além de bem do domínio público, é também um bem ambiental.

Para Granziera (2001, p.26)

"não há como negar a prevalência do interesse público sobre o privado no que se refere aos recursos hídricos, inclusive pelo fato de serem eles considerados recursos ambientais, e a Lei $\mathrm{n}^{\circ}$ 9.433/97 tê-los declarado como bens de domínio público".

No entanto, para alguns autores como Celso Pacheco Fiorillo, Ana Claudia Bento Graf e Luciana Cordeiro De Souza, a Constituição de 1988 consagrou o bem difuso no caput do art. 225, portanto, ao lado dos bens públicos e privados, há uma terceira categoria de bem, o difuso.

Esta corrente doutrinária entende que a água como bem ambiental, de uso comum do povo, deve ser classificada como um bem difuso. Portanto, não há que falar na água como bem do domínio da União ou dos Estados, pois domínio público significa propriedade e o bem ambiental ou denominado difuso não possui propriedade, mas uma titularidade transindividual, devendo ser acessível a todos.

Neste contexto, Fiorillo (2000, p.104), ao analisar o inc.I, art.10, da Lei nº 9.433/97, invoca,

a "inconstitucionalidade" deste dispositivo, No inc.I desse artigo, preceituou-se que a água é um bem de domínio público. Tal assertiva padece de inconstitucionalidade, porquanto, conforme foi demonstrado, a água é um bem tipicamente ambiental, sendo, portanto, de uso comum do povo, e , em conformidade com a Lei 8.078/90(art.81, parágrafo único, I), bem difuso. Dessa forma, o art.10, I, encontra-se em total desarmonia com o Texto Constitucional não encontrando qualquer suporte de validade.

Em que pese o respeito pela peculiar visão jurídica deste assunto, trazemos com ênfase entendimentos contrários aos apresentados pelos nobres juristas. Para Machado (2003, p. 423), "a dominialidade pública da água, afirmada na Lei $n^{\circ}$ 9.433/97, não transforma o Poder Público federal e estadual em proprietário da água, mas torna-o gestor desse bem, no interesse de todos."

Domínio público: "E a propriedade das coisas das pessoas de Direito Público, isto é, da União, dos Estados e Municípios". NAÚFEL, Novo Dicionário Jurídico Brasileiro, 493. E continua o jurista (2003, p.423-424),

O legislador brasileiro agiu bem ao considerar todas as águas "de domínio público" no sentido de "bem de uso comum do povo". O Prof. Michel Prieur critica o sistema legal francês, dizendo que "infelizmente, por ter faltado a ousadia de nacionalizar a água, como patrimônio coletivo, os múltiplos regimes jurídicos subsistem em sua complexidade e em sua imbricação, ainda que tenha sido elaborada a Lei das Águas de 3 de janeiro de 1992. 
A água atende inúmeras necessidades vitais; ora como produto para consumo direto, ora como matériaprima, ora como ecossistema. Segundo Erhard-Cassegrain e Margat (1983) apud Leal, (1998) podem-se destacar quatro funções principais desempenhadas pela água:

a) biológica: água para as necessidades básicas humanas e animais;

b) ecossistêmica: meio ambiente para seres aquáticos;

c) técnica: usos em que a água desempenha papel de matéria-prima na indústria e na agricultura ou em usos residenciais não-básicos; e

d) simbólica: usos associados a valores sociais e culturais.

Todavia, pode-se dizer que as duas primeiras funções são as mais essenciais e que e se relacionam com necessidades vitais básicas. A terceira relaciona-se com usos que excedem as necessidades básicas e que são decorrência de práticas econômicas. A última função é decorrente de considerações técnicoeconômicas, culturais e políticas e, portanto, é uma função, a princípio, mais flexível e passível de negociações e modificações, a função simbólica é subjetiva e depende de fatores culturais (LEAL, 1998).

\subsection{OUTORGA DE USO DA ÁGUA}

Por se tratar de bem de uso comum do povo a água recebeu atenção especial do legislador quanto à sua forma de concessão a terceiros. Nesse sentido, a Lei 9.433/97 apresenta a outorga como instrumento jurídico apto a conceder, levando em conta a necessidade de efetivar o direito de acesso à água, o direito de uso a particulares, estabelecendo critérios objetivos a serem seguidos pela administração, sem deixar de lado todos os princípios norteadores daquela, mormente a conveniência e a oportunidade.

Para Silveira, Robiana e Giotto (1998), a outorga de uso é o principal instrumento para a administração da oferta de água, que se constitui na base de processo de gerenciamento de recursos hídricos. A tarifação pelo uso da água também se constitui em um instrumento de gestão, por incentivar a adoção de medidas que induzam ao decréscimo do consumo e torne-se, também, mecanismos de financiamento de serviços e obras necessárias à melhoria das condições qualiquantitativas dos recursos hídricos.

Se uma pessoa física ou jurídica quiser fazer uso das águas de um rio, lago ou mesmo águas subterrâneas, terá que solicitar uma autorização (outorga) ao poder público. 0 uso mencionado refere-se, por exemplo, à captação de água para processo industrial ou irrigação, lançamento de efluentes industriais ou urbanos, ou ainda à construção de obras hidráulicas como barragens, canalizações de rio entre outros (MMA/ANA, 2000a).

\subsection{DAS MODALIDADES DE OUTORGA}

A outorga pode ocorrer entre administrações, bem como entre o particular e o ente administrativo. A respeito da outorga que ocorre entre aqueles entes o eminente Desembargador Welligton Pacheco Barros aduz:

A Administração Pública detentora da competência para administrar o uso da água pode entender de outorgar essa competência à outra administração. Neste caso, o direito de outorga será instrumentalizado por acordos, ajustes ou convênios, sempre de natureza onerosa. Embora estes acordos, ajustes ou convênios tenham a estrutura de verdadeiros contratos já que criam direitos e obrigações entre as administrações envolvidas, eles dispensam a prévia licitação porque são contratos entre administrações e não contratos administrativos cujos participantes são, de um lado, uma Administração Pública, e, de outro, particulares, consoante o disposto no art. 2o, parágrafo único, da Lei no 8.666/93, que institui normas para as licitações e contratos administrativos (BARROS, 2005, p. 87).

Não se tratando de administrações, e sim entre particulares, há uma série de usos da água que necessita de autorização do poder público para que se possa executá-las em consonância com o ordenamento jurídico brasileiro. A Lei no 9.433/97, no seu art. 12, estabelece quais as modalidades de direito de uso de água que necessitam de outorga. Na derivação ou captação de parcela de água existente em um corpo de água para consumo final, inclusive abastecimento público, ou insumo de processo produtivo. 
Derivação significa desvio e captação significa aproveitamento. Corpo de água é qualquer rio, córrego, riacho, lago, lagoa ou brejo. Portanto, o desvio ou aproveitamento de água existe em um rio, córrego, riacho, lago, lagoa ou brejo que se destine ao consumo da população ou mesmo que se destine como elemento no processo de produção de bens exige outorga de direito de uso por parte da Administração Pública competente (BARROS, 2005).

A Lei no 9.433/97 também estabelece que a sua inexistência gera abusividade passível de controle pelo poder de polícia da administração ou até mesmo por ação civil pública ajuizada pelo Ministério Público ou de ação popular por qualquer do povo.

Outra modalidade de outorga é a extração, que pode ser utilizada com o objetivo de obter água para consumo final ou mesmo para uso no processo produtivo. Essa modalidade tem como foco a captação de águas em Aquíferos subterrâneos, formações geológicas capazes de armazenar, no subsolo, e fornecer quantidades significativas de água.

O uso da água sem a outorga administrativa constitui prática abusiva a ser controlada e impedida pelo poder público, pelo Ministério Público ou por qualquer do povo em defesa do bem público.

\subsection{GESTÃO DE RECURSOS HÍDRICOS NO ESTADO DE SERGIPE}

No Estado de Sergipe, a Gestão de Recursos Hídricos, no que tange à questão legislativa, acompanha a evolução das normas de caráter nacional, sejam de proteção ou de sistematização. Prova disso é que a Constituição Estadual destina uma seção aos Recursos Hídricos, com referência explicita à prioridade da utilização das reservas de águas doce para o abastecimento às populações, bem como a obrigação das autoridades e órgãos estaduais e municipais de adotarem medidas para a proteção das águas contra ações que venham a comprometer o seu uso, tanto pela atual quanto pela futura geração ( Artigo 239, III), entre outros como:

I - A utilização racional e proteção contra poluição das águas superficiais e subterrâneas;

II - O aproveitamento múltiplo e compatibilização dos usos dos recursos hídricos efetivos e potenciais, na forma da lei, reduzindo seus efeitos adversos;

IV - A defesa contra eventos críticos que oferecem riscos à saúde e segurança pública e prejuízos econômicos ou sociais;

V - A adoção da bacia hidrográfica e consideração do ciclo hidrológico em todas as fases como base de planejamento e execução de planos, programas e projetos, e da gestão de recursos hídricos;

VI - Registro, acompanhamento e fiscalização das concessões de direitos de pesquisa e exploração de recursos hídricos no território do Estado;

VII - Descentralização, participação e integração em relação aos demais recursos naturais.

Em relação às águas doces, a Constituição Sergipana prevê a obrigação da instituição de um programa permanente para conservação e proteção das águas. A Lei 3870/97, que estabelece a Política Estadual de Recursos Hídricos, segue a mesma redação da Lei Federal 9433/97, criando o Fundo Estadual de Recursos Hídricos e o Sistema Estadual de Gerenciamento de Recursos Hídricos.

O Decreto 18.456/99 regulamenta a outorga e direito de uso de recursos hídricos, de domínio do Estado, de que trata a lei 3.870/97. Pelo artigo $5^{\circ}$ do aludido decreto, o lançamento, em corpo hídrico, de esgotos e demais resíduos líquidos é um uso da água sujeito a outorga, uma vez que utilizará vazão disponível no rio para seu afastamento, diluição ou depuração e ainda estão sujeitos a outorgas:

I - A implantação de qualquer empreendimento que possa demandar a utilização de recursos hídricos e que implique alteração do regime, da quantidade ou da qualidade da água existente em um corpo hídrico superficial ou subterrâneo;

II - A execução de obras ou serviços que configurem interferência e impliquem alteração do regime, da quantidade ou da qualidade da água existente em um corpo hídrico superficial ou subterrâneo;

III - A derivação ou captação de parcela de água existente em um corpo hídrico, para consumo final, inclusive abastecimento público ou insumo de processo produtivo; 
V - O uso para fins de aproveitamento de potenciais hidrelétricos.

No seu artigo 11, define que a outorga de lançamento de afluentes deve ser dada pela quantidade necessária para a diluição da carga poluidora, em função da concentração limite da cada indicador de poluição.

O Decreto no 18.099, de 26 de Maio de 1999, dispõe sobre o Conselho Estadual de Recursos Hídricos CONERH/SE, que dentre inúmeras finalidades deve estabelecer critérios gerais para a outorga de direitos de uso de recursos hídricos (Art. 2oㅡ, VII).

Ainda nesta perspectiva, é importante ressaltar que o Decreto n⿳a 20778 de 21 de Junho de 2002, Institui o Comitê da Bacia Hidrográfica do Rio Sergipe, com a finalidade de promover, no âmbito da gestão de recursos hídricos, a viabilização técnica e econômico financeira de programa de investimento e consolidação de política de estruturação urbana e regional, visando ao desenvolvimento sustentado da Bacia.

Em que pese a vasta disposição legislativa, a falta de aplicação do Plano de Bacia e do Plano Estadual de Recursos Hídricos representam um dos maiores problemas na efetivação da legislação. Os referidos planos ainda encontram pendências em suas etapas que impedem sua vigência, impedindo uma melhor efetivação da legislação.

\section{METODOLOGIA}

A análise jurídica teve como objetivo esclarecer o que é outorga do direito do uso da água. Verificar, através de uma análise histórica, qual a origem do instituto trazido pela Lei 9.433/97 e, partindo de um estudo dedutivo constatar a "eficácia" da mesma no estado de Sergipe. Só após a consciência do conceito de outorga e da possível, constatação, da eficácia na bacia do rio Japaratuba é que pode-se apresentar algum juízo de valor acerca da situação.

0 estudo aqui perpetrado, também, perpassa pela aplicação dos princípios do direito ambiental no processo de outorga, de forma a tentar explicar que embora o processo de outorga possa garantir o direito ao uso da água a um sujeito determinado, a garantia do direito não exime a responsabilidade do poder público em caso de dano ao bem outorgado.

Dessa forma, torna-se extremamente relevante uma nova perspectiva técnica e jurídica que procure conciliar as demandas e as responsabilidades. Enfatizar a obrigação de procurar soluções adequadas às consequências e aos efeitos negativos de ações e julgamentos equivocados, realizados sobre aspectos econômicos, sociais, e políticos. Impor a obrigação de proteger as condições de existência do futuro, as quais são expostas cotidianamente a estados de insegurança e imprevisão sobre os graus de sua possibilidade, demandando uma intervenção na regulação jurídica, com vistas a solucionar a crise ambiental.

A análise teve sempre em vista o conceito básico de gestão dos recursos hídricos, que visa à correta utilização do bem, de forma a garantir-lhe a devida proteção e a promoção do uso racional.

O estado de Sergipe está dividido em oito bacias hidrográficas, as bacias do Rio São Francisco, do Rio Vaza Barris, do Rio Real, do Rio Japaratuba, do Rio Sergipe, do Rio Piauí e as Bacias Costeiras do Sapucaia e Caueira/Abaís.

Para a análise técnica da outorga de água, o recorte espacial utilizado foi a bacia hidrográfica do rio Japaratuba (Figura 1), que é a terceira menor com uma área de $1.674,24 \mathrm{Km} 2$, representando cerca de $7,50 \%$ de todo o território do Estado. Está situada entre as latitudes $10^{\circ} 14^{\prime \prime} 00^{\prime \prime}$ e 104" $00^{\prime \prime}$ S (SERGIPE b, 2013), e as longitudes $37^{\circ} 18^{\prime \prime} 00^{\prime \prime}$ e $36^{\circ} 14^{\text {" }} 00^{\prime \prime}$ W, abrangendo 18 de seus municípios com uma população total de 119.689 habitantes, sendo 40.667 de área rural e 79.012 vivendo em área urbana (SEMARH/SRH,2012).

O rio Japaratuba tem uma extensão de $124 \mathrm{Km}$ e sua bacia é composta por quatro Unidades de Planejamento que auxiliam na gestão dos $124 \mathrm{Km}$ do Rio Japaratuba: UP 04 - Alto Japaratuba, UP 05 Japaratuba Mirim, UP 06 - Siriri e UP 07 - Baixo Japaratuba, possuindo uma demanda hídrica na ordem de $30.496 .960 \mathrm{~m} 3 /$ ano (SEMARH/SE, 2010), mas o quadro atual do balanço hídrico demonstra a limitação quanto ao aumento das demandas, pois é desfavorável na maioria das UPs, sendo classificadas em estado "deficitário" as UPS 05, 06, e 07 é classificada em estado "crítico" a UP 04, classificação ligada ao fato desta UP receber transposições da DESO - Companhia de Saneamento de Sergipe, através da adutora sertaneja. $\mathrm{Na}$ outra extremidade, com um déficit mais elevado $(273 \mathrm{l} / \mathrm{s})$ encontra-se a UP 07 , localizada na região 
onde a maior parte da demanda de água e utilizada nos processos industriais da exploração do petróleo e gás (SEMARH/SE, 2010).

Figura 1 - Localização da bacia Hidrográfica do Rio Japaratuba

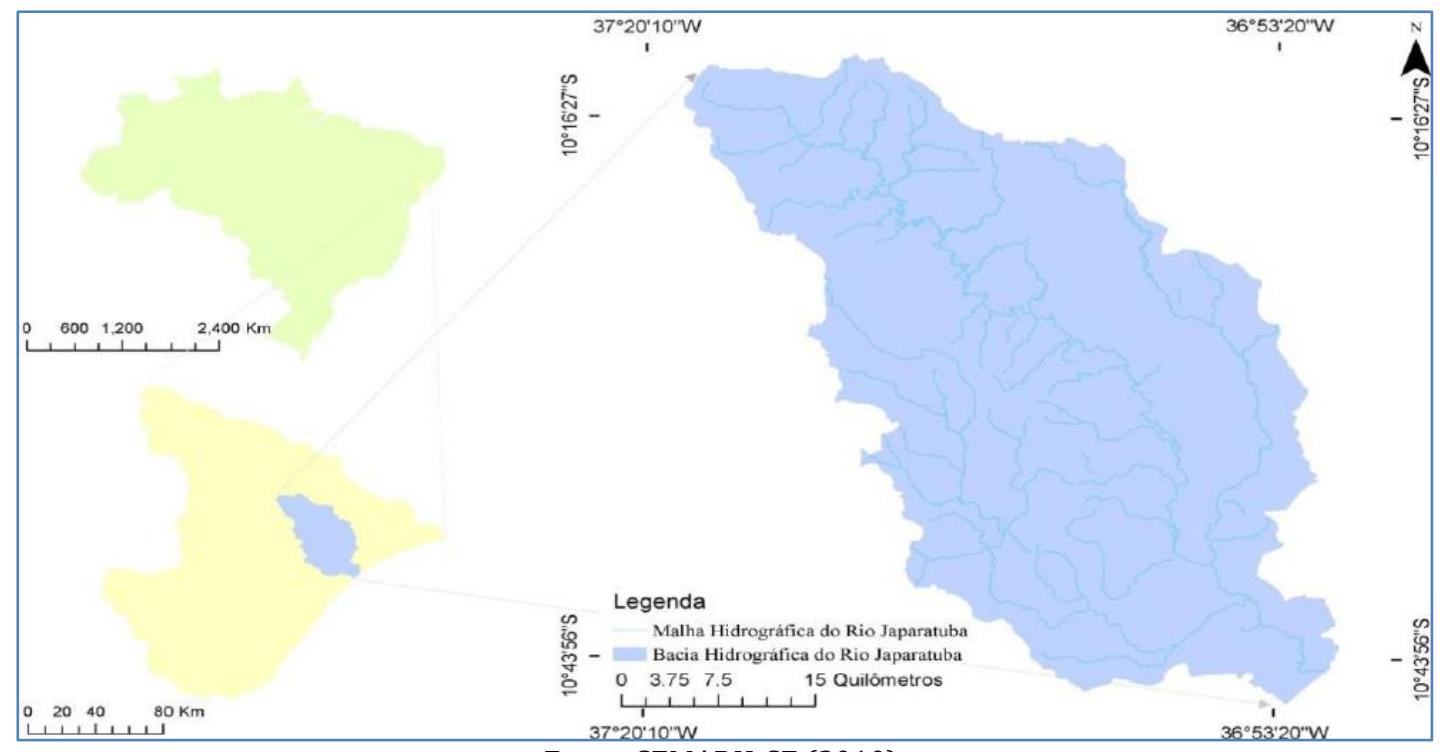

Fonte: SEMARH-SE (2010)

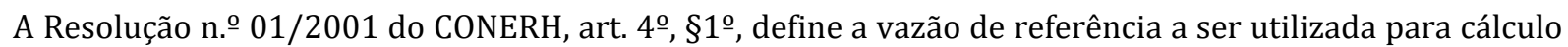
das disponibilidades hídricas superficiais (captação a fio d"água) nos locais de interesse das bacias do estado de Sergipe é a Q90 (vazão com 90\% de garantia de ocorrência). Ainda segundo a Resolução n.o 01/2001 do CONERH, art. 4으, §2o as outorgas de direito de uso de água para as derivações em um corpo hídrico superficial, deve ser prevista uma vazão ambiental para jusante equivalente a 10\% da Q90.

Para verificar a quantidade de água outorgável da referida bacia, o recorte espacial utilizado foi o Rio Japaratuba. A curva de permanência utilizada foi a determinada por Cruz (2010). Assim, a Q90 é igual a $0,34 \mathrm{~m} 3 / \mathrm{s}$ para registros de vazões diárias.

Por fim, foram solicitadas junto à SEMARH todas as outorgas já fornecidas para esta bacia. Com as informações oficiais da SEMARH as outorgas concedidas foram categorizadas e foi verificado se as outorgas de direito de uso de água para as derivações em um corpo hídrico superficial garantiram pelo menos uma vazão ambiental para jusante equivalente a $10 \%$ da Q90.

\section{RESULTADOS E DISCUSSÃO}

\subsection{ASPECTOS LEGAIS DA OUTORGA DE DIREITO DE USO DE RECURSOS HÍDRICOS}

A primeira lei a tratar sobre a água no Brasil, o Código de Águas, de 1934, que embora dispusesse sobre a possibilidade de outorga de uso pelo poder público, em verdade, tratava esse bem com ênfase de domínio privado. No entanto, assimilando a evolução de transformação da água em bem essencial à vida na Terra, a Constituição Federal do Brasil de 1988 introduziu esse importante avanço e a considerou como bem do domínio público (art. 20, inciso III), também chamado de bem de uso comum do povo, situação reafirmada em termos de competência federativa pelos Estados de existência de condominialidade com a União, como sustentada pela Constituição do Estado de Sergipe (art. 239, inciso I, II, III, IV, V, VI e VII).

A Lei no 9.433/97 não utilizou os termos "concessão" e autorização" para outorga de direito de uso da água, como foi disposto pelo Código de Águas. A referida lei apenas menciona o "regime de outorgas" mantendo, em princípio, a sistemática do Código de Águas.

Segundo a Nota Técnica da Agencia Nacional de Aguas- ANA, n 102, de 17 de março de 2005: A outorga, como instrumento de gestão de recursos hídricos do tipo comando e controle, somente é eficaz no alcance de seus objetivos quando existe um regime de outorga, de fato, implantado. Esse regime pode ser 
caracterizado quando a maior parte dos usos dos recursos hídricos é conhecida e legalizada, quando existem regras claras de uso e quando existe uma estrutura institucional de controle e fiscalização de usos de recursos hídricos.

Dessa forma, além da simples emissão, administração e controle de outorgas, é necessária a implementação de regimes de outorgas, para a eficácia do instrumento.

Contudo, a Lei no 9.984, de 17 de julho de 2000, que criou a própria Agência Nacional de Águas, em seu art. 4ํㅡㄹ inciso IV, determinou que a outorga será concedida por meio de autorização, revogando assim a utilização dos institutos da concessão e da autorização da outorga nos termos definidos pelo Código de Águas. Portanto, a natureza jurídica da outorga de direito de uso da água é de ato administrativo de autorização.

Pompeu (1992, p.173) define a autorização administrativa como:

ato administrativo discricionário, pelo qual se faculta a prática de ato jurídico ou de atividade material, objetivando atender diretamente ao interesse público ou privado, respectivamente, de entidade estatal ou de particular, que sem tal outorga seria proibida.

A discricionariedade da outorga é norteada pelas prioridades de seu uso definidos no Plano de Bacia, aprovado pelo Comitê de Bacia, após a participação dos usuários e da sociedade na tomada de decisões. A precariedade também é uma característica do ato de outorga.

A precariedade representa a possibilidade de o órgão outorgante suspender ou revogar a outorga a qualquer momento, mediante motivação, mas sem direito a indenização ao outorgado, por duas razões: pela vigência da outorga estar limitada ao interesse público, mesmo que concedida com fundamentos em interesse particular, e pela inconstância da disponibilidade hídrica não possibilitar o direito adquirido da outorga aos usuários outorgados. Desse modo,

Delinear o regime jurídico de um instituto, bem como definir-lhe a natureza jurídica é situá-lo no sistema jurídico a que pertence. Ao ordenamento jurídico de cada país cabe definir a natureza jurídica das águas nele existentes. No Brasil a Constituição Federal de 1988, praticamente publicizou todas as águas, ao reparti-las entre a União e os Estados, sem deixar espaço para a inclusão das águas municipais, das particulares e das comuns. Pelo fato de pertencerem à União e aos Estados, pessoas jurídicas de direito público, inserem na categoria de bens públicos, podendo ser principalmente, de uso comum e dominicais.(POMPEU, 1992, p. 79)

Por se tratar de bens públicos, a classificação das águas deve estar de acordo com o Código Civil, que "[...] oferece as coordenadas para a classificação fundamental que informa todo nosso sistema jurídico." (POMPEU, 1993). Sendo assim, podem ser, predominantemente, de uso comum ou dominicais, já que a categoria uso especial não se lhes aplica com facilidade.

\subsection{ANÁLISE TÉCNICA DAS OUTORGAS CONCEDIDAS NA BACIA HIDROGRÁFICA DO RIO JAPARATUBA}

A figura 2 apresenta a hidrografia da Bacia Hidrográfica do Rio Japaratuba. Além do Rio Japaratuba que representa o principal corpo hídrico da bacia, a mesma possui os Rios Siriri, Caripau, Cagamba, Aldeia, Cancelo, Mariçoba e Prata e os principais Riachos Siriri Morto, Riachão, Cajueiro e Cabral. 
Figura 2 - Hidrografia da Bacia Hidrográfica do Rio Japaratuba.

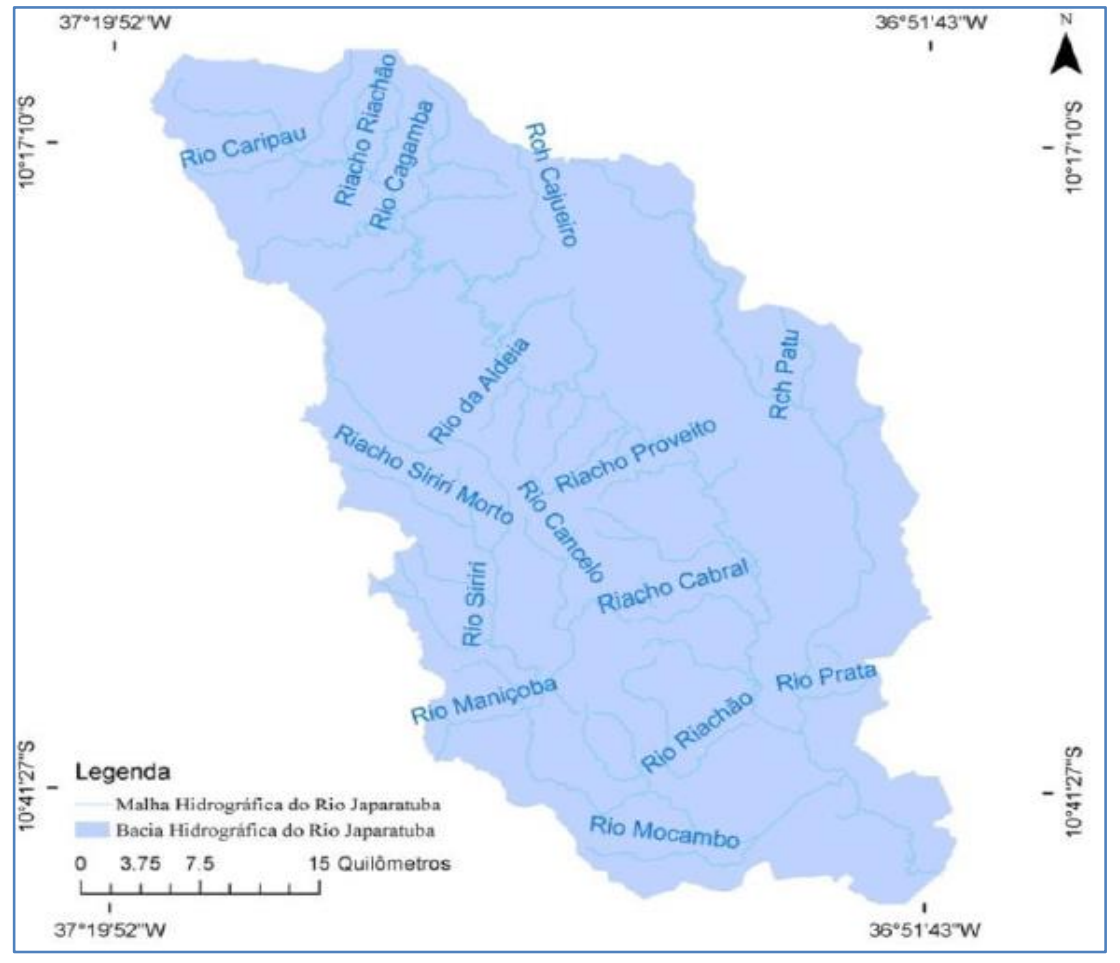

Fonte: SEMARH-SE (2010)

Os principais usos do solo na Bacia Hidrográfica do Rio Japaratuba, são: Pastagens (59,11\%), localizadas no Alto Japaratuba, Cultivos Agrícolas e Solo Exposto (23,47\%) localizados no Alto Japaratuba, Floresta Estacional $(7,71 \%)$ localizada no Alto Japaratuba, Mata Ciliar $(2,62 \%)$ localizada no Alto Japaratuba, Floresta Ombrófila (3,16\%) localizada no Baixo Japaratuba e Manguezal $(1,16 \%)$ localizado no Alto Japaratuba. O restante do solo da Bacia (2,77\%) representa Caatinga Arbustiva Arbórea, Povoado/Distrito, Sede Municipal, Área Degradada, Área Embrejada, Dunas e Areial, Vegetação de Restinga, Viveiro/Salina, Área Industrial e Corpos d'água.

A Figura 3 apresenta as outorgas subterrâneas concedidas pela SEMARH-SE na Bacia Hidrográfica do Rio Japaratuba de 2002 a 2012. Foram concedidas 70 outorgas subterrâneas com vazão total de 0,8798 m3/s. Os principais usuários destas outorgas são: Petrobrás, DESO, Sabe Alimentos e Vale. Das 70 outorgas concedidas 33 são de exclusividade da Petrobrás com vazão total de $0,4158 \mathrm{~m} 3 / \mathrm{s}$ o que corresponde a $47 \%$ das vazões outorgadas na Bacia. Para a Vale foram concedidas 4 outorgas com vazão total de 0,1347 m3/s correspondendo a $15,31 \%$ das vazões outorgadas na Bacia. Para a DESO foram concedidas 9 outorgas com vazão total de $0,1531 \mathrm{~m} 3 / \mathrm{s}$ correspondendo a $17,40 \%$ das vazões outorgadas na Bacia. 
Figura 3 - Outorgas subterrâneas na Hidrografia da Bacia Hidrográfica do Rio Japaratuba concedidas pela SEMARH-SE.

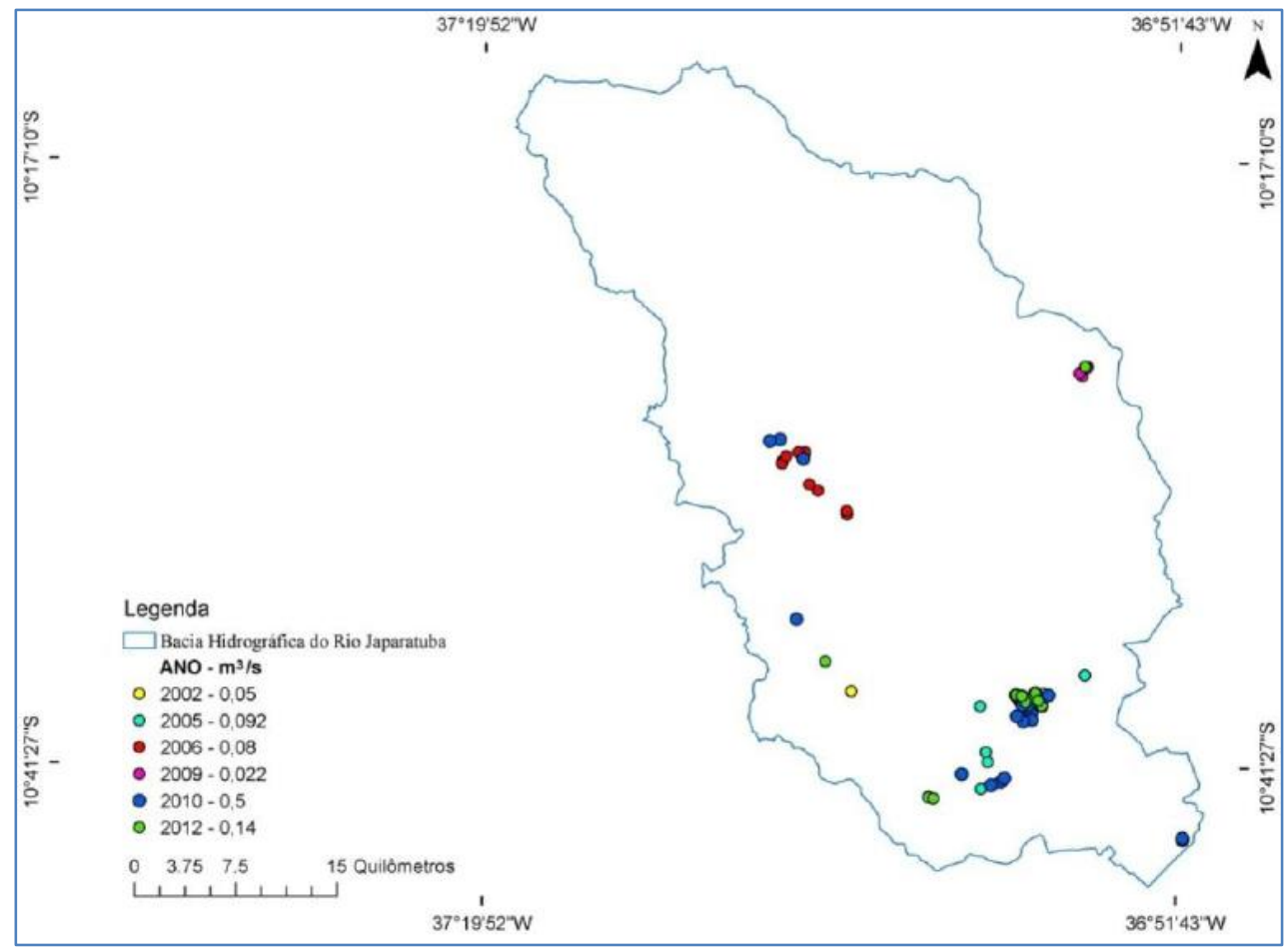

Fonte: SEMARH-SE (2010)

A Figura 4 apresenta as outorgas superficiais concedidas pela SEMARH-SE na Bacia Hidrográfica do Rio Japaratuba no ano de 2012. Foram concedidas 20 outorgas superficiais com vazão total de 1,15 m3/s. 0s principais usuários destas outorgas são: particulares, Agro Industrial Campo Lindo LTDA, Agro Industrial Capela LTDA e a Usina Termo Elétrica Iolando Leite. Das 20 outorgas concedidas 4 são de exclusividade da Agro Industrial Campo Lindo LTDA com vazão total de 0,5892 m3/s o que corresponde a 51,24\% das vazões outorgadas na Bacia. Para a Usina Termo Elétrica Iolando Leite foram concedidas 2 outorgas com vazão total de $0,2222 \mathrm{~m} 3 / \mathrm{s}$ correspondendo a 19,32\% das vazões outorgadas na Bacia. Para a DESO foi concedida 1 outorga com vazão total de $0,028 \mathrm{~m} 3 / \mathrm{s}$ correspondendo a 2,40\% das vazões outorgadas na Bacia.

Observa-se ainda pela Figura 4 que o total das vazões outorgadas quando comparadas a $20 \%$ da Q90 determinada por Cruz (2010) correspondem a 338,40\% deste valor. Na Bahia a outorga de água superficial é concedida considerando que cada usuário pode outorgar individualmente até $20 \%$ da Q90. Se este critério técnico fosse adotado na Bacia Hidrográfica do Rio Japaratuba seis usuários não teriam suas outorgas concedidas pois ultrapassam este valor. 
Figura 4 - Outorgas superficiais na Hidrografia da Bacia Hidrográfica do Rio Japaratuba concedidas pela SEMARH-SE.

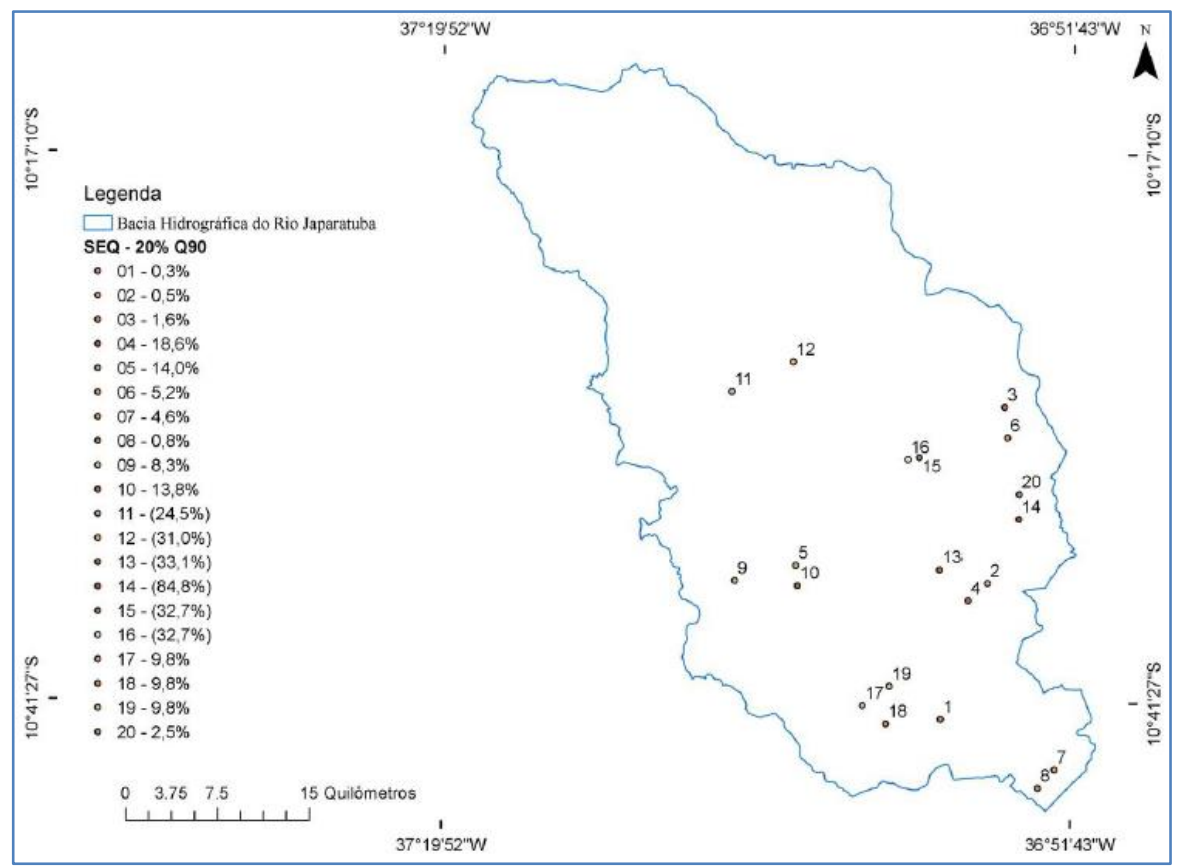

Fonte: SEMARH-SE (2010)

Em Sergipe o critério técnico para garantir as outorgas de direito de uso de água para as derivações em um corpo hídrico superficial, prevê uma vazão ambiental para jusante equivalente a 10\% da Q90. Observase que em apenas um ponto de outorga concedida a Agro Industrial Campo Lindo LTDA representa uma vazão de 0,2882 m3/s, estando muito próxima de $90 \%$ da Q90 que é de 0,306 m3/s, vazão esta máxima outorgável. Estes valores indicam que a Bacia Hidrográfica do Rio Japaratuba encontra-se com graves problemas de disponibilidade hídrica e novos usuários poderão enfrentar conflitos pelo uso da água.

Apesar da sua baixa disponibilidade hídrica, os usos múltiplos da água superficial apresentam-se intensos na bacia, destacando-se a utilização da água nas atividades de exploração mineral, principalmente de petróleo/gás e potássio, abastecimento humano e irrigação (PANTALEÃO, 2006, citado por CRUZ (2010)).

\section{CONCLUSÃO}

A definição legal da Outorga pela lei no 9.433/97, imprime o comando de desenvolvimento sustentável, pois tem por finalidade assegurar o controle dos usos da água, em termos de qualidade e de quantidade, e possibilitar o acesso de "todos" à água, referindo se implicitamente às presentes e também futuras gerações.

Neste sentido, para analisar a água como bem de uso comum constitucional e a discussão sobre o que é a outorga do direito de uso da água no Estado de Sergipe, recorreu-se à sua natureza jurídica, como facilitadora das decisões a serem tomadas, com o escopo de se atingir as previsões constitucionalmente estabelecidas e reiteradas no texto legislativo ordinário.

Nesta toada, chegou-se ao melhor entendimento acerca da natureza jurídica mais adequada a ser empregada, sem dúvida, à compreensão de que a outorga do direito de uso da água é um contrato administrativo formal, bilateral, oneroso e que deve ser fixado por prazo determinado. 0 que significa dizer que, diferentemente do Código das Águas, a Lei das Águas deixou de considerar a outorga como ato administrativo autorizativo para inseri-lo como contrato administrativo sui generis, admitindo, dessa forma, a possibilidade de revogação do ato, que não atenda aos anseios do constituinte, ou seja, que não garanta a proteção e o uso escorreito do bem em análise.

Portanto, a Lei $n^{\circ}$ 9.433/97 dotou o país de instrumentos eficazes na proteção do bem "água", assim como a viabilidade de acesso a esse bem. 0 que se precisa entender agora é que o desperdício leva a finitude, e que o principio basilar é a preservação. Entretanto, mesmo existindo leis que administrem esse recurso 
ambiental, necessário se faz a modificação da postura social, com mudanças de habito e educação ambiental, para que se possibilite às gerações vindouras o mesmo recurso de que estamos usufruindo agora.

Quando foi analisado o critério técnico adotado no Estado de Sergipe para concessão de outorgas superficiais e sua aplicação na Bacia Hidrográfica do Rio Japaratuba conclui-se que novos usuários poderão enfrentar conflitos pelo uso da água.

\section{REFERÊNCIAS}

[1] BARROS, W. P. A Água na Visão do Direito. Porto Alegre: Tribunal de Justiça do Rio Grande do Sul, 2005;

[2] BRASIL. Constituição da República Federativa do Brasil, Lei no 9.433, de 8 de janeiro de 1997. Institui a Política Nacional de Recursos Hídricos. Disponível em: < http://www.planalto.gov.br/ccivil_03/LEIS/L9433.htm >. Acesso em: 13 de ago. de 2013.

[3] CRUZ, Marcus Aurélio Soares. Análise do comportamento hidrológico do rio Japaratuba em Sergipe. III Encontro de Recursos Hídricos em Sergipe - 24 a 26 de março de 2010, Aracaju/SE. Disponível em: <http://www.cpatc.embrapa.br/publicacoes_2010/anais3_enrehse/Resumos_expandidos/IIIENREHSE_\%20An \%C3\%A1lise\%20do\%20comportamento\%20hidrol\%C3\%B3gico\%20do\%20rio\%20Japaratuba\%20em\%20Sergi pe.pdf>. Acessado em 22 de julho de 2014;

[4] FIORILLO, Celso Pacheco. Curso de Direito Ambiental Brasileiro, 1ª. ed. São Paulo: Saraiva, 2000.104 p;

[5] GRANZIERA, Maria Luiza Machado. Direito das Águas: Disciplina Jurídica das Águas Doces. 1. ed. São Paulo: Atlas, 2001. 245 p;

[6] LEAL, M. S. Gestão de Recursos Hídricos por Bacias Hidrográficas: sugestões para o modelo brasileiro. 1997. 228 f. Dissertação (Mestrado em Engenharia) - Universidade Federal do Rio de Janeiro COPPE/U FRJ, Rio de Janeiro, 1997;

[7] MACHADO, Paulo Affonso Leme. Direito Ambiental brasileiro. 11. ed. São Paulo: Malheiros Editores Ltda., $2003.1064 \mathrm{p}$;

[8] MILARÉ, Edis. Direito do Ambiente: doutrina - prática - jurisprudência - glossário. 2 ed. São Paulo: Revista dos Tribunais, 2000, p. 126;

[9] MMA /ANA - Ministério do Meio Ambiente/Agência Nacional de Águas. Outorga de direito de uso de Recursos Hídricos. Brasília: 2000a. Disponível em: HTTP//200.252.222.100/Instrumentos/Outorga/índex.htm. Acesso em 27 de dezembro de 2000a. Tese doutorado - Universidade Federal de Santa Maria, 2004;

[10] POMPEU, Cid Tomanik. Direito de Águas no Brasil. São Paulo: Revista dos Tribunais, 2006. 512 p;

[11] ___. Autorização administrativa. São Paulo: Revista dos Tribunais,1992;

[12] SERGIPE. Lei ${ }^{\circ} 3.870$ de 25 de setembro de 1997. Disponível em: http://www.semarh.se.gov.br/srh/modules/tinyd0/index.php?id=7. Acessado em: 13 de ago. 2013;

[13] SILVEIRA, G. L., ROBIANA, A. \& GIOTTO, E. Outorga para Uso dos Recursos Hídricos: aspectos práticos e conceituais para o desenvolvimento de um sistema informatizado. Revista Brasileira de Recursos Hídricos/Associação Brasileira de recursos Hídricos, Porto Alegre, v.3, n. 3, jul./ set, p. 05-16, 1998. Tese doutorado - Universidade Federal de Santa Maria, 2004;

[14] ___. Decreto 18.456 de 03 de dezembro de 1999. Disponível em: http://www.semarh. 


\title{
Capítulo 5
}

\section{Uso múltiplo da água no baixo São Francisco: A navegação e seus (des)dobramentos}

\author{
Adriano Morais Araujo \\ Antenor de Oliveira Aguiar Netto
}

Resumo: O rio São Francisco conhecido como rio da integração nacional, possui uma forte ligação com a navegação. Sua história é marcada pelo uso contínuo das águas como elemento de conexão entre o Norte e o Sul do país criando e fortalecendo vias de comunicação, fixação e aproveitamento dos recursos naturais. 0 trabalho intitulado "Uso múltiplo da água no baixo São Francisco: A navegação e seus (des)dobramentos", tem como objetivo geral analisar se a multiplicidade do uso da água pautada pela Lei $\mathrm{n}^{0}$ 9.433/97 se aplica a navegação. Para verificar os tipos de usos e se a navegação está contemplada nesse recorte fisiográfico da bacia hidrográfica foi selecionada uma parte do curso navegável. A barragem da hidroelétrica de Xingó foi o ponto inicial dessa viagem que finalizou no trecho entre o povoado Niterói em Sergipe e o município alagoano de Pão de Açúcar. A navegação sofre constantemente os efeitos das variações de vazão, dificultando ou impedindo totalmente o seu uso, principalmente em embarcações de maior calado. Os pescadores dos municípios visitados foram fundamentais para o desenvolvimento da pesquisa, pois, diariamente executam suas atividades lobarais, portanto possuem um profundo conhecimento e uma aguçada percepção das nuances do rio (antes e depois dos barramentos). A fala dessas comunidades converge para as dificuldades da navegação, principalmente a partir da construção das hidroelétricas e outras obras hidráulicas ao longo do rio São Francisco. Entre os principais problemas levantados foram encontrados: a concentração de lodo, aparecimento de pedras, formação de bancos de areia e croas e a diminuição na produção de peixes. Esses impactos provocam diversos prejuízos para as comunidades locais, desencadeando um emaranhado de conflitos.

Palavras-chave: Água, navegação, barramentos e rio São Francisco. 


\section{INTRODUÇÃO}

"A água é o princípio de todas as coisas", assim dizia o filósofo grego Tales de Mileto. Isso, a define como um recurso indispensável para a manutenção da vida e das mais diversas atividades humanas. Como a água faz parte de diversos elementos do planeta seria ela então um elo marcante em diversas paisagens, compondo assim diversas estruturas de construção e resignificação.

A pesquisa considerou a priori a "paisagem" como locus a partir da explicação de Bertrand (1972) que afirma ser essa "o resultado da combinação dinâmica, portanto instável, de elementos físicos, biológicos e antrópicos que, reagindo dialeticamente uns sobre os outros, fazem da paisagem um conjunto único e indissociável, em perpétua evolução". Consequentemente a bacia hidrográfica seria então um mosaico de paisagens.

A bacia hidrográfica representa os diversos elementos e suas relações de forma macro, no entanto, esse aspecto não deve sobrepor às particularidades físicas de cada paisagem e sua capacidade de gerar novos espaços e potenciais conflitos.

O território de uma bacia hidrográfica e as relações de poder estabelecidas na paisagem deve ser constituído de espaços múltiplos que permitam aos diferentes atores os mais diversos usos. A bacia hidrográfica é um espaço de multiplicidades, sendo, logo, um espelho das apropriações realizadas dentro do tempo e do espaço.

Segundo Aguiar Netto e Pinto (2008), a bacia hidrográfica é uma unidade de organização aberta "resultante da interação das ações humanas com os elementos e formas do meio físico e, dentre estes, em especial, a disponibilidade e qualidade das águas", desta maneira, de fácil transformação e (re) significação devido a sua interelação com os diversos elementos naturais e antrópicos.

Dentro dessa lógica de apropriação de uma bacia hidrográfica, a navegação surge como um importante elemento, uma vez que estabelece vínculos, sejam eles de ordem econômica, cultural, histórica e social. Essas interações provocam diferentes demandas, sendo então necessária uma profunda articulação objetivando compatibilizar o uso, o controle e a proteção dos recursos ambientais, como preconiza (FREITAS, 2000). Tal disciplina facilitaria os usos múltiplos e a redução de conflitos.

0 uso sustentável de uma bacia hidrográfica deve priorizar princípios ligados à harmonia entre os atores, a participação social e a divulgação de informações. A cooperação deve eleger a equidade como um pilar de uma gestão de bacias garantindo o direito à informação, transparência e responsabilidade compartilhada na gestão dos recursos naturais, através do princípio e "democracia ambiental", como enfatiza Leite (2015), elemento de suma importância para o funcionamento das instituições que norteiam a gestão dos recursos hídricos, a gestão de pessoas e de outras atividades como a irrigação, a produção de energia, a memória, a pesca e a navegação.

Assim, para compreender esses movimentos estabelecidos entre os usos múltiplos e a navegação, dividimos o trabalho nas seguintes etapas: a primeira parte apresenta as bases teóricas que sustentam as categorias principais, a saber: baixo São Francisco, navegação, pesca artesanal, legislação de recursos hídricos, condicionantes ambientais, fatores antrópicos, a história da navegação e os elementos ligados à gestão da bacia hidrográfica. No segundo momento estão descritos os meios utilizados na pesquisa, expondo pela lente dos pescadores os desdobramentos que envolvem a navegabilidade no trecho que delimitado pelos municípios de Canindé de São Francisco, Piranhas, Poço Redondo e Pão de Açúcar no baixo São Francisco.

Os pescadores foram consultados, pois, segundo Faggionato (2011) o sentimento de pertencimento e a identidade local são definidos como uma tomada de consciência do ambiente pelo homem ao aprender, ao proteger e ao cuidar do mesmo. E para isso, a navegação desempenhou um papel de destaque no processo de ocupação e desenvolvimento em toda a paisagem que forma a bacia hidrográfica do rio São Francisco.

No terceiro momento, apresento uma síntese dos resultados e discussões, assinalando que com o passar dos anos a capacidade de navegabilidade e a pesca no leito do rio São Francisco foram comprometidas pela ação direta das barragens do setor elétrico. Segundo a vasta literatura, as barragens das hidroelétricas sobre controle da Chesf afetaram a dinâmica natural do rio desencadeando uma vasta quantidade de impactos que modificaram a rotina da navegação e da pesca. E por último, as considerações finais.

Mediante as apresentações, este trabalho teve como objetivo geral analisar se a multiplicidade do uso das águas no baixo São Francisco pautada pela Lei no 9.433/97 se aplica as diferentes modalidades de navegação. 


\section{MATERIAL E MÉTODOS}

\subsection{LOCALIZAÇÃO E CARACTERIZAÇÃO DA ÁREA DE ESTUDO}

O Plano de Recursos Hídricos da bacia hidrográfica do rio São Francisco, indica que a bacia é dividida em quatro setores fisiográficos: 0 alto São Francisco com 16\% da área total, o médio com 63\%, o submédio com 17\% e o baixo São Francisco com apenas 4\% PRHSF (2015). A área de estudo dessa pesquisa é o baixo São Francisco que, segundo o caderno de Recursos Hídricos da ANA (2005) possui um estirão navegável de $208 \mathrm{~km}$ estendendo-se da foz no Oceano Atlântico até a cidade alagoana de Piranhas Alagoas. Esse trecho é majoritariamente utilizado por embarcações turísticas e pequenos barcos de pesca.

Figura 1 - Mapa de localização do baixo São Francisco em Alagoas e Sergipe - Brasil.

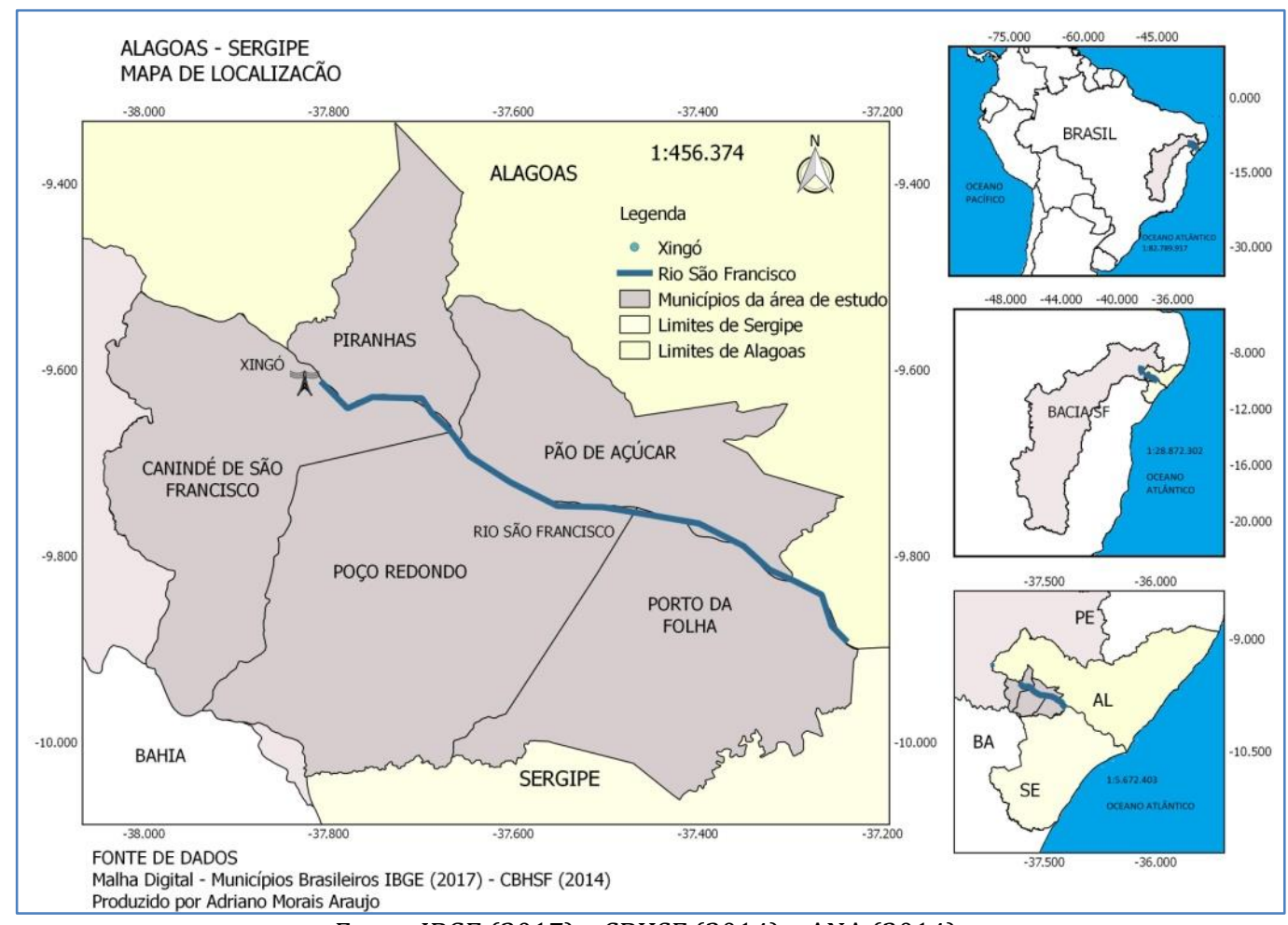

Fonte: IBGE (2017) - CBHSF (2014) - ANA (2014).

Em virtude da logística, foi necessário reduzir a área da pesquisa, tomando a barragem da Hidroelétrica de Xingó como ponto inicial, perfazendo aproximadamente um trecho de $31 \mathrm{~km}$ equivalente a $14 \%$ do trecho navegável do Baixo São Francisco.

A área de estudo está inserida na região de clima semiárido que segundo Santos (2018), possuem "chuvas irregulares durante o ano e se concentram num período de aproximadamente quatro meses". A vegetação predominante no local é a caatinga. Sobre esse ponto Zappi (2008) enfatiza que "a caatinga possui espinhos acúleos que controlam a perda de água por transpiração permitindo a sobrevivência da planta em ambiente de clima semiárido".

De acordo com Melo (2008), "em virtude da ação erosiva das águas do rio São Francisco as regiões ribeirinhas constituem o chamado Plano Aluvial, que são áreas baixas e planas que ocorrem ao longo dos vales, englobando as formas resultantes da deposição, onde predomina o escoamento superficial".

Consta no Sistema Brasileiro de Classificação de Solos da Embrapa (2006) que na área em questão predominam os solos luvissolos háplicos, os planossolos háplicos e os neossolos regolíticos, sendo esses de textura normalmente arenosa, propensos à erosão nas áreas de maior declividade e por consequência a perda do solo. 
A pobreza nos sertões é recorrente e remonta ao período da ocupação da região. Tal cenário ainda é evidente e resulta na formação de espaços de desigualdades sociais que alimentam o uso desordenado dos espaços e dos recursos. Nessa conjuntura, a chegada da Usina Hidroelétrica de Xingó na década de 1980 promoveu o crescimento da renda. Os dados do IBGE na Tabela 1 abaixo confirmam tal verificação.

Quadro 1: Características sociais e geográficas dos municípios da área de estudo.

Fonte: IBGE e Atlas do desenvolvimento humano do Brasil.

\subsection{COLETA E ANÁLISE DAS INFORMAÇõES}

Para desenvolver essa pesquisa foi necessário o levantamento e a consulta a diversos trabalhos acadêmicos realizados pelas instituições de ensino e pesquisa espalhados pelo país.

A pesquisa realizada possui caráter qualitativo, pois aborda a percepção de indivíduos que estão conectados diretamente a bacia do hidrográfica do rio São Francisco e a navegação no seu leito. Portanto, para fundamentar o trabalho, deve-se destacar a seguinte característica:

[...] a pesquisa qualitativa trabalha com o universo de significados, motivos, aspirações, crenças, valores e atitudes, o que corresponde a um espaço mais profundo das relações, dos processos e dos fenômenos que não podem ser reduzidos à operacionalização de variáveis. Aplicada inicialmente em estudos de Antropologia e Sociologia, como contraponto à pesquisa quantitativa dominante, tem alargado seu campo de atuação a áreas como a Psicologia e a Educação. A pesquisa qualitativa é criticada por seu empirismo, pela subjetividade e pelo envolvimento emocional do pesquisador (MINAYO, 2001, p. 14).

A figura humana não pode ser desvinculada da pesquisa. Portanto, para enriquecer o método e compreender a relação estabelecida entre o homem e o meio, será necessária a aplicação de um questionário que segundo Marconi e Lakatos (2010), propõe a "investigação social, para a coleta de dados ou para ajudar no diagnóstico ou no tratamento de um problema social”. O mesmo dar-se-á no método survey, que segundo Gil (2010) é caracterizado pelos questionários com interrogação direta do entrevistador, é feita mediante uma análise quantitativa, ou seja, sem a identificação do indivíduo questionado. Ela pode ser definida como uma forma de coletar dados e informações a partir de características e opiniões de grupos de indivíduos. 0 resultado encontrado, desde que o grupo seja representativo da população, pode ser extrapolado para todo o universo em estudo.

A amostragem da pesquisa levou em consideração a existência das colônias de pescadores da área de estudo, sendo assim selecionadas: Poço Redondo-SE (Z-21) e a Colônia de pescadores do município de Piranhas-AL (Z-30).

A pesquisa de campo foi realizada entre os dias 26/09/18 a 18/01/2019, totalizando 23 viagens entre os municípios de Canindé de São Francisco, Piranhas, Poço Redondo, Pão de Açúcar e Porto da Folha. 
Quadro 2: Dados das colônias de pescadores Z-21 e Z-30 e povoados de aplicação dos questionários na área de estudo.

\begin{tabular}{|l|c|c|c|}
\multicolumn{1}{|c|}{ Colônia } & Município & Associados & Povoados \\
\hline Z-21 & Poço Redondo - SE & 472 & Cajueiro, Jacaré, Curralinho e Bonsucesso \\
\hline Z-30 & Piranhas - AL & 217 & Piranhas Velha e Entremontes \\
\hline
\end{tabular}

Fonte: Colônia Z-21 e Z-30.

Desse modo, atribuindo $10 \%$ de erro amostral com uma população total de 689 pescadores, conclui-se que para atender as necessidades da pesquisa seria necessária uma amostragem de 87,3 questionários. Para tal, foram aplicados 103 questionários distribuídos da seguinte forma (1) e (2):

$$
\begin{aligned}
& n_{0=\frac{1}{E_{0}}} \\
& n=\frac{N \cdot n_{0}}{N+n_{0}}
\end{aligned}
$$

Quadro 3: Informações sobre o quantitativo de questionários e seus locais de aplicação dentro da área de

\begin{tabular}{|c|c|c|c|c|}
\hline Colônia & Município & Amostragem & Quan & \\
\hline \multirow{4}{*}{$\mathrm{Z}-21$} & \multirow{4}{*}{ Poço Redondo - SE } & \multirow{4}{*}{70} & Pov. Cajueiro & 9 \\
\hline & & & Pov. Jacaré & 3 \\
\hline & & & Pov. Curralinho & 42 \\
\hline & & & Pov. Bonsucesso & 16 \\
\hline \multirow{2}{*}{ Z-30 } & \multirow{2}{*}{ Piranhas - AL } & \multirow{2}{*}{33} & Pov. Piranhas Velha & 12 \\
\hline & & & Pov. Entremontes & 21 \\
\hline \multicolumn{2}{|l|}{ TOTAL } & 103 & & \\
\hline
\end{tabular}
estudo.

Fonte: Os autores.

A navegação dos trechos selecionados do rio São Francisco teve como objetivo a observação dos pontos mencionados pelos pescadores artesanais e mestres canoeiros nas entrevistas realizadas. A observação desses locais é de fundamental importância, pois a paisagem é um processo, e como processo possui diversas influências, como bem enfatizado no trecho a seguir:

É uma porção do espaço caracterizado por um tipo de combinação dinâmica, e, portanto instável, de elementos geográficos diferenciados físicos, biológicos e antrópicos - que, ao atuar dialeticamente uns sobre os outros, fazem da paisagem um conjunto geográfico indissociável que evolui em bloco, tanto sob o efeito das interações entre os elementos que a constituem como sob o efeito da dinâmica própria de cada um dos elementos considerados separadamente (BERTRAND, 1968, p. 12).

Todas as observações realizadas nos trechos navegáveis levaram em consideração as informações disponíveis no "Sistema de Informação - Portal HidroWeb" (Agência Nacional de Águas). As vazões de referência para os registros, observações e percepções quanto à navegabilidade foram consultadas nas estações fluviométricas de Piranhas (49330000) e Pão de Açúcar (49370000), sendo as médias encontradas de $621,20 \mathrm{~m}^{3} / \mathrm{s}$ e $677,82 \mathrm{~m}^{3} / \mathrm{s}$ respectivamente. 


\section{RESULTADOS E DISCUSSÃO}

\subsection{HISTÓRIA DA NAVEGAÇÃO NO BAIXO SÃO FRANCISCO}

A navegação no rio São Francisco é marcada por histórias de grandes passagens. Uma das mais célebres foi realizada no ano de 1859 pelo Imperador D. Pedro II com destino as cachoeiras de Paulo Afonso no estado da Bahia. Mais tarde, segundo Costa (2006, no prelo) no ano de 1879, foi realizada pelo engenheiro Teodoro Sampaio uma viagem no vapor Juquiá e o Sinimbu para reconhecimento das condições de navegação do rio.

Os vapores dominaram por muitos anos o setor de transporte de pessoas entre as cidades de Piranhas e Penedo. Porém, com o advento das rodovias o sistema de transporte fluvial foi perdendo espaço. Diegues (1980) destaca que na segunda metade do século XX, o transporte fluvial entrou em processo de decadência com a construção de rodovias e ferrovias, e Penedo foi perdendo gradativamente sua importância no cenário econômico, diminuindo o fluxo de viagens que modificou toda a economia do baixo São Francisco. Assim, os navios a vapor acabaram aos poucos permanecendo apenas no imaginário dos moradores mais antigos dessas povoações.

A redução das viagens dos navios a vapor que transportavam pessoas, serviços postais e mercadorias até as primeiras décadas da segunda metade do $\mathrm{XX}$, acabaram dando sobrevida às canoas de tolda que possuíam custo menor e maior agilidade no rio em comparação aos vapores. A canoa sergipana transportava de tudo, desde arroz a carga viva, desde algodão a lenha. Elas variavam de tamanho e capacidade de carga "as pequenas carregavam entre 400 a 500 sacos. Tinha delas que levava 600 sacos" (Questionário 62 - Colônia Z-21).

A segunda metade do século XX determinou o declínio das embarcações a vapor e a "pano" no baixo São Francisco. A partir da década de 1950, as canoas de tolda começavam a subir o rio para as regiões do submédio e médio São Francisco e as dificuldades de navegação e de oferta de trabalho podem ter incentivado a migração naval.

O "mestre Cornélio" foi enfático ao dizer "trabalhei muitos anos no Juazeiro colocando motor nas toldas, era cada canoa grande que o mastro quase topava na ponte". Corroborando com a fala do mestre Cornélio, Selling Junior (1976) descreve que as canoas começaram a migrar para a região de Juazeiro a partir da década de 1940. Ela possuía vantagens na velocidade e na facilidade de manobra "eram fortes concorrentes dos vapores, com os quais podiam competir em velocidade e, não raro vencê-lo na corrida, tomando assim parte ponderável da carga disponível".

0 destino das canoas dos quadros acima é desconhecido, entretanto, os diversos relatos dos entrevistados e dos mestres canoeiros apontam para o afundamento, colocação em terra e a motorização. "Algumas afundaram, a maioria virou foi lenha. A Paladina tá lá em Bonsucesso. Outras eu levei cortada no trem pra Juazeiro. Aqui eu mudei muitas pra botar motor". (Cornélio, Mestre).

O declínio das canoas de Tolda e a sua curta migração para o submédio do São Francisco estão vinculados às mudanças na logística econômica "depois que construíram as estradas de barro se acabou foi tudo" (Cornélio, Mestre), e na dinâmica das vazões, fator esse intensificado a partir das construções das barragens do Complexo Hidroelétrico de Paulo Afonso - BA e da Usina Hidroelétrica de Xingó - AL/SE.

A série histórica abaixo registra as cinquenta piores médias de vazões no município de Piranhas - AL. Os valores indicam que a década de 1950 apresentou baixos níveis de vazão que provavelmente incentivou a migração para o médio São Francisco. Sobre esse assunto:

a redução da variabilidade interanual e da magnitude da vazão demonstra que o Rio São Francisco sofreu drástico decréscimo na variabilidade sazonal da vazão. Os picos de enchentes com vazões altas que ocorriam naturalmente nos primeiros meses do ano (janeiro a março) foram notavelmente reduzidos, com exceções das vazões que ultrapassaram a capacidade limite de controle das barragens, mas isso não ocorre com frequência. (ARAUJO, AGUIAR NETTO e GOMES, 2016, p. 243).

As reduções dos picos de enchentes com altas vazões apontadas por Aguiar Netto e Araujo (2016), podem ser evidenciadas pela série histórica na figura 2. O período entre 1951-1959, 1973-1977 e 1977-2003 estão vinculados a construção e operação das barragens do Complexo Paulo Afonso, Sobradinho e Xingó, apontado por Martins et al (2011), como os responsáveis pelas modificações mais significativas no regime de vazões do Rio São Francisco - Três Marias (1952) e Sobradinho (1979), localizados nos Estados de 
Minas Gerais e Bahia, que têm as funções de geração de energia e controle de cheias. Portanto, os grandes barramentos provocariam mudanças no regime de vazões para fins de geração de energia, constituindo uma fonte potencial de conflito para os diferentes usos em especial para a navegação nas águas da bacia hidrográfica do rio São Francisco. A respeito da importância da navegação Almeida (2018) aponta a relevância dos projetos do governo brasileiro para ampliar o sistema de transportes na bacia hidrográfica. Destaca o autor que o Ministério do Transportes (2013) apresentou o Plano Hidroviário Estratégico (PHE), aspirando ao desenvolvimento do potencial de navegação interior, pretendendo reduzir os custos com transportes.

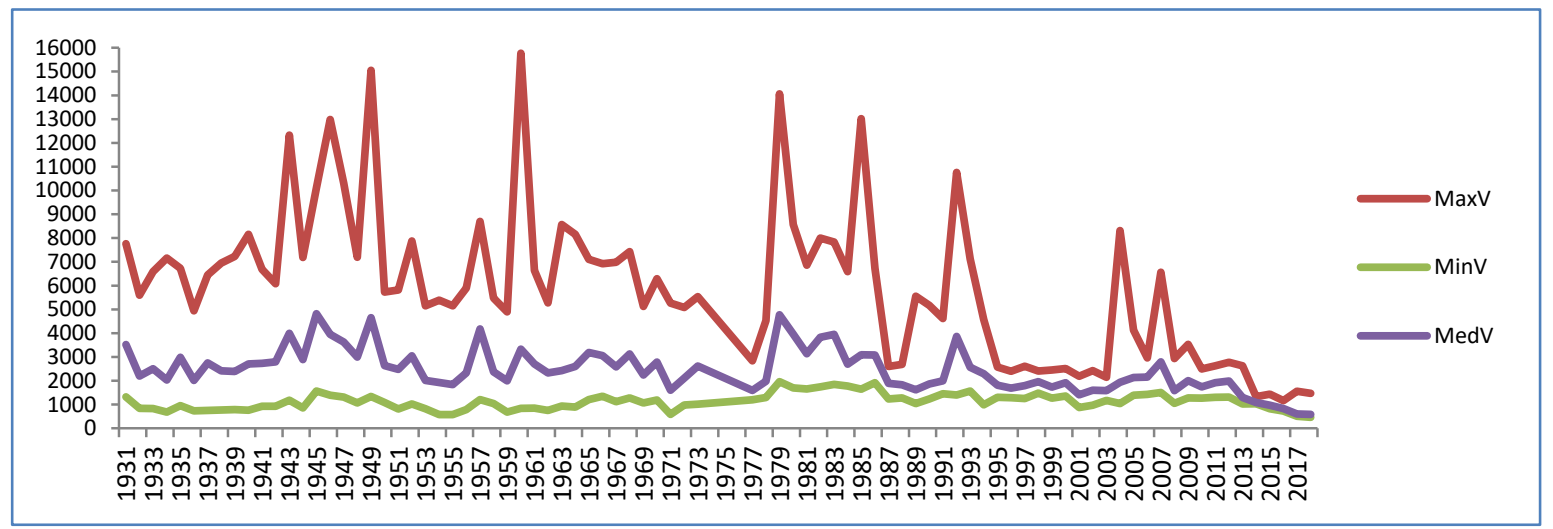

Figura 2 - Levantamento das médias de vazão registradas entre 1931-2018 na estação 49330000 localizada no município de Piranhas-AL.

Fonte: HidroWeb (ANA).

As reduções dos picos de vazão alimentam uma série de transformações no baixo São Francisco, reduzindo sua navegabilidade e contribuindo para o desaparecimento gradual das embarcações a "pano" a jusante da barragem de Xingó.

\subsection{NAVEGAÇÃO: CAMINHOS E DIFICULDADES}

As transformações são sentidas pela maioria dos entrevistados em virtude do contato direto com o trabalho e o rio. Os pescadores possuem saberes e vivência que foram construídas ao longo dos anos, sobre essas visões, os órgãos de representatividade e gestão da bacia devem levar em consideração a importância dessas comunidades tradicionais, visto que, segundo Fernandes Pinto e Marques (2004) "as práticas de comunidades tradicionais como a de pescadores, tornam-se importantes ferramentas para os estudos conservacionistas, auxiliando no conhecimento da flora, fauna e ecologia dos ambientes", tornando necessária a avaliação e consideração desses saberes.

Figura 3 - Percepção dos pescadores artesanais de Piranhas e Poço Redondo sobre as mudanças ocorridas no trecho navegável do rio São Francisco.

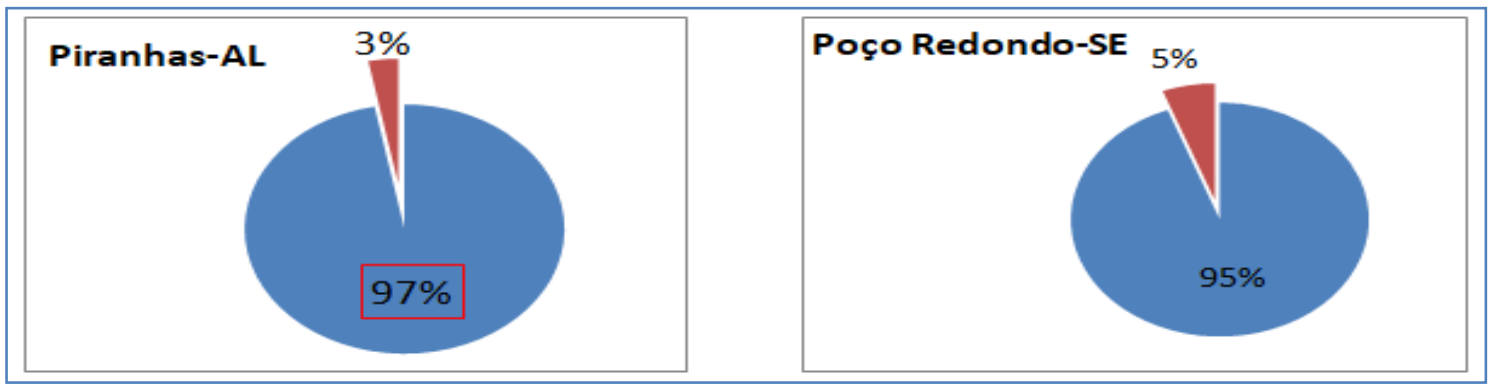

Fonte: Os autores 
Uma das atividades vinculadas a pesca artesanal é a prática amadora da navegação. Observa-se que com a regularização e redução da vazão o rio passa a revelar acidentes geográficos que dificultam a navegação deixando os pescadores em alerta a partir da redução das vazões, "eu nunca vi tanta pedra como agora" (Damião, mestre). Na região de Piranhas, $12 \%$ dos entrevistados relataram não observar mudanças que alterem a prática da navegação.

Do total de pescadores, 34\% em Piranhas e 25\% em Poço Redondo acompanharam as alterações desde o início das operações em Sobradinho, consequentemente esse público possui maiores percepções a cerca das mudanças do rio São Francisco.

Segundo Medeiros et. al (2007) "as diversas barragens em cascata construídas ao longo do tempo, desde a década de 1970, provocaram grandes modificações da pulsação natural e nas vazões interanuais do médio e baixo São Francisco" produzindo assim a redução da velocidade da corrente e a quantidade de sedimentos transportados, desenvolvendo uma biota lêntica. Essa característica provocou a formação de grande concentração de vegetação chamada pelos pescadores de "lodo", tornando-se um elemento que dificulta a navegação no trecho entre os Povoados Entremontes em Alagoas e a cidade de Pão de Açúcar. Segundo os entrevistados, esse material é produzido pela falta de correnteza no rio, além do acúmulo de resíduos orgânicos dos povoados. O "lodo" provoca diversos problemas como forçar o motor, enroscamento nas hélices e até impactos paisagísticos, contribuindo para a diminuição do fluxo de turistas nas praias dos povoados Jacaré e Curralinho.

Figura 4 - Registro das alterações que afetam a navegação no trecho navegado do rio São Francisco.

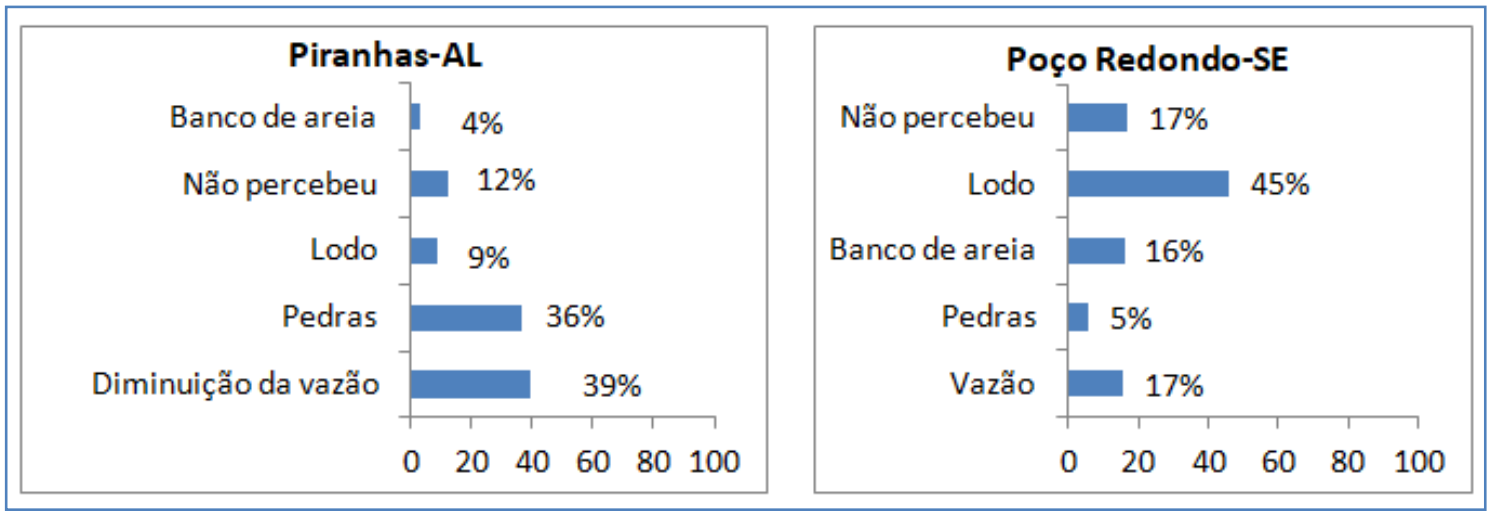

Fonte: Os autores

A respeito do "lodo", Santana (2017) indagou um grupo de indivíduos no baixo São Francisco sobre as vegetações aquáticas que mais afetavam a navegação e a pesca, sendo apontados, portanto, as seguintes espécies de macrófitas aquáticas: Egeria densa, a Eichhornia crassipes e a Derbesia tenuissima.

Figura 5 - "Lodo" preso na hélice e acumulado em diversos pontos do trecho navegável da pesquisa.

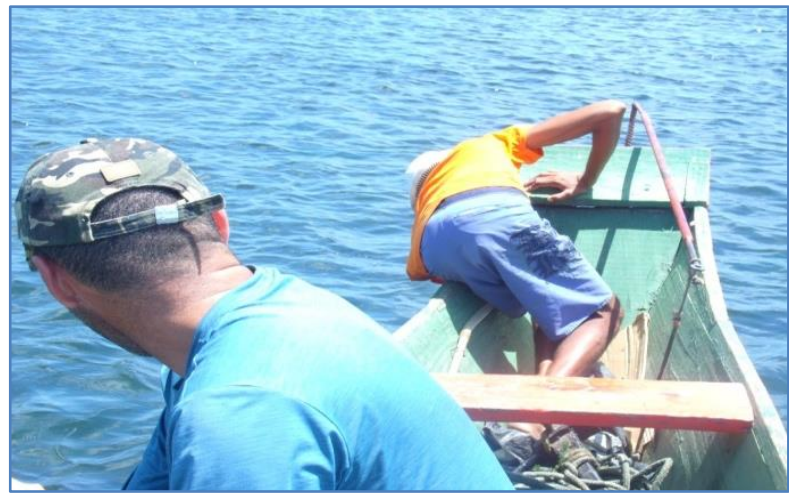

Fonte: Os autores. 
Araújo (2015) enfatiza que a regularização da vazão das águas do rio São Francisco e sua consequente redução dos valores máximos e aumento dos valores mínimos, não permite que o rio "viva" naturalmente. Este se mantém com características de ecossistema de águas com baixo fluxo, contribuindo para o crescimento de macrófitas e outros elementos que desgastam a dinâmica do rio. "Todo mundo aqui já teve hélice quebrada, casco, eixo empenado e já perdeu rede. Quem disser o contrário tá mentindo" (Questionário no 58 - Colônia Z-2). Esse discurso é frequente entre os pescadores e navegantes no trecho que compreende a cidade de Piranhas até os povoado de Poço Redondo.

Figura 6 - Prejuízos identificados pelos pescadores durante a navegação.
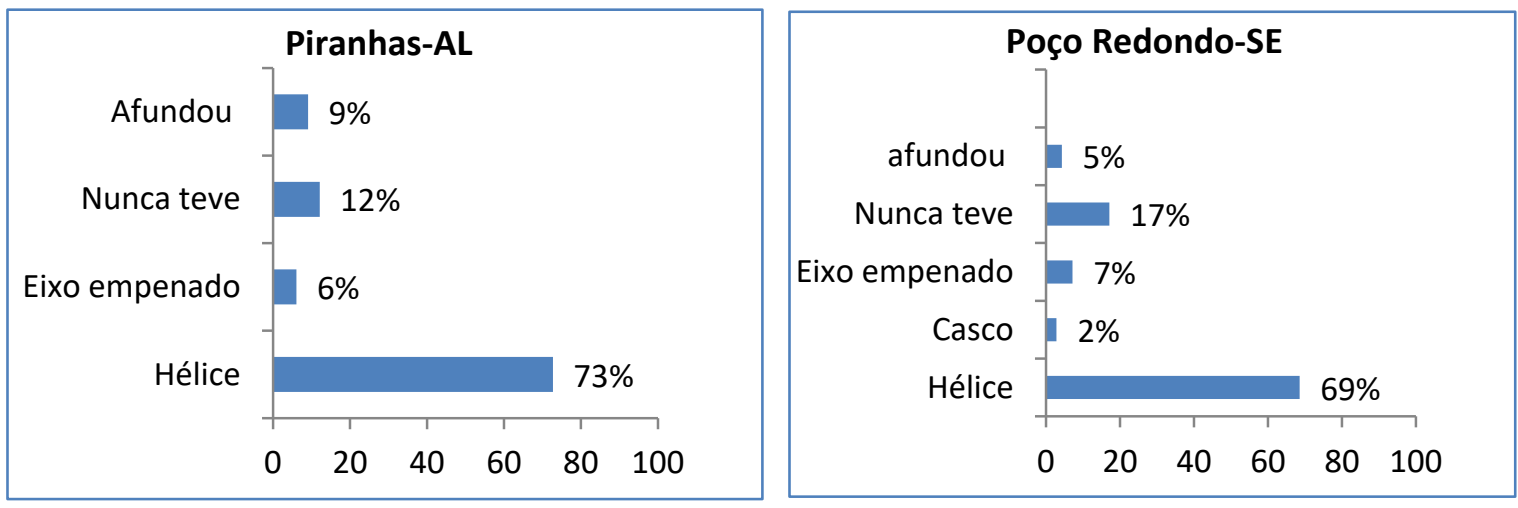

Fonte: Os autores.

Os prejuízos são produzidos principalmente pela colisão com rochas e pelo acúmulo do "lodo" nas hélices. Como o custo com a troca desse equipamento é elevada, os pescadores passaram a utilizar materiais de baixa qualidade para baratear os custos: "você vai ali na Ilha do Ferro e vai ver o pessoal derretendo latinha de cerveja e refrigerante pra fazer hélice" (Belão, mestre). A quebra das hélices é tão rotineira que ao serem questionados os pescadores não mais mencionavam a hélice como prejuízo, denotando uma naturalização desse efeito.

Os registros indicam que alguns pescadores estão mudando hábitos como velocidade e distanciamento dos pontos de pesca. Muitos alegaram que não encostam mais nos paredões, locais apontados como de alta incidência de peixes maiores devido a profundidade desses pontos.

Figura 7 - Piores trechos para navegar segundo os pescadores das colônias de Piranhas e Poço Redondo.
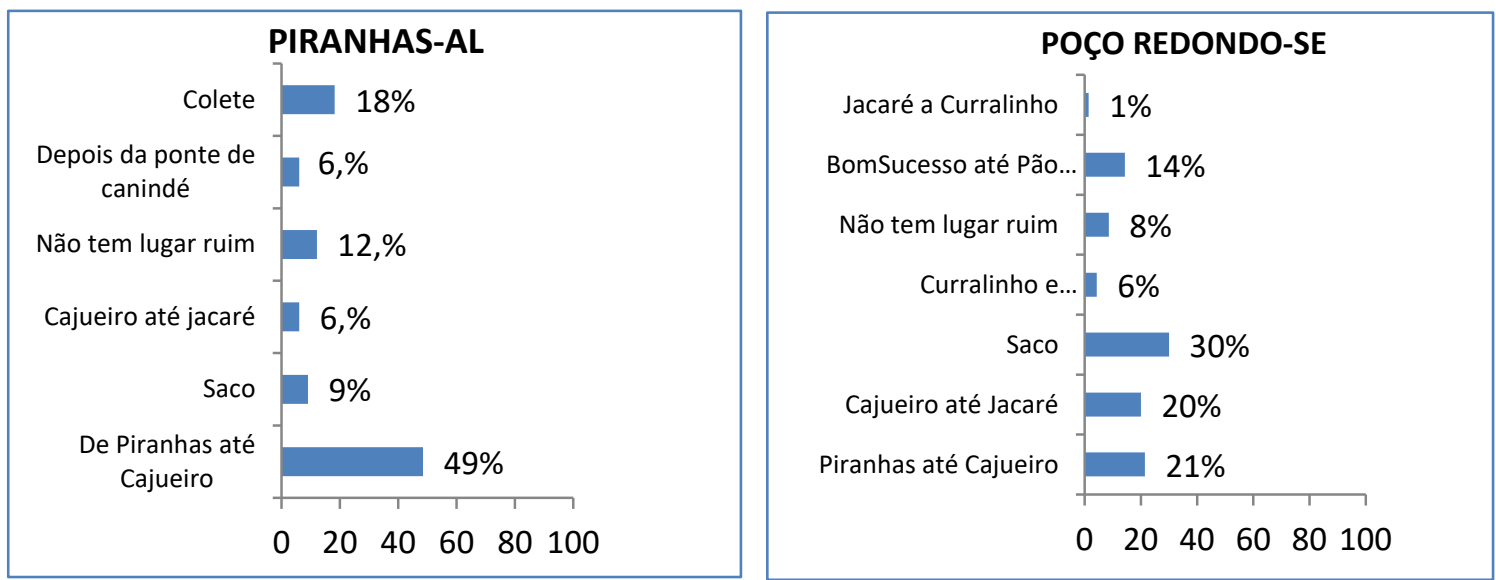

Fonte: Os autores.

Os pescadores de Piranhas apontam o trecho até o povoado Cajueiro (Poço Redondo) como o mais complicado. Esse trecho é marcado por uma grande quantidade de pedras que contribuem para a 
formação de redemoinhos. Os pescadores dos povoados Cajueiro, Jacaré, Curralinho e Bonsucesso, indicam que os piores trechos estão justamente na sua área de atuação por causa dos bancos de areia e pela concentração do "lodo". Como muitos se deslocam para montante do rio, 41\% deles apontaram o trecho Jacaré-Piranhas como o mais complicado em virtude dos afloramentos e o afunilamento do canal do rio.

A movimentação das águas realizada pelo constante fluxo de embarcações turísticas proporciona a formação de ondulações que aceleram a erosão e sedimentação nos depósitos aluvionais existentes nas margens do rio. Esse processo, combinado com o desmatamento da caatinga e a redução da vazão contribuem para a consolidação e o crescimento de banco de areia na calha do rio São Francisco.

Figura 8 - Efeito das "maruadas" na erosão das margens aluviais do rio São Francisco.

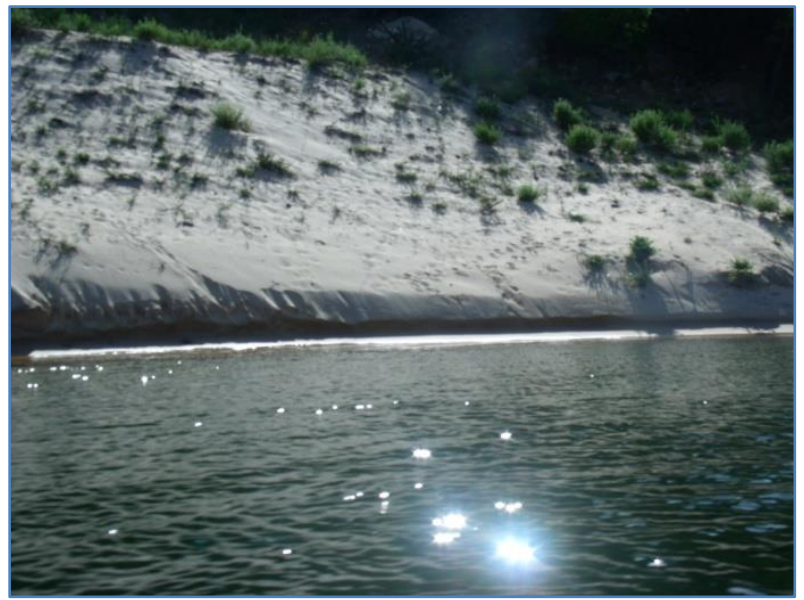

Fonte: Os autores.

Syvitski et al. (2005), Song et al. (2007), Stevaux et al. (2008) e Zahar et al. (2008) reforçam que os impactos gerados pela construção de barragens em um rio provocam alterações na quantidade e qualidade da água, assim como na peridiocidade das cheias. Os efeitos diretos à jusante dos reservatórios são: redução do número de espécies de peixes e invertebrados, redução dos níveis de deposição de sedimentos e nutrientes na planície de inundação, impedimentos à navegação, alterações nos processos biofísicos dos estuários, redução da recarga subterrânea e comprometimento da disponibilidade hídrica para os múltiplos usos.

Quando questionado sobre reuniões ou visitas realizadas pela CODEVASF, Chesf ou CBHSF, os entrevistados apontam que são realizadas apenas para informes da CODEVASF e Chesf. O Comitê foi mencionado apenas uma única vez, porém o registro foi notado em uma visita ao povoado Bonsucesso. Segue um relato sobre essa atuação:

"Essa ANA e o Comitê tiveram aqui, olham o rio e vão embora. Antigamente era melhor. A última vez que eu vi a CODEVASF foi pra falar de criatório de peixe. Agora me diga, pra que com um rio desses? A CHESF fazia reunião com a comunidade. Tem mais de três anos que eu vi uma. Eu soube que vem um pessoal aí, mas não sei de onde é. Vai lá pra sede da colônia. A CHESF um tempo desses soltou água aí e nem avisou. Levou tudo do povo rio abaixo. Tá na justiça, mas vai dar nada não. Até canoa afundou" (Questionário no 30 - Colônia Z-21).

O comitê não possui nenhuma representatividade para os ribeirinhos dessa região do rio São Francisco. Essa falta de representatividade real pode ser sentida pela seguinte afirmação: “Comitê, só vejo pela internet" (Questionário no 24 - Colônia Z-30).

$\mathrm{O}$ avanço do turismo como fonte de renda e lazer na região afeta as condições de navegabilidade. 0 fluxo de embarcações é elevado entre Piranhas e os espaços de recreação encontrados nas margens principalmente no município de Poço Redondo. Vários entrevistados relataram já ter se envolvido em algum tipo de acidente por causa dos Catamarãs que provocam a formação das chamadas "maruadas", perturbações na água que formam ondulações aumentando o risco de acidentes. Para minimizar esses transtornos pescadores e empresas de turismo acertaram que as embarcações que provocam maiores 
deslocamentos de água devem reduzir sua velocidade ao avistar embarcações de pescadores e ou empresas de turismo.

\section{CONSIDERAÇÕES FINAIS}

A bacia hidrográfica do rio São Francisco vivenciou momentos de maior aproveitamento do setor da navegação. Todo o século XIX e XX foi palco para as linhas fluviais que ligavam o sertão ao litoral e por consequência as demais regiões litorâneas do país. Vapores, canoas, itas, gaiolas e demais embarcações estavam conectados ao modal rodoviário e ferroviário, mesmo limitado a Penedo e com estradas em precárias condições de utilização. Esse transporte facilitou o desenvolvimento de uma rede de fluxos que formou as principais características econômicas, sociais e ambientais de todo o baixo São Francisco, definindo inclusive estratificações sociais.

Diversos tipos de embarcações navegavam por esse trecho do rio São Francisco, entre elas as que mais se avolumavam e representavam um sistema eficiente de transporte eram as canoas de Tolda. Seu período áureo teve início no século XIX e foi finalizado no século XX, principalmente pelas dificuldades de competição com o setor rodoviário e os efeitos da mudança na dinâmica natural do rio após as sucessivas barragens que foram concluídas após a instalação da hidroelétrica de Xingó, sendo portanto, a motorização e as poucas restaurações o último suspiro para esses tipos de embarcações.

As canoas de Tolda e outras embarcações ligadas às dinâmicas naturais (vazão, vento...) praticamente já desapareceram do cenário do rio, fator esse corroborado pela visão dos pescadores entrevistados que enfatizam as péssimas condições para a navegação, evidenciando que esse setor não necessariamente é contemplado pela legislação vigente no que diz respeito aos usos múltiplos. Todavia, não existe um impedimento total, desde que, a embarcação não seja de grande porte, como reforça o relatório da Sociedade canoa de Tolda que em 2013 limitou o calado a apenas 0,55m.

0 rio apresenta em seu curso um trecho navegável que exige do comandante um conjunto de habilidade para perceber a ocorrência de pedras, principalmente entre os trechos de Piranhas até o povoado Jacaré, em Poço Redondo, que em virtude da reduzida vazão são facilmente visualizadas. Após esse trecho os dois grandes empecilhos para a prática naval são: o "lodo" e os bancos de areia.

Devido ao grande conhecimento gerado pela vivência diária os pescadores não demonstram receio para navegar inclusive à noite. Deve-se destacar que a condição do vento foi apontada como um outro obstáculo para a navegação. Muitos dos entrevistados gostam inclusive de enaltecer o fato de que conhecem a localização de cada pedra existente no rio, realidade diferente para os que utilizam as águas do rio São Francisco esporadicamente.

As condições para a realização da pesca, assim como a navegação, vêm sofrendo mudanças significativas ao longo do tempo. Muitos pescadores apontaram que a situação foi agravada após a construção de Xingó, gerando, portanto, a redução da vazão, a diminuição do número de peixes, a proliferação do "lodo", a consolidação das croas e a formação de novos bancos de areia.

As definições territoriais devem ser um ponto de destaque nas relações existentes dentro desse recorte da bacia hidrográfica. A diminuição da vazão abriu espaço para uma reconfiguração espacial nas margens do rio; as ilhas formadas abriram espaço para ocupações desordenadas que potencializam os conflitos entre pescadores, agricultores e empresas de turismo, que não permitem a utilização desses pontos para reparação das embarcações e outras atividades ligadas a pesca.

O agravamento e o surgimento dos conflitos indicam que existe uma deficiência na comunicação e na efetivação de políticas públicas que promovam o desenvolvimento econômico e ambiental e o fim dos grandes fluxos de grandes embarcações modificou toda a dinâmica econômica da região.

Todos esses fatores (ambientais ou não), afetam o relacionamento estabelecido entre os pescadores e navegantes em relação ao rio São Francisco. Os mesmos não estão inseridos na ótica da gestão colaborativa e participativa da bacia hidrográfica preconizada pela legislação em vigor. 0 distanciamento dos atores piora a situação da navegação na bacia hidrográfica comprometendo a existência de um setor vital e a efetivação dos usos múltiplos da bacia. 


\section{REFERÊNCIAS}

[1] ABERS, Rebecca Neaera (org). Água e política: atores, instituições e poder nos Organismos de Bacia Hidrográfica no Brasil. São Paulo: Annablume, 2010.

[2] ABREU, Capistrano de. Capítulos da História Colonial. 4 ed. Sociedade Capistrano de Abreu, Livraria Briguiet, 1954. p.217/218.

[3] ADMINISTRAÇÃO DA HIDROVIA DO RIO SÃO FRANCISCO (AHESF). São Francisco: Histórico. Disponível em: <http://www.ahsfra.gov.br/?op=conteudo\&id=133\&menuId=165>. Acesso em 21 jan 2019.

[4] AGÊNCIA NACIONAL DE ÁGUAS (ANA) - A navegação interior e sua interface com o setor de recursos hídricos, 2005.

[5] AGÊNCIA NACIONAL DE TRANSPORTES AQUAVÁRIOS (ANTAQ) - Relatório Executivo - Bacia do São Francisco Plano Nacional de Integração Hidroviária, 2013.

[6] ALMEIDA, Flávio Gomes de e PEREIRA, Luiz Firmino Martins. 0 papel da distribuição e da gestão dos recursos hídricos no ordenamento territorial brasileiro. In: SOARES, Luiz Antônio Alves e ALMEIDA, Flávio Gomes de (organizadores). Ordenamento territorial: coletânia de textos com diferentes abordagens no contexto brasileiro. Rio de Janeiro: Bertrand Brasil, 2009. p. 85-110.

[7] ALMEIDA, Carlos Alberto Prata. Prospecção da crise hídrica por meio da modelagem hidrológica no rio São Francisco. 2018. Tese (Doutorado em Desenvolvimento e Meio Ambiente) - Universidade Federal de Sergipe. Orientador: Antenor de Oliveira Aguiar Netto.

[8] ARAUJO, Sérgio Silva de. Apropriação dos recursos naturais e conflitos socioambientais no Baixo São Francisco em Sergipe e Alagoas, 2015. Tese (Doutorado em Desenvolvimento e Meio Ambiente) - Universidade Federal de Sergipe. Orientador: Antenor de Oliveira Aguiar Netto.

[9] ARAUJO, Sérgio Silva; NETTO, Antenor de Oliveira Aguiar; GOMES, Laura Jane. A percepção ambiental, identidade e pertencimento dos moradores do povoado Cabeço, em Brejo Grande/SE, frente às inundações na foz do rio São Francisco. Desenvolvimento e Meio Ambiente (UFPR), v. 36, p. 239-253, 2016.

[10] ARAUJO, Sérgio Silva de; NETTO, Antenor de Oliveira Aguiar; SALES, João Marcos Jesus. O peixe, o pescador e a barragem de Xingó no Baixo São Francisco em Sergipe e Alagoas no Brasil. revIPI. v. 2, 2016.

[11] BERTRAND, Georges. Paisagem e geografia física global: esboço metodológico. Tradução Olga Cruz - Caderno de Ciências da Terra. Instituto de Geografia da Universidade de São Paulo, nำ13, 1972.

[12] BERTRAND, G. Paisagem e Geografia Física Global. Caderno de Ciências da Terra. São Paulo. (13): 1 - 27, 1968.

[13] BRASIL. Constituição (1988). Constituição da República Federativa do Brasil: promulgada em 5 de outubro de 1988. Disponível em: <http://www.senado.gov.br>. Acesso em: 22 dez 2017.

[14] BRASIL. Lei n. 9.433, de 8 de janeiro de 1997. Torna obrigatório a Política Nacional de Recursos Hídricos. Disponível em: <http://www.planalto.gov.br/ccivil_03/LEIS/L9433.htm>. Acesso em: 01 mai 2018.

[15] CARVALHO, Márcia Eliane Silva. Um olhar geográfico sobre as águas no Vaza Barris sergipano. São Cristóvão: Editora UFS, 2014, 312 p.

[16] CASADO, Ana Patrícia Barreto; HOLANDA, Francisco Sandro Rodrigues; ARAÚJO FILHO, F. A. G; YAGUIU, P. Bank erosion evolution in São Francisco River. Revista Brasileira de Ciência do Solo, Viçosa, v.26, p.231-239, 2002.

[17] CÂMARA. Antônio Alves. Ensaio sobre as construções navais indígenas do Brasil. Rio de Janeiro: Papelmaça edições, 1888.

[18] COMITÊ DA BACIA HIDRGRÁFICA DO RIO SÃO FRANCISO. Resumo Executivo do Plano de Recursos Hídricos da Bacia Hidrográfica do Rio São Francisco 2016-2025. Alagoas, 2016.

[19] COSTA, Alcino Alves. Canoas: 0 caminho pelas águas. Poço Redondo, 2006. No prelo.

[20] DIEGUES JR., M. O Banguê das Alagoas - Traços da Influência do Sistema Econômico do Engenho de Açúcar na Vida e na Cultura Regional. Maceió: EDUFAL, 1980.

[21] EMBRAPA. Centro Nacional de Pesquisa de Solos (Rio de Janeiro, RJ). Sistema Brasileiro de classificação de solos. 2. ed. - Rio de Janeiro: EMBRAPA-SPI, 2006.

[22] FAGgionATO, Sandra. Percepção ambiental. Materiais e Textos, 2011. Disponível em: <http://educar.sc.usp.br/biologia/textos/m_a_txt4.html>. Acesso em: 24 dez 2018.

[23] FERNANDES PINTO, Érika; MARQUES, José Geraldo Wanderley. Conhecimento etnoecológico de pescadores artesanais de Quaraqueçaba - PR. Enciclopédia Caiçara, v. 1, 382, 2004. 
[24] FREITAS, Adir José. Gestão de recursos hídricos. IN: Gestão de recursos Hídricos - Aspectos legais, econômicos, administrativos e sociais. Org: SILVA, Demetrius D. e PRUSKI, Fernando F. UFV e ABRH, Porto Alegre, 2000. P. 1117.

[25] GIL, Antônio Carlos. Métodos e Técnicas de Pesquisa Social. 6 ed. São Paulo: Atlas, 2010.

[26] IBGE. IBGE - Cidades. Disponível em: <https://cidades.ibge.gov.br/>. Acesso em: 15 dez 2018.

[27] LEITE, José Rubens Morato (org.). Manual de direito ambiental. São Paulo: Saraiva, 2015.

[28] MARCONI, M. A.; LAKATOS, E. M. Fundamentos de metodologia científica. São Paulo: Editora Atlas, 2010.

[29] MARTINS, Et al. Impactos da construção da usina hidroelétrica de sobradinho no regime de vazões no baixo São Francisco. Revista Brasileira de Engenharia Agrícola e Ambiental. Campina Grande, v.15, no 9, p. 1054-1061. 2011.

[30] MELO, J. S. Dinâmica geomorfológica do ambiente de encosta em Brejo da Madre de Deus - PE: uma abordagem a partir da perspectiva morfoestratigráfica aplicada aos depósitos coluviais. Recife, 2008. 125 folhas. Dissertação (Mestrado) - Universidade Federal de Pernambuco. CFCH. Geografia, 2008.

[31] MEDEIROS, P.R.P., KNOPPERS, B.A., SANTOS JÚNIOR, R. C., SOUZA, W.F.L. Aporte Fluvial e Dispersão de Matéria Particulada em Suspensão na zona costeira do rio São Francisco (SE/AL). Revista Geochimica Brasiliensis, v. 21, p. $212-231,2007$.

[32] MINAYO, Maria Cecília de Souza (org.). Pesquisa Social. Teoria, método e criatividade. 18 ed. Petrópolis: Vozes, 2001.

[33] MINISTÉRIO DA PESCA E AQUICULTURA - Boletim estatístico da Pesca e Aquicultura - Brasil 2008-2009. 2009

[34] MINISTÉRIO DOS TRANSPORTES - Plano Hidroviário Estratégico - Brasil 2013.

[35] PINTO, Josefa Eliane Santana de S. \& AGUIAR NETTO, Antenor de Oliveira. Clima, Geografia e Agrometereologia: uma abordagem interdisciplinar. Edufs: Aracaju, 2008

[36] PNUD. ATLAS BRASIL 2013. Atlas de Desenvolvimento Humano do Brasil 2013. Programa das Nações Unidas Para $\quad 0 \quad$ Desenvolvimento. Disponível em: <http://www.pnud.org.br/IDH/Atlas2013.aspx?indiceAccordion=1\&li=li_Atlas2013>. Acesso em 31 nov 2018.

[37] SANTANA, Neuma Rúbia Figueiredo. Hidrodinâmica ambiental no baixo São Francisco e suas relações antrópicas. 2017. Tese (Doutorado em Desenvolvimento e Meio Ambiente) - Universidade Federal de Sergipe. Orientador: Antenor de Oliveira Aguiar Netto.

[38] SANTOS, Riclaudio Silva. Análise integrada da paisagem do geocomplexo Alto Sertão sergipano. 2018. Dissertação (Mestrado em Geografia) - Universidade Federal de Sergipe. Orientador: Josefa Eliane Santana de Siqueira Pinto.

[39] SELLING JUNIOR, Theodor. A Bahia e seus veleiros: uma tradição que desapareceu. Serviço de Documentação Geral da Marinha. Rio de Janeiro, 1976.

[40] SONG, X. J. et al. 2007. Ecological and environmental instream flow requirements for the Wei River - the largest tributary of the Yellow River. Hydrological Processes., 21,1066-1073.

[41] STEVANUX, J. C.; Martins, D. P. e Meurer, M. 2009. Changes in a large regulated tropical river: The Paraná River downstream from the Porto Primavera Dam, Brazil. Geomorphology., 113, 230-238.

[42] SYVITSKI, J. P. M. et al. 2005. Impact of Humans on the Flux of Terrestrial Sediment to the Global Coastal Ocean. Science., 308, 376-380.

[43] VASCO, Anderson Nascimento do. Indicadores de alteração hidrológica: O declínio das vazões no baixo rio São Francisco. 2015. Tese (Doutorado em Desenvolvimento e Meio Ambiente) - Universidade Federal de Sergipe. Orientador: Antenor de Oliveira Aguiar Netto.

[44] ZAHAR, Y.; Ghorbel, A. e Albergel, J. 2008. Impacts of large dams on downstream flow conditions of rivers: Aggradation and reduction of the Medjerda channel capacity ownstream of the Sidi Salem dam (Tunisia). Journal of Hydrology., 351, 318-330.

[45] ZAPPI, D. Fitofisionomia da caatinga associada à cadeia do Espinhaço. Revista Megadiversidade, v. 4, no1-2, p. 3438, dezembro 2008. 


\section{Capítulo 6}

Avaliação da qualidade da água do rio paripe, indiarobase, com emprego de indicadores quantitativos

\section{Carlos Alexandre Borges Garcia}

Cristina dos Santos Esteves

Marinoé Gonzaga da Silva

José Augusto Oliveira Junior

Silvânio Silvério Lopes da Costa

Resumo: Os rios do Nordeste sofrem fortemente com a antropização, redução de mata ciliar, manejo inadequado dos solos, eutrofização, além da influência espacial e sazonal, bem característica da região. 0 rio Paripe, um dos principais afluentes do rio Real, de suma importância para abastecimento público no município de Indiaroba - Sergipe Brasil, convive com a realidade de impactos ambientais nas suas margens, e essa previsibilidade de melhorias não é notória devido a intensidade do impacto sofrido e a escassez de medidas favoráveis para a mudança desse paradigma. 0 monitoramento foi realizado durante os períodos chuvoso e seco dos anos 2013, 2014, 2016 e 2017. As variáveis estudadas foram demanda bioquímica de oxigênio (DBO), oxigênio dissolvido (OD), coliformes totais (Col-T), fósforo total (PT), sólidos totais dissolvidos (STD), clorofila-A (Cl-A), nitrogênio total (NT), potencial hidrogeniônico ( $\mathrm{pH})$, temperatura (T) e a turbidez (Tur). A verificação da qualidade da água por meio de parâmetros préestabelecidos foi útil quando avaliados e correlacionados ao manejo e diferentes usos e ocupação do solo.

Palavras-chave: Degradação Hídrica, Bacia hidrográfica, Manejo. 


\section{INTRODUÇÃO}

Ambientes aquáticos têm sido constantemente avaliados, sendo sua disponibilidade cada vez menor e com impactos antrópicos que podem ocasionar catástrofes ambientais, influenciando na redução da quantidade e principalmente qualidade da água. As atividades são inúmeras, mas as que tem gerado mais enfoque são o crescimento populacional, a produção excessiva de resíduos sólidos, o crescimento industrial, e o despejo de efluentes in natura em corpos hídricos, causando efeitos negativos na disponibilidade hídrica (MARTINS 2010). Aproximadamente 2,5\% do volume total de água existente no mundo (34,65 milhões de km3), estão classificados como água doce, estando assim distribuída: 68,9\% calotas polares e geleiras, $29,9 \%$ água subterrânea, $0,3 \%$ rios e lagos, e $0,9 \%$ outros reservatórios (SHIKLOMANOV, 1998; REBOUÇAS, 2006). Sendo assim é importante a proteção e prevenção dos recursos hídricos contra atividades que possam causar a sua degradação (TUNDISI, 2003).

No Brasil, a falta de planejamento e gestão desse recurso natural, acarretará, em pouco tempo, uma catástrofe ambiental previsível, com o aumento gradativo da escassez de água disponível a baixo custo (Reis 2004). Embora o Brasil possua expressivo potencial hídrico, é importante sublinhar a significativa variabilidade temporal e espacial das águas em suas diversas regiões, estreitamente associada à variação das precipitações e à sua sazonalidade, dentre outras características naturais (AGUIAR et al 2013). Desse modo, práticas de ações mitigadoras dos impactos ambientais ocasionados pelas atividades antrópicas são e serão determinantes para a disponibilidade hídrica.

As atividades humanas têm elevado o consumo hídrico, pode-se destacar o abastecimento humano, a agricultura/pecuária e setores industriais. A agricultura é responsável pela maior percentagem em relação a quantidade bruta utilizada, com pouquíssima eficiência em seus sistemas de irrigação, entretanto, a demanda pode se tornar ainda maior a depender da eficiência do manejo da irrigação e do solo. Contudo, há a possibilidade que essa água retorne ao ciclo hidrológico. De acordo com dados do Organização das Nações Unidas para Agricultura e Alimentação (FAO, Food and Agriculture Organization), estima-se que, mundialmente, o uso da água proveniente das diversas fontes está assim dividido: Agricultura (70-80\%), indústrias (20-25\%) e consumo doméstico (6-10\%) (FAO, 2003).

Dentre esses usos exige-se uma organização e eficiência maior na governança relacionada a uso e demanda por conta de conflitos, principalmente, a questão da prioridade hídrica. Geralmente a capacidade de autodepuração, dos rios, não são estudadas, sendo que estudos prévios contribuem para o restabelecimento do equilíbrio no meio aquático, ou seja, a busca pelo estágio inicial encontrado antes do lançamento de efluentes sendo realizada por mecanismos essencialmente naturais (SPERLING, 1996).

Essa capacidade sendo estudada e estabelecida como norma para lançamento seria útil para baratear custos de tratamento de água para abastecimento, uma vez que a baixa qualidade da água onera os custos do tratamento. 0 barateamento aconteceria na medida que o rio se reestabelecesse naturalmente a sua qualidade anterior ao lançamento. Apesar que, segundo o conselho nacional do meio ambiente (CONAMA), através da resolução $\mathrm{n}^{\circ} 357 / 2005$, o dejeto aplicado não pode influenciar na mudança do enquadramento classificatório do rio.

Segundo a resolução do CONAMA no 430/2011, os efluentes não poderão conferir ao corpo receptor características de qualidade em desacordo com as metas obrigatórias progressivas, intermediárias e final, do seu enquadramento (CONAMA,2011). Entretanto a necessidade de fiscalização da entrada dos efluentes nos mananciais torna-se essencial, na medida que estudos poderão demonstrar a devida qualidade das águas destinadas a abastecimento e, utilizar para conhecimento dos órgãos fiscalizadores a respeito da aplicação da Resolução que dispõe normas para lançamentos.

Os rios do Nordeste sofrem fortemente com a antropização, redução de mata ciliar, assoreamento, redução de fluxo, lançamento de efluentes domésticos e industriais, descarte inadequado de resíduos sólidos, manejo inadequado dos solos, eutrofização, além da influência espacial e sazonal, bem característica da região (NETO et al. 2010).

Segundo Rebouças (2006), a qualidade da água dos mananciais utilizados é degradada pelo lançamento deliberado ou tolerado - de esgotos domésticos e industriais não tratados, uso e ocupação inadequada do meio físico e outros fatores impactantes supracitados. A realidade de Sergipe não difere muito destas características predominantes nas bacias hidrográficas. Sofre muita influência dos perímetros irrigados e dos impactos gerados em decorrência disso. Segundo Aguiar et al (2013) as bacias hidrográficas de Sergipe, exceto a bacia do rio São Francisco, sofrerão um déficit de suprimento de demanda, onde em 2020 não terão capacidade hídrica para abastecimento humano. 
A bacia hidrográfica do rio Paripe, um dos principais afluentes do rio Real, de suma importância para abastecimento público no município de Indiaroba convive com impactos ambientais citados anteriormente, e essa previsibilidade é notória devido ao impacto sofrido e a escassez de medidas favoráveis para a mudança desse paradigma. Este trabalho tem como objetivo avaliar a qualidade da água do rio Paripe através de parâmetros químicos, físicos e biológicos da qualidade da água do rio Paripe, Indiaroba, Sergipe, através da análise multivariada e índices de qualidade da água e índice de estado trófico.

\section{MATERIAIS E MÉTODOS}

\section{1. ÁREA DE ESTUDO}

0 estudo foi realizado na bacia hidrográfica do rio Real onde apresenta grande importância para o sul sergipano, principalmente por possibilitar atividades como produção agrícola, abastecimento público e industrial, atividade pesqueira e de lazer (SEMARH-SE). Contudo, além do elevado nível de exploração, uma série de transformações na sua dinâmica possibilitam alterações ecossistêmicas e socioeconômicas na região, que comprometem a qualidade da água e consequentemente o abastecimento e a saúde pública

0 rio Paripe um dos principais afluentes do rio Real, está localizado na região Sul do Estado de Sergipe, Figura 1, tendo sua nascente localizada no município de Umbaúba estendendo-se pelas terras do município de Indiaroba (SEMARH-SE). A sub-bacia hidrográfica está inserida no bioma Mata Atlântica, mas atualmente, a vegetação nativa predominante se restringe aos manguezais nos estuários, vegetação de restinga e alguns remanescentes da Floresta Tropical Úmida (SEMARH-SE).

Na avaliação da qualidade da água do rio Paripe, o trecho do afluente, totalizando 4,8 km de extensão com distância entre pontos de $1 \mathrm{~km}$ em média. Tem sua nascente no município de Umbaúba, percorrendo suas terras e a seção de monitoramento tem-se início nas terras de Indiaroba, em direção a jusante. 0 critério adotado para se eleger os pontos de monitoramento foi a existência de áreas rurais e aglomerados urbanos próximo as margens do rio em estudo.

Durante as coletas utilizou-se frascos de PVC, com volume aproximado de $100 \mathrm{~mL}$ de água, a qual foi transferida para garrafas plásticas e as amostras armazenadas em caixa de isopor, a uma temperatura média de $4 \stackrel{\text { o}}{ } \mathrm{C}$ e conduzidas ao laboratório de química analítica ambiental (LQA) na Universidade Federal de Sergipe (UFS).

Figura 1. Localização do Rio Paripe no Estado de Sergipe.

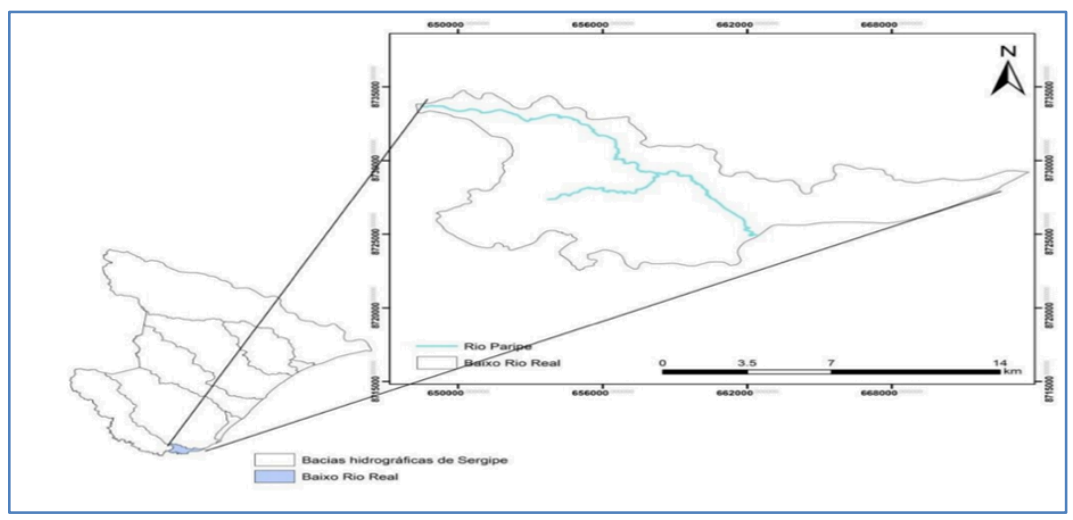

Fonte: Arquivo Pessoal 


\subsection{ETAPAS DO MONITORAMENTO}

O monitoramento foi realizado durante os períodos chuvoso e seco dos anos 2013, 2014, 2016 e 2017 em quatro estações ao longo do rio Paripe. Sendo que o as três primeiras estações foram realizadas coletas abrangendo período sazonal (seco e chuvoso). Já o quarto ponto as coletas sazonais foram realizadas pela Secretaria Estadual de Meio Ambiente e Recursos Hídricos (SEMARH-SE) que contribuiu com a base de dados usada nesta pesquisa. A disposição das estações de coleta foram escolhidas para obter um melhor efeito espacial e o período de coleta compreendeu e deu prioridade a sazonalidade sobre as características físicas, químicas e biológicas da água do rio. As coordenadas dos pontos citados estão mostradas na Tabela 1.

Tabela 1. Coordenadas dos pontos de coleta de água no rio Paripe.

\begin{tabular}{llll}
\hline Estações & \multicolumn{2}{c}{ Coordenadas } & \multicolumn{1}{c}{ Características Local } \\
& Latitude & Longitude & \\
\hline P1 & $11^{\circ} 49^{\prime} 24^{\prime \prime}$ S & $37^{\circ} 54^{\prime} 85^{\prime \prime} \mathrm{W}$ & Pastagem degradada, vestígios de mata ciliar. \\
\hline P2 & $11^{\circ} 49^{\prime} 88^{\prime \prime} \mathrm{S}$ & $37^{\circ} 53^{\prime} 37^{\prime \prime} \mathrm{W}$ & Extração de areia de rio, pastagens. \\
\hline P3 & $11^{\circ} 51^{\prime} 69^{\prime \prime} \mathrm{S}$ & $37^{\circ} 52^{\prime} 01^{\prime \prime} \mathrm{W}$ & Pastagem degrada, sem mata ciliar \\
\hline P4 & $11^{\circ} 50^{\prime} 64^{\prime \prime} \mathrm{S}$ & $37^{\circ} 52^{\prime} 86^{\prime \prime} \mathrm{W}$ & Extração de areia, influência da tábua de Maré \\
\hline
\end{tabular}

Fonte: Arquivo Pessoal

As variáveis estudadas foram demanda bioquímica de oxigênio (DBO), oxigênio dissolvido (OD), coliformes totais (ColT), fósforo total (PT), sólidos totais dissolvidos (STD), clorofila-a (CL-A), nitrogênio total (NT), potencial hidrogeniônico $(\mathrm{pH})$, temperatura (T) e a turbidez (Tur). As metodologias de referência usada para verificação estão descritas na Tabela 2.

Tabela 2. Variáveis, métodos e referências utilizados nas quantificações.

\begin{tabular}{|c|c|c|}
\hline Variável & Metodologia & Referência \\
\hline Tur(uT) & Turbidímetro & SMEWW,2012,2130B \\
\hline STD (mg.L-1) & In loco & SONDA HANNA \\
\hline ColT (NMP/100 mL) & Colimetria & APHA,9221B \\
\hline OD (mg.L-1 0) & In loco & SONDA HANNA \\
\hline DBO (mg.L-102) & Respirométrico & SMEWW,2012,5210-D \\
\hline PT (mg.L-1) & Espectrofotômetro & APHA 4500-P E \\
\hline NT(mg.L-1) & Espectrofotômetro & APHA 4500-P E \\
\hline $\mathrm{T}\left({ }^{\circ} \mathrm{C}\right)$ & In loco & SONDA HANNA \\
\hline pH & Peagâmetro & APHA, $4500 \mathrm{H}+\mathrm{B}$ \\
\hline
\end{tabular}

Legenda: Sólidos Totais Dissolvidos (STD), Potencial de Hidrogênio (pH), Coliformes Totais (ColT), Oxigênio Dissolvido (OD), Demanda Bioquímica de Oxigênio (DBO), Fosforo Total (PT), Nitrogênio Total (NT), Clorofila-A (CLA), Turbidez (Tur), Temperatura (T).

Os pontos foram escolhidos de acordo com a característica local e sua possível interferência na qualidade dos recursos hídricos, Figura 2. 
Figura 2. Disposição dos pontos de Amostragem e identificação do uso e ocupação do solo.

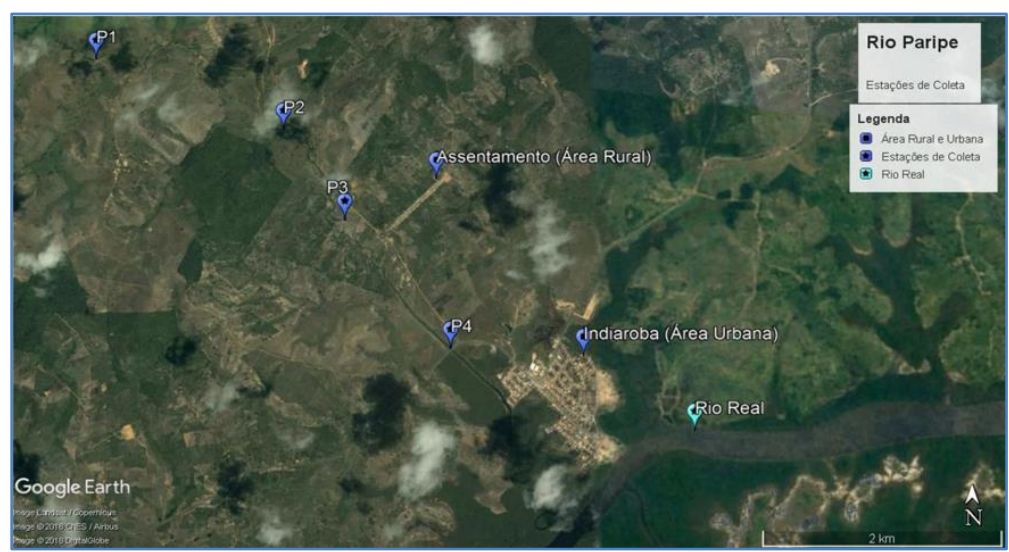

Fonte: Google Earth.

\section{RESULTADOS E DISCUSSÃO}

A Tabela 3 apresenta os resultados dos parâmetros analisados e valores de média, desvio padrão e coeficiente de variação dos dados físico-químicos e biológicos por ponto de coleta e períodos sazonais.

Tabela 3. Estatística descritiva dos parâmetros da coluna d'água do Rio Real $(\mathrm{n}=2)$

\begin{tabular}{|c|c|c|c|c|c|c|c|c|c|c|}
\hline \multicolumn{11}{|c|}{ Período Seco (S1) } \\
\hline Estações/Ano & PH3 & DBO4 & T5 & TUR6 & STD7 & PT8 & NT9 & ColT10 & OD11 & CL-A12 \\
\hline P1/14 & 6,8 & 8,7 & 26 & 1,5 & 101 & 0,03 & 0,56 & 930 & 6,7 & 4,8 \\
\hline P1/16 & 6,9 & 5,8 & 25,4 & 8,5 & 113 & 0,04 & 0,38 & 120 & 4,4 & NA \\
\hline Média & 6,85 & 7,25 & 25,7 & 5 & 107 & 0,035 & 0,47 & 525 & 5,55 & 4,8 \\
\hline DP13 & 0,07 & 2,05 & 0,42 & 4,95 & 8,49 & 0,01 & 0,13 & 572,76 & 1,63 & 0 \\
\hline C.V14(\%) & 1,03 & 28,28 & 1,65 & 98,99 & 7,93 & 20,20 & 27,08 & 109,10 & 29,30 & 0 \\
\hline P2/14 & 7 & 9,1 & 24 & 14 & 110 & 0,03 & 0,11 & 2100 & 8,5 & 2,55 \\
\hline P2/16 & 7,3 & 21,3 & 27 & 10,2 & 112 & 0,05 & 0,34 & 1200 & 4,3 & NA \\
\hline Média & 7,15 & 15,2 & 25,5 & 12,1 & 111 & 0,04 & 0,225 & 1650 & 6,4 & 2,55 \\
\hline DP & 0,21 & 8,63 & 2,12 & 2,69 & 1,41 & 0,01 & 0,16 & 636,40 & 2,97 & 0 \\
\hline C.V(\%) & 2,97 & 56,75 & 8,32 & 22,21 & 1,27 & 35,36 & 72,28 & 38,57 & 46,40 & 0 \\
\hline P3/14 & 6,8 & 15,6 & 28 & 14 & 116 & 0,04 & 0,11 & 39 & 9 & 5,4 \\
\hline P3/16 & 7,2 & 6,9 & 28,5 & 11,6 & 210 & 0,04 & 0,36 & 60 & 5,8 & NA \\
\hline Média & 7 & 11,25 & 28,25 & 12,8 & 163 & 0,04 & 0,235 & 49,5 & 7,4 & 5,4 \\
\hline DP & 0,28 & 6,15 & 0,35 & 1,70 & 66,47 & 0,00 & 0,18 & 14,85 & 2,26 & 0 \\
\hline C.V(\%) & 4,04 & 54,68 & 1,25 & 13,26 & 40,78 & 0,00 & 75,22 & 30,00 & 30,58 & 0 \\
\hline P4/13 & 7,8 & 10,9 & 25 & 80,8 & 268,2 & 0,03 & 0,13 & 1700 & 5,6 & 1,3 \\
\hline P4/14 & 7,6 & 1,9 & 26 & 8,9 & 114 & 0,01 & NA & 610 & 7,2 & 2,6 \\
\hline Média & 7,7 & 6,4 & 25,5 & 44,9 & 191,1 & 0,0 & 0,1 & 1155,0 & 6,4 & 2,0 \\
\hline DP & 0,1 & 6,4 & 0,7 & 50,8 & 109,0 & 0,0 & 0,0 & 770,7 & 1,1 & 0 \\
\hline C.V(\%) & 1,84 & 99,44 & 2,77 & 113,36 & 57,06 & 70,71 & 0,00 & 66,73 & 17,68 & 0,00 \\
\hline
\end{tabular}


Tabela 3. Estatística descritiva dos parâmetros da coluna d'água do Rio Real $(\mathrm{n}=2)$

\begin{tabular}{|c|c|c|c|c|c|c|c|c|c|c|}
\hline \multicolumn{11}{|c|}{ Período Chuvoso (C2) } \\
\hline P1/14 & 6,70 & 3,2 & 26 & 1,5 & 104 & 0,02 & 0,56 & 5400 & 6,7 & 4,1 \\
\hline P1/17 & 6,5 & 6,7 & 28 & 26 & 125 & 0,05 & 0,47 & 250 & 8,2 & NA \\
\hline Média & 6,60 & 4,95 & 27,00 & 13,75 & 114,50 & 0,04 & 0,52 & 2825,00 & 7,45 & 4,10 \\
\hline DP & 0,14 & 2,47 & 1,41 & 17,32 & 14,85 & 0,02 & 0,06 & 3641,60 & 1,06 & 0 \\
\hline C.V(\%) & 2,14 & 50,00 & 5,24 & 126 & 12,97 & 60,61 & 12,36 & 128,91 & 14,24 & 0 \\
\hline P2/14 & 6,5 & 8,2 & 24 & 44 & 154,8 & 0,03 & 0,11 & 1600 & 8,4 & 47,5 \\
\hline P2/17 & 6,3 & 32,7 & 28 & 86 & 123 & 0,06 & 0,5 & 2400 & 7,9 & NA \\
\hline Média & 6,40 & 20,45 & 26,00 & 65,00 & 138,90 & 0,05 & 0,31 & 2000 & 8,15 & 47,50 \\
\hline DP & 0,14 & 17,32 & 2,83 & 29,70 & 22,49 & 0,02 & 0,28 & 565,69 & 0,35 & 0,00 \\
\hline C.V(\%) & 2,21 & 84,71 & 10,88 & 45,69 & 16,19 & 47,14 & 90,42 & 28,28 & 4,34 & 0,00 \\
\hline P3/14 & 6,8 & 9,8 & 28 & 14,7 & 102 & 0,02 & 0,11 & 350 & 8,9 & 22,2 \\
\hline P3/17 & 6,7 & 7,8 & 28,5 & 70 & 300 & 0,06 & 0,41 & 350 & 8,3 & NA \\
\hline Média & 6,75 & 8,8 & 28,25 & 42,35 & 201 & 0,04 & 0,26 & 350 & 8,6 & 22,2 \\
\hline DP & 0,07 & 1,41 & 0,35 & 39,10 & 140,01 & 0,03 & 0,21 & 0,00 & 0,42 & 0,00 \\
\hline C.V(\%) & 1,05 & 16,07 & 1,25 & 92,33 & 69,66 & 70,71 & 81,59 & 0,00 & 4,93 & 0,00 \\
\hline P4/13 & 7,35 & 7 & 25 & 12,5 & 112 & 0,05 & 0,43 & 1100 & 7,4 & 1,3 \\
\hline P4/14 & 7,3 & 0,2 & 23 & 9 & 100 & 0,05 & NA & 1000 & 7,6 & 0,052 \\
\hline Média & 7,33 & 3,60 & 24,00 & 10,75 & 106,00 & 0,05 & 0,43 & 1050 & 7,50 & 0,68 \\
\hline DP & 0,04 & 4,81 & 1,41 & 2,47 & 8,49 & 0,00 & 0,00 & 70,7 & 0,14 & 0,88 \\
\hline C.V(\%) & 0,48 & 133,56 & 5,89 & 23,02 & 8,00 & 0,00 & 0,00 & 6,7 & 1,89 & 130,54 \\
\hline
\end{tabular}

Legenda: 1-Seco, 2-Chuvoso, 3-Potencial de Hidrogênio (pH), 4-Demanda Bioquímica de Oxigênio (DBO),

5-Temperatura $\left(\mathrm{T}^{\circ} \mathrm{C}\right), 6$-Turbidez (Tur), 7-Sólidos Totais Dissolvidos (STD), 8-Fósforo Total (PT), 9-

Nitrogênio Total (NT), 10-Coliformes Totais (ColT), 11-Oxigênio Dissolvido (OD), 12-Clorofila-A (CL-A), 13-Desvio Padrão, 14-Coeficiente de Variação.

\subsection{PARÂMETROS DE QUALIDADE DA ÁGUA}

Os parâmetros $\mathrm{pH}, \mathrm{OD}, \mathrm{STD}, \mathrm{TUR}, \mathrm{T}^{\circ} \mathrm{C}, \mathrm{DBO}, \mathrm{NT}, \mathrm{CT}$, CLA e PT, foram determinados para as amostras de água coletadas no Rio Paripe, Indiaroba, Sergipe, nos períodos seco e chuvoso. De acordo com a Tabela 3 a temperatura da água variou entre $24{ }^{\circ} \mathrm{C}$ e $28,5^{\circ} \mathrm{C}$ no período seco e de $23^{\circ} \mathrm{C}$ e $28,5^{\circ} \mathrm{C}$ no período chuvoso; o OD variou de 4,3 mg L-1 a $9 \mathrm{mg} \mathrm{L}-1$ durante o período seco, e de 6,7 mg L-1 a 8,9 mg L-1 no período chuvoso; o NT variou de $0,11 \mathrm{mg} \mathrm{L}-1$ a $0,56 \mathrm{mg} \mathrm{L}-1$ no período seco e no período chuvoso de $0,11 \mathrm{mg} \mathrm{L}-1$ a 0,56 mg L-1; o PT variou de 0,03 mg L-1 a 0,05 mg L-1 no período seco e de 0,02 mg L-1 a 0,06 mg L-1 no período chuvoso.

A DBO variou de 1,9 a $21,3 \mathrm{mg} 02 \mathrm{~L}-1$ no período seco e de 0,2 a $32,7 \mathrm{mg} 02 \mathrm{~L}-1$ no período chuvoso; o pH variou de 6,8 a 7,8 no período seco e de 6,3 a 7,3 no período chuvoso; o CT variou de 39 a 2100 NPM/100mL, no período seco e de 250 a $5400 \mathrm{NPM} / 100 \mathrm{~mL}$, no período chuvoso; a CL-A variou de 1,3 a 5,4 ug.L-1, no período seco de 0,05 a 47,5 ug.L-1, no período chuvoso; o STD variou de $101 \mathrm{mg} \mathrm{L-1} \mathrm{a} \mathrm{268,2}$ mg L-1 no período seco e de $100 \mathrm{mg}$ L-1 a $300 \mathrm{mg}$ L-1 no período chuvoso; e a TUR. variou de 1,5 a 80 UNT no período seco e de 1,5 UNT a 86 UNT no período chuvoso. A variação do parâmetro pH por pontos de amostragens e sazonalidade está descrito no Figura 3.

Nos ecossistemas aquáticos o $\mathrm{pH}$ é um parâmetro fundamental, entretanto, o grande número de fatores que o influenciam tornam sua interpretação difícil (ESTEVES, 2011). Apenas no ponto 3 no período seco, o coeficiente de variação (CV\% $=4$ ) apresentou significância, os demais não demostraram diferença 
significativa entre pontos e período sazonal. Todas as amostras estiveram dentro do limite estabelecido pela Resolução CONAMA n 357/2005, com pH entre 6,0 a 9,0 para as classes 1 e 2 de água doce.

As medidas de $\mathrm{pH}$ são importantes para o fornecimento de informações a respeito da qualidade da água. Os organismos aquáticos estão, geralmente, adaptados às condições próximas a neutralidade e, em consequência, alterações bruscas do $\mathrm{pH}$ da água podem ocasionar o desaparecimento dos seres aquáticos (ZUMACH 2003). 0 pH da água é controlado pelo equilíbrio na concentração de compostos dissolvidos. Por exemplo, em águas naturais, esse equilíbrio depende da presença de íons carbonatos, dióxido de carbono (CO2), ácido carbônico (H2CO3), carbonatos (CO3-2) e bicarbonatos (HCO3-) (EPA, 2010) e de outros componentes naturais, como os ácidos húmicos e fúlvicos, resultantes da degradação da matéria orgânica (HERMES et al., 2006). Outro parâmetro avaliado, e importante em estudos de qualidade de água é a demanda bioquímica de oxigênio (DBO). Valores observados por pontos de amostragem e sazonalidade estão demostrados na Figura 4.

Figura 3. Variação do parâmetro pH nos pontos de amostragem.

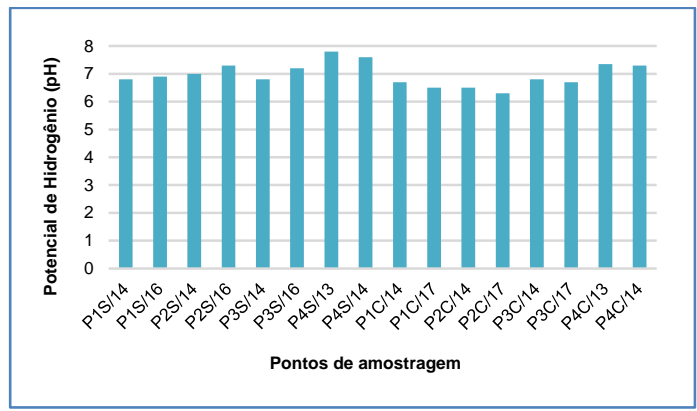

Legenda: P- pontos de amostragem, S- período seco, C- período chuvoso

Figura 4. Variação do parâmetro demanda bioquímica de oxigênio (DBO) nos pontos de amostragem.

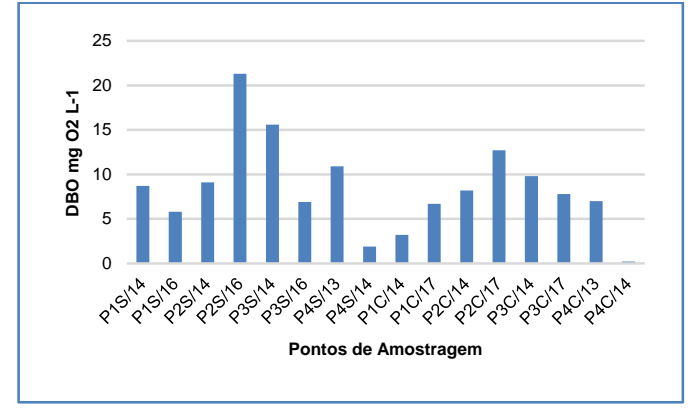

Os valores para coeficiente de variação do ponto $4(C V \%=99,4)$ no período seco e (CV\% $=133,53)$ no período chuvoso, percebe-se um aumento da variação no período chuvoso em relação ao seco. Isso ocorre devido ao carreamento de matéria orgânica para o leito do rio. Os valores da DBO são influenciados diretamente ao grau de poluição produzida por matéria orgânica oxidável biologicamente, que corresponde à quantidade de oxigênio que é consumida pelos microrganismos do esgoto ou águas poluídas, na oxidação biológica, quando mantida a uma dada temperatura por um intervalo de tempo convencionado (LIMA, 2001; FARIAS, 2006).

0 ponto 2 e 3 estão localizados numa área de exploração de areia contribuindo para elevação nos valores da DBO do rio Paripe. Essa elevação pode ser provocada pelo aumento da calha do rio e consequentemente acúmulo de material orgânico depositado no fundo, formando uma espécie de lodo de fundo, rico em matéria orgânica. A retirada de areia acontece com maior frequência durante o período seco devido à maior demanda, onde se percebe um aumento nos valores de DBO, Figura 4, nos pontos 2/2016 e 3/2014 no período seco, com valores de DBO =21,3 e DBO $=15,3$, respectivamente.

A deposição de matéria orgânica também pode ser uma indicação do incremento da microflora presente provocando um desequilíbrio no ecossistema aquático (SPERLING 1996). Altos teores de matéria orgânica 
causam a extinção do oxigênio existente na água, provocando a morte de peixes e outras espécies e o crescimento exagerado da microflora, além de produzir sabores e odores desagradáveis. (CETESB, 2017). A presença de matéria orgânica em grande quantidade resulta numa camada de lodo, da ordem de alguns milímetros de espessura consome o oxigênio da massa líquida sobrenadante. Outro fator que pode resultar no consumo de oxigênio é a reintrodução na massa líquida exercendo uma demanda líquida de oxigênio chamada de demanda bentônica ou demanda de oxigênio pelo sedimento (Sperling, 1996). Os resultados encontrados não estão de acordo com a Resolução 357/2005 do CONAMA, para as águas doces classe 2 , até $5 \mathrm{mg} \mathrm{L}-1$ de 02 , exceto nos pontos $\mathrm{P} 4 / 2014$ (DBO $=1,9$ ) no período seco e no P4/2014 (DBO $=0,2$ ) no período chuvoso.

A temperatura também exerce grande influência quando relacionada a outros parâmetros, e sua elevação ou diminuição de forma brusca pode provocar desequilíbrio e risco a sobrevivência de seres que dependem diretamente da água para sobreviver (JIAN et al 2003). Os valores de temperatura observados por pontos de amostragem e por sazonalidade estão descritos na Figura 5.

0 parâmetro temperatura não demostrou variação significativa nos pontos de amostragem variando de 24,0 a $28,5^{\circ} \mathrm{C}$. Os pontos com maior temperatura são aqueles em que não foi observado mata ciliar, P3 e P4, em que há substituição da mata ciliar por gramíneas com fins para alimentação animal. A falta de vegetação ciliar é um dos principais motivos para elevação da temperatura, sendo assim, a manutenção da vegetação ciliar é a maneira mais efetiva de prevenir aumentos da temperatura da água, conforme relatado em vários estudos (SWIFT e MESSER, 1971; (CORBETT e SPENCER, 1975); (SUGIMOTO et al., 1997); (ARCOVA e CICCO, 1999).

A falta de arborização nas margens dos corpos aquáticos traz diversas consequências, além do incremento na temperatura da água ocorre também o carreamento de partículas que em suspensão afeta a entrada de luz solar no perfil d'água, dificultando gradientes de incidência luminosa e disponibilidade de nutrientes observados em ecossistemas aquáticos tropicais podem afetar de formas variadas as relações tróficas nestes ambientes, e em diferentes escalas (RIVERA 2003).

Em relação a turbidez foi observada uma alta variação para o período seco e no período chuvoso, com CV\% variando de 13,26 - 113,36 e de 23,02 - 126, respectivamente, observe-se então que a antropia está deteriorando a qualidade da água, devido a redução da vegetação das margens e sendo agravado no período chuvoso com o aumento da pluviosidade.

Na Figura 6 se observa os valores de turbidez por pontos de amostragem e por sazonalidade.

Figura 5. Variação do parâmetro Temperatura (T) nos pontos de amostragem.

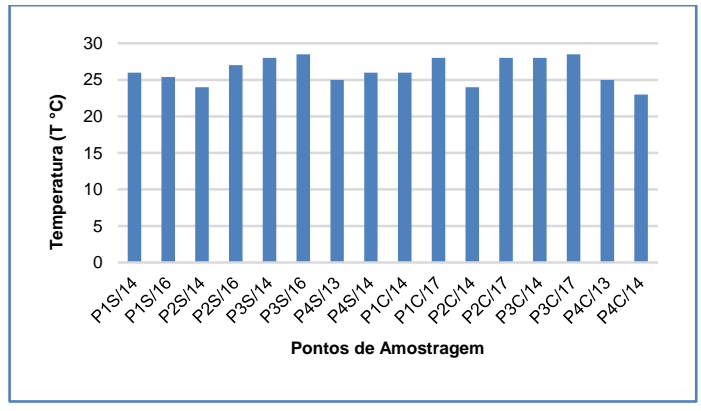

Figura 6. Variação do parâmetro Turbidez nos pontos de amostragem.

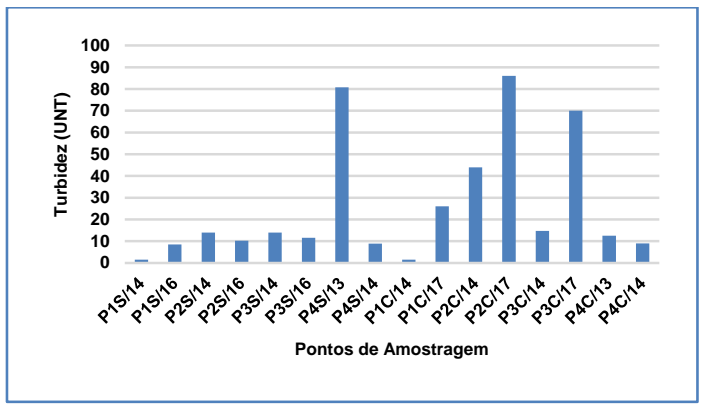


Silveira et al (2015) estudaram os parâmetros físicos, químicos e microbiológicos que interferem na qualidade das águas da bacia hidrográfica do rio Sergipe, os resultados mostraram altos valores de concentração para turbidez, cor aparente, $\mathrm{pH}$, oxigênio dissolvido, condutividade, clorofila-a, fósforo total, nitrogênio total, TOC, DBO, DQO, coliformes e Fe, todos acima dos valores máximos permitidos pela resolução CONAMA no: 357/2005 para rios de classe 1 e 2, destinados para o consumo humano.

Já os valores de turbidez, encontrados para o rio Paripe, mantiveram-se dentro dos limites da Resolução ${ }^{\circ}$ $357 / 2005$ do CONAMA para classe 2 (100 UNT). Os pontos que se mostraram elevados em ambos os períodos seco e chuvoso foram respectivamente P4/2013 (80 UNT) e P2/2017 (86 UNT), P3/2017 (70 UNT), que podem estar sendo influenciados pela extração de areia do rio, além do escoamento superficial que contribui para o desequilíbrio. 0 impacto da extração e o escoamento superficial, somados, aumentam os índices no período chuvoso, Figura 6.

Segundo Nogueira (2016), o aumento da concentração de partículas em suspensão no curso d'água, é causado pelo revolvimento e desagregação do material mineral no curso d'água, durante o processo de extração de areia. Além disso, destacam-se as operações de lavra, que podem causar um impacto direto nos parâmetros físicos da corrente fluvial, tais como geometria do canal, elevação do leito, composição e estabilidade do substrato, velocidade, turbidez, transporte de sedimentos, vazão e temperatura (Rundquist 1980, Pauley et al. 1989).

Um outro parâmetro importante na avaliação da qualidade da água são os sólidos totais dissolvidos (STD), onde sua presença na água tende a aumentar os índices de condutividade e turbidez. Na Figura 7, estão descritos os valores observados por pontos de amostragem e por sazonalidade para STD.

Em águas continentais, os sólidos totais dissolvidos variam em relação à hidrogeoquímica regional e das drenagens de rochas ígneas ou sedimentares (Tundisi e Matsumura Tundisi, 2008). Os teores médios de STD obtidos no presente estudo foram menores que $500 \mathrm{mg} \mathrm{L}-1$, padrão de qualidade descrito na resolução CONAMA 357 para águas doces classe I, II e III (CONAMA, 2005).

Em um estudo de Barreto et al. (2014), foram medidos os teores de sólidos totais dissolvidos e avaliada a relação entre a vazão e a qualidade da água numa seção do Rio Catolé Grande-BA, onde se observou um aumento dos sólidos totais dissolvidos ao aumentar a vazão do rio, neste estudo podemos relacionar o aumento dos níveis ao período chuvoso que variou de 100 a 300 (mg L-1). Em relação ao período seco, sugere-se que à antropia pode ser causada pela extração de areia, com variação de 101 a 268,2 mg L-1, não demostrando diferença significativa na avaliação sazonal. Os pontos que se mostraram elevados nos períodos seco e chuvoso foram respectivamente P3S/2016 (210 mg L-1), P4S/2013 (268,2 mg L-1) e P3C/2017 (300 mg L-1), que representam locais com extração de areia no leito do rio.

Para o parâmetro fósforo total (PT), Figura 8, os valores estiveram de acordo com o limite para este parâmetro estabelecido na Resolução 357 do CONAMA para águas doces classe 2, até 0,1 mg L-1.

Figura 7. Variação do parâmetro Sólidos Totais Dissolvidos nos pontos de amostragem.

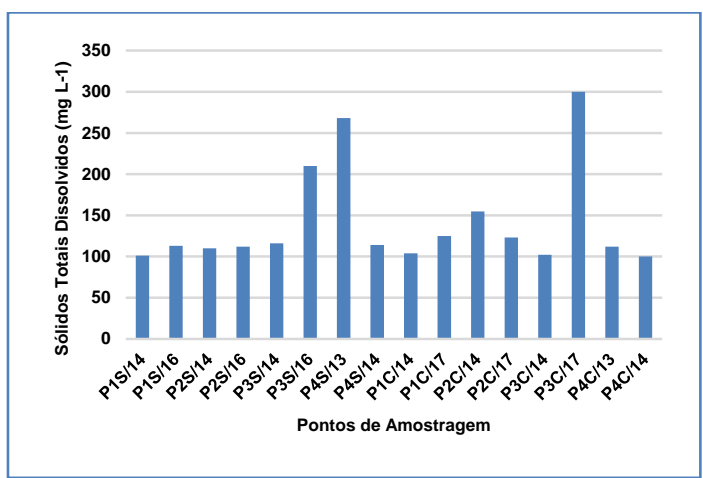


Figura 8. Variação do parâmetro Fósforo Total nos pontos de amostragem.

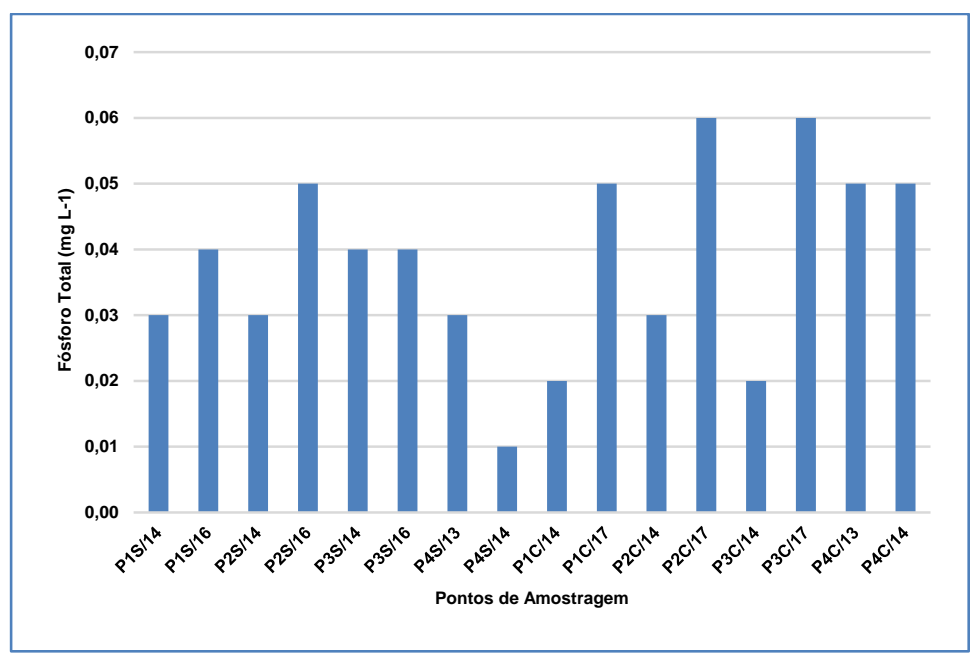

Concentrações elevadas de PT podem contribuir, da mesma forma que o nitrogênio, para a proliferação de algas e acelerar, indesejavelmente, em determinadas condições, o processo de eutrofização (HERMES et al., 2006). Silva et al. (2014) também encontraram baixos valores de fósforo total para o rio Poxim.

Os parâmetros fósforo e nitrogênio são importantes variáveis no processo de eutrofização dos corpos d'água, essenciais ao crescimento de todos os seres vivos. Em corpos hídricos, são elementos fundamentais para o controle das taxas de crescimento de algas e cianobactérias (SAWYER et al., 1994).

Na Figura 9, são observados os valores por pontos de amostragem e por sazonalidade para o parâmetro nitrogênio total.

Se observa na Figura 9, que o nitrogênio total apresentou uma elevada variação com CV\% $=27,8$ a 75,2, no período seco, e no período chuvoso variou de $\mathrm{CV} \%=16,2$ a 90,4, demostrando assim uma variação mais acentuada durante $o$ aumento da precipitação pluviométrica.

De acordo com a Resolução 357 do CONAMA para águas doces de classe 2, quando o nitrogênio for fator limitante para eutrofização, nas condições estabelecidas pelo órgão ambiental competente, o valor de nitrogênio total, após oxidação, não deverá ultrapassar 1,27 mg L-1 para ambientes lênticos e 2,18 mg L-1 para ambientes lóticos, na vazão de referência. Os valores observados na Figura 9, estão dentro do limite estabelecido pela supracitada resolução.

Com relação ao parâmetro oxigênio dissolvido (OD), Figura 10, o coeficiente de variação para o período seco foi de CV \% = 17,68 a 46,4 e no período chuvoso de CV \% = 1.89 a 14 .

Figura 9. Variação do parâmetro Nitrogênio Total nos pontos de amostragem.

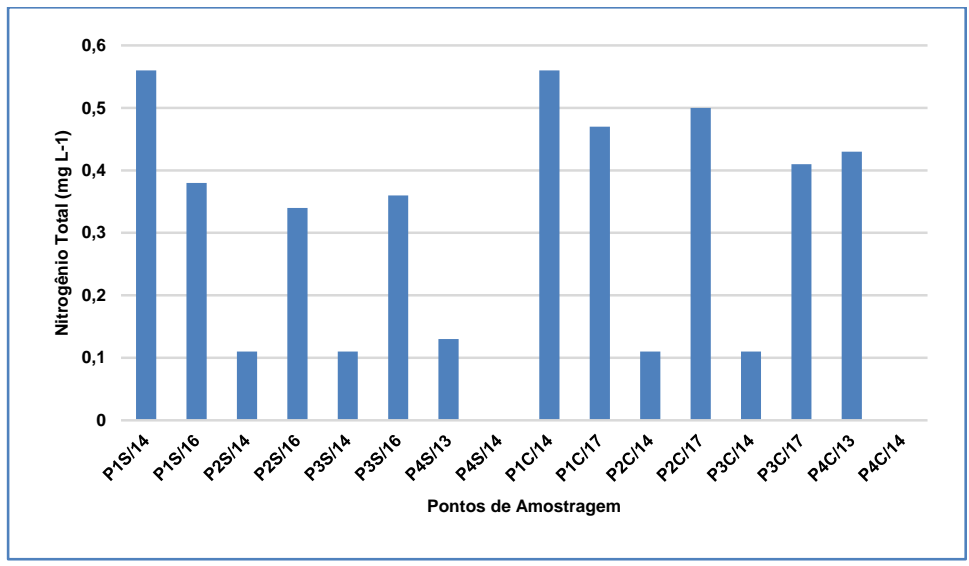


Figura 10. Variação do parâmetro Oxigênio Dissolvido nos pontos de amostragem.

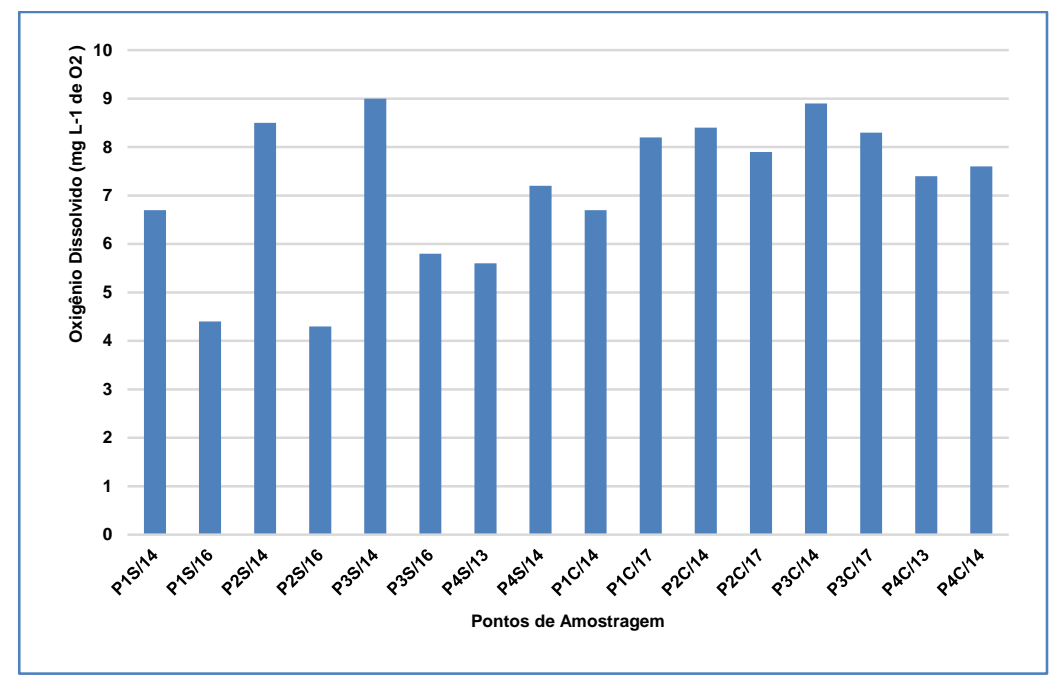

Durante o período estudado todos os valores encontrados para o OD foram de acordo com a Resolução $357 / 2005$ do CONAMA para as águas doces classe 2, acima de $5 \mathrm{mg} \mathrm{L}-1$, exceto os pontos P1/16 e P2/16 que apresentaram respectivamente 4,4 e 4,3 mg L-1 durante o período seco. Silva et al (2014), afirmam que o oxigênio dissolvido é um dos principais parâmetros para se determinar a qualidade das águas, sua presença é essencial para a manutenção e equilíbrio dos ecossistemas aquáticos e autodepuração dos mananciais.

A Figura 11, representa os valores referentes a determinação de coliformes totais na água do rio Paripe. É possível observar uma alta variação, principalmente no período chuvoso com $\mathrm{CV} \%=6,7$ a 128 e média variação no período seco com CV\% = 30 a 109.

Figura 11. Variação do parâmetro Coliformes Totais nos pontos de amostragem.

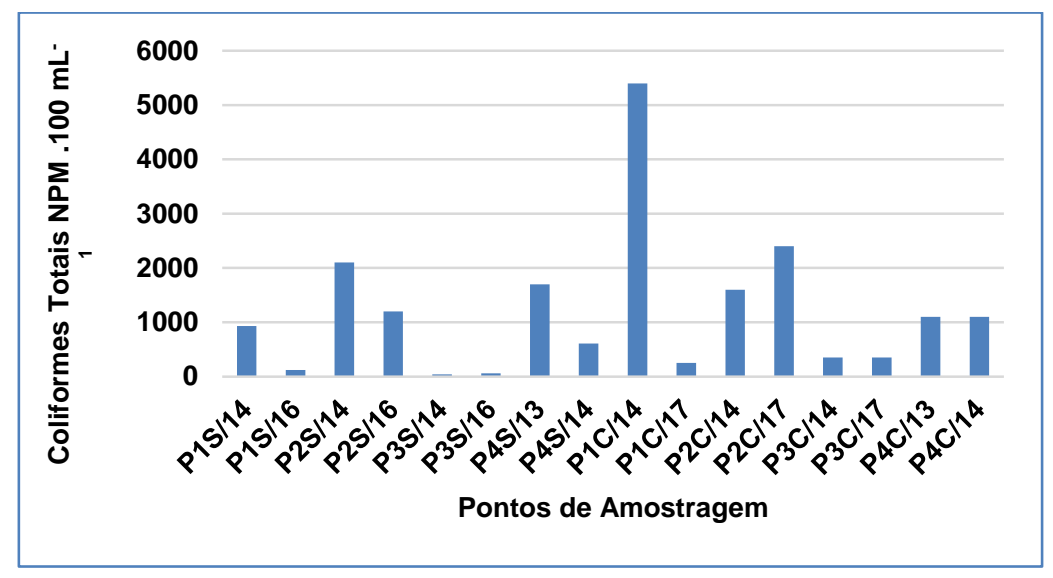

Referente à Resolução 357/2005 do CONAMA para águas doces classe 2, o limite é de 1000 NMP.100 mL1 , dessa forma os valores foram excedidos nas campanhas de P2S/14 (2100 NPM.100 mL-1), P2S/16 (1200 NPM.100 mL-1), P4S/13 (1700 NPM.100 mL-1), P1C/14 (5.400 NPM.100 mL-1), P2C/14(1600 NPM.100 mL-1) e P2C/17 (2400 NPM.100 mL-1).

A presença de coliformes pode ser explicada devido ao pastejo de animais nas margens do rio, com o escoamento superficial carreia fezes com elevado número de bactérias fecais para o corpo hídrico. A precipitação no período de coleta foi $155 \mathrm{~mm}$, influenciando para aumento do escoamento superficial, carreando material orgânico e influenciando nos valores observados para coliformes totais.

E no período seco os altos valores podem ter sido influenciados pelo fluxo de maré, principalmente no ponto 4/2014. A influência do fluxo de maré deve ser observada durante as coletas realizadas para que 
não aconteça essa alteração discrepante nos dados obtidos. Para esse tipo de influência deve-se realizar as coletas observando o nível de água em que foi realizado a primeira coleta e assim realizar as posteriores. Sendo assim a essa discrepância encontrada nos dados pode ter ocorrido devido a água do rio estar com movimento contrário a sua vazão normal e o volume muito elevado do que observado em outras campanhas. Devido a esse movimento contrário a água passa pela zona urbana do município de Indiaroba sendo contaminada por efluentes domésticos e lixo nas margens, contribuindo para essa diferenciação nos dados de coliformes totais.

A água contaminada com esses efluentes fornece riscos de veiculação de doenças, mesmo após o tratamento (SILVA et al 2014). Nos pontos P2 e P1, são pastagens nas duas margens do rio com criação de gado intensa. As fezes desses animais próximos as margens têm influência direta nos valores de coliformes.

Silveira et al (2015) realizou estudo no rio Sergipe e encontrou valores de coliformes acima dos valores máximos permitidos pela resolução CONAMA nํ․ 357/2005 para rios de classe 2, destinados para o consumo humano.

\section{2 ÍNDICE DE QUALIDADE DA ÁGUA}

Os resultados referentes ao índice de qualidade da água (IQA), calculado para cada ponto na bacia hidrográfica do Rio Paripe encontram-se na Tabela 4, em que variou de 52 a 69 no período seco e de 47 a 77 no período chuvoso.

Tabela 4. Resultado da aplicação e interpretação do cálculo do IQA (IQA-CETESB).

\begin{tabular}{|c|c|c|c|c|c|}
\hline ANO & ESTAÇÃO & \multicolumn{4}{|c|}{ CÁLCULO DO IQA } \\
\hline & & \multicolumn{2}{|c|}{ SECO } & \multicolumn{2}{|c|}{ CHUVOSO } \\
\hline 2013 & P4 & 62 & BOA & 65 & $\mathrm{BOA}$ \\
\hline \multirow{4}{*}{2014} & P1 & 52 & $\mathrm{BOA}$ & 51 & REGULAR \\
\hline & P2 & 69 & BOA & 68 & BOA \\
\hline & P3 & 62 & $\mathrm{BOA}$ & 61 & BOA \\
\hline & P4 & 63 & BOA & 67 & BOA \\
\hline \multirow{3}{*}{2016} & P1 & 64 & $\mathrm{BOA}$ & NA & \\
\hline & P2 & 57 & BOA & NA & \\
\hline & P3 & 62 & $\mathrm{BOA}$ & NA & \\
\hline \multirow{4}{*}{2017} & P1 & NA & & 77 & \\
\hline & P2 & NA & & 42 & $\begin{array}{c}\text { BUA } \\
\text { REGULAR }\end{array}$ \\
\hline & P3 & NA & & 63 & $\begin{array}{l}\text { REGULAR } \\
\text { BOA }\end{array}$ \\
\hline & P4 & NA & & NA & \\
\hline
\end{tabular}

Pode ser observado na interpretação do IQA, Tabela 3 que a qualidade da água variou de boa a regular durante o período de estudo, de modo geral, a qualidade das águas mostrou-se na maioria dos pontos estudados como boa. Os resultados do IQA classificou o corpo d'água em boa $(0,81 \%)$ e Regular $(0,13 \%)$. Segundo Pinto et al. (2009), o escoamento superficial direto é o responsável pelo transporte do material fecal para as águas influenciando na diminuição dos valores do IQA.

Conforme a Tabela 3 os coliformes termotolerantes representam o $2^{\circ}$ parâmetro mais importante dentro da determinação do IQA, sendo que este parâmetro atuou de forma direta para redução do resultado do índice. Silva et al. (2014b), ao avaliarem a qualidade das águas da microbacia do Rio Claro, encontraram resultados similares, e o atribuíram a entrada de muitos pontos difusos de carga orgânica no decorrer de todo o trecho do rio.

Ressalta-se ainda que as margens do rio são ocupadas por pastagens, sendo o pastejo constante na parte rural mais próximo ao ponto 2, contribuindo para a selagem das partículas do solo. Merten e Minella (2002) relatam que as atividades de pecuária representam grande risco à qualidade de corpos d'água, quando nestas não são realizadas práticas de manejo conservacionistas do solo e da água, elevando os valores de DBO e coliformes fecais.

Constata-se ainda a ausência de vegetação ciliar ao longo do rio, o que contribui para a entrada de sedimentos e de matéria orgânica, alterando a qualidade da água, como pode ser verificado através dos 
valores de IQA, em especial no período chuvoso, onde foram encontrados no P1 (51) e P2 (42) valores considerados baixos, resultante do cálculo deste índice.

Devido aos baixos índices encontrados no período chuvoso observa-se que à medida que a quantidade pluviométrica reduz, aumenta-se concomitantemente a qualidade da água, outros trabalhos relatam resultados semelhantes (Pinto et al,2009; Alves et al,2008; Vasco et al.,2011). A bacia do rio Paripe possui boa qualidade de água, segundo observado pelos resultados do IQA para o consumo humano, em relação aos parâmetros avaliados, contudo ressalta-se que a avaliação da qualidade da água apenas por este índice não fornece uma análise completa, pois apenas alguns parâmetros físico-químicos e biológicos compõem o IQA, não refletindo, por exemplo, a qualidade com relação aos agrotóxicos ou substâncias tóxicas como metais pesados ou hidrocarbonetos.

\section{3. ÍNDICE DE ESTADO TRÓFICO}

O valor máximo e mínimo para a concentração de fósforo foram 0,06 e 0,01 mg L-1, respectivamente. As concentrações de fósforo, na maioria das águas naturais, encontram-se entre 0,005 e 0,020 mg L-1 (CHAPMAN, 1992), valores próximos aos determinados neste trabalho. Todos os valores encontrados para este parâmetro estiveram dentro do limite estabelecido para águas doces classe 2 de acordo com a Resolução 357/2005 do CONAMA (0,1 mg L-1 P). Segundo Lamparelli (2004), as concentrações médias dos nutrientes, sobretudo o fósforo total, são mais elevadas em ambientes lóticos (0,193 mg L-1) que em ambientes lênticos (0,075 mg L-1).

A clorofila-a representa uma maneira de medir a biomassa de um reservatório através de sua produtividade primária (GARCIA et al, 2012), sendo um importante indicador do estado trófico em corpos hídricos (SILVA et al., 2014a). Os valores deste parâmetro estiveram acima do estabelecido pela Resolução $357 / 2005$ do CONAMA, que admite até $30 \mu \mathrm{g}$.L-1 para águas doces de classes 2.

No cálculo do índice de estado trófico (IET) é utilizado o resultado da análise do fósforo e da clorofila-a. 0 resultado do cálculo do IET está exposto na Tabela 5.

De acordo com a Tabela 5, os maiores graus de trofia aconteceram no período chuvoso, ou seja, período em que ainda ocorriam chuvas na região, e assim como Silva et al (2006), pode-se considerar que houve aumento do escoamento superficial aumentando a entrada de sedimentos e matéria orgânica no rio, elevando assim a quantidade de nutrientes. 0 exposto acima pode ser observado também quando se considera o período sazonal, os IET médios encontrados foram 27 e 68,6, respectivamente, ou seja, o estado trófico variou de Ultra a Hipereutrófico.

Tabela 5. Valores do Cálculo do Índice de Estado Trófico Médio (IETm) para o rio Paripe referente aos anos 2013 e 2014 para os períodos seco e chuvoso.

\begin{tabular}{c|c|c|c|c|}
\hline \multicolumn{2}{c|}{\begin{tabular}{c}
\multicolumn{2}{c}{ CALCULO DO IET } \\
2013
\end{tabular}} & \multicolumn{2}{c}{ Seco } & \multicolumn{2}{c}{ Chuvoso } \\
P4 & 34,4 & Ultraoligotrófico & 35,4 & Ultraoligotrófico \\
\hline 2014 & 49,6 & Oligotrófico & 58,6 & Mesotrófico \\
P1 & 49 & Oligotrófico & 68,6 & Hipereutrófico \\
P2 & 59,5 & Oligotrófico & 46,6 & Oligotrófico \\
P3 & 34 & Ultraoligotrófico & 27 & Ultraoligotrófico \\
P4 & & & & \\
\hline
\end{tabular}

Os resultados do IET foram classificados nas amostras como ultraoligotrófico (40\%), oligotrófico (30\%), Eutrófico (10\%), mesotrófico (10\%) e hipereutrófico (10\%). Buzelli e Cunha-Santino (2013) ao analisarem a variação sazonal do IET, observaram que entre os períodos chuvoso e seco não apresentaram variações significativas. Provavelmente o regime pluviométrico e a ação antrópica têm influenciado diretamente na qualidade da água. Segundo Santos (2008) atribuição dos aportes de esgotos sanitários e drenagem de águas pluviais urbanas e resíduos provenientes das atividades agropecuárias geram o enriquecimento dos corpos d'água por nutrientes. Devido as diversas fontes pontuais e difusas existentes 
no rio Paripe e as condições da qualidade hídrica, estudos das variáveis limnológicas do curso d'água, para que se possam planejar adequadamente, em tempo hábil, medidas que evitem maiores prejuízos ao abastecimento de água de centenas de habitantes da região e aos demais usos dos seus recursos hídricos, são de fundamental importância.

\subsection{ANÁLISE DE CORRELAÇÃo DAS VARIÁVEIS FÍSICO-QUÍMICAS E BIOLÓGICAS}

Para comparar as possíveis interações entre as variáveis físico-químicas e biológica obtidas das análises, foi aplicado o teste de correlação linear de Pearson com grau de significância $r>0,06$.

0 resultado da aplicação da análise de correlação no período seco e chuvoso está descrito na Tabela 6.

0 coeficiente de correlação Pearson (r) varia de -1 a 1.0 sinal indica a proporcionalidade da relação e o valor sugere a força da relação entre as variáveis. Dancey e Reidy (2005) apontam para uma classificação: $r=0,10$ até 0,30 (fraco); $r=0,40$ até 0,6 (moderado); $r=0,70$ até 1 (forte). As variáveis que apresentaram forte correlação foram sólidos totais e turbidez $(r=0,84)$, clorofila-A e oxigênio dissolvido $(r=0,81)$, no período seco, e oxigênio dissolvido e coliformes totais $(r=-0,77)$ no período chuvoso. Sugere-se que os parâmetros que foram destacados por possuírem forte correlação sofrem influência externa, frequentemente de origem antrópica.

A forte correlação positiva entre sólidos totais e turbidez já era esperada, devido a relação direta que possuem. Segundo Pinheiro et al. (2013) não existe uma metodologia ideal para a mensuração da concentração de sólidos totais suspensos, porém há métodos que o estimam indiretamente através da turbidez, estes ganharam aceitação dentre os vários métodos de monitoramento.

Tabela 6. Análise de Correlação de Pearson das variáveis físico-químicas e biológicas da qualidade da água representando o período seco e chuvoso respectivamente.

\begin{tabular}{|c|c|c|c|c|c|c|c|c|c|c|}
\hline PS1 & $\mathrm{PH}$ & DBO & $\mathrm{T}^{\circ} \mathrm{C}$ & TUR & STD & PT & NT & CT & OD & CL-A \\
\hline $\mathrm{PH}$ & 1 & & & & & & & & & \\
\hline DBO & $-0,12$ & 1 & & & & & & & & \\
\hline $\mathrm{T}^{\circ} \mathrm{C}$ & $-0,17$ & 0,28 & 1 & & & & & & & \\
\hline TUR & 0,68 & 0,10 & $-0,30$ & 1 & & & & & & \\
\hline STD & 0,65 & $-0,06$ & 0,06 & 0,84 & 1 & & & & & \\
\hline PT & $-0,39$ & 0,74 & 0,41 & $-0,09$ & 0,01 & 1 & & & & \\
\hline NT & $-0,49$ & 0,12 & 0,20 & $-0,35$ & $-0,14$ & 0,50 & 1 & & & \\
\hline $\mathrm{CT}$ & 0,35 & 0,19 & $-0,74$ & 0,44 & 0,14 & $-0,17$ & $-0,22$ & 1 & & \\
\hline OD & $-0,29$ & $-0,11$ & $-0,04$ & $-0,14$ & $-0,25$ & $-0,41$ & $-0,51$ & 0,09 & 1 & \\
\hline CL-A & $-0,42$ & 0,02 & 0,02 & $-0,17$ & $-0,37$ & $-0,34$ & $-0,14$ & $-0,02$ & 0,81 & 1 \\
\hline PC2 & $\mathrm{PH}$ & DBO & $\mathrm{T}^{\circ} \mathrm{C}$ & TUR & STD & PT & NT & CT & OD & CL-A \\
\hline $\mathrm{PH}$ & 1 & & & & & & & & & \\
\hline DBO & $-0,60$ & 1 & & & & & & & & \\
\hline $\mathrm{T}^{\circ} \mathrm{C}$ & $-0,58$ & 0,48 & 1 & & & & & & & \\
\hline TUR & $-0,63$ & 0,77 & 0,48 & 1 & & & & & & \\
\hline STD & $-0,22$ & 0,00 & 0,38 & 0,60 & 1 & & & & & \\
\hline PT & 0,03 & 0,36 & 0,18 & 0,60 & 0,43 & 1 & & & & \\
\hline NT & $-0,36$ & 0,34 & 0,54 & 0,24 & 0,15 & 0,25 & 1 & & & \\
\hline CT & $-0,17$ & 0,05 & $-0,18$ & $-0,19$ & $-0,31$ & $-0,41$ & 0,43 & 1 & & \\
\hline OD & $-0,32$ & 0,21 & 0,39 & 0,37 & 0,31 & 0,02 & $-0,47$ & $-0,77$ & 1 & \\
\hline CL-A & $-0,26$ & $-0,07$ & $-0,30$ & $-0,01$ & $-0,04$ & $-0,59$ & $-0,53$ & $-0,05$ & 0,47 & 1 \\
\hline
\end{tabular}


Há forte correlação positiva entre clorofila-A e oxigênio dissolvido $(r=0,81)$, ocorre devido a necessidade do oxigênio para as realizações fotossintéticas das plantas no corpo hídrico, onde as principais fontes de oxigênio são a atmosfera, através da interface atmosfera-água, e a fotossíntese, que é a produção e liberação do oxigênio pelos organismos fitoplanctônicos e plantas aquáticas (UNESP 2018). No período chuvoso ocorreu correlação forte e negativa entre oxigênio dissolvido e coliformes totais $(r=-0,77)$, devido a presença de matéria orgânica e bactérias termotolerantes sendo responsável pelo principal problema de poluição das águas, acarretando na redução na concentração de oxigênio dissolvido. Isto ocorre como consequência da atividade respiratória das bactérias para a estabilização da matéria orgânica (UNESP 2018).

\subsection{ANÁLISE DE COMPONENTES PRINCIPAIS (PCA)}

Foi aplicado aos dados físicos, químicos e biológicos de qualidade da água do rio Paripe a análise de componentes principais exceto para o parâmetro clorofila-a devido à falta de dados completos para comparar a sazonalidade. Então o cálculo foi realizado com 9 variáveis e 16 amostras (8 período seco e 8 período chuvoso) para melhor observação do comportamento das variáveis estudadas no período sazonal.

A descrição dos pesos das variáveis para os períodos seco e chuvoso e as componentes principais resultantes da análise estão descritas na Tabela 7.

No período seco a PC1, explica 35,49 \% e a PC2 explica 24,61 \% para o período chuvoso juntas ela possuem uma variação total de $60 \%$ sendo suficientes para explicar a variação do conjunto de dados analisados. Já no período chuvoso a PC1, explica 39,89 \% e a PC2 explica 24,73 \%, juntas explicam 69,8 \% da variação acumulada total, sendo suficientes para identificação da variabilidade dos dados da análise das componentes principais.

Tabela 7. Variáveis e pesos das duas componentes principais para água do rio Paripe.

\begin{tabular}{|c|c|c|c|c|}
\hline \multirow{2}{*}{ Variáveis } & \multicolumn{2}{|c|}{ PERÍODO SECO } & \multicolumn{2}{|c|}{ PERÍODO CHUVOSO } \\
\hline & PC1 & PC2 & PC1 & PC2 \\
\hline $\mathrm{pH}$ & 0,818058 & $-0,302210$ & $-0,703882$ & 0,324459 \\
\hline DBO & $-0,279564$ & $-0,581203$ & 0,737275 & $-0,295230$ \\
\hline $\mathrm{T}$ & $-0,567499$ & $-0,300027$ & 0,761189 & $-0,140792$ \\
\hline TUR & 0,797370 & $-0,487618$ & 0,921595 & $-0,001123$ \\
\hline STD & 0,606169 & $-0,598752$ & 0,590895 & 0,261078 \\
\hline PT & $-0,584468$ & $-0,699179$ & 0,548204 & 0,144931 \\
\hline NT & $-0,633018$ & $-0,351039$ & 0,388199 & $-0,770757$ \\
\hline ColT & 0,610799 & $-0,029448$ & $-0,296010$ & $-0,886150$ \\
\hline OD & 0,076509 & 0,697427 & 0,483986 & 0,738507 \\
\hline Variância (\%) & 35,49 & 24,61 & 39,89 & 24,73 \\
\hline Variância Total (\%) & \multicolumn{2}{|c|}{60,10} & \multicolumn{2}{|c|}{64,62} \\
\hline
\end{tabular}

Essa relação entre fatores e variáveis permitem identificar as maiores inter-relações em cada componente. Os valores elevados dos pesos fatoriais sugerem quais são as variáveis mais significativas em cada fator (componente). No diagrama de dispersão podemos perceber a influência de cada variável em cada componente principal, Figura 12.

Podemos perceber que a PC1 e a PC2 no período seco geraram dois grupos distintos formados pelas variáveis com maior peso e que contribuíram com 60,9 \% da variância total dos dados. As variáveis $\mathrm{pH}$ $(0,82)$, TUR $(0,80)$, STD $(0,61)$ e colT $(0,61)$ apresentam maiores contribuições e positivas na PC1, enquanto que DBO $(-0,28)$, T $(-0,57)$, PT $(0,58)$ e NT $(0,63)$ apresentaram pesos negativos nesta PC. Com isso sugere-se que as variáveis identificadas foram influenciadas pela ação antrópica, da extração de areia, que acontece em três dos quatros pontos avaliados no rio Paripe e pastejo de animais no entorno do rio 
abrangendo todos os pontos de coleta. Esses resultados só intensificam a discussão do impacto gerado pela extração de areia no leito de rios.

O parâmetro OD foi a única variável que está influenciando positivamente na PC2, apresentando resultados diferentes do encontrado por Silveira et al (2015), que encontrou resultados significativos para OD em duas das três componentes principais, no entanto com contribuição negativa. Os valores observados para o OD estão de acordo com a Resolução 357/2005 (CONAMA). Sua interpretação se torna complexa devido a variações diárias, pois é um gás que está diretamente envolvido com o processo de fotossíntese e respiração e/ou decomposição que, por sua vez, estão inteiramente relacionadas com o fotoperíodo, a intensidade luminosa e a temperatura (ESTEVES 1998).

Figura 12. Diagrama de dispersão da PC1 e PC2 para o período seco das variáveis de qualidade da água do rio Paripe.

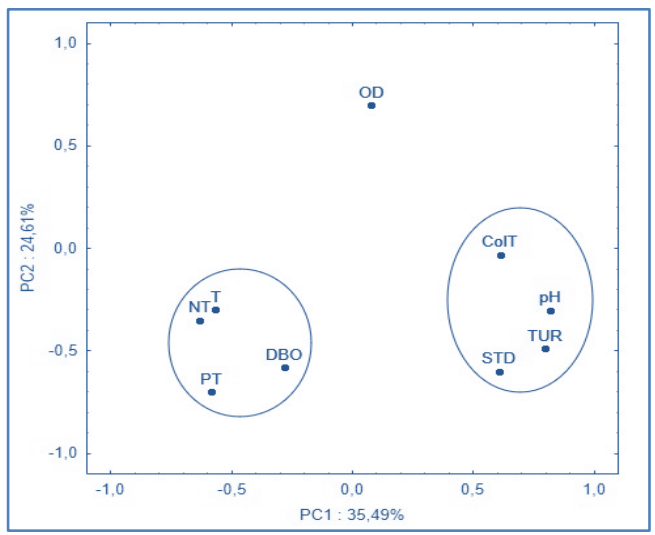

Figura 13. Diagrama de dispersão da PC1 e PC2 para o período chuvoso das variáveis de qualidade da água do rio Paripe.

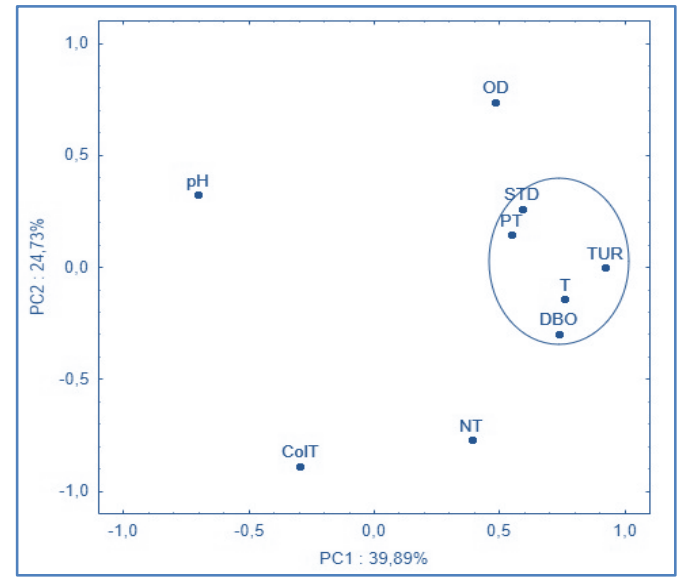

Para o período chuvoso as duas primeiras PC's juntas explicam 64,6\% da variância total dos dados. As variáveis T $(0,76)$, DBO $(0,74)$, PT $(0,55)$ STD $(0,59)$, TUR $(0,92)$ foram as principais responsáveis pela variância no eixo da PC1, com 39,89 \% de variância, influenciando positivamente. Destaca-se no eixo da PC2 as variáveis NT $(-0,77)$ e col-T $(-0,89)$, negativamente, e OD $(0,74)$, positivamente. Essas variáveis destacadas podem ser influenciadas pelo escoamento superficial, principalmente no período chuvoso. 0 OD não demostrou diferença entre período sazonal demostrando o mesmo comportamento para ambos os períodos estudados.

A avaliação da sazonalidade em relação aos pontos de coleta pode ser observada pela análise de agrupamento hierárquico (HCA), representado pelo dendograma, Figura 14. 
Figura 14. Dendograma dos pontos de amostragem divididos pela sazonalidade do rio Paripe relativo ao cálculo da distância Euclidiana e método de ligação de Ward's.

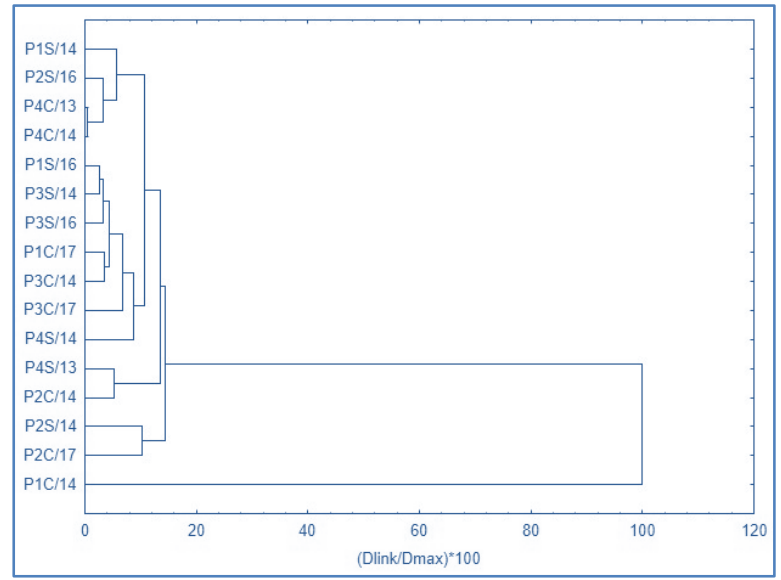

Legenda: $\mathrm{P}=$ são pontos de coletas; $\mathrm{S}=$ período seco; $\mathrm{C}=$ período chuvoso; $\mathrm{o}$ último número se refere ao ano em que fo feito a coleta em dois dígitos.

Sugere-se que ao diminuir o processo de extração de areia, devido ao período com maior precipitação que inviabiliza a prática, os parâmetros que se agregaram demostrando semelhança foram diferentes quando comparado ao período seco.

De acordo com o dendograma percebe-se que não houve a formação de diferentes agrupamentos, considerando os períodos sazonais. Porém devido a práticas inadequadas de exploração, no entorno e no leito do rio, a qualidade da agua do rio Paripe tem sido fortemente agredida.

\section{CONCLUSÃO}

A verificação da qualidade da água por meio de parâmetros pré-estabelecidos foi útil quando avaliados e correlacionados ao manejo e diferentes usos e ocupação do solo, percebendo drásticas consequências causada na qualidade da água, práticas essas exercidas tanto nas margens quanto no leito do rio.

A mensuração da qualidade da água por meio do índice de qualidade (IQA) variou de Boa a Regular, na maioria dos pontos foi interpretado como de qualidade boa, mas a orientação a população do entorno e aos órgãos competentes que deve-se atentar-se a adoção de práticas de manejo adequadas para melhorar cada vez mais a qualidade da água.

Na avaliação do índice de estado trófico (IET) do rio Paripe foi possível identificar um aumento dos níveis tróficos no período chuvoso e a influência antrópica trazendo consequências para a qualidade da água. 0 estado trófico nos pontos estudados variou de ultra a hipereutrófico. Na análise de Correlação foi identificado as variáveis físico-químicas e biológicas que possuem inter-relações entre si, foi constatado que parâmetros vem sofrendo alteração devido a influência de pratica de extração de areia, influenciando principalmente nos valores das variáveis Turbidez, sólidos Totais, Oxigênio Dissolvido e Clorofila-A. As variáveis citadas anteriormente demostraram correlação forte e positiva.

Na análise de Componentes Principais aplicado a 9 diferentes variáveis de 16 amostras, sendo comparadas sazonalmente, período seco e chuvoso. No período seco as componentes principais explicaram 60,9\% da variação total dos dados para os pontos estudados e foram influenciadas pela ação de extração de areia de rio. No período chuvoso as componentes obtidas com maior percentagem de explicação (64,6\%), pode ser explicada devido ao período chuvoso com aumento da pluviosidade que acarreta no carreamento de particulados e material orgânico para o leito do rio.

A análise de Cluster exemplificado no dendograma pode ser explicado que à medida que a prática de extração de areia diminui os parâmetros semelhantes agregados foram diferentes quando a extração de areia é contínua. Demostrando que a prática vem causando degradação nos parâmetros físicos principalmente. 


\section{REFERÊNCIAS}

[1] AGUIAR NETTO, A. 0; et all. Physical and chemical characteristics of water from the hydrographic basin of the Poxim River, Sergipe State, Brazil. Environmental Modeling and Assessment, v. 184, p. 4417-4426, 2013.

[2] ALVES, E. C., SILVA, C. F. D; COSSICH, E. S.; REGINA, C.; G. TAVARES; E. E. D. FILHO S.; CARNIEL, A; Avaliação da qualidade da água da bacia do rio Pirapó - Maringá, Estado do Paraná, por meio de parâmetros físicos, químicos e microbiológicos; Acta Sci. Technol. Maringá, v. 30, n. 1, p. 39-48, 2008.

[3] APHA. AMERICAN PUBLIC HEALTH ASSOCIATION. Standard Methods for Examination of Water and Wastewater. 20th Edition, 2005. SMEWW 9222 A, B, C, D, E.

[4] ARCOVA, F. C. S.; CICCO, V. Qualidade da água de microbacias com diferentes usos do solo na região de Cunha, Estado de São Paulo. Scientia Forestalis (IPEF), PIRACICABA, n. 56, p. 125-134, 1999.

[5] BARRETO, L. V.; FRAGA, M. S.; BARROS, F. M.; ROCHA, F. A.; AMORIM, J. S.; CARVALHO, S. R.; BONOMO, P.; SILVA, D. P. Relação entre vazão e qualidade da água em uma seção de rio. Ambiente \& Água, v. 9, n. 1, p. 118-129, 2014.

[6] BARRETO, P. R.; GARCIA, C. A. B.; Caracterização da qualidade da água do açude Buri-Frei Paulo/SE, Scientia Plena, v. 6, n. 9, 2010.

[7] BUZELli, G. M.; CUNHA-SANTinO, M. B. Análise e diagnóstico da qualidade da água e estado trófico do reservatório de Barra Bonita (SP). Ambi-Agua, Taubaté, v. 8, n. 1, p. 186-205, 2013.

[8] CHAPMAN, D. Water quality assessment. A guide to the use of biota, sediments and water in environmental monitoring. 1. ed. UNESCO / WHO / UNEP. Chapman \& Hall. 585p.

[9] CONSELHO NACIONAL DO MEIO AMBIENTE - CONAMA. Resolução no 357 de 17 de março de 2005. Dispõe sobre a classificação dos corpos de água e diretrizes ambientais para o seu enquadramento, bem como estabelece as condições e padrões de lançamento de efluentes, e dá outras providências. Disponível em: < http://www.mma.gov.br/port/conama//res/res05/res35705.pdf >. Acesso em: 18.03.18.

[10] CONSELHO NACIONAL DO MEIO AMBIENTE - CONAMA. Resolução no 430 de 13 de maio de 2011. Dispõe sobre a classificação dos corpos de água e diretrizes ambientais para o seu enquadramento, bem como estabelece as condições e padrões de lançamento de efluentes, e dá outras providências. Disponível em: < http://www.mma.gov.br/port/conama/res//res11/propresol_lanceflue_30_e31mar11.pdf>. Acesso em: 18.02.18. Eletrônica. v. 9. n. 3. 2010.

[11] CONSELHO NACIONAL DO MEIO AMBIENTE (CONAMA). Resolução no 357, de 17 de março de 2005. Dispõe sobre a classificação dos corpos de água e diretrizes ambientais para o seu enquadramento, bem como estabelece as condições e padrões de lançamento de efluentes, e dá outras providências. Diário Oficial [da] União, n. 53, 18 mar. 2005, p. 58-63.

[12] CORBETT, E. S.; SPENCER, W. Effects of management practices on water quality and quantity: Baltimore, Maryland, Municipal Watersheds. In: MUNICIPAL WATERSHED MANAGEMENT SYMPOSIUM, 1973. Proceedings. USDA Forest Service, General Technical Report NE-13, p.25-31, 1975.

[13] DANCEY, C.; REIDY, J.; Estatística Sem Matemática para Psicologia: Usando SPSS para Windows. Porto Alegre, Artmed (2006).

[14] ESTEVES, F. A. Fundamentos de Limnologia. 3aㅡ ed. Rio de Janeiro: Interciência. 2011.

[15] FAO - FOOD AND AGRICULTURE ORGANIZATION, 1985, Water quality for agriculture. Disponível em: http://www.fao.org/HTM . Acesso em: 13/10/2017.

[16] FARIAS, M. S. S. Monitoramento da Qualidade da Água na Bacia Hidrográfica do Rio Cabelo. 2006, Tese (Doutorado em Irrigação e drenagem). Campina Grande, UFCG. Campina Grande, Estado da Paraíba Julho - 2006. $136 \mathrm{p}$.

[17] GARCIA H. L. et al., Nível trófico do reservatório de Jacarecica I, Sergipe, Brasil Scientia Plena, Vl. 8, (2012).

[18] HERMES, L. C. et al. Considerações gerais e monitoração de qualidade de água. In: FAY, E. F.; SILVA, C. M. M. S. Índice do uso sustentável da água (ISA-ÁGUA) região do sub-médio São Francisco. Jáguariúna: Embrapa Meio Ambiente, 2006. P. 17-41.

[19] JIAN, C-Y, S-Y CHENG \& J-C CHEN. 2003. Temperature and salinity tolerances of yellowfin sea bream, Acanthopagrus lotus, at different salinity and temperature levels. Aquaculture Research, 34:175-185.

[20] LAMPARELli , M. C. Grau de trofia em corpos d'água do estado de São Paulo: avaliação dos métodos de monitoramento. São Paulo : USP/ Departamento de Ecologia., 2004. 235 f. Tese de doutorado, Universidade de São Paulo, 2004

[21] LIMA, E. B. N. R. Modelação integrada para gestão da qualidade da água na bacia do rio Cuiabá. 2001. 206f. Tese (Doutorado em Ciências em Engenharia Civil) - Instituto Alberto Luis Coimbra de Pós-Graduação e Pesquisa de Engenharia, Universidade Federal do Rio de Janeiro, Rio de Janeiro, 2006. 
[22] MARTINS C. T.; FIOROTTI J. L.; SIMAN R.; XIV Encontro Latino Americano de Iniciação Científica e X Encontro Latino Americano de Pós-Graduação - Universidade do Vale do Paraíba, 2010, Efeitos do despejo de efluentes domésticos no rio guaxindiba em Aracruz - ES [s.l.]: inicepg, 2010. 4p. disponível em: <http://www.inicepg.univap.br/cd/inic_2010/anais/arquivos/re_0236_0625_01.pdf>. acesso em: 16 abr. 2018

[23] MERTEN, G. H.; MINELLA, J. P. Qualidade da água em bacias hidrográficas rurais: um desafio atual para sobrevivência futura. Agroecologia e Desenvolvimento Rural Sustentável, Porto Alegre, v. 3, n. 4, out./dez. 2002.

[24] NOGUEIRA G. R. F. A extração de areia em cursos d'água e seus impactos: proposição de uma matriz de interação. Universidade Federal de Juiz de Fora, Curso de Engenharia Embiental e Sanitária, Trabalho de Conclusão de Curso. Faculdade de Engenharia da UFJF 2016.

[25] NETTO, A. O. A; GOMES L.J.; Meio ambiente: distintos olhares- São Cristóvão: Editora UFS, 2010.178p

[26] PAULEY, G. B., Thomas G. L., Marino D. A., Weigand D. C. 1989. Evaluation of the effects of gravel bar scalping on juvenile salmonids in the Puyallup River drainage. Coop. Fish. Res. Unit, Univ., 1620,150 p.

[27] PINHEIRO, E. A. R.; ARAÚJO, J. C. DE; FONTENELE, S. DE B.; LOPES, J. W. B. Calibração de Turbidímetro e análise de confiabilidade das estimativas de sedimento suspenso em bacia semiárida. Water Resources and Irrigation Management, Campina Grande, v.2, n.2, p.103-110, mar./ago. 2013.

[28] PINTO, D. B. F. Qualidade dos recursos hídricos superficiais em sub-bacias hidrográficas da região Alto Rio Grande - MG. 2007. 89 p. Dissertação (Mestrado em Engenharia de Água e Solo) - Universidade Federal de Lavras, Lavras, 2007.

[29] REBoUÇAS, A. C; BRAGA, T., GALÍZIA, J. (Org.) Águas Doces no Brasil Capital Brasil Ecológico Uso e Conservação. São Paulo, Escrituras, p.1-38. 2006.

[30] REIS, L. V. S.; Cobertura florestal e custo do tratamento de águas em bacias hidrográficas de abastecimento público: caso do manancial do município de Piracicaba. Tese (doutorado) - Escola Superior de Agricultura Luiz de Queiroz, 215 p, 2004.

[31] RIVERA, E. A. C., Modelo Sistêmico para Compreender o Processo de Eutrofização em um Reservatório de Água. 2003. Tese de Doutorado. Dissertação de mestrado do programa da Faculdade de Engenharia de Alimentos, Universidade Estadual de Campinas-São Paulo.

[32] RUNDQUIST, L. A. Effects of gravel removal on river hydrology and hydraulics. Fish Wildl. Serv.1980.

[33] SAWYER, C. N.; McCARTY, P. L.; PARKIN, G. F. Chemidtry for envitonmental engineering. 4o ed. New York: McGraw-Hill . 1994. 658p.

[34] SEMARH - Secretaria de Meio Ambiente e Recursos Hídricos do Estado de Sergipe. Governo de Sergipe.

[35] SHIKLOMANOV, I. Word water resources: a new appraisal and assessment for the 21st century. Paris: UNESCO, 1998. 32p.

[36] SILVA, M. G et al. A qualidade da água na bacia hidrográfica do rio Poxim. A qualidade da água na bacia hidrográfica do rio Poxim. In: VASCO, A. O. WANDERLEY, L.L.; SILVA, M.G. (Org.). Rio Poxim, o rural, o urbano e o ambiental na bacia hidrográfica. Aracaju: EDIFS, 2014a.

[37] SILVA, M. G. Caracterização da qualidade da água na barragem do perímetro irrigado Jacarecica I, Itabaiana Sergipe. 2006, 74p. Dissertação (Mestrado em Agroecossistemas) - Universidade Federal de Sergipe.

[38] SILVEIR, A. A.; M., E. A. PASSOS, J. P. H. ALVES; M. N. MARQUES, Avaliação da qualidade da água da bacia hidrográfica do rio Sergipe usando análise multivariadas de dados; $2^{\circ}$ Congresso Internacional (RESAG), 2015.

[39] SPERLING, V. M. (1996). Introdução à qualidade das águas e ao tratamento de esgotos. 2 ed. Belo Horizonte: Departamento de Engenharia Sanitária e Ambiental - UFMG.

[40] SUGIMOTO, S.; NAKAMURA, F.; ITO, A. Heat budget and statistical analysis of the relationship between stream temperature and riparian forest in the Toikanbetsu river basin, Northern Japan. Journal of forest research, v.2, n.2, p.103-107, 1997.

[41] SWIFT, J. R, L. W.; MESSER, J. B. Forest cuttings raise temperatures of small streams in the southern Appalachians. Journal of soil and water conservation, v.26, n.3, p. $111-117,1971$.

[42] TUNDISI, J. G.; MATSUMURA TUNDISI, T. Limnologia. São Paulo: Oficina de Textos, 2008. 632 p.

[43] UNESP; Variáveis e parâmetros de qualidade de água em rios e reservatórios, monitoramento da qualidade da agua em rios e reservatório. disponível em: https://capacitacao.ead.unesp.br/dspace/bitstream/ana/76/6/Unidade_3.pdf. Acesso em: 21.03.2018

[44] VASCO, A. N.; BRITTO, F. B.; PEREIRA, A. P. S.; MÉLlO JÚNIOR, A. V. M.; GARCIA, C. A. B.; NOGUEIRA, L. C. Avaliação espacial e temporal da qualidade da água na sub-bacia do rio Poxim, Sergipe, Brasil. Ambi-Agua, Taubaté, v. 6, n. 1, p. 118-130, 2011. (doi:10.4136/ambi-agua.178). 
[45] ZUMACH, R. Enquadramento de curso de água Rio Itajaí- Açu e seus principais afluentes em Blumenau. Florianópolis, 2003. 124 p. Dissertação (Mestrado) - Universidade Federal de Santa Catarina, Centro Tecnológico. Programa de Pós-Graduação em Engenharia Ambiental. 


\section{Capítulo 7}

Lógica fuzzy aplicada a predição da qualidade da água do reservatório da Macela-SE

\section{Igor Santos Silva}

Maria Caroline Silva Mendonça

Helenice Leite Garcia

Silvânio Silvério Lopes da Costa

Carlos Alexandre Borges Garcia

Resumo: A avaliação da qualidade da água em reservatórios tornou-se primordial e essencial para definição de seu estado trófico. Algumas técnicas computacionais para descrever e prever problemas ambientais em água têm sido desenvolvidas através da determinação de índices de qualidade da água. Entre as técnicas de inteligência artificial, a lógica fuzzy tem se destacado na obtenção desses índices em função de parâmetros ambientais, como concentrações de clorofila-a, nitrogênio, fósforo e oxigênio dissolvido. Neste artigo, esses parâmetros foram utilizados para determinar o Índice de Qualidade da Água para Reservatórios utilizando a logica fuzzyj (IQAfuzzy) e os resultados foram comparados com outros índices da literatura. 0 ambiente de estudo foi o reservatório da Macela, localizado no município de Itabaiana, no Estado de Sergipe, Brasil. 0 índice obtido através da lógica fuzzy foi igual a 6,3 estando na mesma faixa numérica verificada na literatura utilizando outros métodos. Esses resultados mostram que o reservatório está extremamente poluído exigindo políticas de gestão ambiental urgentes, a fim de reduzir os efeitos do processo de eutrofização possibilitando um uso mais adequado da água.

Palavras-chave: Qualidade da Água, Eutrofização, Lógica Fuzzy. 


\section{INTRODUÇÃO}

Ao se pensar na qualidade da água é necessário avaliar o que tem sido feito para que a mesma continue sendo fonte de vida em meio a poluição por diversos agentes, e analisar se os tipos de tratamentos têm sido eficazes para que o seu reaproveitamento seja sustentável. A taxa de aumento de atividades urbanas, agrícolas e industriais tem levantado preocupações dos cientistas sobre questões ambientais e em particular sobre a poluição da água. Assim, muito esforço tem sido feito no desenvolvimento de um índice global que seja representativo da qualidade da água.

O resultado da qualidade de uma amostra de água não é apenas informar se esta é própria ou imprópria para o consumo, pois existe uma infinidade de possibilidades entre esses dois extremos. A amostra pode ser avaliada como boa, moderada ou ruim, por exemplo, a depender dos critérios utilizados para classificação. Além disso, o procedimento como a amostra foi coletada também interfere diretamente nos resultados, e para isso existem diversas formas analíticas que podem ser aplicadas na determinação dos parâmetros de avaliação de água (OCAMPO-DUQUE et al, 2012; GHARIBI et al, 2012).

Importante também ressaltar que as metas de qualidade ambiental são definidas levando em consideração a capacidade do corpo d'água para manter sua forma natural em processos de autolimpeza, bem como a sua capacidade para suportar a vida selvagem e vegetação, influenciando enormemente tanto quantitativa como qualitativamente sobre o corpo d'água e ecossistemas, conforme comenta (SCANNAPIECO et al 2012).

Há diversos parâmetros de classificação da água que podem ser representativos para um sistema que traduzem matematicamente o que está sendo avaliado, denominado de índice. 0 Índice de Qualidade de Água bruta para abastecimento Público (IAP), o Índice de qualidade de Água para proteção da Vida aquática (IVA) e o Î́ndice de Qualidade de Água (IQA) são alguns dos índices mais utilizados ao se avaliar amostras de água. Em reservatórios, o Índice de Estado Trófico (IET) é o parâmetro utilizado para caracterizar a água nesses sistemas nos quais a eutrofização é comum. A eutrofização é um processo que pode ser natural ocorrendo em todos lagos e reservatórios, ou devida a intervenção humana, aumentando o fluxo de nutrientes para o corpo hídrico, acelerando, assim, este processo.

Sendo assim, torna-se imperativo que se desenvolva um índice numérico para descrever o comportamento desses corpos d'água. Neste contexto, a utilização de métodos convencionas de avaliação resulta, algumas vezes, em dados imprecisos, ambíguos e difíceis de interpretação, não lineares e difíceis de formular. Esses índices são muito complexos e para serem quantificados necessita-se do conhecimento das quantidades presentes no reservatório, através da análise de muitas variáveis, como Oxigênio Dissolvido (OD), Clorofila-a, pH, nutrientes (nitrogênio e fósforo), que os compõe. Sendo assim, um índice mais simples de ser calculado é o desenvolvido pelo Instituto Ambiental do Paraná (IQAR) que permite estimar com razoável precisão esses valores baseado em um número representativo de variáveis (LERMONTOV et al, 2009).

Os valores do IQAR foram classificados conforme apresentado na Quadro 1, e os reservatórios são classificados, através das médias aritméticas dos parâmetros ambientais analisados.

Quadro 1: Classificação da Qualidade de Água (IAP, 2014)

\begin{tabular}{|c|c|}
\hline \multicolumn{1}{|c|}{ Valor do IQAR } & Qualificação \\
\hline $0 \leq \mathrm{IQAR} \leq 1,50$ & não impactado a muito pouco degradado \\
\hline $1,51 \leq \mathrm{IQAR} \leq 2,50$ & pouco degradado \\
\hline $2,51 \leq \mathrm{IQAR} \leq 3,50$ & moderadamente degradado \\
\hline $3,51 \leq \mathrm{IQAR} \leq 4,50$ & criticamente degradado a poluído \\
\hline $4,51 \leq \mathrm{IQAR} \leq 5,50$ & muito poluído \\
\hline $\mathrm{IQA}>5,51$ & extremamente poluído \\
\hline
\end{tabular}

Segundo Abbasi e Abbasi (2012), o IQAR necessita de um número limitado de variáveis para o seu cálculo, pois, um número muito elevado de parâmetros torna o cálculo muito difícil e com resultados complicados de serem interpretados. Sendo assim, neste trabalho os parâmetros utilizados foram o Nitrogênio Total, 
Fósforo Total, Clorofila-a e o OD, que, para os especialistas, são os parâmetros mais representativos da avaliação de um corpo d'água.

Inserida nessa análise e interpretação, a inteligência artificial (redes neurais, lógica fuzzy, algoritmos genéticos) é um recurso que vem sendo utilizado para solucionar problemas complexos. Para que os computadores tenham a capacidade de desenvolver padrões e aprender com estes foram desenvolvidas as redes neurais para descrever muitos fenômenos. Ainda no contexto da inteligência artificial, a lógica fuzzy, desenvolvida por Dr. Zadeh em 1965, vem tendo também, destaque em diferentes áreas do conhecimento. A lógica fuzzy representa uma mudança significativa tanto na abordagem como no resultado das avaliações ambientais. A principal vantagem dos métodos da lógica fuzzy frente à booleana é a gama de respostas boas ou ruins que esta pode oferecer, saindo do campo restrito do verdadeiro ou falso, ampliando para uma gama maior de possibilidades que podem ser dadas como resposta, em situações que verdadeiro ou falso não seriam respostas precisas ou adequadas (ZADEH, 1965; MCKONE E DESHPANDE, 2005; CABANILLAS et al, 2012).

Os métodos desenvolvidos nesse sistema são sintetizados criando-se um programa computacional baseado em regras criadas a partir desta lógica, que se denomina controlador fuzzy. Uma aplicação muito recorrente da lógica fuzzy é na compreensão dos índices de qualidade da água em reservatórios, por exemplo, retirando a instabilidade muitas vezes vistas nos métodos anteriormente desenvolvidos, devido a ampla faixa que essa lógica difusa ou nebulosa pode tratar, diferentemente da lógica booleana (GABRIEL, 2008). Neste sentido, a inteligência artificial tem se tornado uma estratégia de análise muito mais precisa e eficaz com um poder de análise muito mais rico.

O objetivo deste trabalho é a aplicação da lógica fuzzy para descrever o comportamento ambiental e avaliar os índices e parâmetros do reservatório da Macela, no interior do Estado de Sergipe. Para tal, foi realizada uma análise comparativa entre os resultados obtidos para um IQAR calculado pela lógica fuzzy e os outros métodos apresentados na literatura. 0 modelo desenvolvido através do método fuzzy aplicado ao reservatório objetiva avaliar os níveis de qualidade do mesmo em relação aos parâmetros físicos, químicos e microbiológicos para que seja definido um melhor aproveitamento da água.

\section{LÓGICA FUZZY}

Os conjuntos fuzzy são definidos em sua forma através de sua função de pertinência que mostra à intensidade com que o objeto pertence ao conjunto fuzzy. Existem várias formas de representar uma função fuzzy de pertinência, sendo que, as mais usuais são a triangular, gaussiana, trapezoidal, sigmóide bipolar, S e quadrática, sendo todas definidas no intervalo de pertinência de 0 a 1 (ZADEH, 1965).

Neste trabalho, utilizou-se da função triangular que é caracterizada por uma terna $(a, b, c)$ sendo que a e c determinam o intervalo para o qual a função identifica valores diferentes de zero, e b representa o ponto no qual a função de pertinência é máxima. Portanto, os números fuzzy começam a subir a partir de zero quando $\mathrm{x}=\mathrm{a}$, encontram o valor máximo em $1, \mathrm{x}=\mathrm{b}$, e retornam a zero em $\mathrm{x}=\mathrm{c}$. A função $\mu \mathrm{F}(\mathrm{x})$ é representada na Equação 1.

$$
\mu(x)=\left\{\begin{array}{c}
\frac{x-a}{b-a} \text { if } x \in[a, b] \\
\frac{c-x}{c-b} \text { if } x \in[b, c] \\
0, \text { otherwise }
\end{array}\right.
$$

Os métodos de inferência mais utilizados são o Método de Mamdani e o Método de Sugeno. Analogamente, existem diversos métodos para etapa de defuzzificação. Geralmente, utiliza-se o Método Mamdani que foi o primeiro sistema construído usando a Teoria Fuzzy e foi proposto para controlar um sistema de vapor industrial baseado na experiência humana, e assim, construir as regras do programa. Esse método é utilizado na etapa de inferência, e o método do centro de gravidade (centroid), na etapa de defuzzificação. 0 método Sugeno foi proposto por Takagi e Sugeno (1985) com objetivo de melhorar o sistema de geração de regras fuzzy nas entradas e saídas, representando, também, modelos não lineares de forma mais exata e aproximada (MAMDANI, 1973; SUGENO, 1985; TAKAGI E SUGENO, 1985; CHIN, 2014).

Na literatura consta que comparando esses dois métodos é observado que o Método Sugeno é eficiente computacionalmente, funciona bem em problemas de otimização, controladores PID e é bastante 
adequado as análises matemáticas, já o método Mamdani é mais intuitivo, tem uma aceitação muito grande e é bastante adequada a problemas de análise humana, além disso, muito mais fácil de ser manipulado que o método Sugeno.

Define-se, então, inferência como a passagem, através de regras válidas, do antecedente (SE) ao consequente (ENTÃO) de um objeto de estudo em um universo de análise. Na lógica fuzzy, essa passagem é realizada mediante a interação, determinada pelas regras de inferência, entre as variáveis linguísticas de entrada (SE), gerando um conjunto de dados de saída (ENTÃO). Essas regras são aplicadas aos conjuntos fuzzy através das variáveis linguísticas e são construídas mediante a operação entre os conjuntos. 0 input, ou condição, e output, ou consequência, de um sistema fuzzy são associados por regras com funções de pertinência ou intervalos numéricos [0,1] (ZADEH, 1965; LOBATO et al, 2015).

0 sistema criado neste trabalho foi baseado em aproximadamente 30 regras correlacionadas com os valores do WQIR, criando o WQIRfuzzy considerando os graus de pertinência dos elementos diferentemente da lógica utilizada pelos demais índices. Os pesos atribuídos as regras foram iguais a 1 para que se analise a influência dos parâmetros de forma equivalente quantitativamente.

Do conjunto de dados ambientais, comumente representados na literatura, a clorofila-a, fósforo e nitrogênio são indicativos do processo de eutrofização, pois níveis altos de nitrogênio e fósforo demonstram que há presença de bastante nutriente no meio aquático.

$\mathrm{O}$ nitrogênio pode ser encontrado na forma amoniacal, nitrato ou nitrito. Na forma de amônia livre, o nitrogênio é tóxico a peixes e outros animais que estejam presentes no corpo hídrico. Além disso, este serve como nutriente para algas e influência de forma direta na demanda de oxigênio dissolvido. Em relação as concentrações de fósforo, sabe-se que este influencia no aumento da produção de plâncton que é fonte de alimento de peixes, o que aumenta a população deste causando desequilíbrio no ecossistema (CHIN, 2014; MENDONÇA, 2014).

O oxigênio dissolvido (DO) é outro parâmetro importante no IQA. Quanto mais substâncias oxidáveis há em um corpo d'água resultam no consumo de oxigênio e na consequente diminuição de DO. Neste contexto, níveis baixos de DO podem causar diminuição de reprodução dos peixes e sua consequente morte. Já a clorofila-a é utilizada como indicadora da biomassa fitoplanctônica em ambientes aquáticos por se tratar de um pigmento encontrado em todos os grupos de vegetais e outros organismos autótrofos. A sua concentração ajuda na interpretação de resultados de análises físico-químicas, além de ser indicadora do estado fisiológico do fitoplâncton e do grau de eutrofização de um ambiente aquático (MENDONÇA, 2014).

As faixas limitantes desses índices foram seguidas segundo resolução CONAMA no 357/05 para águas de reservatórios. $O$ índice de OD deve estar em uma concentração de pelo menos $5 \mathrm{mg} / \mathrm{L}$, a clorofila-a possui valores limites de $30 \mu \mathrm{g} \mathrm{L}-1$, fósforo deve ser tolerado até uma concentração de até $0,05 \mathrm{mg}$ L-1 e o nitrogênio total entre 0,16 e $0,25 \mathrm{mg}$ L-1. Os valores médios dessas variáveis no reservatório da Macela estão muito acima do permitido, conforme ilustrado na Tabela 2, na qual são apresentados os parâmetros médios analisados na coleta dos dados do açude.

\section{MATERIAIS E MÉTODOS}

\section{1 ÁREA DE ESTUDO}

O reservatório da Macela, localizado na cidade de Itabaiana-SE, foi construído no período de 1953 a 1957 pelo barramento do riacho Fuzil. Esse reservatório tem uma capacidade de aproximadamente de 2,7x106 m3, ocupando uma área de $14 \mathrm{~km} 2$ e foi projetado para fornecer água para irrigação de 156 hectares. 
Figura 1 - Localização do reservatório da Macela, Itabaiana-SE

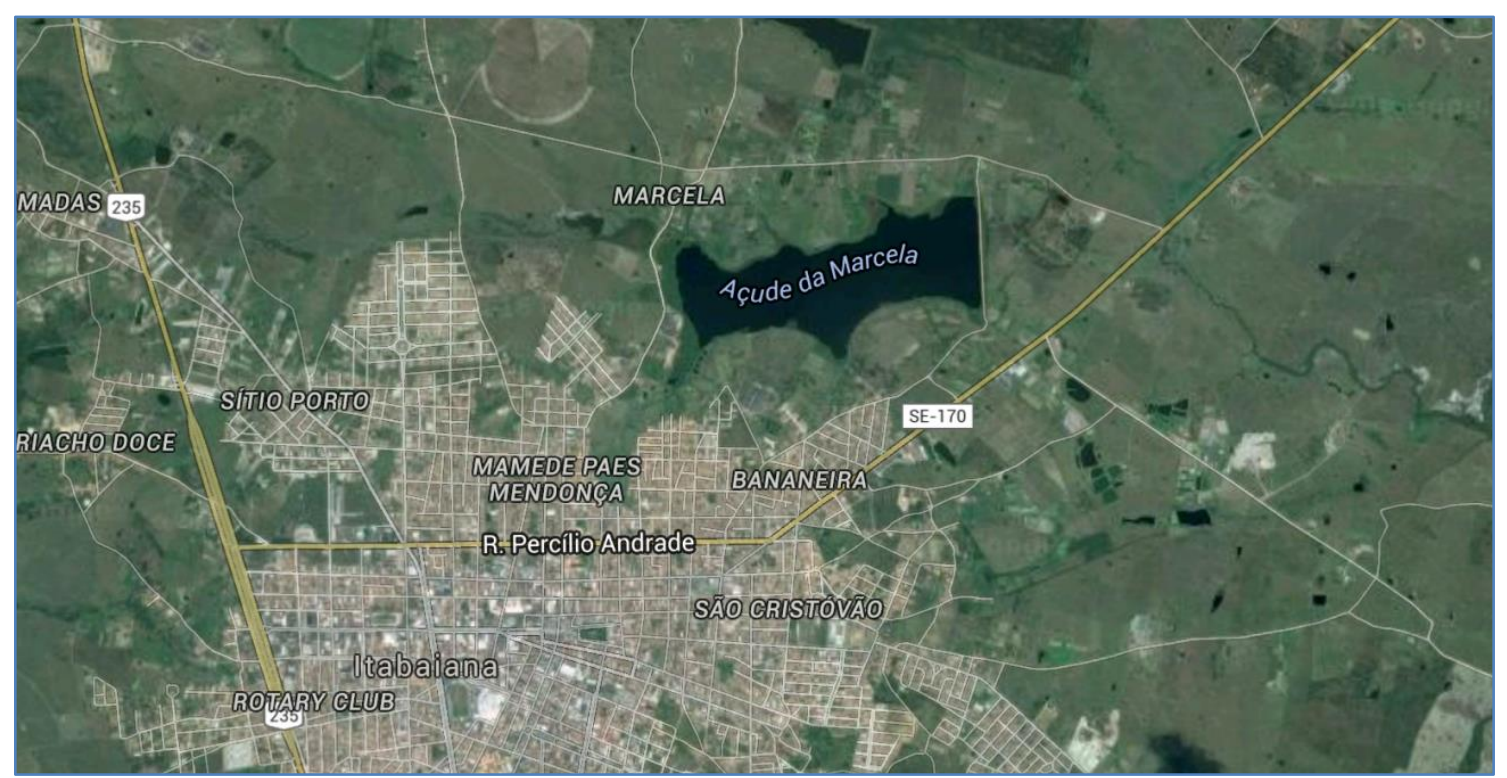

Fonte: Google Earth (2016)

\subsection{PROCEDIMENTOS METODOLÓGICOS}

Os dados ambientais utilizados neste trabalho foram determinados segundo metodologia descrita pelo APHA, Standard Methods for the Examination of Water and Wastewater e fornecidos pelo LQA/DQI/UFS. A Tabela 2 mostra os valores médios dos parâmetros ambientais utilizados na análise fuzzy da qualidade da água.

Tabela 2: Parâmetros avaliados no Açude da Macela (MENDONÇA, 2014)

\begin{tabular}{c|c|c} 
Parâmetro & Média & Desvio Padrão \\
\hline Condutividade $(\mathrm{mS} \mathrm{cm}-1)$ & 1,67 & 0,63 \\
\hline Cor (Pt-Co) & 21,48 & 13,28 \\
\hline $\mathrm{pH}$ & 8,56 & 0,39 \\
\hline Sólidos Totais (mg L-1) & $1.058,02$ & 339,64 \\
\hline Sólidos Suspensos (mg L-1) & 23,06 & 24,79 \\
\hline Oxigênio Dissolvido (mg L-1) & 5,32 & 2,85 \\
\hline N-NH4 ( $\mu$ g L-1) & 48,19 & 39,66 \\
\hline N-NO2 ( $\mu$ g L-1) & 146,92 & 146,31 \\
\hline N-NO3 ( $\mu$ g L-1) & $1.255,96$ & 615,88 \\
\hline P-PO4 (mg L-1) & 415,14 & 200,3 \\
\hline Clorofila-a ( $\mu$ g L-1) & 59,28 & 63,2 \\
\hline Temperatura Água (oC) & 28,23 & 1,82 \\
\hline
\end{tabular}

\section{RESULTADOS E DISCUSSÃO}

Para a avaliação do IQARfuzzy foram utilizados os 4 parâmetros já citados, Nitrogênio Total, Fósforo Total, OD e clorofila-a. Além disso, o índice obtido foi comparado com os índices IAP e IQARm obtidos por Mendonça (2014). Os índices obtidos no trabalho de Mendonca (2014) serviram para estabelecer a validade do IQARfuzzy obtido. Para obtenção do IQARfuzzy foram usadas as funções de pertinência mostradas na Figura 2. As variáveis de entrada utilizadas foram OD, clorofila-a, Nitrogênio Total e Fósforo. 
Figura 2: Funções de pertinência e seu WQIR como output

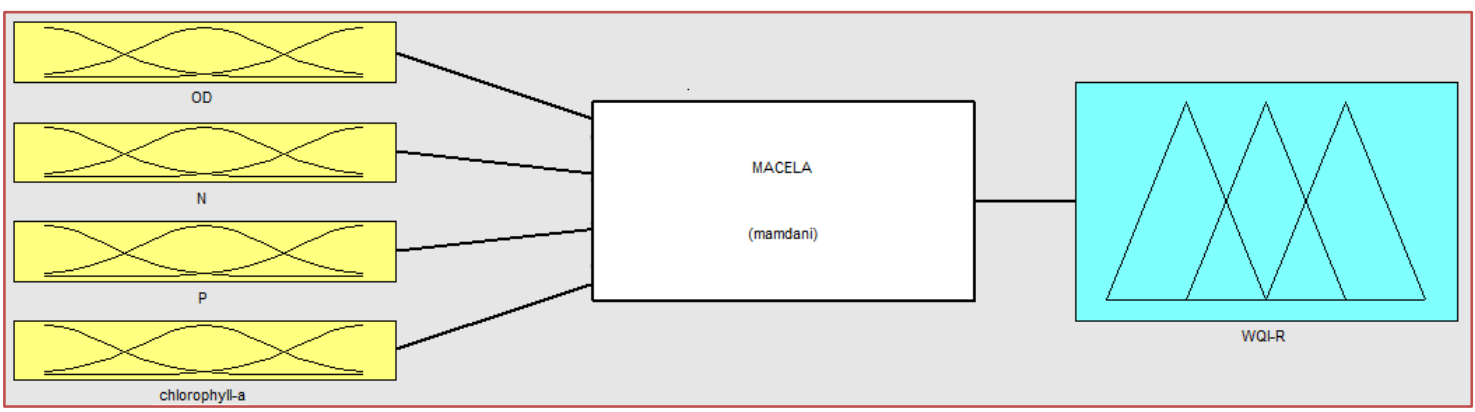

A Figura 3 mostra a análise comparativa estabelecida para caracterizar o ambiente em estudo. Foi colocado, nesta figura, os valores de IQARfuzzy das amostras coletadas na superfície, no meio e no fundo do reservatório, bem como IQARfuzzy calculado utilizando parâmetros limites do CONAMA. Ao reproduzir esses valores médios dos parâmetros do reservatório de Macela observa-se que o programa desenvolvido resultou um IQARfuzzy igual a 6,3, o que significa que este reservatório está em condições de extremamente poluído.

Outro valor em destaque é o do valor determinado pelo IAP, apresentado na Tabela 1, a partir do qual o corpo d'água é considerado extremamente poluído. Observa-se que amostras coletadas na superfície e no meio do reservatório tendem a ter valores locais de IQARfuzzy com alta poluição, e no fundo com valores menores. Isso acontece, pois, na superfície a concentração desses parâmetros é maior e tende a diminuir conforme mais profunda for feita a coleta. Um exemplo disso é a concentração de clorofila-a que é bastante reduzida conforme o ponto da coleta da amostra.

Figura 3 - Análise do WQIRfuzzy para o reservatório da Macela

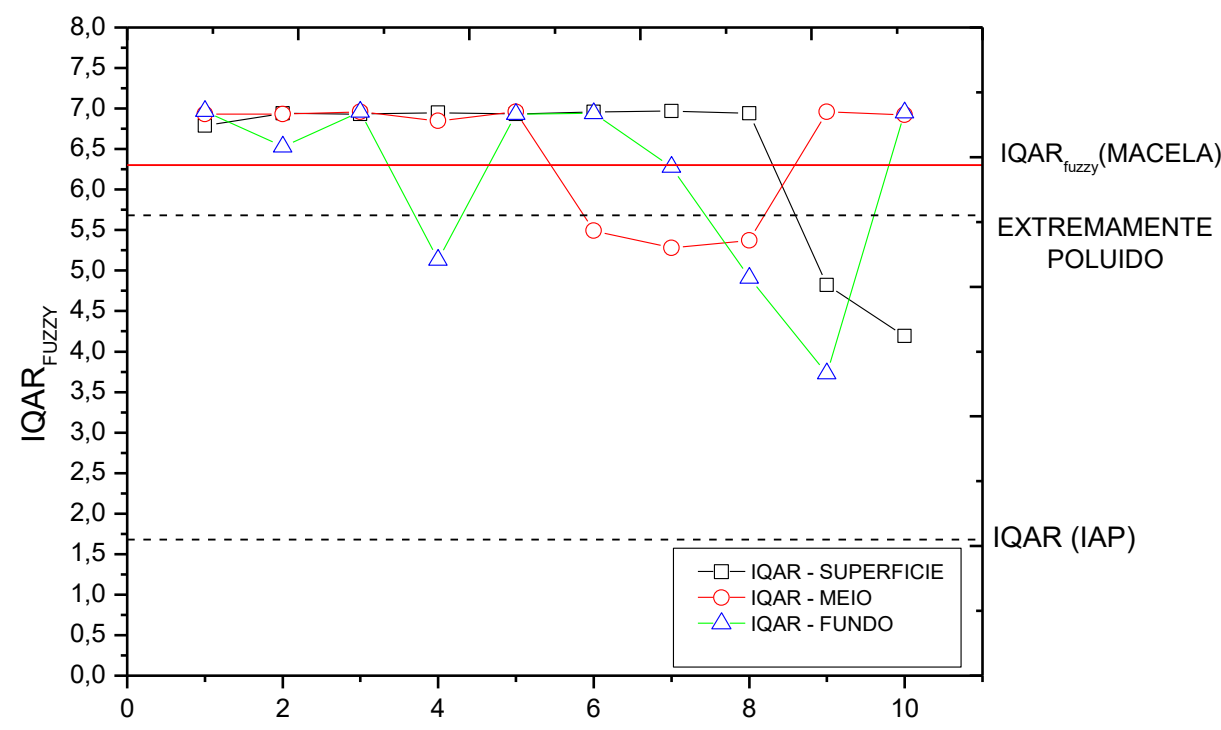

Os valores médios dos parâmetros, observados para este trabalho, apresentados na Tabela 2 permite o estabelecimento de uma comparação com os cálculos de IQAR e IQAR-m obtidos para esse mesmo açude conforme calculado por (MENDONÇA et al 2014). A comparação dos índices é apresentada na Tabela 3. 
Tabela 3: Índices de Qualidade de Água referentes ao Açude da Macela.

\begin{tabular}{c|c|c}
\multicolumn{1}{c}{ Índice } & Açude da Macela & Classe Equivalente \\
WQIR (IAP) & 6,00 & Extremamente poluído \\
\hline WQIR-m & 4,61 & Muito poluído \\
\hline WQIRfuzzy & 6,3 & Extremamente poluído \\
\hline
\end{tabular}

Desta maneira, observou-se que os três métodos apresentam a mesma conclusão sobre o reservatório da Macela que possui um nível de eutrofização elevado e está extremamente poluído. Faz-se notar que embora o método fuzzy aplicado levou em consideração apenas quatro das variáveis quantificadas, ele é bastante representativo apresentado respostas semelhantes aos demais com uso de todas variáveis, pois, os parâmetros escolhidos são considerados cruciais para a avaliação de um reservatório.

\section{CONCLUSÃo}

Neste trabalho foi avaliada a qualidade da água do reservatório da Macela, situado em Itabaiana, Sergipe. A proposta foi obter um índice utilizando a lógica fuzzy para que fosse comparado como dois outros índices da literatura. Neste contexto, os valores apresentados pelo IQARfuzzy e os índices IQAR (IAP) e IQAR-m apresentados na literatura convergiram para valores que demonstraram o elevado nível de poluição do corpo avaliado.

Esses resultados sintetizam que o açude da Macela se encontra em um nível elevado de poluição. Além disso, é importante ressaltar que o índice de qualidade de água pode ser determinado utilizando diferentes estratégias numéricas.

No entanto, por sua analogia com o conhecimento de especialistas e praticidade, a lógica fuzzy pode ser considerada um meio preciso e eficaz de determinação desses índices de qualidade. É importante, também, comentar que devido ao alto nível de degradação do açude, é esperado que uma política de gestão ambiental por parte do governo seja proposta ou implementa efetivamente no reservatório da Macela, Itabaiana, Sergipe, Brazil. Dentre algumas estratégias de gestão, ressalta-se que um programa de conscientização da população que vive nas proximidades e que depende deste reservatório, afim, de evitar maiores impactos ambientais e, consequentemente, danos a suas vidas, já que este reservatório é fonte de sobrevivência econômica do município.

\section{AGRADECIMENTOS}

Ao LQA/UFS pela concessão dos dados utilizados e à FAPITEC pela concessão dos recursos financeiros utilizados no desenvolvimento deste trabalho.

\section{REFERÊNCIAS}

[1] ABBASI, T.; ABBASI, S. A. (2012). Water Quality Indices. 1aㅡ edição. Elsevier, 384p.

[2] CABAnillas, J., GinebredA, A., GUILlen, D., MARTINEZ, E., BARCELO, D., MORAGAS, L., ROBUSTE, J., DARBRA, R.M., (2012). Fuzzy logic based risk assessment of effluents from wastewater treatment plants. Sci. Total Environ. $439,202-210$.

[3] CHIN, D. A. (2013). Water-Quality Engineering in Natural Systems: Fate and Transport Processes in the Water Environment. New Jersey: WILEY, 471p.

[4] CONAMA, “Conselho Nacional do Meio Ambiente, Resolução no 357, 2005,” (2014) Disponível em: <http://www,mma,gov,br/port/conama/>, Acesso em 12 jun, 2014.

[5] GABRIEL, C. P. C.; Aplicaçao da Logica Fuzzy para Avaliaçao do Faturamento do Consumo de Energia Eletrica e Demanda de uma Empresa de Avicultura de Postura. Tese apresentada à Faculdade de Ciências Agronômicas da UNESP - Campus de Botucatu,p. 108, 2008.

[6] GHARIBI, H; MAHVI, A.H.; NABIZADEH, R.; ARABALIBEIK, H.; YUNESIAN, M.; SOWLAT, M.H. (2012). A novel approach in water quality assessment based on fuzzy logic. Journal of Environmental Management, v. 112, p. 8795. 
[7] LERMONTOV, A.; YOKOYAMA, L.; LERMONTOV, M.; MACHADO, M.A.S. (2009). River quality analysis using fuzzy water quality index: Ribeira do Iguape river watershed, Brazil. Ecological Indicators, v. 9, n. 6, p. 1188-1197.

[8] LOBATO, T. da C.;HAUSER-DAVIS, R.A.; OLIVEIRA, T. F.; MACIEL, M.C.; TAVARES, M.R.M.; SILVEIRA, A.M.; SARAIVA, A.C.F. (2015). Categorization of the trophic status of a hydroelectric power plant reservoir in the Brazilian Amazon by statistical analyses and fuzzy approaches. Science of the Total Environment journal. v. c, p. 613-620.

[9] MAMDANI, E. H. (1973). Aplications of fuzzy algorithms for control of simple dynamic plant. Proc. IEEE 121, vol. 12, p. $1585-1588$.

[10] MCKONE, T.E., DESHPANDE, A.W., (2005). Can fuzzy logic bring complex environmental problems into focus. Environmental Science and Technology. 39, 42A-47A.

[11] MENDONÇA, M. C. S. (2014). Avaliação do processo de eutrofização dos reservatórios açude da macela e rio Jacarecica através do índice de qualidade da água para reservatórios. Trabalho de Conclusão de Curso, Química Industrial. DEQ/UFS.

[12] OCAMPO-DUQUE, W.; SCHUHMACHER, M.; DOMINGO, J. L. (2007). A neural-fuzzy approach to classify the ecological status in surface waters. Environmental Pollution, v. 148, n. 2, p. 634-641.

[13] SCANNAPIECO, D. ; NADDEO, V.; ZARRA, T; BELGIORNO, V. (2012). River water quality assessment: A comparison of binary- and fuzzy logic-based approaches. Ecological Engineering, v. 47, p. 132-140.

[14] SUGENO, M. (1985). An introductory survey of fuzzy control. Information Sciences. 36, p. 59-83.

[15] TAKAGI, T.; SUGENO, M. (1985). Fuzzy Identification of Systems and Its Applications to Modeling and Control. $\mathrm{n}$. 1, p. 116-132, 1985.

[16] ZADEH, L. A. (1965). Fuzzy sets. IEEE Infromatics and Control, v. 8, p. 338-353. 


\title{
Capítulo 8
}

\section{Caracterização da matéria orgânica dissolvida presente nas águas superficiais dos rios São Francisco e Jacaré utilizando fluorescência molecular}

\author{
Roseane dos Santos Nascimento \\ Jeferson Alves de Alcântara \\ João Marcos de Jesus Sales \\ Igor Santos Silva \\ Silvânio Silvério Lopes da Costa \\ Adnívia Santos Costa Monteiro
}

Resumo: 0 estudo da matéria orgânica dissolvida (MOD) é fundamental para o entendimento dos fenômenos de origem autóctone e/ou alóctone que um corpo hídrico está sujeito. Sendo assim, este trabalho teve como objetivo, a caracterização da qualidade e fontes da MOD presente nas águas superficiais dos rios São Francisco (RSF) e Jacaré (RJ) localizados na região do baixo São Francisco, Estado de Sergipe, por meio de técnicas de custo reduzido como a UV-Vis (Ultravioleta-Visível) e a fluorescência molecular (FM). Para isso, sete pontos foram estrategicamente selecionados levando em consideração o uso e ocupação do solo. As coletas foram realizadas nos períodos chuvoso (julho/18) e seco (Dezembro/18) e em todas as amostras foi feita a quantificação de carbono orgânico dissolvido (COD), medidas de absorbância em 254 e $436 \mathrm{~nm}$ e obtenção do espectro de fluorescência e por fim, foi aplicado ao conjunto de dados a análise estatística multivariada (AEM). Os resultados obtidos revelaram a diferença significativa entre as amostras coletadas no RSF e RJ em relação à quantidade e origem da MOD. Além disso, foi possível verificar que há influência da sazonalidade e do processo de urbanização sobre a composição da MOD destes rios. Os resultados de COD das amostras do RSF mostraram que as maiores concentrações (P1-14,60; P2-18,10; P3-15,60; P4-21,80 e P5-16,90 mg L-1) foram encontradas no período seco, já as amostras do RJ apresentaram os maiores valores (P6 41,79 e P7- 56,70 mg L-1) no período chuvoso. Os resultados das medidas de absorbância e de fluorescência também apresentaram dois perfis diferentes, entre as amostras. A MOD presente no RSF apresentou predominantemente compostos semelhante a proteínas relacionadas com a atividade microbiana primária, considerada de origem autóctone, enquanto que a MOD do RJ apresentou componentes do tipo triptofano, presente em efluentes domésticos e agrícolas e do tipo substâncias húmicas que representam a origem alóctone natural da MOD. A AEM corroborou com todas essas observações. Dessa maneira, este conjunto de resultados apontaram a eficácia dos métodos utilizados ao identificar a influência das atividades antrópicas e de uso e ocupação do solo nas regiões analisadas, sendo importante para auxílio na caracterização dos corpos hídricos.

Palavras-chave: análise hierárquica de agrupamentos, ultravioleta-visível, carbono orgânico dissolvido. 


\section{INTRODUÇÃO}

Os rios sempre estiveram no centro do desenvolvimento das civilizações, contribuindo para a expansão demográfica e industrial, se tornando vitais para a prosperidade da sociedade. Em decorrência do constante avanço populacional, os rios acabaram sofrendo interferências, provenientes, especialmente, da diversificação das atividades humanas, o que resultou, por exemplo, no comprometimento da qualidade da água (MASSOUD, 2012).

Um parâmetro importante para a avaliação de corpos hídricos, é a matéria orgânica natural (MON), onipresente em todos corpos d'água. Estudos relacionados a ambientes aquáticos devido às suas características intrínsecas, como capacidade tamponante em águas com teor alcalino $(\mathrm{pH}>7)$ (Oliveira et al., 2006) e sua influência no comportamento de poluentes orgânicos e destino dos inorgânicos como os metais, manipulando a sua mobilidade e biodisponibilidade podendo assim torná-los agentes nocivos, têm sido desenvolvidos (Hur e Lee, 2011; Xu e Guo, 2017).

Uma fração da MON, é denominada matéria orgânica dissolvida (MOD), que exerce papel fundamental para a vida aquática, por ser constituída basicamente por carbono, hidrogênio, oxigênio, nitrogênio, fósforo e enxofre, tornando-se a principal fonte de energia para os organismos presentes no ecossistema. É obtida a partir de um processo operacional de filtração por membranas de diferentes porosidades $(0,22$ a 0,45 $\mu \mathrm{m}$ ) que variam conforme o interesse do estudo (FINDLAY e PARR, 2017; XU e GUO, 2017).

A abundância da MOD pode ser expressa em termos de concentração do carbono orgânico dissolvido (COD) presente na água, pois este elemento representa cerca de $50 \%$ de sua composição, permitindo a relação entre MOD e COD. (FINDLAY e PARR, 2017; MASSICOTTE et al., 2017). A qualidade, composição e estrutura, da MOD está significativamente relacionada a sua origem no meio ambiente e pode sofrer alterações em decorrência da influência da sazonalidade e do uso e ocupação do solo (BRODER, KNORR e BIESTER, 2017; HERZSPRUNG et al., 2017).

Ainda sobre a MOD, podemos classificá-la em autóctone, proveniente da atividade microbial produzida dentro do próprio sistema aquático, como zooplâncton, fitoplâncton e algas, ou alóctone, quando provém do meio externo, podendo ser de origem terrestre em decorrência da degradação de plantas e/ou animais e levadas aos rios, lagos e oceanos, pelo processo de lixiviação e também de origem antropogênica em função da atividade humana nas proximidades dos recursos hídricos (FINDLAY e PARR, 2017; KNAPIK et al., 2014; SELBERG et al., 2011).

Os estudos de caracterização óptica da MOD têm sido realizados principalmente através das técnicas espectroscópicas de absorbância na região do ultravioleta e visível (UV-Vis) e intensidades de fluorescência molecular (IF). 0 uso frequente destas ferramentas analíticas é possível porque a MOD apresenta em sua estrutura grupos cromóforos que absorvem radiação nas regiões UV-Vis e ainda apresentam grupos fluoróforos que permite a sua identificação através de espectros de emissão/excitação obtidos pela fluorescência molecular. Além disso, o atrativo de tais técnicas se resume no seu baixo custo operacional, fácil manipulação, não destrutiva, sem tratamento prévio e pequeno volume de amostra.

Em se tratando especificamente da fluorescência molecular, esta fornece informações mais completas sobre os grupos presentes na MOD, apresentando melhor sensibilidade e elevadas frequência analítica ( 10s) (BRODER, KNORr e BIESTER, 2017; CÉSAR e AZEVEDO, 2008; GATSELOU, GIOKAS e VLESSIDIS, 2014; HELMS et al., 2008).

Nesse contexto, este estudo teve como objetivo caracterizar a matéria orgânica dissolvida presente nas águas do rio São Francisco, mais especificamente na região do baixo São Francisco, e do rio Jacaré, seu principal afluente no estado de Sergipe, utilizando as técnicas UV-Vis e IF. Os resultados poderão ser relacionados ao uso e ocupação do solo adjacente aos pontos de coletas. Vale a pena ressaltar que se trata de um estudo pioneiro nessa região específica e que estes pontos de amostragem têm sido utilizados para diferentes finalidades sociais e econômicas, como abastecimento de água para a população, fornecimento de água à agricultura irrigada, pesca, navegação, ecoturismo, geração de energia elétrica através da usina de Xingó e entre outras funcionalidades (AGUIAR NETTO e SANTANA, 2015; COSTA e AGUIAR NETTO, 2018). 


\section{MATERIAIS E MÉTODOS}

\section{1 ÁREA DE ESTUDO E AMOSTRAGEM}

As amostras de água superficiais foram coletadas no período chuvoso (Julho/2018) e no período seco (Dezembro/2018), com o intuito de avaliar a influência da sazonalidade na qualidade da água. Foram selecionados sete pontos de amostragem na região do baixo do São Francisco, Estado de Sergipe, levandose em consideração a acessibilidade e os diferentes tipos de uso e ocupação do solo nas regiões em que estão situados, conforme ilustra a Figura 1 e as suas respectivas coordenadas em projeção universal transversa de mercator (UTM) estão descritas na Tabela 1.

Dentre os sete pontos, quatro estão localizados no curso principal do Rio São Francisco, classificados como P1 - prainha situada nas proximidades da barragem de Xingó, localizada na cidade de Canindé do São Francisco; P2 - no povoado Curralinho, no município de Poço Redondo; P3 - próximo a adutora da DESO Companhia de saneamento de Sergipe, no município de Brejo Grande; e P4 - localizado na foz do Rio São Francisco, próximo ao povoado Saramem, município de Propriá. Os demais pontos de amostragem encontram-se ao longo de um dos afluentes do Rio São Francisco, o rio Jacaré que fica situado no território de Poço Redondo, sendo estes, P5- na barragem do Assentamento Jacaré - Curituba; P6 - na calha do centro de difusão, nas proximidades do Assentamento Jacaré - Curituba; e P7 - na foz do rio Jacaré, desaguando no rio São Francisco.

Tabela 1 - Estações de monitoramento no baixo curso do rio São Francisco e rio Jacaré.

\begin{tabular}{c|c|c} 
Estações & \multicolumn{2}{c}{ Coordenadas } \\
& X & 8934116 \\
P1 & 633194 & 8925087 \\
\hline P2 & 653165 & 8873285 \\
\hline P3 & 735681 & 8840926 \\
\hline P4 & 782699 & 8927866 \\
\hline P5 & 637599 & 8926218 \\
\hline P6 & 640139 & 8928110 \\
\hline
\end{tabular}

Figura 1 - Localização dos pontos de amostragem para fins de caracterização da MOD ao longo do curso do rio São Francisco.

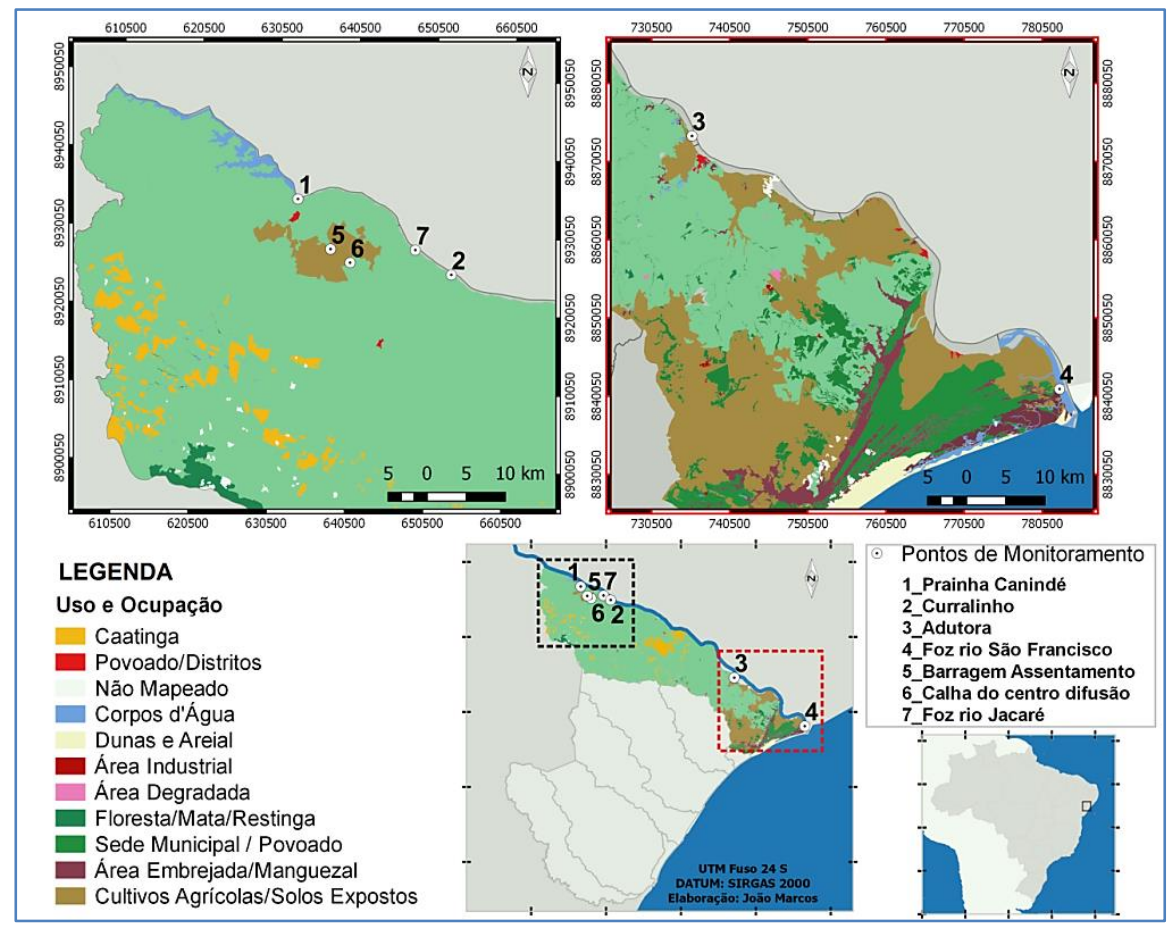

Fonte: autoria própria. 
Os procedimentos de coleta e armazenamento seguiram protocolo descrito no Standard Methods for the Examination of Water and Wastewater (APHA, 2017), em seguida, as amostras foram encaminhadas ao laboratório onde foram filtradas em membranas de $0,45 \mu \mathrm{m}$ para posterior análises. As análises de $\mathrm{pH} \mathrm{e}$ condutividade elétrica foram realizadas in situ, utilizando um medidor multiparâmetros da marca LOVIBOND, modelo SENSO DIRECT 150, previamente calibrado.

\subsection{ANÁLISES DE UV-VIS}

As análises de absorbância na região do UV-Vis foram realizadas nos comprimentos de onda $254 \mathrm{~nm}$ e 436 nm Selberg et al., (2011), utilizando um espectrofotômetro da marca FEMTO modelo 700 PLUS e cubetas de quartzo de $1 \mathrm{~cm}$. Além disso, utilizou-se água ultrapura como branco (Helms et al., 2008).

\subsection{MEDIDAS DE INTENSIDADE DE FLUORESCÊNCIA}

Os espectros de fluorescência foram obtidos utilizando um espectrofluorímetro da marca Perkin Elmer, modelo LS45, cuja fonte de excitação é oriunda de uma lâmpada de xenônio, utilizando uma cubeta de quartzo de $10 \mathrm{~cm}$. 0 intervalo de emissão e excitação para a obtenção dos espectros foi de $30 \mathrm{~nm}$ com fendas de $10 \mathrm{~nm}$ Jaffé et al., (2004) e uma varredura de 250 a $500 \mathrm{~nm}$. Os espectros foram posteriormente corrigidos com o branco analítico (Duan et al., 2015).

\subsection{DETERMINAÇÃO DO CARBONO ORGÂNICO DISSOLVIDO}

A determinação da concentração do COD foi realizada a partir da combustão das amostras a $950{ }^{\circ} \mathrm{C}$ utilizando um analisador de carbono orgânico total da marca Shimdzu modelo 5000 A. Os valores obtidos para cada amostra foram resultados da média de ao menos três injeções em termos de coeficiente de variação $(\leq 2 \%)$.

\section{RESULTADOS E DISCUSSÃo}

Os resultados obtidos a partir das determinações de COD, absorbância (254 e $436 \mathrm{~nm}$ ) e fluorescência molecular sincronizada forneceram informações relevantes em relação à quantidade e origem da matéria orgânica dissolvida presente nas águas dos rios São Francisco (RSF) e Jacaré (RJ) e permitiram ainda, inferir sobre a influência da sazonalidade e do processo de urbanização sobre a composição da matéria orgânica destes rios. Vale ressaltar ainda, que todas as análises foram realizadas no pH e condutividade natural das amostras e na temperatura ambiente.

As amostras apresentaram valores de $\mathrm{pH}$ que estiveram próximos da neutralidade e dentro da faixa recomendada pela legislação brasileira (CONAMA 357/2005) que é de 6 a 9. Os resultados de pH encontrados nas amostras do rio São Francisco variaram de 8,0 a 8,8 no período chuvoso (C) e entre 7,2 e 8,2 no período seco (S), já nas amostras do rio Jacaré os valores variaram de 7,5 a 9,0 e entre 7,7 e 8,2 para os períodos chuvosos e secos, respectivamente, sendo observado menores valores no período seco. Estes resultados nos permitem inferir que essas águas apresentam características alcalino-bicarbonatada, sendo que a alcalinidade nestas amostras pode ser devida apenas à presença de íons bicarbonato (MORGANO et al., 2002).

A condutividade elétrica (CE) é um parâmetro diretamente proporcional a quantidade de íons dissolvidos na água, (Souza, et al., 2010) segundo a CETESB, valores acima de $100 \mu \mathrm{S} \mathrm{cm}-1$ são tratados como possíveis indicadores de ambientes impactados (CESTESB, 2011). Os resultados de condutividade, Tabela 2, revelaram que as águas dos rios São Francisco P4 (Foz RSF) e Jacaré P6 (Centro de Difusão) e P7 (Foz

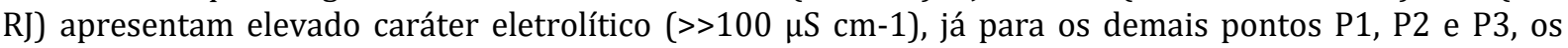
valores estiveram $\leq 100 \mu \mathrm{S} \mathrm{cm}-1$. Além disso, foi possível observar que no período chuvoso para a maioria das amostras estudadas, houve um acréscimo no valor da condutividade elétrica, em função do escoamento superficial que carrearam íons oriundos de diversas fontes.

As fontes desses íons que contribuíram para os valores elevados observado nos sítios de amostragem P4 (C-4260 e S-2390 $\mathrm{S}$ cm-1), P6 (C-1968 e S- $2140 \mu \mathrm{S} \mathrm{cm-1)} \mathrm{e} \mathrm{P7} \mathrm{(C-2560} \mathrm{e} \mathrm{S-1420} \mathrm{\mu S} \mathrm{cm-1)} \mathrm{podem} \mathrm{estar}$ associados, ao avanço da cunha salina (presença de sais oriundos da água do mar), no P4, à lixiviação de sais proveniente das atividades de irrigação no P6, sendo possível identificar que próximo a este ponto, os solos se encontram em processo de salinização e no P7, devido provavelmente aos efluentes domésticos, já 
que neste ponto, o rio já atravessou toda a cidade de Poço Redondo trazendo consigo toda a carga de poluentes acumulada neste percurso.

Tabela 1 - Resultados de pH, CE, COD e absorbâncias das amostras de água dos rios São Francisco e Jacaré.

\begin{tabular}{|c|c|c|c|c|c|}
\hline $\begin{array}{c}\text { Pontos de } \\
\text { Amostragem }\end{array}$ & $\mathrm{pH}$ & $\begin{array}{c}\mathrm{CE} \\
(\mu \mathrm{S} / \mathrm{cm})\end{array}$ & $\begin{array}{c}\text { COD } \\
\text { (mg L-1) }\end{array}$ & $\begin{array}{l}\text { A254 } \\
(\mathrm{nm})\end{array}$ & $\begin{array}{l}\text { A436 } \\
(\mathrm{nm})\end{array}$ \\
\hline \multicolumn{6}{|l|}{ Chuvoso (C) } \\
\hline $\mathrm{P} 1 \mathrm{C}$ & 8,3 & 84,00 & 4,50 & 0,03 & 0,003 \\
\hline $\mathrm{P} 2 \mathrm{C}$ & 8,8 & 78,51 & 4,13 & 0,04 & 0,003 \\
\hline P3C & 8,5 & 78,63 & 6,38 & 0,04 & 0,004 \\
\hline $\mathrm{P} 4 \mathrm{C}$ & 8,0 & 4260 & 4,75 & 0,05 & 0,005 \\
\hline $\mathrm{P} 5 \mathrm{C}$ & 7,5 & 78,25 & 11,90 & 0,04 & 0,004 \\
\hline P6C & 8,3 & 1968 & 41,79 & 0,22 & 0,013 \\
\hline P7C & 9,0 & 2560 & 56,70 & 0,29 & 0,020 \\
\hline \multicolumn{6}{|l|}{ Seco $(S)$} \\
\hline P1S & 7,5 & 107,60 & 14,60 & 0,04 & - \\
\hline $\mathrm{P} 2 \mathrm{~S}$ & 7,2 & 69,70 & 18,10 & 0,05 & 0,002 \\
\hline P3S & 7,6 & 75,43 & 15,60 & 0,31 & 0,02 \\
\hline $\mathrm{P} 4 \mathrm{~S}$ & 8,2 & 2390 & 21,80 & 1,09 & 0,72 \\
\hline P5S & 7,7 & 68,71 & 16,90 & 0,06 & 0,005 \\
\hline P6S & 8,2 & 2140 & 18,40 & 1,23 & 0,73 \\
\hline P7S & 8,1 & 1420 & 23,30 & 0,31 & 0,02 \\
\hline
\end{tabular}

0 carbono orgânico dissolvido (COD) representa uma medida quantitativa da matéria orgânica total dissolvida na água, e em águas superficiais os valores do COD podem variar de 1 a 20 mg L-1, podendo exceder esse valor em ambientes que recebem despejos urbanos e/ou industriais, ou em águas coloridas devido a presença de matéria orgânica natural (CHAPMAM, 1992).

A Figura 2 mostra a variação das concentrações do COD medido nas águas dos rios São Francisco e Jacaré nos períodos chuvoso (C-Julho) e seco (S-Dezembro). As maiores concentrações foram encontradas no período seco, para as amostras coletadas em P1 (C- 4,50 e S- 14,60 mg L-1), P2 (C- 4,13e S-18,10 mg L-1), P3 (C-6,38 e S-15,60mg L-1), P4 (C-4,75 e S-21,80 mg L-1) e P5 (C-11,90e S-16,90 mg L-1) evidenciando que nesses ambientes, o COD é diluído com a água da chuva. Já as amostras P6 (C- 41,79 e S- 18,40 mg L-1) e P7 (C- 56,70 e S- 23,30 mg L-1) apresentaram os maiores valores no período chuvoso, permitindo identificar um padrão de variação sazonal para o COD nos rios estudados. Maiores concentrações de COD no período chuvoso revela a contribuição da lixiviação dos solos e plantas para os rios através das chuvas, além de evidenciar também a possível contribuição significativa de fontes difusas para a MOD dos rios (COSTA, 2011). No Brasil, não existe uma legislação que define valores máximos permitidos para o COD.

Em 2011, estudo realizado por Costa (2011) na Bacia Hidrográfica do rio São Francisco (BHSF), sem considerar o rio Jacaré, mostrou que a média dos resultados de COD encontrados foi de 14,62 mg L-1, valor próximo a média encontrada neste trabalho que foi de 11,23 mg L-1. A média geral (incluindo os dados do RJ) de COD encontrada neste trabalho, 18,49 mg L-1 para a BHSF, são superiores aos encontrados na Planície de inundação do alto rio do Paraná (4,40 mg L-1- AZEVEDO, 2008) e na Bacia Hidrográfica do rio Iguaçu-PR (10,39 mg L-1- SCHEFFER, 2006), por exemplo. 
Figura 2 - Variação da média das concentrações do COD medido nas águas dos rios São Francisco e Jacaré nos períodos chuvoso (azul) e seco (preto).

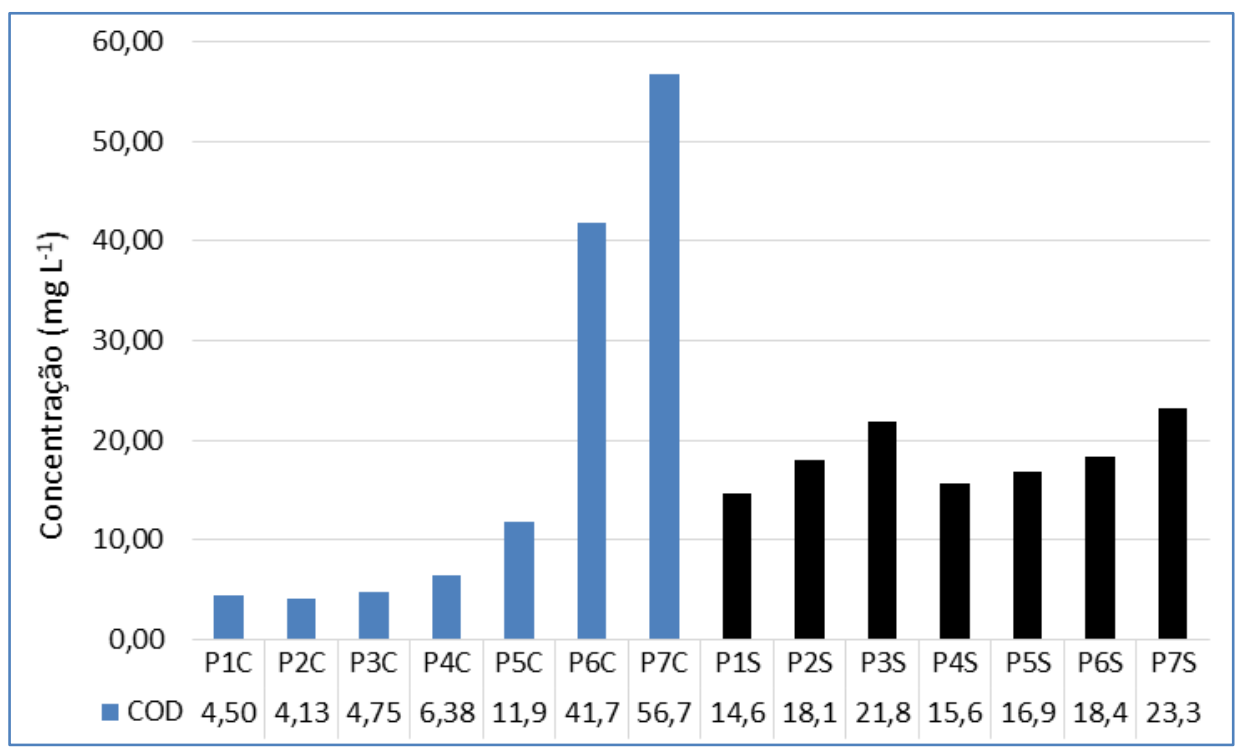

Na avaliação qualitativa da MOD presente nas águas dos rios SF e RJ foram utilizados os resultados das medidas de absorbância (A) e da intensidade de fluorescência (IF). Os espectros de absorção molecular são geralmente formados pela sobreposição de várias bandas, sem máximos definidos, apresentando absorção decrescente com o aumento do comprimento de onda (SANTOS, 2006), comportamento que pode ser observado na Figura 3 que mostra o espectro de absorção molecular obtido para as amostras coletadas no período chuvoso, o mesmo perfil de espectro foi encontrado no período seco.

Figura 3 - Espectro de absorção molecular das águas dos rios São Francisco e Jacaré coletadas no período chuvoso.

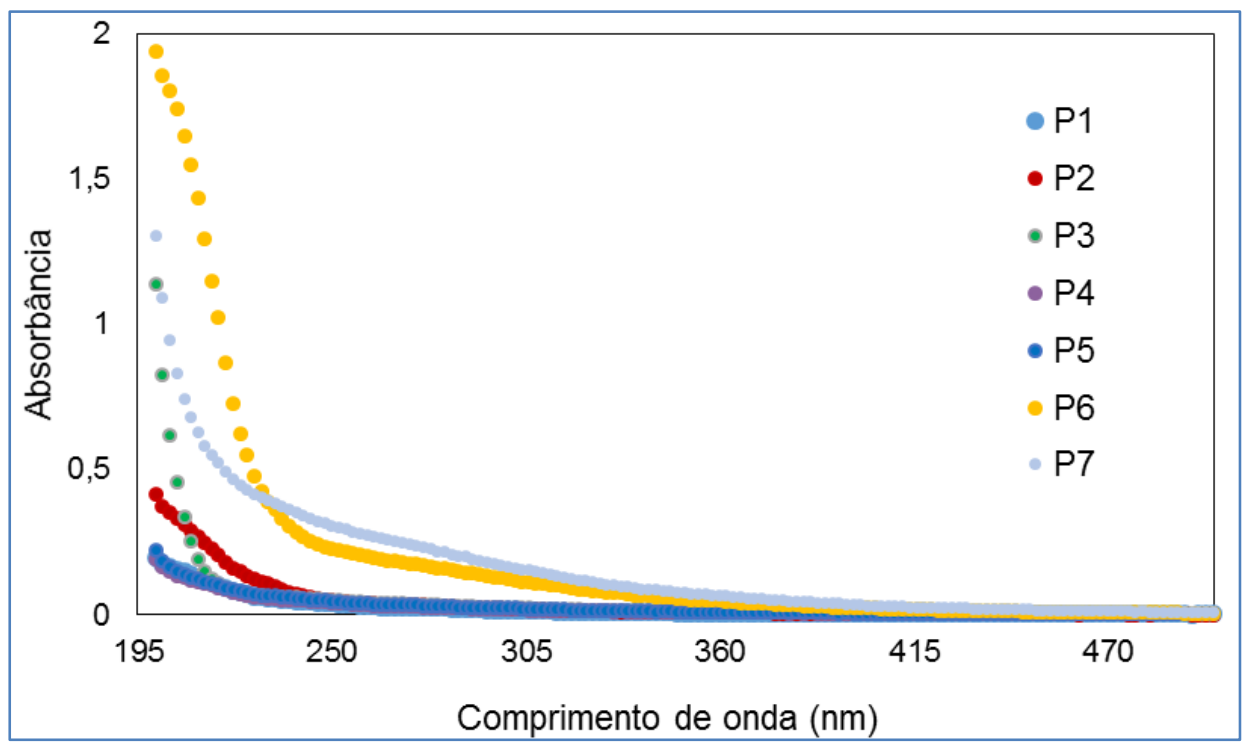

Neste trabalho as absorbâncias foram medidas nos comprimentos de onda $254 \mathrm{~nm}$ e $436 \mathrm{~nm}$ (ver Tabela 1). Elevados valores $(>0,1)$ de absorbância em $254 \mathrm{~nm}$, evidencia maior predominância da matéria orgânica rica em componentes aromáticos, tipo substâncias húmicas aquáticas (SHA), que podem ser de origem terrestre (alóctone) e derivada da decomposição de plantas (JAFFÉ et al., 2004; MONTEIRO et al., 2016). 
De acordo com os resultados obtidos para $A_{254 m}$ pode-se observar que as amostras do rio São Francisco P1, P2, P3, P4 e P5 no período chuvoso apresentaram baixos valores, 0,03, 0,04, 0,04, 0,05, 0,04, respectivamente, evidenciando que além das baixas concentrações de COD, nesse período, a matéria orgânica dessas amostras está associada à produção interna gerada predominantemente a partir da produção primária microbial, ou seja, autóctone (JAFFÉ et al., 2004). Para o mesmo período, as amostras P6 e P7 apresentaram valores altos 0,22 e 0,29, respectivamente, indicando que a sua MOD é predominantemente tipo substâncias húmicas (MCDONALD et al., 2004). Outra característica peculiar desses ambientes (P6 e P7) é a coloração amarela, a qual pode estar associada à presença das SHA.

Este comprimento de onda pode ser utilizado também para o monitoramento de concentrações do COD, pois geralmente, apresenta forte correlação com a absorbância à $254 \mathrm{~nm}$, esta relação fornece uma estimativa da abundância de espécies que absorvem nesse comprimento de onda, tornando a técnica de UV-Vis ainda mais atrativa para tipo de estudo (KORSHIN, 1997; MCDONALD et al., 2004; COSTA, 2011).

A Figura 4 mostra a relação entre $A_{254 n m}$ versus o COD para o período chuvoso (a esquerda) e para o período seco (a direita). Observando a Figura pode-se constatar que no período chuvoso a relação foi linear com $R=0,98$, evidenciando que a MOD nesse período é predominantemente natural e de origem alóctone nos pontos de maior abundância das SHA (P6 e P7) e de origem autóctone nos demais pontos, onde os resultados de $A_{254 \mathrm{~nm}}$ indicaram pouca abundância das SHA. Já no período seco, a relação não linear $(\mathrm{R}=0,1833)$ obtida entre $A_{254 n m}$ e o conteúdo do COD indicam que neste período pode ocorrer de maneira mais significativa o aporte de fontes antropogênicas além das fontes naturais (alóctone e autóctone) que exercem um efeito significativo sobre a MOD das amostras estudadas.

Figura 4 - Correlação entre o COD e a absorbância 254 nm.

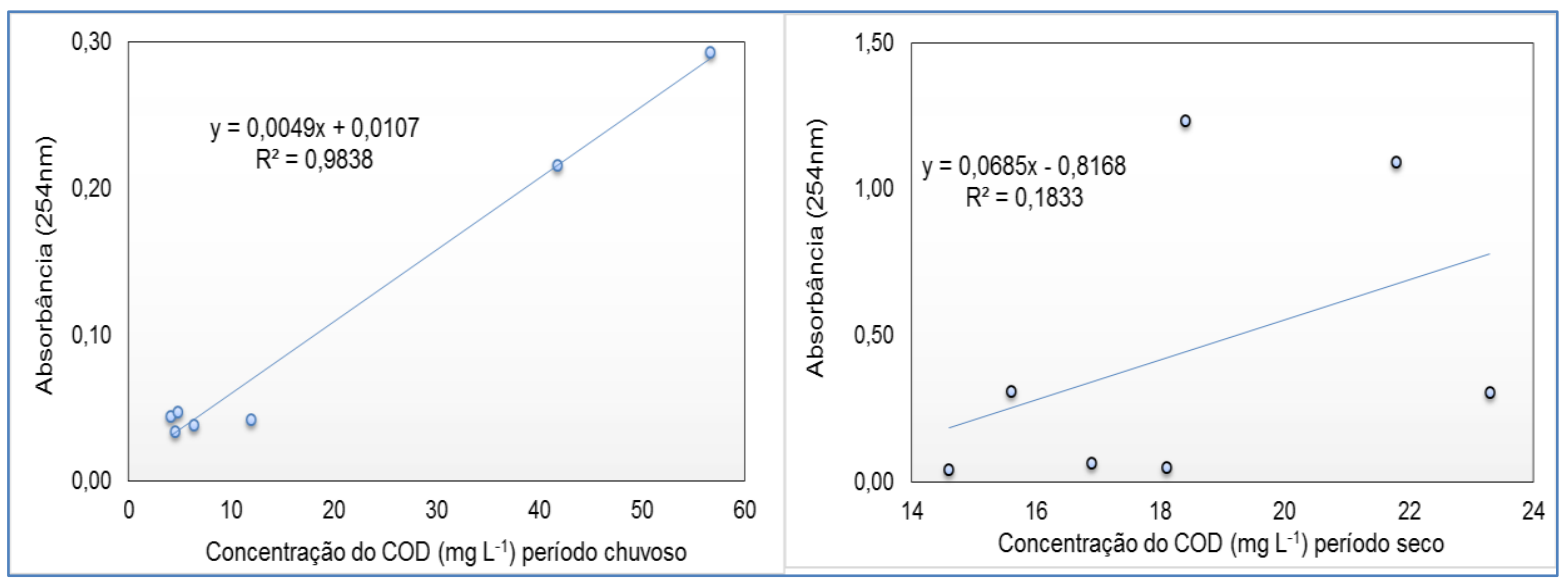

Os espectros sincronizados de fluorescência obtidos para as amostras de água dos rios são Francisco e Jacaré apresentaram dois perfis diferentes, como pode ser observado nas Figuras 5 (período chuvoso) e 6 (período seco).

0 primeiro perfil foi obtido para as amostras do P1, P2 e P5 em ambos os períodos de amostragem, onde foi observada a presença predominante do pico I, que pode ter o seu máximo entre as regiões de 280 a 310 $\mathrm{nm}$ do espectro. A literatura especializada tem atribuído o surgimento do pico à presença de aminoácidos aromáticos, compostos estruturalmente semelhante a proteínas relacionadas com a atividade microbiana primária, considerada de origem autóctone, sendo os produtores primários, tanto o fitoplâncton quanto as macrófitas aquáticas, suas principais fontes (PEURAVOURI et al., 2002; JAFFÉ et al., 2004; ARGUELHO et al., 2017; HERZSPRUNGET al., 2017). Estes resultados corroboram com os dados de $A_{254 n m}$.

O segundo perfil foi obtido para as amostras coletadas nos pontos P4S, P6C, P6S, P7C e P7S nos quais foi observada a presença de quatro picos, pico I, II, III e IV. O pico II que variou de 300 - 365 nm esteve presente nos P3C e no P4S, P6S e P7S, revela a presença de compostos que podem apresentar em sua estrutura dois a quatro anéis aromáticos, tipo o triptofano, que pode ser encontrado em águas residuais incluindo os efluentes de esgotos e os resíduos agrícolas, dessa forma, o pico II é indicativo de aporte antropogênico (JAFFÉ et al., 2004; HUDSON et al. 2007; ARGUELHO et al., 2017). O P3C se comportou de forma isolada, sendo encontrado em seu espectro apenas o pico II, indicando que no período chuvoso, 
recebeu um aporte extra de conteúdo orgânico de fonte difusa já no período seco apresentou apenas o pico I.

Figura 5 - Espectro de fluorescência molecular sincronizado para água da superfície dos rios São Francisco e Jacaré, coletada no período chuvoso (julho de 2018).

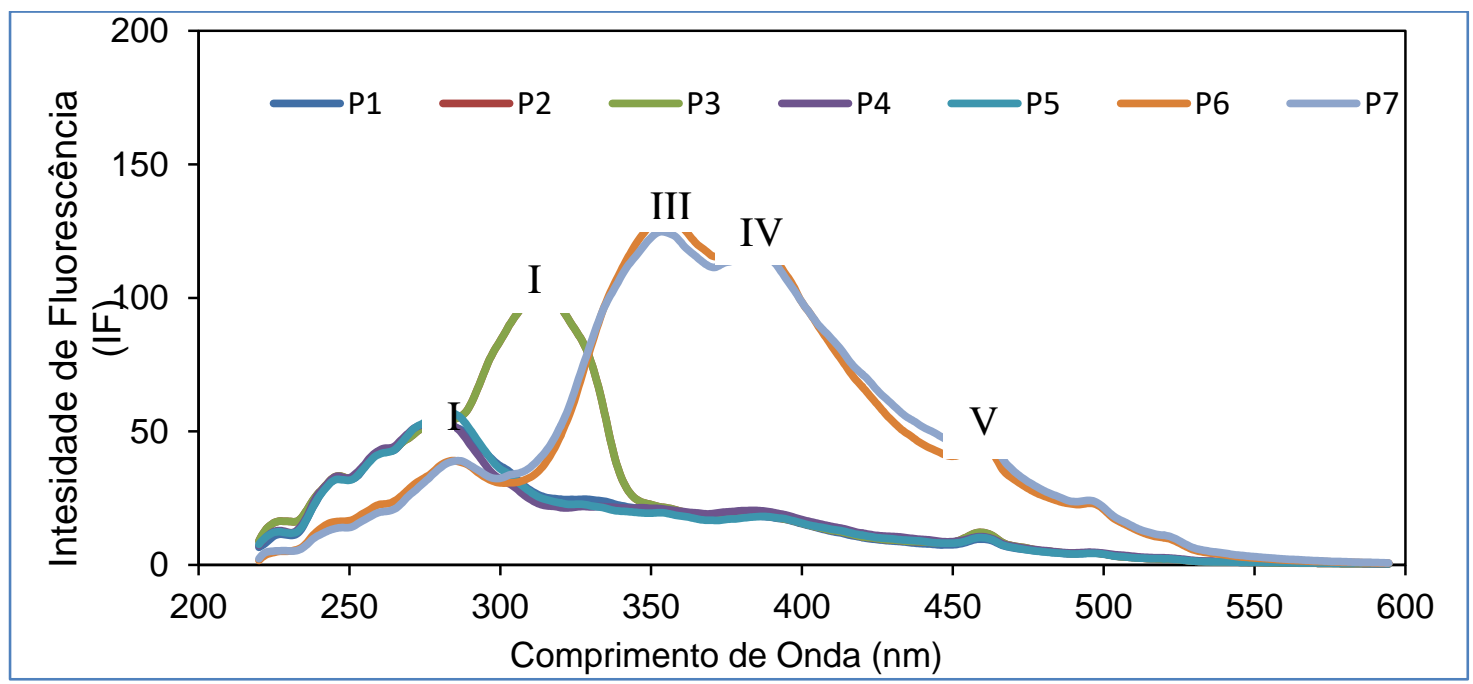

Figura 6 - Espectro de fluorescência molecular sincronizado para água da superfície dos rios São Francisco e Jacaré, coletada no período seco (dezembro de 2018).

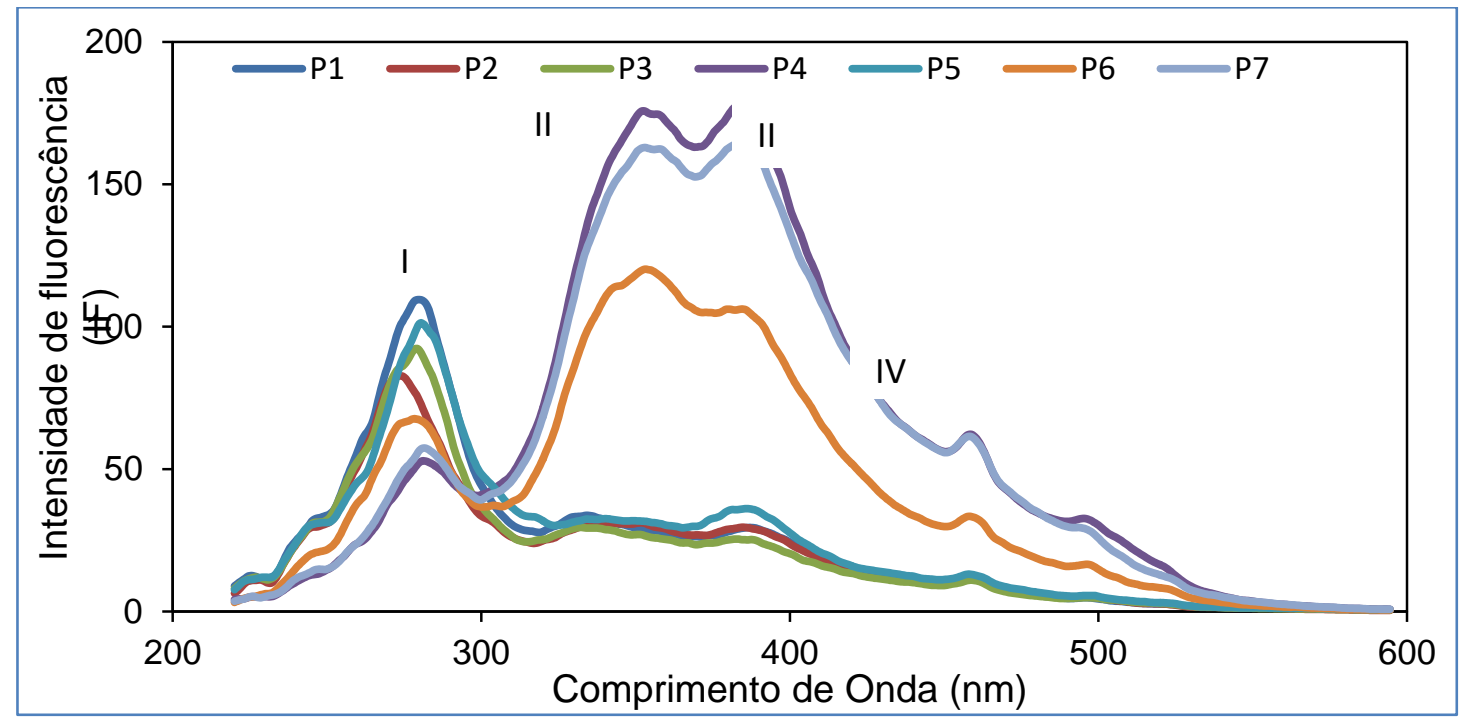

Dessa forma, fica evidente que o avanço da urbanização e consequentemente o mau uso e ocupação do solo nas proximidades desses rios já começam a impactar de maneira negativa a qualidade da MOD presente nesses rios.

O pico III (370-420nm) observado nos espectros, com valores elevados de IF, representa a classe de fluoróforos, que pode caracterizar o ácido fúlvico, uma das frações que compõem a substâncias húmicas (derivados de plantas e resíduos de árvores que contém uma maior concentração de compostos fenólicos e ligno-derivados) (JAFFÉ et al., GUSSO, 2008; ARGUELHO et al., 2017).

O pico IV onde o máximo de intensidade está centrado em torno de 450 - 460 e reflete a influência dos ácidos húmicos, outra fração da SHA, foi verificada nos espectros, porém com uma baixa contribuição, pois, apresentou baixas intensidades de fluorescência para todos os rios estudados (JAFFÉ et al., 2004; GUSSO, 2008; ARGUELHO et al., 2017). Os picos IV e V representam a origem alóctone natural da MOD. 
Visando reduzir esse conjunto de dados apresentados a um pequeno número de fatores sem a perda de informação o que pode oferecer uma melhor compreensão da caracterização da matéria orgânica dissolvida, foi aplicada a estes dados, a técnica estatística multivariada, análise hierárquica de agrupamentos (do inglês, hierarchical cluster analysis - HCA), que tem sido frequentemente utilizada para estudos ambientais (ALVES et al., 2018; NNOROM et al., 2019).

A HCA permite a visualização de dados multidimensionais em duas ou três dimensões e a determinação de grupos de elementos (ou de amostras) com comportamentos semelhantes (HORTELLANI et al., 2008). A similaridade entre elas foi calculada com base nas distâncias euclidianas e o método de Ward foi utilizado para a geração dos grupos. 0 dendograma obtido a partir dos resultados encontrados está ilustrado na Figura 7.

Figura 7 - Dendograma dos dados autoescalonados das variáveis (absorbância em 254 e 436 nm, IF e COD) para as amostras analisadas: cálculo da distância euclidiana e método de ligação Ward's.

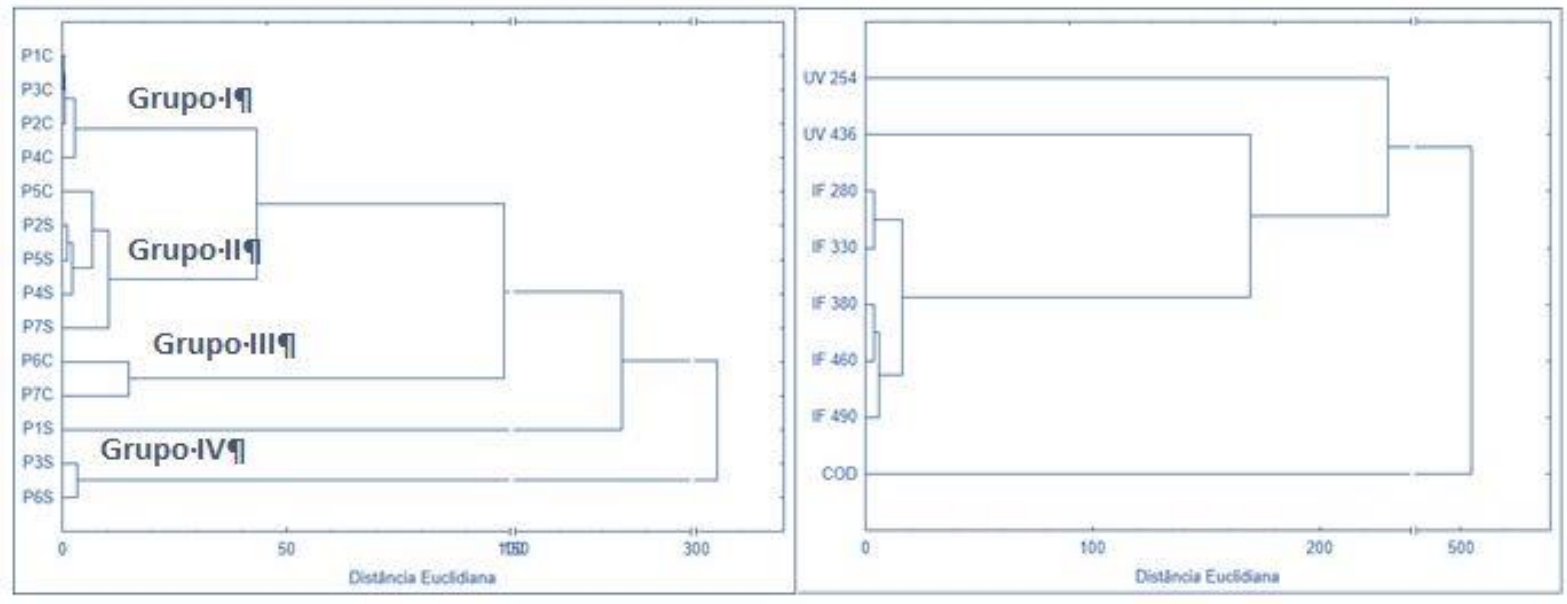

A partir da análise do dendograma representado na Figura 7, é possível observar o agrupamento das amostras em 4 grupos distintos, sugerindo que as amostras dos rios São Francisco (P1, P2, P3, P4 e P5) e Jacaré (P6 e P7) apresentam dissimilaridade entre si. 0 grupo I é constituído pelas amostras coletadas no rio São Francisco P1C, P2C, P3C e P4C e os baixos valores de absorbância em 254nm e em 436 nm apresentados por estas amostras, foi a principal razão da separação desse grupo.

O Grupo II também formado por amostras do rio São Francisco, são separadas do Grupo I por apresentar valores mais elevados de IF280 (P2S, P5C e P5S) IF320 (P4S) evidenciando o predomínio de uma matéria orgânica autóctone e de origem antropogênica, predominantemente.

As intensidades de fluorescências correspondentes aos picos III, IV e V foram os parâmetros mais importantes na separação do Grupo III dos demais, sendo composto apenas pelas amostras do rio Jacaré (P6C e P7C), estas amostras se separam das dos Grupos I e II por apresentar valores mais elevados de IF380, IF460 e IF490, evidenciando o predomínio de uma matéria orgânica alóctone, originária de fontes terrestres e/ou antropogênicas.

E por fim, o grupo IV está composto pelas amostras P3S e P6S que foram as mais sensíveis a variação sazonal para o parâmetro COD. O P3S teve nesse período um acréscimo de cerca de quatro vezes, enquanto que o P6S teve um decréscimo de duas vezes no valor da concentração do COD.

\section{CONCLUSÃO}

Os resultados obtidos neste trabalho foram suficientes para caracterizar e identificar as possíveis fontes de origem da matéria orgânica dissolvida presente nas águas superficiais dos rios São Francisco e Jacaré utilizando técnicas analíticas (UV-VIS e fluorescência molecular) rápidas, de fácil operação e de baixo custo. Ficou evidente a variação qualitativa e quantitativa na MOD entre o período seco e chuvoso, com forte contribuição de matéria orgânica natural, predominante autóctone, nas amostras do rio São 
Francisco no período chuvoso e de origem antropogênica no período seco principalmente nas amostras do rio Jacaré P6 (Calha do centro de Difusão) e P7 (Foz do Rio Jacaré), onde a urbanização e uso de ocupação do solo é crescente.

Neste sentido, os resultados apresentados pela avaliação estatística, através da HCA, que utilizou as informações registradas pelos métodos de análise de Intensidade de Fluorescência (IF) e UV-Vis, ratificam que o monitoramento da qualidade da MOD pode ser utilizada como um indicador natural de contaminação dos recursos hídricos, além de reforçar a importância da preservação e monitoramento dessas áreas que podem vir a ter a depreciação da qualidade de suas águas, tornando-as impróprias aos seus diversos usos.

\section{AGRADECIMENTOS}

Em nome do professor Dr. Antenor de Oliveira Aguiar Netto agradecemos a toda equipe do projeto Opará: águas do São Francisco, ao mesmo tempo em que agradecemos ao LTMA - professor Dr. Carlos Alexandre B. Garcia e ao PRORH (UFS) - professor Dr. Inajá F. de Sousa pela infraestrutura e as agências de fomento, CAPES (Coordenação de Aperfeiçoamento de Pessoal de Nível Superior) e CNPQ (Conselho Nacional de Desenvolvimento Científico e Tecnológico) pelo financiamento concedido.

\section{REFERÊNCIAS}

[1] AGUiAR NETTO, A.O. SANTANA, M.R.F. (2015). Contexto Socioambiental das Águas do Rio São Francisco. Editora UFS, São Cristóvão - SE, 342 p.

[2] APHA. American Public Health Association (2017). Standard Methods for the Examination of Water and Wastewater. 23a . ed.,Washington

[3] ALVES, J.P.H.; FONSECA, L.C.; CHIELLE, R.S.A.; MACEDO, L.C.B. (2018). "Monitoring water quality of the Sergipe river basin: na evaluation using multivariate data analysis".Brazilian Journal of Water Resources 23(27), pp. 112.

[4] ARGUELHO, M.L.P.M.; ALVES, J.P.H.; MONTEIRO, A.S.C.; GARCIA, C.A.B. (2017) "Characterization of dissolved organic matter in an urbanized estuary located in Northeastern Brazil". Environmental Monitoring and Assessment 189, pp. $272-284$.

[5] BRODER, T.; KNORR, K. H.; BIESTER, H. (2017).Changes in dissolved organic matter quality in a peatland and forest headwater stream as a function of seasonality and hydrologic conditions. Hydrology and Earth System Sciences, v. 21, n. 4, p. 2035-2051.

[6] CÉSAR, J.; AZEVEDO, R. (2008). ANÁLISE DE FLUORESCÊNCIA DE SUBSTÂNCIAS HÚMICAS EXTRAÍDAS DA ÁGUA, SOLO E SEDIMENTO DA LAGOA DOS PATOS- MS. v. 31, n. 6, p. 1324-1329.

[7] CETESB, Guia nacional de coleta e preservação de amostras: água, sedimento, comunidades aquáticas e efluentes líquidos. São Paulo: CETESB; Brasília: ANA, p.245, 2011.

[8] CHAPMAN, D.(1992), Water Quality Assessents : A guide to use of biota, sediments and water in environmental monitoring, Londres, UK, Chapman \& Hall Ltd, 584 p.

[9] CONAMA (Conselho Nacional de Meio Ambiente). Resolução n.ํ 357, de 17 de março de 2005. Dispõe sobre a classificação dos corpos de água e diretrizes ambientais para o seu enquadramento, bem como estabelece as condições e padrões de lançamento de efluentes, e dá outras providências. Brasília: Gráfica e Editora Itamarati, 2005.

[10] COSTA, P.R.S.M.; AGUIAR NETTO, A.O. (2018).Lugares, Potencialidades e Resistência: Terra e povo no São Francisco. Criação Editora, Aracaju - SE, 205 p.

[11] DUAN, S.; CHEN, N.; KAUSHAL, S. S.; CHIGBU, P.; ISHAQUE, A.; MAY, E.; OSEJI, O. F. (2015). Dynamics of dissolved organic carbon and total dissolved nitrogen in Maryland's coastal bays. Estuarine, Coastal and Shelf Science, v. 164, p. 451-462.

[12] FINDLAY, S. E. G.; PARR, T. B. (2017). Dissolved Organic Matter. Elsevier Inc.,v. 2, pp. 21 - 36.

[13] GATSELOU, V. A.; GIOKAS, D. L.; VLESSIDIS, A. G. (2014). Determination of dissolved organic matter based on UVlight induced reduction of ionic silver to metallic nanoparticles by humic and fulvic acids. Analytica Chimica Acta, v. 812 , p. 121-128.

[14] GUSSO P.K (2008). Caracterização fluorométrica da matéria orgânica dissolvida e sua relação autóctone/alóctone na baía de Paranaguá - Curitiba, Dissertação (Mestrado em Ecologia e Conservação) - Universidade Federal do Paraná, 106f.,. 
[15] HELMS, J. R.; STUBBINS, A.; RITCHIE, J. D.; MINOR, E. C.; DAVID, J.; MOPPER, K.; HELMS, R.; STUBBINS, A.; KIEBER, D. J. (2008). Absorption Spectral Slopes and Slope Ratio as indicators of molecular source, slopes and slope ratios Absorption spectral of chromophoric and photobleaching dissolved matter organic. American Society of Limnology and Oceanography, Inc. v. 53, n. 3, p. 955-969.

[16] HERZSPRUNG, P.; OSTERLOH, K.; TÜMPLING, W. VON; HARIR, M.; HERTKORN, N.; SCHMITT-KOPPLIN, P.; MEISSNER, R.; BERNSDORF, S.; FRIESE, K. (2017). Differences in DOM of rewetted and natural peatlands - Results from high-field FT-ICR-MS and bulk optical parameters. Science of the Total Environment, v. 586, p. 770-781.

[17] HORTELLANI, M. A.; SARKIS, J. E. S.; ABESSA, D. M. S.; SOUSA, E. C. P. M. (2008). “Avaliação da contaminação por elementos metálicos dos sedimentos do estuário Santos".Química Nova 31, pp. 10-19.

[18] HUDSON, N.; BAKER , A.; REYNOLDS, D.(2007) Fluorescence analysis of dissolved organic matter in natural, waste and polluted waters - a rewiew. River Research and Applications, v.23 (6), p. 631-649.

[19] Hur, J.; Lee, B.M. (2011). Characterization of binding site heterogeneity for copper within dissolved organic matter fractions using two-dimensional correlation fluorescence spectroscopy. Chemosphere, v. 83 (11), p. 1603 $-1611$.

[20] JAFFÉ, R.; BOYER, J.N.; LU, X.; MAIE, N.; YANG, C.; SCULLY, N. M.; MOCK, S. (2004).Source characterization of dissolved organic matter in a subtropical mangrove-dominated estuary by fluorescence analysis.Marine Chemistry, v. 84, p.195-210.

[21] KNAPIK, H. G.; FERNANDES, C. V. S.; AZEVEDO, J. C. R. DE; AMARAL PORTO, M. F. DO. (2014). Applicability of Fluorescence and Absorbance Spectroscopy to Estimate Organic Pollution in Rivers. Environmental Engineering Science, v. 31, n. 12, p. 653-663.

[22] KORSHIN, GV., LI, C. and BENJAMIN, MM. (1997). Monitoring the properties of natural organic matter through UV spectroscopy: a consistent theory. Water Research, vol. 31, no. 7, p. 1787-1795.

[23] MASSICOTTE, P.; ASMALA, E.; STEDMON, C.; MARKAGER, S. (2017). Global distribution of dissolved organic matter along the aquatic continuum: Across rivers, lakes and oceans. Science of the Total Environment, v. 609, p. 180-191.

[24] MASSOUD, M.A. (2012).Assessment of water quality along a recreational section of the Damour River in Lebanon using the water quality index.Springer Science, v. 184, p. 4151 - 4160.

[25] MCDONALD, S.; BISHOP, A. G.; PRENZELER, P. D. \& ROBARDS, K. (2004)Analytical chemistry freshwater humic substances. Analytical chemistry Acta, V.527, p. 105-124. REWIE.

[26] McKnight, D. M.; Boyer, E. W.;Westerhoff, P. K.; Doran, P. T.; Kulbe, T.; Anderson, D.T. (2001). Spectrofluorometric characterization of dissolved organic matter for indication of precursor organic material and aromaticity. Limnol. Oceanogr, v. 46 (1), p. 38 - 48.

[27] MONTEIRO, A. S. C.; PARAT, C.; ROSA, A. H.; PINHEIRO, J. P(2016). Towards field trace metal speciation using electroanalytical techniques and tangential ultrafiltration. Talanta, v. 152, p. 112-118.

[28] Nnorom, I.C., Ewuzie, U., Eze, S.O., (2019). Multivariate statistical approach and water quality assessment of natural springs and other drinking water sources in Southeastern Nigeria. Heliyon 5, e01123.

[29] OLIVEIRA, J. L.; BOROSKI, M.; AZEVEDO, J. C. R. \& NOZAKI, J. (2006).Spectroscopic investigation of humic substances in a tropical lake during a complete hydrological cycle.Acta hydrochimica et hydrobiologica, v. 34, p. $608-617$.

[30] PEURAVUORI,J.; KOIVIKKO,R.; PHLAJA, K. (2002). Characterization, differentiation and classification of aquatic humic matter separated with different sorbents: synchronous scanning fluoresnce spectroscopy. Water Research, Amsterdam, V.36, p 4552-4562.

[31] SANTOS, L. M.(2006). Dinâmica da matéria orgânica de destino de metais pesados em dois solos submetidos à adição de lodo de esgoto. Dissertação (Mestrado ciências - Química Analítica) - Instituto de Química de São Carlos, USP - São Paulo. 142f.

[32] SELBERG, A.; VIIK, M.; EHAPALU, K.; TENNO, T. (2011). Content and composition of natural organic matter in water of Lake Pitkjärv and mire feeding Kuke River (Estonia).Journal of Hydrology, v. 400, n. 1-2, p. 274-280.

[33] Wilson, H. F.; Xenopoulos, M.A. (2009). Effects of agricultural land use on the composition of fluvial dissolved organic matter. Nature Geoscience, v. 2, p. 37 - 41.

[34] XU, H.; GUO, L. (2017). Molecular size-dependent abundance and composition of dissolved organic matter in river, lake and sea waters.WaterResearch, v. 117, n. April, p. 115-126.I 


\section{Capítulo 9}

Modelagem hidrossedimentológica da bacia hidrográfica do rio Betume, Baixo São Francisco sergipano

Antenor de Oliveira Aguiar Netto

Ricardo David Castillo Salazar

Clayton Moura de Carvalho

Marcela de Luna Freire Duarte

Resumo: 0 uso adequado do solo e a cobertura vegetal está intimamente relacionada à conservação dos recursos hídricos como a preservação do meio ambiente. Uma importante ferramenta para a representação e compreensão do comportamento hidrológico de uma bacia é a modelagem. Nesse sentido, a partir do monitoramento quantitativo da vazão, se usou o modelo SWAT, com o qual se estudou a dinâmica hidrossedimentológica da bacia hidrográfica do rio Betume no Baixo São Francisco Sergipano, o modelo usa um banco de dados especializado da bacia, constituído de informações geográficas, pedológicas, hidrológicas e climáticas. Se realizaram 3 cenários em função do uso da terra simulando a produção de água e sedimentos. A modelagem demostrou que a dinâmica da bacia se baseia principalmente no fluxo de escoamento de base. Dos 3 cenários hipotéticos realizados, o cenário Reflorestação produziu a menor taxa de produção de água e sedimentos, e o cenário Agricultura apresentou as maiores taxas.

Palavras-chave: Recursos hídricos, bacia hidrográfica, modelagem hidrológica, swat. 


\section{INTRODUÇÃO}

O Brasil embora conte com abundantes recursos hídricos, a distribuição destes não é favorável (TUNDISI, 2003). 0 desenvolvimento promovido pela sociedade, tem feito alterações na natureza e no meio ambiente. Uma das consequências negativas são o uso e manejo do solo de forma inadequada nas atividades agrícolas podendo estas ocorrer em diferentes escalas (CARVALHO NETO et al., 2011; OLIVEIRA, 2014).

Para um bom planejamento, gerenciamento e uso dos recursos hídricos, torna-se essencial a utilização de modelos matemáticos que ajudem a rápida compreensão e tomada de decisão por parte dos órgãos gestores. Um desses modelos matemáticos é o SWAT (Soil and Water Assessment Tool), que permite uma grande flexibilidade na configuração de bacias hidrográficas. Este modelo foi desenvolvido para predizer o efeito de diferentes cenários de manejo na qualidade da água, produção de sedimentos e cargas de poluentes em bacia hidrográficas (NEITSCH et al., 2011). A bacia hidrográfica do rio Betume, vem sofrendo dificuldades de captação de água para abastecer o perímetro irrigado da zona, assim como problemas de contaminação pelo uso de agrotóxicos na crescente demanda das atividades agrícolas, a degradação das nascentes e do meio ambiente (SANTOS et al., 2015; BRITTO et al., 2015).

Nesse contexto, 0 presente trabalho estudou a dinâmica hidrossedimentológica da bacia hidrográfica do rio Betume a partir do monitoramento quantitativo, avaliando a produção da água e sedimentos usando a ferramenta de modelagem SWAT, simulando 3 cenários em função do uso da terra.

\section{MATERIAIS E METODOS}

A área de estudo compreende abacia hidrográfica do rio Betume, um dos tributários do rio São Francisco, localiza-se na região do Baixo do São Francisco, na zona leste do estado de Sergipe entre as coordenadas UTM 24L 720000, 770000 leste e 8820000, 8860000 sul com uma área de 849,94 km2 (Figura 1).

Figura 1 - Mapa de localização da bacia hidrográfica do rio Betume em Sergipe e no Brasil

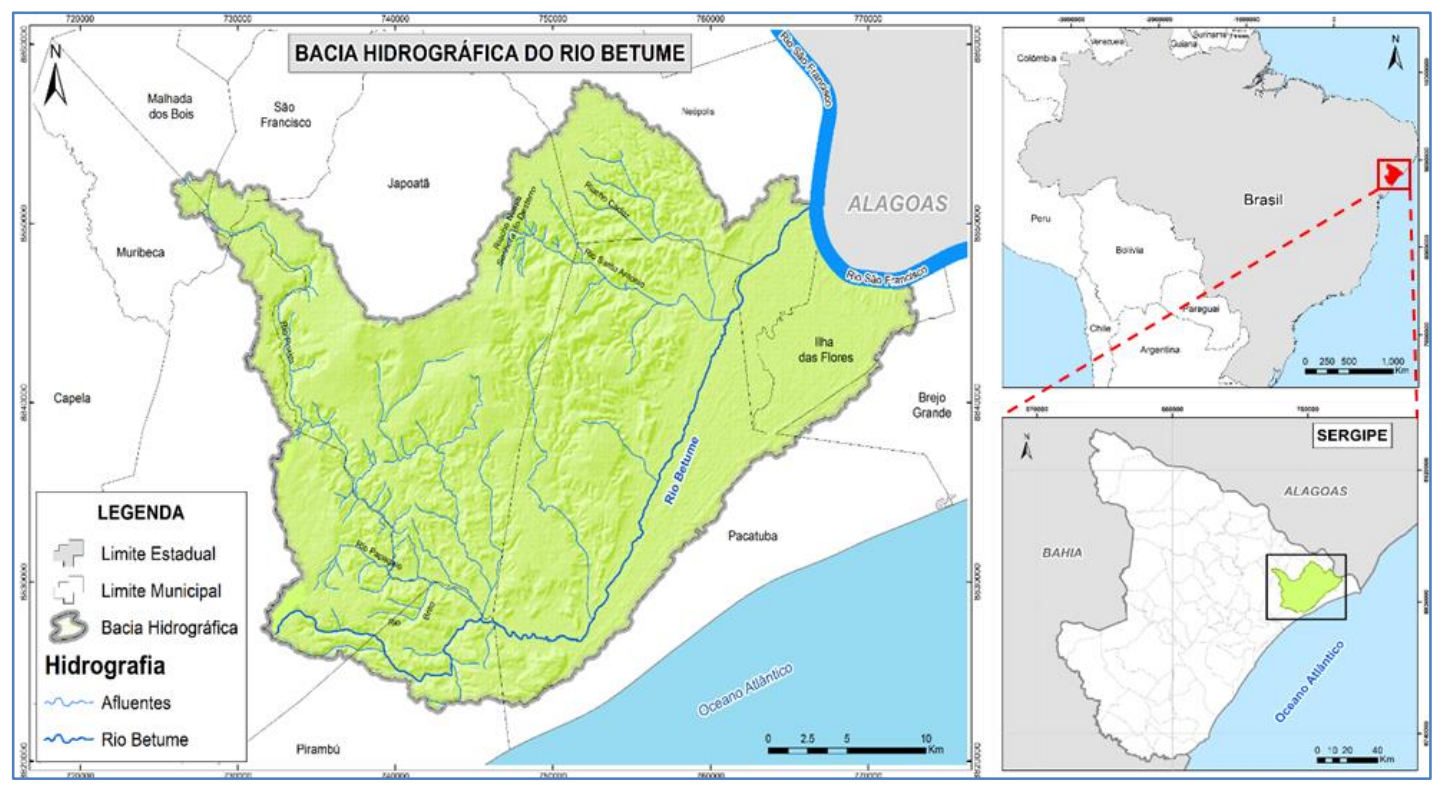

A temperatura média anual é de $25^{\circ} \mathrm{C}$ com evaporação de $1500 \mathrm{~mm}$ anuais. A precipitação média anual na região varia de 500 a $1300 \mathrm{~mm}$, caracterizado por um clima tropical semiúmido. Os solos predominantes na região são: Argissolo Vermelho Amarelo, Neossolo Quartzarrênicos, Neossolos, Planossolos e Espodossolos (EMBRAPA, 2006). A bacia hidrográfica do rio Betume se encontra inserida no bioma da Mata Atlántica. 0 rio Betume tem uma classificação 4 na ordem de Strhaler, coeficiente de compacidade 3,97 e vazão média anual 4,227 m3.s-1 (AGUIAR NETTO et al., 2011). 


\subsection{DADOS DE ENTRADA DO MODELO SWAT}

Para a simulação usando o modelo SWAT foram considerados os seguintes dados: Modelo Digital de Elevação (DEM), da Bacia Hidrográfica do Rio Betume, foi utilizada a folha SC.24-Z-B, elaborados e ajustados pelo Banco de Dados Geomorfométricos do Brasil (TOPODATA) em Sistema de Coordenadas Geográficas e Datum WGS84 com resolução de 30 metros.

A partir do DEM foi feito o delineamento da bacia hidrográfica do rio Betume, no sistema de projeção SIRGAS 2000 UTM, zona 24S. Se escolheram 5 pontos de amostragem para a analises do solo usando a metodologia estabelecida pela EMBRAPA (1997). As cartas de tipo de solo e uso das terras se obtiveram do atlas digital de recursos hídricos de Sergipe (SERGIPE,2014).

Os dados de vazão se obtiveram em dois pontos, um à jusante e outro à montante do rio Betume. À montante se realizou a batimetria de uma seção transversal do rio e depois se mensurou a velocidade da água por meio do molinete hidráulico digital marca Global Water. A vazão do rio em m3.s-1 (Q) foi obtida através da integração do produto da velocidade média do fluxo em m.s-1 (Vi) pela área abrangida em $\mathrm{m} 2$ (Ai) representada na Equação 1. Para determinar a área do rio, se dividiu a largura em segmentos com espaçamento de $1 \mathrm{~m}$ obtendo-se 8 seções (CARVALHO, 2008).

O ponto considerado na jusante do rio Betume, foi a estação fluviométrica código 49744000 (Latitude10:28:10, Longitude -36:37:41) da SEMARH, localizada no município de Pacatuba no povoado Alagamar, que se usou como exutório para a modelagem.

$$
\boldsymbol{Q}=\sum \boldsymbol{Q}_{\boldsymbol{i}}=\sum \boldsymbol{A}_{\boldsymbol{i}} \cdot \boldsymbol{V}_{\boldsymbol{i}}
$$

Os dados climáticos foram obtidos a partir das series históricas oferecidas nas estações meteorológicas convencionais em Propriá nas coordenadas UTM 24L 736626; 8870574 e Altitude: 19.92 m e Pão de Açúcar nas coordenadas 24L 672215; 8921824 e Altitude: $21 \mathrm{~m}$. Japaratuba nas coordenadas UTM 24L 724579; 8846893e Neópolis nas coordenadas 24L 762676; 8836453. Se usaram 16 anos de amostragem (1999 - 2014) de dados climáticos.

A partir dos dados apresentados anteriormente, realizou-se os passos de entrada dos mesmos na parametrização inicial do modelo SWAT (CARVALHO NETO et al., 2011; ARAGÃO et al., 2013; PERAZZOLI et al., 2013).

A análise de sensibilidade, calibração e validação dos parâmetros se realizou com o software SWAT-CUP, usado também por Lelis et al. (2012), Rouholahnejad et al. (2012), e Strauch et al. (2012). O método analisou as incertezas dos parâmetros com o fator-P, que é o porcentual de dados observados dentro de 95\% de previsão de incerteza (95PPU) (ABBASPOUR, 2012).

A análise de sensibilidade permite identificar os parâmetros mais sensíveis e que alteram a variável que se deseja calibrar no modelo, e serve como ajuda e guia para futuras pesquisas conforme sugerido por Baltokoski et al. (2010), e também Lelis et al. (2012). A análise determinou 7 parâmetros (Tabela 1), indicados como os mais sensíveis na simulação de vazões em diversos trabalhos (Van GRIENSVEN et al., 2006; STRAUCH et al, 2012; SILVA, 2013; OLIVEIRA, 2014).

Conforme Lelis et al. (2011) e também Oliveira (2014), finalizada a fasede análise, se calibra o modelo com os parâmetros identificados como os mais sensíveis, os dados usados para a calibração compreende o período 2012 a 2013 da estação da SEMARH. A aplicação do SWAT-CUP, seguiu a metodologia descrita por Abbaspour (2012), processo no qual vai se alterando o valor, levando em conta o limite superior e inferior, de um parâmetro por vez a cada simulação até encontrar valores estatísticos aceitáveis entre dados observados e dados simulados. 
Tabela 1 - Ordem de sensibilidade dos parâmetros para simulação de vazão da bacia hidrográfica do rio

\begin{tabular}{|c|c|c|c|}
\hline Parâmetro & Descrição & Ordem Sensibilidade & Processo \\
\hline ALPHA_BF & $\begin{array}{l}\text { Constante de recessão do escoamento de } \\
\text { base }\end{array}$ & 0,473 & Fluxo subterrâneo \\
\hline SOL_AWC & Capacidade de água disponível no solo & 0,532 & $\begin{array}{l}\text { Armazenamento, } \\
\text { escoamento base, } \\
\text { escoamento superficial }\end{array}$ \\
\hline GWQMN & $\begin{array}{l}\text { Profundidade limite de água no aquífero } \\
\text { raso para o escoamento de base }\end{array}$ & 0,593 & Fluxo subterrâneo \\
\hline GW_DELAY & Tempo de retardo do fluxo subterrâneo & 0,613 & Fluxo subterrâneo \\
\hline HRU_SLP & $\begin{array}{l}\text { Declividade media (influencia no fluxo } \\
\text { lateral e no tempo de concentração) }\end{array}$ & 0,801 & Declividade \\
\hline $\mathrm{CN} 2$ & $\begin{array}{c}\text { Número da curva na condição II de } \\
\text { umidade }\end{array}$ & 0,884 & Escoamento superficial \\
\hline CH_N2 & $\begin{array}{l}\text { Coeficiente de rugosidade de Manning (n) } \\
\text { para o canal principal }\end{array}$ & 0,954 & Escoamento superficial \\
\hline
\end{tabular}

Betume.

Para validar o modelo, os parâmetros já calibrados na etapa anterior, foram mantidos constantes. Nesta etapa se usaram os dados de vazão no período 2014 a 2015, realizando-se uma última simulação de vazões com o SWAT. Para avaliar o desempenho do modelo se usaram índices estatísticos conforme indica Moriasi et al. (2007).

Os cenários objetivaram-se em relação a problemática hídrica do perímetro irrigado do Betume e o desmatamento para favorecer a crescente agricultura da região.

Para simular os cenários se usou a metodologia adotada por Carvalho Netto et al. (2010) e Silva (2013), a qual consiste em modificar a curva número $(\mathrm{CN})$, ajustando o valor para diferentes usos da terra. Os cenarios considerados foram 3 :

CENARIO 1: Uso atual do solo na bacia hidrográfica do rio Betume, mantendo-se as práticas agrícolas atuais das áreas em uso. Com valor médio da curva número de 71,9

CENARIO 2: Cobertura vegetal nativa (Floresta mista), simulando uma reflorestação das áreas de uso agrícola. Para este cenário se usou CN igual a 55

CENARIO 3: O avanço das culturas predominantes (arroz, cana de açúcar e pastagem), simulando uma deflorestação ampliando o uso da área agrícola. Neste caso o valor da curva número foi de 77.

\section{RESULTADOS E DISCUSSÃO}

A análise de sensibilidade determinou que a variação dos parâmetros ALPHA_BF, GWQMN, GW_DELAY e SOL_AWC estão comprometidos com o fluxo subterrâneo e avaliam de forma direta a resposta da vazão subterrânea em função de recarga e nas camadas do solo. Já o parâmetro SOL_AWC, é um indicativo do teor de umidade disponível no solo, este índice é importante porque dependendo do valor se atinge a capacidade de campo, o excesso é drenado subterrânea e superficialmente. Aguiar Netto (1999) explica que em casos de solos permeáveis, como os solos da bacia do rio Betume, este fenômeno ocorre dois ou três dias após de uma chuva ou irrigação.

Nas Figuras 2 e 3 podem ser analisados os hidrograma observados e simulados, nas fases de calibração e validação do modelo SWAT. Na calibração pode-se observar que para a época seca, janeiro a março dos anos 2013 e 2014 superestimou levemente a vazão; já nos meses de setembro a dezembro de 2013, os valores de recessão foram levemente subestimados. Enquanto para a época chuvosa, nos meses de abril a agosto de 2013 o modelo subestimou levemente os picos de vazão, considerando satisfatório para o modelo. 
Figura 2 - Hidrograma da vazão mensal referente à calibração no período janeiro 2013 a março 2014

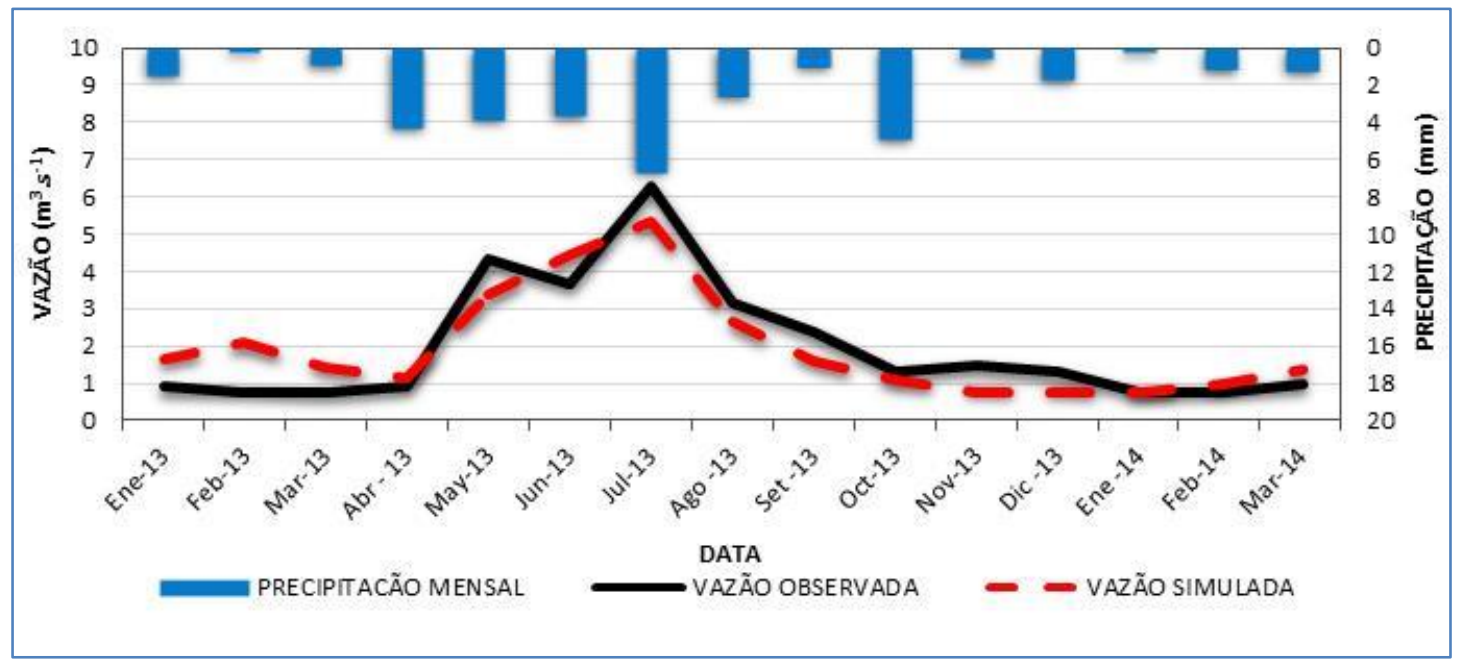

Figura 3 - Hidrograma de vazão mensal referente à validação abril 2014 a junho 2015

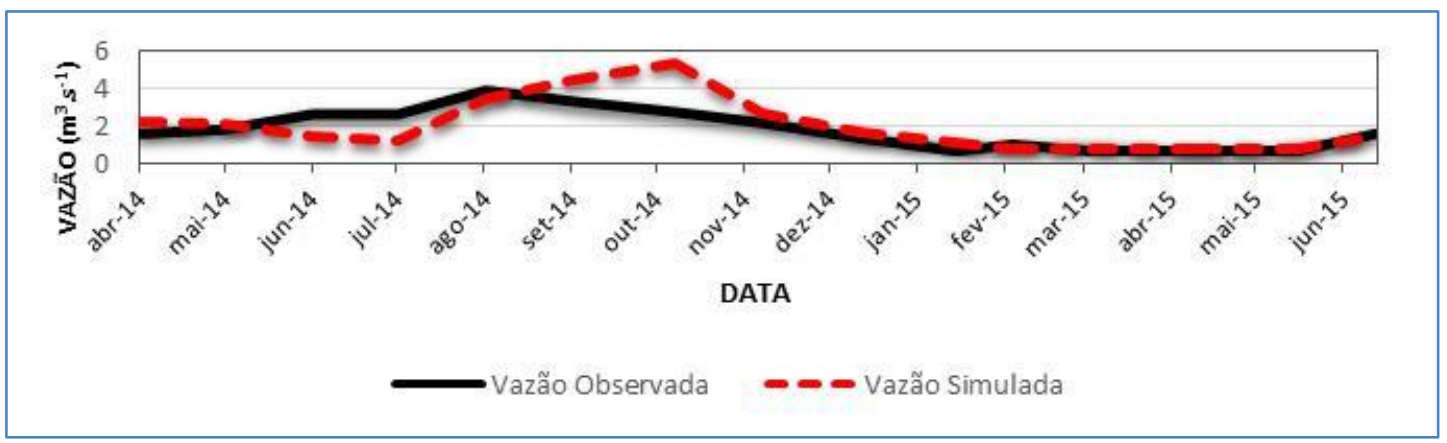

Esta simulação indica que o modelo é mais eficiente na simulação de vazões mínimas (ANDRADE et al., 2013).

Já para o período de validação o hidrograma mostra que os picos de vazão não coincidiram (Figura 3), mas houve uma tendência de melhor ajuste nas vazões mínimas, já para as vazões de picos maiores, foram superestimados. Segundo Krausse et al. (2005) a eficiência do modelo aumenta quando o escoamento superficial é muito baixo ou nulo, na qual os erros relacionados com baixos valores de vazões tendem a ser menores que aqueles associados com vazões maiores. Strauch et al. (2012) e Aragão et al. (2013) encontraram uma situação similar ondena validação a simulação foi melhor para vazões mínimas.

De acordo com os valores de desempenho proposta por Moriasi et al. (2007) e usados por muitos pesquisadores na análise de modelos hidrológicos como Machado et al. (2003); Lelis e Callijuri (2010); Aragão et al. (2013); Perazzoli e Souza (2013); e Oliveira (2014) entre outros, se usaram o NS, R2, PBIAS e RSR para testar a eficiência do SWAT na simulação do comportamento de vazão na bacia hidrográfica do rio Betume, como se mostra na Tabela 2.

Tabela 2 - Critérios de avaliação de desempenho de modelos hidrológicos e suas respectivas classificações

\begin{tabular}{|c|c|c|c|c|}
\hline Classificação & NS & RSR & PBIAS (vazão) & $\mathrm{R}^{2}$ \\
\hline Muito bom & $0,75<\mathrm{NS} \leq 1,00$ & $0,00 \leq \mathrm{RSR} \leq 0,50$ & PBIAS $< \pm 10$ & \\
\hline Bom & $0,65<\mathrm{NS} \leq 0,75$ & $0,50 \leq \mathrm{RSR} \leq 0,60$ & $\pm 10 \leq$ PBIAS $<15 \pm$ & \\
\hline Satisfatório & $0,50<\mathrm{NS} \leq 0,65$ & $0,60 \leq \mathrm{RSR} \leq 0,70$ & $\pm 15 \leq$ PBIAS $<25 \pm$ & $\mathrm{R}^{2}>0,50$ \\
\hline Insatisfatório & $\mathrm{NS} \leq 0,5$ & $\mathrm{RSR}>0,70$ & PBIAS $\geq \pm 25$ & \\
\hline
\end{tabular}


Os valores de desempenho na fase de calibração foram considerados muito bom, onde o coeficiente de Nash- Sutcliffe (NS) teve um valor de 0,80, o coeficiente de determinação (R2) de 0,81; o porcentual de tendência (PBIAS) de -1,3 e a raiz quadrada do erro quadrático médio (RSR) de 0,44. Para o período de validação os resultados referentes aos critérios estatísticos R2 $(0,55)$ e PBIAS $(-6,1)$ pode-se afirmar que o modelo conseguiu reproduzir o padrão do hidrograma; com o qual o modelo é capaz de descrever os processos hidrológicos da bacia hidrográfica do rio Betume.

Ressalta-se que a produção de sedimentos não foi calibrada por falta de dados, o qual não impede que se analise o estudo sobre sua variabilidade espacial, pois de acordo com os desenvolvedores do modelo SWAT, este foi feito também para ser aplicado em bacias não instrumentalizadas. (NEITSCH et al., 2011; UZEIKA et al., 2012), neste caso o estudo é utilizado para realizar inferências sobre as principais áreas produtoras de sedimentos em função ao uso do solo da bacia hidrográfica do rio Betume.

\subsection{CENÁRIOS}

Na Figura 4 são apresentados os mapas de produção de água e sedimentos para as sub bacias, referente ao período de 2002 a 2014 nos três cenários propostos: Cenario1- Uso atual, Cenário 2- Reflorestação e Cenário 3 - Agricultura. A produção de água no cenário 1 varia de 2,17 a 25,26 mm.ano-1. As sub bacias 5 e 11 apresentaram as menores produções de água entre 2,17 a 2,77 mm.ano-1. Observa-se que a sub bacia 5 apresenta uma área industrial de 47,7 ha, o uso do solo é floresta e agricultura; o que justifica os baixos valores simulados. As sub bacias 3 e 8apresentaram a maior produção de água entre 16,80 a 25,26 mm.ano-1. Em estas sub bacias o solo predominante é o Argissolos com cobertura vegetal de pastagem e pantanal sem floresta.

Figura 4 - Produção de água e sedimentos dos cenários 1, 2 e 3 na bacia hidrográfica do rio Betume.

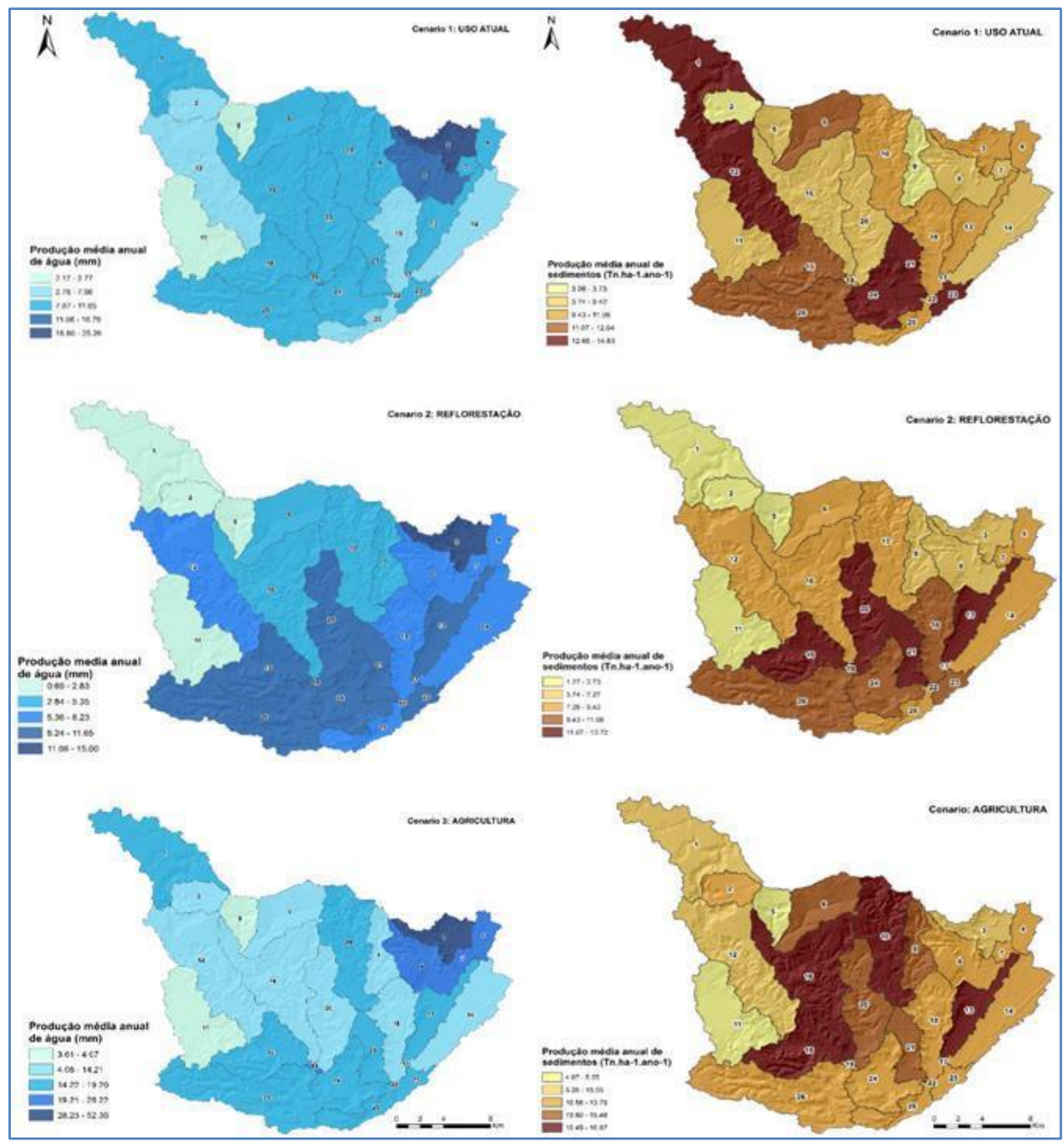


Para o cenário 2, a produção de água sofreu um decréscimo de $-26 \%$. Vários fatores contribuem para este resultado, dentre eles pode-se citar o menor valor da CN de 55 e o aumento da evapotranspiração que segundo Lino (2009), contribui para o menor escoamento superficial. Neste cenário a produção média anual de água considerou valores compreendidos entre 0,69 e 15,00 mm.ano-1. As sub bacias 1, 2, 5 e 11 apresentaram os valores mais baixos de produção, entre 0,69 a 2,83 mm.ano-1, em quanto a sub bacia 3 continuo sendo a maior produtora de água (15,00 mm.ano-1). Neste cenário as sub bacias 13, 15, 19, 20, 21, 23, e 24 com solos Planossolos e Espodossolos com áreas embrejadas, apresentaram uma produção de água maior a 8,24 mm.ano-1.

Lelis (2011) encontrou uma redução na produção de escoamento superficial e sedimentos quando substituiu 15\% da pastagem pelo uso floresta, enquanto substituindo da área de floresta por pastagem em $25 \%$ houve um aumento na produção de sedimento e um decréscimo na produção de escoamento superficial. Carvalho Netto et al. (2011) simulando cenários usando vegetação nativa frente algaroba e um valor CN de 77 em ambos casos, o escoamento superficial foi maior no cenário de vegetação nativa.

No cenário 3, a produção média anual de água se acrescentou 70\% com relação ao cenário 1 . As sub bacias 5 e 11 foram novamente as que apresentaram os valores mais baixos de produção $(<4,07$ mm.ano-1). A sub bacia 26 onde se localiza a principal nascente do rio Betume, apresentou uma produção média anual de água entre 14,22 a 19,20 mm.ano-1.

O cuidado e manutenção de florestas promove modificações nas propriedades do solo como o aumento da condutividade hidráulica do solo, redução da densidade, aumento da capacidade de armazenamento de água, os quais contribuem para o aumento da disponibilidade hídrica média ao longo do tempo (BLAINSKI et al., 2011).

A produção de sedimentos na bacia hidrográfica do rio Betume apresentou uma maior variação com a mudança do uso da terra a partir dos cenários simulados, em comparação com a produção de água (Figura 4)

No cenário 1 pode-se observar que a maior taxa de produção de sedimentos se concentra nas sub bacias 1 , $12,21,23$ e 24 com valores de 12,65 a 14,63 ton.ha-1.ano-1. Estas se caracterizam por possuírem grandes áreas de solos tipo Argissolos e Neossolos e em sua maioria são usadas para cultivos agrícolas e pastagem. As sub bacias 2 e 9 foram as que apresentaram menores valores de produção de sedimentos $(<3,73$ ton.ha-1.ano-1) observasse que nestas sub bacias apresentam quase um $15 \%$ de floresta, o solo predominante é o Neossolos Quartzarenicos, que são solos com alta capacidade de infiltração, reduzindo o carreamento de sedimentos (SILVA, 2013).

O cenário 2 apresentou menor produção de sedimentos em relação aos cenários 1 e 3 em -15,81 \% (1,64 ton.ha-1) e -46,96 \% (4,1 ton.ha-1) respectivamente. Corroborando estes resultados com os estudos realizados por Carvalho Netto et al. (2010), Silva (2013), e Perazzoli et al. (2013) onde foi constatado que a menor perda de solo foi na simulação de cenários alternativos, quando o uso da terra foi substituído por florestas. No mesmo modo estes autores ressaltaram que as maiores perdas do solo estão relacionadas à agricultura.

A diferença entre o cenário 2 com os cenários 1 e 3, é que um solo recoberto com florestas atua como barreira aos sedimentos, protegendo ao solo da erosão das chuvas e o vento. Dessa forma as florestas funcionam como um filtro de produção de sedimentos e outros sólidos em suspensão do escoamento superficial, diminuindo assim, os processos erosivos e consequentemente a produção de sedimentos (MACHADO et al., 2003; PINTO, 2011).

O cenário 3 apresenta a taxa de produção de sedimentos mais alta, quando comparadas com o cenário 1 mostraram um acréscimo de $23,7 \%$ e com o cenário 2 de 46,9\% na produção; apresentando valores de 4,87 a 16,67 ton.ha-1.ano-1. As maiores perdas de solo foram observadas nas sub bacias 10, 13, 15 e 16 com valores de 13,80 a 15,48 ton.ha-1ano-1. Estas tem como solos predominantes os Neossolos Quartzarrênicos e Planossolos.

Perazzoli et al. (2013) comenta que as atividades agrícolas alteram a proteção dos solos, deixando-o susceptível a ação do impacto da chuva e ao escoamento superficial, bem como pode promover a desestruturação da camada superficial do solo, justificando assim os resultados dos valores mais elevados neste cenário.

De forma geral, nos cenários apresentados, os resultados mostram que a perda de solos que se ocasiona na bacia é devido à erosão e modificações na estrutura dos solos principalmente por ações antrópicas, modificando a qualidade e quantidade da água. 


\section{CONCLUSÕES}

O modelo SWAT, consegui representar de forma satisfatória a simulação de vazão mensal na bacia hidrográfica do rio Betume.

A dinâmica hidrossedimentológica da bacia hidrográfica do rio Betume se baseia principalmente no fluxo de escoamento de base.

O cenário reflorestação apresentou a menor produção média anual de água e sedimentos, e o cenário agricultura apresentou o maior valor médio anual.

\section{REFERÊNCIAS}

[1] ABBASPOUR, K. C. (2012) SWAT-CUP: SWAT Calibration and Uncertainty Programs - A User Manual. 103 p.

[2] AGUIAR NETTO, A. O.; NACIF, P. G. S.; REZENDE, J. O. (1999) Avaliação do conceito de capacidade de campo para um latossolo amarelo coeso do estado da Bahia. Revista Brasileira Ciência e Solo, v. 23, n. 3, p. 661-667.

[3] AGUiAR NETTO, A. 0; LUCAS, A. A. T; SANTOS, A. G; ALMEIDA, C. A. (2011) Água e ambiente no Baixo São Francisco Sergipano. In: AGUIAR NETTO, A. O; LUCAS, A. A. T. Águas do São Francisco. São Cristóvão: Editora UFS, $312 \mathrm{p}$.

[4] AGUIAR NETTO, A. O.; SANTANA, N. R. F. (2015) Contexto socioambiental das águas do rio São Francisco. 1. Ed. São Cristóvão: UFS, 341p.

[5] ARAGÃO, R.; CRUZ, M. A. S.; AMORIM, J. R. A.; MENDONÇA, L. C.; FIGUEIREDO, E. E.; SRINIVASAM, V. S. (2013) Análise de sensibilidade dos parâmetros do modelo SWAT e simulação dos processos hidrossedimentológicos em uma bacia no agreste nordestino. Revista Brasileira Ciência e Solo, v. 37, n. 4, p. 1091-1102.

[6] BRITTO, F. B.; SILVA, T. M. M.; VASCO, A. N.; AGUIAR NETTO, A. O.; CARVALHO, C. M. (2015) Avaliação do risco de contaminação hídrica por agrotóxicos no perímetro irrigado Betume no Baixo Rio São Francisco. Revista Brasileira de Agricultura Irrigada. v. 9, n. 3, p. 158-170.

[7] BALTOKOSKI, V.; TAVARES, M. H. F.; MACHADO, E. R.; OLIVEIRA, M. P. (2010) Calibração de modelo para a simulação de vazão e de fósforo total nas sub- bacias dos rios Conrado e Pinheiro - Pato Branco (PR). Revista Brasileira de Ciência do Solo, v. 34, n. 1, p.253-261.

[8] BLAINSKI, E.; ARAUJO, I.; GOMES, P. (2011) Modelagem e simulação do uso do solo e as alterações no ambiente. In: CONGRESSO BRASILERIO DE CIENCIA DO SOLO, 23., Uberlandia. Anais... , Uberlandia: SBCS, 2011.

[9] CARVAlHO, T. M. (2008) Técnicas de medição de vazão por meios convencionais e não convencionais. Revista Brasileira de Geografia Física, v. 1, n. 1, p. 73-85.

[10] CARVALHO NETO, J. G; SRINIVASAN, V. S.; RUFINO, I. A. A. (2011) Aplicação do modelo SWAT para estudo de cenários hipotéticos na bacia hidrográfica do riacho dos namorados no Cariri Paraibano. Revista Geográfica Acadêmica, v. 5, n.1, p. 48-58.

[11] EMBRAPA - Empresa Brasileira De Pesquisa Agropecuária. Centro Nacional de Pesquisa de Solos. (1997) Manual de métodos e análise de solo. Rio de Janeiro. 212p. (EMBRAPA-CNPS. Documento, 1).

[12] EMBRAPA - Empresa Brasileira De Pesquisa Agropecuária. (2006). Sistema brasileiro de classificação de solos. Rio de Janeiro: Embrapa Solos, 306p.

[13] GREEN, C. H.; VAN GRIENSVEN, A. (2008) Autocalibration in hydrologic modeling: Using SWAT2005 in smallscale watersheds. Environmental Modelling \& Software, v. 23, p. 422-434.

[14] LELIS, T. A.; CALIJURI, M. L.; SANTIAGO, A. F.; LIMA, D .C.; ROCHA, E. O. (2012). Análise de sensibilidade e calibração do modelo SWAT aplicado em bacia hidrográfica da região sudeste do Brasil. Revista Brasileira de Ciência do Solo, v. 36, p. 623-634.

[15] MACHADO, R. E.; VETTORAZZI, C. A.; XAVIER, A. C. (2003) Simulação de cenários alternativos de uso da terra em uma microbacia utilizando técnicas de modelagem e geoprocessamento. Revista Brasileira Ciência e Solo. v. 27, p. 727-733.

[16] MORIASI, D. N.; ARNOLD, J. G.; VAN LIEW, M. W.; BINGER R. L.; HARMEL R. D.; VEITH, T. (2007) Model evaluation guidelines for systematic quantification of accuracy in watershed simulations. American Society of Agricultural and Biological Engineers, v. 50, n. 3, p. 885-900, 2007.

[17] NEITSCH, S. L., ARNOLD, J. G., KINIRY, J. R., WILLIAMS, J. R. (2011) Soil and Water Assessment Tool Theoretical Documentation Version 2009 (Portuguese). Grassland, Soil and Water Research Laboratory; Agricultural Research Service; USA. 
[18] OLIVEIRA, L. T. (2014) Aplicação do modelo SWAT para similar vazões em uma bacia hidrográfica em Aracruz, ES. Jerónimo Monteiro: UFES. 162p. Dissertação.

[19] PERAZZOLI, M; PINHEIRO, A; KAUFMANN, V. (2013) Efeitos de cenários de uso do solo sobre o regime hídrico e produção de sedimentos na bacia do Ribeirão Concórdia - SC. Revista Árvore, v. 37, n. 5, p. 859-869.

[20] ROUHOLAHNEJAD, E.; ABBASPOUR, K. C.; VEJDANI, M.; SRINIVASAN, R.; SCHULIN, R.; LEHMANN, A. (2012) A parallelization framework for calibration of hydrological models. Environmental Modelling e Software, v. 31, p. 28-36.

[21] SANTOS, H. B., BARRETO, M. C., FACCIOLI, G. G. (2015) Qualidade da água de drenagem em reuso direto no perímetro irrigado Betume-SE. In: AGUIAR NETTO, A. O; SANTANA, N. R. Contexto socioambiental das águas do rio São Francisco. São Cristóvão: Editora UFS, 342p.

[22] SILVA, M. G. (2013) Modelagem ambiental na bacia hidrográfica do rio Poxim-Açu/SE e suas relações antrópicas. Tese (Doutorado em desenvolvimento e meio ambiente) - Universidade Federal de Sergipe, 224 p.

[23] SERGIPE. SEMARH - Secretaria de Estado do Meio Ambiente e dos Recursos Hídricos. (2014) Atlas digital sobre recursos hídricos de Sergipe. SRH/SIRHSE: Sergipe.

[24] STRAUCH, M.; BERNHOFER, C.; KOIDE, S.; VOLK, M.; LORZ, C.; MAKESCHIN, F. (2012) Using precipitation data ensemble for uncertainty analysis in SWAT stream flow simulation. Jounal of Hydrology, v. 414-415, p.413-424.

[25] UZEIKA, T. (2012) Use of the SWAT model for hydro-sedimentologic simulation in a small rural watershed. Revista Brasileira de Ciência do Solo, v. 36, p. 557-565.

[26] VAN GRIENSVEN, A.; MEIXNER, T.; GRUNWALD, S.; BISHOP, T.; DILUZIO, M.; SRINIVASAN, R. (2006). A global sensitivity analysis tool for the parameters of multi-variable catchment models. Journal of Hydrology, v. 324, p. 10-23, 2006. 
